Portland State University

PDXScholar

\title{
Monomeric and Polymeric Fluoroalkyl Sulfonyl Fluorides, Sulfonate Salts and Sulfonic Acids for Use as Electrolytes and Coatings
}

Nicolas Noel Hamel

Portland State University

Follow this and additional works at: https://pdxscholar.library.pdx.edu/open_access_etds

Part of the Environmental Sciences Commons

Let us know how access to this document benefits you.

\section{Recommended Citation}

Hamel, Nicolas Noel, "Monomeric and Polymeric Fluoroalkyl Sulfonyl Fluorides, Sulfonate Salts and Sulfonic Acids for Use as Electrolytes and Coatings" (1995). Dissertations and Theses. Paper 1265. https://doi.org/10.15760/etd.1264

This Dissertation is brought to you for free and open access. It has been accepted for inclusion in Dissertations and Theses by an authorized administrator of PDXScholar. Please contact us if we can make this document more accessible: pdxscholar@pdx.edu. 
MONOMERIC AND POLYMERIC FLUOROALKYL SULFONYL FLUORIDES, SULFONATE SALTS AND SULFONIC ACIDS

FOR UEE AS ELECTROLYTES AND COATINGS

by

NICOLAS NOEL HAMEL

A dissertation submitted in partial fulfillment of the requirements for the degree of

DOCTOR OF PHILOSOPHY

in

ENVIRONMENTAL SCIENCES AND RESOURCES: CHEMISTRY

Portland State University

1995 
UMI Number: 9530965

UMI Microform 9530965

Copyright 1995, by UMI Company. All rights reserved.

This microform edition is protected against unauthorized copying under Title 17, United States code.

\section{UMI}

300 North Zeeb Road

Ann Arbor, MI 48103 


\section{DISSERTATION APPROVAL}

The abstract and dissertation of Nicolas Noel Hamel for the Doctor of Philosophy in Environmental Sciences and

Resources: Chemistry were presented on January 20, 1995, and accepted by the dissertation committee and doctoral program. COMMITTEE APPROVALS:
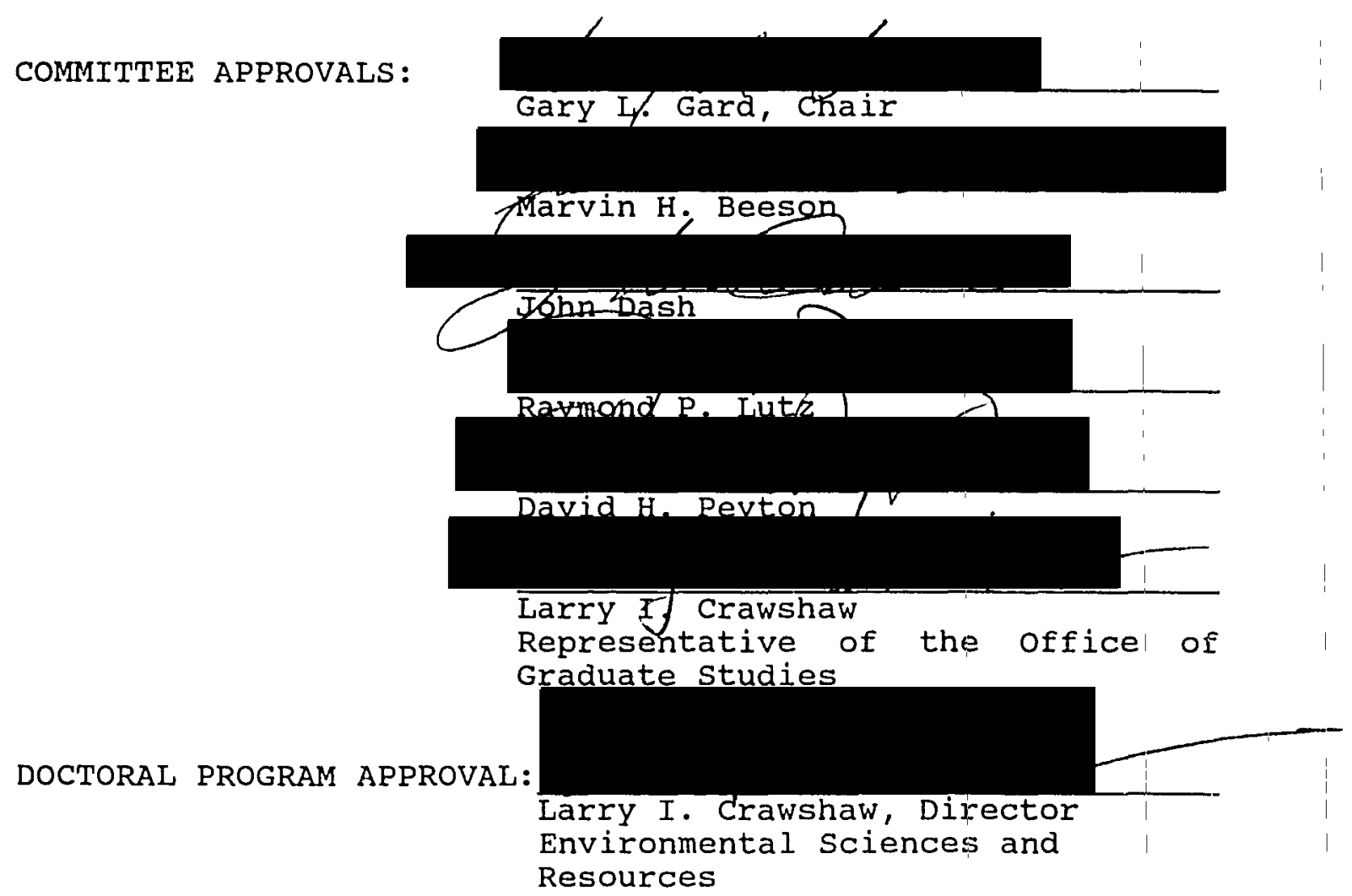

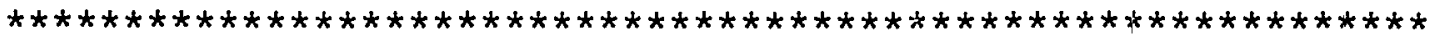

ACCEPTED FOR PORTLAND STATE UNIVERSITY BY THE LIBRARY

by

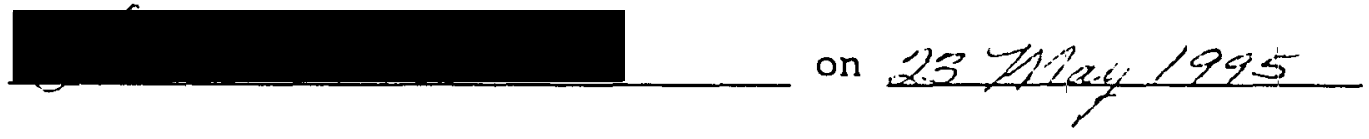




\section{ABSTRACT}

An abstract of the dissertation of Nicolas Noel Hamel for the Doctor of Philosophy in Environmental Sciences and Resources: Chemistry presented on January 20, 1995.

Title: Monomeric and Polymeric Fluoroalkyl Sulfonyl Fluorides, Sulfonate Salts and Sulfonic Acids for Use as Electrolytes and coatings

Monomeric and polymeric fluoroalkyl sulfonyl fluorides, sulfonate salts and sulfonic acids have qualities desirable for use as electrolytes in alternative energy sources such as fuel cells and solid polymer electrolyte lithium batteries. Since the nature of the fluoroalkyl group affects the properties of these compounds, new monomeric and polymeric fluoroalkyl sulfonyl fluorides, sulfonate salts and sulfonic acids were prepared in this work.

Simple compounds prepared in this work were: the fluoroalkyl sulfonyl fluorides, sulfonate salts and sulfonic acid $\mathrm{CHF}\left(\mathrm{OCF}_{2} \mathrm{CF}_{2} \mathrm{SO}_{2} \mathrm{~F}\right)_{2}, \mathrm{CF}_{2}\left(\mathrm{OCF}_{2} \mathrm{CF}_{2} \mathrm{SO}_{2} \mathrm{~F}\right)_{2}$, $\mathrm{CH}_{2}\left(\mathrm{OCF}_{2} \mathrm{CF}_{2} \mathrm{SO}_{3} \mathrm{Na}\right)_{2}, \mathrm{CF}_{2}\left(\mathrm{OCF}_{2} \mathrm{CF}_{2} \mathrm{SO}_{3}\right)_{2} \mathrm{Ca}, \mathrm{CF}_{2}\left(\mathrm{OCF}_{2} \mathrm{CF}_{2} \mathrm{SO}_{3} \mathrm{H}\right)_{2}$, prepared by means of electrochemical fluorination; $\mathrm{FC}\left(\mathrm{CF}_{3}\right)_{2} \mathrm{OCH}_{2} \mathrm{CH}_{2} \mathrm{OCF}_{2} \mathrm{CF}_{2} \mathrm{SO}_{2} \mathrm{~F}$ prepared using the adduct of hexafluoroacetone and silver fluoride; $\mathrm{CH}_{3} \mathrm{OCF}_{2} \mathrm{CF}_{2} \mathrm{SO}_{2} \mathrm{~F}$ prepared 
as a substrate for free-radical substitution reactions of fluorinated species; and the pentafluorosulfur lithium sulfonate salts $\mathrm{SF}_{5} \mathrm{CHFSO}_{3} \mathrm{Li}$ and $\mathrm{SF}_{5} \mathrm{CF}_{2} \mathrm{SO}_{3} \mathrm{Li}$.

Novel compounds containing both alcohol and fluoroalkyl sulfonyl functional groups were prepared: the chlorohydrin $\mathrm{ClCH}_{2} \mathrm{CH}(\mathrm{OH}) \mathrm{CH}_{2} \mathrm{OCF}_{2} \mathrm{CF}_{2} \mathrm{SO}_{2} \mathrm{~F}$; the benzyl ethers $\mathrm{HOCH}_{2} \mathrm{CH}\left(\mathrm{OCH}_{2} \mathrm{C}_{6} \mathrm{H}_{5}\right) \mathrm{CH}_{2} \mathrm{OCF}_{2} \mathrm{CF}_{2} \mathrm{SO}_{2} \mathrm{~F}$ and $\mathrm{C}_{6} \mathrm{H}_{5} \mathrm{CH}_{2} \mathrm{OCH}_{2} \mathrm{CH}(\mathrm{OH}) \mathrm{CH}_{2} \mathrm{OCF}_{2} \mathrm{CF}_{2} \mathrm{SO}_{2} \mathrm{~F}$ as a product mixture; and the diol $\mathrm{HOCH}_{2} \mathrm{CH}(\mathrm{OH}) \mathrm{CH}_{2} \mathrm{OCF}_{2} \mathrm{CF}_{2} \mathrm{SO}_{2} \mathrm{~F}$.

The diol was found to be a useful synthon for the preparation of two polymeric fluoroalkyl sulfonyl fluorides: the polyester $\left[\mathrm{C}(\mathrm{O}) \mathrm{CF}_{2} \mathrm{CF}_{2} \mathrm{CF}_{2} \mathrm{C}(\mathrm{O}) \mathrm{OCH}_{2} \mathrm{CH}\left(\mathrm{CH}_{2} \mathrm{OCF} \mathrm{CF}_{2} \mathrm{SO}_{2} \mathrm{~F}\right) \mathrm{O}\right] \mathrm{n}$ by reaction with perfluoroglutaric anhydride and a polyurethane formed with 1,6-diisocyanohexane. Other polymeric compounds prepared were: the sulfonyl fluoride, sulfonate salt and sulfonic acid $\left[\mathrm{OCH}_{2} \mathrm{CH}\left(\mathrm{CH}_{2} \mathrm{OCF}_{2} \mathrm{CF}_{2} \mathrm{SO}_{2} \mathrm{~F}\right)\right] \Omega$, $\left[\mathrm{OCH}_{2} \mathrm{CH}\left(\mathrm{CH}_{2} \mathrm{OCF}_{2} \mathrm{CF}_{2} \mathrm{SO}_{3} \mathrm{Na}\right)\right] n$ and $\left[\mathrm{OCH}_{2} \mathrm{CH}\left(\mathrm{CH}_{2} \mathrm{OCF}_{2} \mathrm{CF}_{2} \mathrm{SO}_{3} \mathrm{H}\right)\right] n$ prepared by homopolymerization of the epoxide $\mathrm{OCH}_{2} \mathrm{CHCH}_{2} \mathrm{OCF}_{2} \mathrm{CF}_{2} \mathrm{SO}_{2} \mathrm{~F}$; a cross-linked copolymer of the same epoxide; and the fluoroalkyl sulfonyl fluoride polyacrylate $\left[-\mathrm{CH}_{2}-\mathrm{CH}-\left(\mathrm{CO}_{2} \mathrm{CH}_{2} \mathrm{CH}_{2} \mathrm{CF}_{2} \mathrm{CF}_{2} \mathrm{OCF}_{2} \mathrm{CF}_{2} \mathrm{SO}_{2} \mathrm{~F}\right)\right] n$ prepared from the acrylate ester $\mathrm{H}_{2} \mathrm{C}=\mathrm{CHC}(\mathrm{O}) \mathrm{OCH}_{2} \mathrm{CH}_{2} \mathrm{CF}_{2} \mathrm{CF}_{2} \mathrm{OCF}_{2} \mathrm{CF}_{2} \mathrm{SO}_{2} \mathrm{~F}$.

${ }^{1} \mathrm{H},{ }^{19} \mathrm{~F}$ and ${ }^{13} \mathrm{C}$ nuclear magnetic resonance spectroscopy, infrared spectroscopy, mass spectrometry, melting point or boiling point, elemental analysis, contact angles, optical clarity, refractive index, and specific conductivity were 
among the techniques used to characterize the compounds. 
DEDICATION

Dedicated to my family.

Their patience and understanding made this possible. 


\section{ACKNOWLEDGEMENTS}

I would like to express my appreciation to all those at Portland State University who made this work possible: Dr. Gary L. Gard for providing guidance, resources and unending patience; Dr. Wolf Winter and Dr. Javid Mohtasham for insights to laboratory techniques; and Dr. David H. Peyton and those in his group for obtaining many excellent NMR spectra. Also, I would like to thank Dr. Raymond P. Lutz, Dr. Alfred S. Levinson and Dr. Carl C. Wamser for their discussions concerning reactions which didn't initially seem to make sense.

Many rewarding hours were spent in, or developing experiments for, the teaching laboratories. I again thank Doctors Lutz, Levinson and Wamser along with Dr. Horace F. White and Dr. William G. Becker for the opportunity to develop skills in these areas. 
TABLE OF CONTENTS

PAGE

ACKNOWLEDGEMENTS . . . . . . . . . . . . . . . . . . iii

LIST OF TABLES • • • • • • • • • • • • • • • • • • • • vi

LIST OF FIGURES. . . . . . . . . . . . . . . . . . . i ix

CHAPTER

I INTRODUCTION . • . . . . . . . . . . . . 1

II REVIEW OF POLYMERIC FLUOROALKYL

SULFONYL FLUORIDES AND DERIVATIVES • • • • • 11

Commercially Available Fluoroalkyl

sulfonate ionomers, derivatives

and Precursors . . . . . . . . . 12

other Fluoro-olefin and Vinyl Ether

Polymers and Copolymers . . . . . . 17

other Routes to Polymers with

Fluoroalkyl sulfonyl Fluoride

Groups or Derivatives . . . . . . . 23

III EXPERIMENTAL METHODS • • • • • . • • . 27

IV SIMPLE SULFONYL FLUORIDES, SULFONATE SALTS

AND SULFONIC ACIDS • • • • • • • . • • • • • 33

Increasing Fluorine content . . . . 33

Electrochemical Fluorination . . 34

Reactions with Fluorinated

Species . . . . . . . . . . . 41

$\mathrm{SF}_{5}$ Containing Salts . . . . . . . 47

Experimental • . . . . . . . . 52 
V REACTIVE INTERMEDIATES AND

POLYMERIC COMPOUNDS . . . . . . . . . . 65

Ring-opening Reactions

of Epoxides . . . . . . . . . . 66

Fluoroalkyl Acrylate Esters . . 68

Ring-opening Reactions of

$\mathrm{OCH}_{2} \mathrm{CHCH}_{2} \mathrm{OCF}_{2} \mathrm{CF}_{2} \mathrm{SO}_{2} \mathrm{~F}$. . . . . . . . . 69

Fluoroalkyl Acrylate Ester

$\mathrm{CH}_{2}=\mathrm{CHC}(\mathrm{O}) \mathrm{OCH}_{2} \mathrm{CH}_{2} \mathrm{CF}_{2} \mathrm{CF}_{2} \mathrm{OCF}_{2} \mathrm{CF}_{2} \mathrm{SO}_{2} \mathrm{~F}$. . . 79

Polymeric Compounds . . . . . . . . 84

Polymerization of Epoxides . . . 84

Polyesters . . . . . . . . 87

Polyurethanes . . . . . . . . 89

Polyacrylates . . . . . . . 92

Polymerization Reactions Involving

$\mathrm{OCH}_{2} \mathrm{CHCH}_{2} \mathrm{OCF}_{2} \mathrm{CF}_{2} \mathrm{SO}_{2} \mathrm{~F}$. . . . . . . . . . 94

Polymerization Reactions Involving

$\mathrm{HOCH}_{2} \mathrm{CH}(\mathrm{OH}) \mathrm{CH}_{2} \mathrm{OCF}_{2} \mathrm{CF}_{2} \mathrm{SO}_{2} \mathrm{~F}$. . . . . . 99

Polymerization of

$\mathrm{CH}_{2}=\mathrm{CHC}(\mathrm{O}) \mathrm{OCH}_{2} \mathrm{CH}_{2} \mathrm{CF}_{2} \mathrm{CF}_{2} \mathrm{OCF}_{2} \mathrm{CF}_{2} \mathrm{SO}_{2} \mathrm{~F}$. . . . 102

Experimental . . . . . . . . 105

VI CONCLUSIONS • . . . • . . . . . . . . . 120

REFERENCES • . . . . . . . . . . . . . . . . . . 123

APPENDIX

INFRARED SPECTRA • • • • . . . • . . . . • . 129 
I ${ }^{19} \mathrm{~F}$ and ${ }^{1} \mathrm{H}$ NMR Data for Compounds $\mathrm{CHF}\left(\mathrm{OCF}_{2} \mathrm{CF}_{2} \mathrm{SO}_{2} \mathrm{~F}\right)_{2}$ (II), $\mathrm{CF}_{2}\left(\mathrm{OCF}_{2} \mathrm{CF}_{2} \mathrm{SO}_{2} \mathrm{~F}\right)_{2}$ (III), $\mathrm{CH}_{2}\left(\mathrm{OCF}_{2} \mathrm{CF}_{2} \mathrm{SO}_{3}\right)_{2} \mathrm{Na}_{2}$ (IV), $\left[\mathrm{CF}_{2}\left(\mathrm{OCF}_{2} \mathrm{CF}_{2} \mathrm{SO}_{3}\right)_{2}\right] \mathrm{Ca}$ (V) and $\mathrm{CF}_{2}\left(\mathrm{OCF}_{2} \mathrm{CF}_{2} \mathrm{SO}_{3} \mathrm{H}\right)_{2}(\mathrm{VI})$. . . . . . . . . .

${ }^{13} \mathrm{C}$ NMR Data for Compounds

$\mathrm{CH}_{2}\left(\mathrm{OCF}_{2} \mathrm{CF}_{2} \mathrm{SO}_{2} \mathrm{~F}\right)_{2}$ (I), $\mathrm{CHF}\left(\mathrm{OCF}_{2} \mathrm{CF}_{2} \mathrm{SO}_{2} \mathrm{~F}\right)_{2}$ (II), $\mathrm{CF}_{2}\left(\mathrm{OCF}_{2} \mathrm{CF}_{2} \mathrm{SO}_{2} \mathrm{~F}\right)_{2}$ (III), $\mathrm{CH}_{2}\left(\mathrm{OCF}_{2} \mathrm{CF}_{2} \mathrm{SO}_{3}\right)_{2} \mathrm{Na}_{2}$ (IV) and $\mathrm{CF}_{2}\left(\mathrm{OCF}_{2} \mathrm{CF}_{2} \mathrm{SO}_{3} \mathrm{H}\right)_{2}$ (VI) . . . . . . . . . . 40

III ${ }^{1} \mathrm{H}$ and ${ }^{19} \mathrm{~F}$ NMR Data for $\left(\mathrm{CF}_{3}\right)_{2} \mathrm{CFOCH}_{2} \mathrm{CH}_{2} \mathrm{OCF}_{2} \mathrm{CF}_{2} \mathrm{SO}_{2} \mathrm{~F}$ (VII) - . . . . . . 44

IV ${ }^{1} \mathrm{H}$ and ${ }^{19} \mathrm{~F}$ NMR Data for $\mathrm{SF}_{5} \mathrm{CHFSO}_{3} \mathrm{Li}$ (IX) and $\mathrm{SF}_{5} \mathrm{CF}_{2} \mathrm{SO}_{3} \mathrm{Li}$ (X) . . . . . . . 51

$V \quad{ }^{13 C}$ NMR Data for $\mathrm{SF}_{5} \mathrm{CHFSO}_{3} \mathrm{Li}$ (IX) and $\mathrm{SF}_{5} \mathrm{CF}_{2} \mathrm{SO}_{3} \mathrm{Li}(\mathrm{X})$

VI ${ }^{1} \mathrm{H}$ and ${ }^{19} \mathrm{~F}$ NMR Data for $\mathrm{CH}_{3} \mathrm{OCF}_{2} \mathrm{CF}_{2} \mathrm{SO}_{2} \mathrm{~F}$ (IIX) . . . . . . . . . . . . . . 60

VII ${ }^{13} \mathrm{C}$ NMR Data for $\mathrm{CH}_{3} \mathrm{OCF}_{2} \mathrm{CF}_{2} \mathrm{SO}_{2} \mathrm{~F}$ (IIX) . . . . . 60

IIX ' $\mathrm{H}$ NMR Data for Compounds $\mathrm{R}^{\prime} \mathrm{CH}_{2} \mathrm{CH}\left(\mathrm{R}^{2}\right) \mathrm{CH}_{2} \mathrm{OCF}_{2} \mathrm{CF}_{2} \mathrm{SO}_{2} \mathrm{~F}$ : $\mathrm{ClCH}_{2} \mathrm{CH}(\mathrm{OH}) \mathrm{CH}_{2} \mathrm{OCF}_{2} \mathrm{CF}_{2} \mathrm{SO}_{2} \mathrm{~F}$ (XII); $\mathrm{HOCH}_{2} \mathrm{CH}\left(\mathrm{OCH}_{2} \mathrm{C}_{6} \mathrm{H}_{5}\right) \mathrm{CH}_{2} \mathrm{OCF}_{2} \mathrm{CF}_{2} \mathrm{SO}_{2} \mathrm{~F}$ (XIII); $\mathrm{C}_{6} \mathrm{H}_{5} \mathrm{CH}_{2} \mathrm{OCH} 2 \mathrm{CH}(\mathrm{OH}) \mathrm{CH} 2 \mathrm{OCF} 2 \mathrm{CF} 2 \mathrm{SO} 2 \mathrm{~F}$ (XIV); and $\mathrm{HOCH}_{2} \mathrm{CH}(\mathrm{OH}) \mathrm{CH}_{2} \mathrm{OCF}_{2} \mathrm{CF}_{2} \mathrm{SO}_{2} \mathrm{~F}$ (XV) . . . . . .

IX ${ }^{19} \mathrm{~F}$ NMR Data for Compounds $\mathrm{R}^{1} \mathrm{CH}_{2} \mathrm{CH}\left(\mathrm{R}^{2}\right) \mathrm{CH}_{2} \mathrm{OCF}_{2} \mathrm{CF}_{2} \mathrm{SO}_{2} \mathrm{~F}$ : $\left.\mathrm{ClCH} \mathrm{CH}_{2} \mathrm{OH}\right) \mathrm{CH}_{2} \mathrm{OCF}_{2} \mathrm{CF}_{2} \mathrm{SO}_{2} \mathrm{~F}$ (XII); $\mathrm{HOCH}_{2} \mathrm{CH}\left(\mathrm{OCH}_{2} \mathrm{C}_{6} \mathrm{H}_{5}\right) \mathrm{CH}_{2} \mathrm{OCF}_{2} \mathrm{CF}_{2} \mathrm{SO}_{2} \mathrm{~F}$ (XIII); $\mathrm{C}_{6} \mathrm{H}_{5} \mathrm{CH}_{2} \mathrm{OCH} 2 \mathrm{CH}(\mathrm{OH}) \mathrm{CH} 2 \mathrm{OCF} 2 \mathrm{CF} 2 \mathrm{SO} 2 \mathrm{~F}$ (XIV); and $\mathrm{HOCH}_{2} \mathrm{CH}(\mathrm{OH}) \mathrm{CH}_{2} \mathrm{OCF}_{2} \mathrm{CF}_{2} \mathrm{SO}_{2} \mathrm{~F}$ (XV)

$\mathrm{X}{ }^{13} \mathrm{C}$-NMR Data for Compounds $\mathrm{R}^{1} \mathrm{CH}_{2} \mathrm{CH}\left(\mathrm{R}^{2}\right) \mathrm{CH}_{2} \mathrm{OCF}_{2} \mathrm{CF}_{2} \mathrm{SO}_{2} \mathrm{~F}$ : $\mathrm{ClCH} \mathrm{CH}_{2} \mathrm{CH}$ ( $\mathrm{CH}_{2} \mathrm{OCF}_{2} \mathrm{CF}_{2} \mathrm{SO}_{2} \mathrm{~F}$ (XII); $\mathrm{HOCH}_{2} \mathrm{CH}\left(\mathrm{OCH}_{2} \mathrm{C}_{6} \mathrm{H}_{5}\right) \mathrm{CH}_{2} \mathrm{OCF}_{2} \mathrm{CF}_{2} \mathrm{SO}_{2} \mathrm{~F}$ (XIII); $\mathrm{C}_{6} \mathrm{H}_{5} \mathrm{CH}_{2} \mathrm{OCH}_{2} \mathrm{CH}(\mathrm{OH}) \mathrm{CH}_{2} \mathrm{OCF}_{2} \mathrm{CF}_{2} \mathrm{SO}_{2} \mathrm{~F}$ (XIV); and $\mathrm{HOCH}_{2} \mathrm{CH}(\mathrm{OH}) \mathrm{CH}_{2} \mathrm{OCF}_{2} \mathrm{CF}_{2} \mathrm{SO}_{2} \mathrm{~F}$ (XV) . . . . . . 
$\mathrm{XI} \quad{ }^{1} \mathrm{H}$ and ${ }^{19} \mathrm{~F}$ NMR Data for

$\mathrm{CH}_{2}=\mathrm{CHC}(\mathrm{O}) \mathrm{OCH}_{2} \mathrm{CH}_{2} \mathrm{CF}_{2} \mathrm{CF}_{2} \mathrm{OCF}_{2} \mathrm{CF}_{2} \mathrm{SO}_{2} \mathrm{~F}$ (XVI) . . . . 83

XII ${ }^{13} \mathrm{C}$ NMR Data for

$\mathrm{CH}_{2}=\mathrm{CHC}(\mathrm{O}) \mathrm{OCH}_{2} \mathrm{CH}_{2} \mathrm{CF}_{2} \mathrm{CF}_{2} \mathrm{OCF}_{2} \mathrm{CF}_{2} \mathrm{SO}_{2} \mathrm{~F}$ (XVI) . . . . 83

XIII Major Nucleophiles and substrates

Used in Polyester Synthesis . . . . . . . . 89

XIV ${ }^{1} \mathrm{H}$ and ${ }^{19} \mathrm{~F}$ NMR Data for Epoxide Homopolymer

$\left[-\mathrm{OCH}_{2} \mathrm{CH}\left(\mathrm{CH}_{2} \mathrm{OCF}_{2} \mathrm{CF}_{2} \mathrm{SO}_{2} \mathrm{~F}\right)-\right] n$ (XVII)

Polymeric sulfonate Salt

$\left[-\mathrm{OCH}_{2} \mathrm{CH}\left(\mathrm{CH}_{2} \mathrm{OCF}_{2} \mathrm{CF}_{2} \mathrm{SO}_{3} \mathrm{Na}\right)-\right] n$ (XIIX)

and Polymeric Sulfonic Acid

$\left[-\mathrm{OCH}_{2} \mathrm{CH}\left(\mathrm{CH}_{2} \mathrm{OCF}_{2} \mathrm{CF}_{2} \mathrm{SO}_{3} \mathrm{Na}\right)-\right] n(\mathrm{XIX}) \cdot$. $\cdot$. . . .

XV Optical clarity and Contact Angles of Distilled Water for Polymeric Films (XX) Composed of

$\mathrm{OCH}_{2} \mathrm{CHCH}_{2} \mathrm{OCF}_{2} \mathrm{CF}_{2} \mathrm{SO}_{2} \mathrm{~F}$ (XI) and

$\mathrm{CH}_{2} \mathrm{CHCHCH}_{2} \mathrm{CH}_{2} \mathrm{CHOC}(\mathrm{O}) \mathrm{CHCH}_{2} \mathrm{CHCHCH}_{2} \mathrm{CH}_{2}$. . . . . . 98

XVI ${ }^{1} \mathrm{H}$ and ${ }^{19} \mathrm{~F}$ NMR Data for Polyester

$\left[\mathrm{OC}(\mathrm{O}) \mathrm{CF}_{2} \mathrm{CF}_{2} \mathrm{CF}_{2} \mathrm{C}(\mathrm{O}) \mathrm{OCH}_{2} \mathrm{CH}_{2} \mathrm{CH}\left(\mathrm{OCF}_{2} \mathrm{CF}_{2} \mathrm{SO}_{2} \mathrm{~F}\right)\right] n$ (XXI) . 100

XVII ${ }^{1} \mathrm{H}$ and ${ }^{19} \mathrm{~F}$ NMR Data for

$\left[\left(-\mathrm{CH}_{2}-\mathrm{CH}-\right) \mathrm{C}(\mathrm{O}) \mathrm{OCH}_{2} \mathrm{CH}_{2} \mathrm{CF}_{2} \mathrm{CF}_{2} \mathrm{OCF}_{2} \mathrm{CF}_{2} \mathrm{SO}_{2} \mathrm{~F}\right] n$ (XXII). 104 
1 Infrared spectrum of $\mathrm{CHF}\left(\mathrm{OCF}_{2} \mathrm{CF}_{2} \mathrm{SO}_{2} \mathrm{~F}\right)_{2}$ (III)

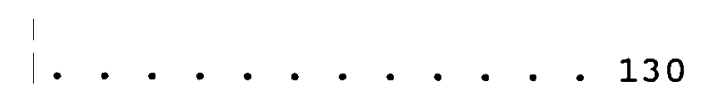

2 Infrared spectrum of $\mathrm{CF}_{2}\left(\mathrm{OCF}_{2} \mathrm{CF}_{2} \mathrm{SO}_{2} \mathrm{~F}\right)_{2}$ (III)

3 Infrared spectrum of $\mathrm{CH}_{2}\left(\mathrm{OCF}_{2} \mathrm{CF}_{2} \mathrm{SO}_{3} \mathrm{Na}\right)_{2}$ (IV)

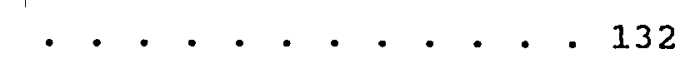

4 Infrared spectrum of $\mathrm{CF}_{2}\left(\mathrm{OCF}_{2} \mathrm{CF}_{2} \mathrm{SO}_{3}\right)_{2} \mathrm{Ca}$ (V)

5 Infrared spectrum of $\mathrm{CF}_{2}\left(\mathrm{OCF}_{2} \mathrm{CF}_{2} \mathrm{SO}_{3} \mathrm{H}\right)_{2}$ (VI)

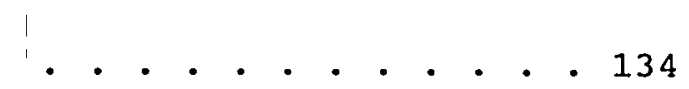

6 Infrared spectrum of $\mathrm{FC}\left(\mathrm{CF}_{3}\right)_{2} \mathrm{OCH}_{2} \mathrm{CH}_{2} \mathrm{OCF}_{2} \mathrm{CF}_{2} \mathrm{SO}_{2} \mathrm{~F}$ (VII)

7 Infrared spectrum of $\mathrm{CH}_{3} \mathrm{OCF}_{2} \mathrm{CF}_{2} \mathrm{SO}_{2} \mathrm{~F}$ (IIX)

8 Infrared spectrum of $\mathrm{SF}_{5} \mathrm{CHFSO}_{3} \mathrm{Li}$ (IX)

9 Infrared spectrum of $\mathrm{SF}_{5} \mathrm{CF}_{2} \mathrm{SO}_{3} \mathrm{Li}(\mathrm{X})$

10 Infrared spectrum of $\mathrm{ClCH}_{2} \mathrm{CH}(\mathrm{OH}) \mathrm{CH}_{2} \mathrm{OCF}_{2} \mathrm{CF}_{2} \mathrm{SO}_{2} \mathrm{~F}$ (XII)

11 Infrared spectrum of product mixture of $\mathrm{HOCH}_{2} \mathrm{CH}\left(\mathrm{OCH}_{2} \mathrm{C}_{6} \mathrm{H}_{5}\right) \mathrm{OCF}_{2} \mathrm{CF}_{2} \mathrm{SO}_{2} \mathrm{~F}$ (XIII) and $\mathrm{C}_{6} \mathrm{H}_{5} \mathrm{CH}_{2} \mathrm{CH}(\mathrm{OH}) \mathrm{CH}_{2} \mathrm{DCF}_{2} \mathrm{CF}_{2} \mathrm{SO}_{2} \mathrm{~F}$ (XIV) . . . . 140

12 Infrared spectrum of $\mathrm{HOCH}_{2} \mathrm{CH}(\mathrm{OH}) \mathrm{CH}_{2} \mathrm{OCF}_{2} \mathrm{CF}_{2} \mathrm{SO}_{2} \mathrm{~F}$ (XV)

13 Infrared spectrum of acrylate ester $\mathrm{H}_{2} \mathrm{C}=\mathrm{CHC}(\mathrm{O}) \mathrm{OCH}_{2} \mathrm{CH}_{2} \mathrm{CF}_{2} \mathrm{CF}_{2} \mathrm{OCF}_{2} \mathrm{CF}_{2} \mathrm{SO}_{2} \mathrm{~F}$ (XVI) . . . 142

14 Infrared spectrum of epoxide homopolymer $\left[-\mathrm{OCH}_{2} \mathrm{CH}\left(\mathrm{CH}_{2} \mathrm{OCF}_{2} \mathrm{CF}_{2} \mathrm{SO}_{2} \mathrm{~F}\right)-\right]$ (XVII) 
15 Infrared spectrum of polymeric sulfonate salt $\left[-\mathrm{OCH}_{2} \mathrm{CH}\left(\mathrm{CH}_{2} \mathrm{OCF}_{2} \mathrm{CF}_{2} \mathrm{SO}_{3} \mathrm{Na}\right)-\right](\mathrm{XIIX})$. . . . . 144

16 Infrared spectrum of polymeric sulfonic acid $\left[-\mathrm{OCH}_{2} \mathrm{CH}\left(\mathrm{CH}_{2} \mathrm{OCF}_{2} \mathrm{CF}_{2} \mathrm{SO}_{3} \mathrm{H}\right)-\right](\mathrm{XIX}) \quad$.

17 Infrared spectrum of polyester $\left[\mathrm{C}(\mathrm{O}) \mathrm{CF}_{2} \mathrm{CF}_{2} \mathrm{CF}_{2} \mathrm{C}(\mathrm{O}) \mathrm{CH}_{2} \mathrm{CH}\left(\mathrm{CH}_{2} \mathrm{OCF}_{2} \mathrm{CF}_{2} \mathrm{SO}_{2} \mathrm{~F}\right) \mathrm{O}\right](\mathrm{XXI})$. 146

18 Infrared spectrum of $\mathrm{HOCH}_{2} \mathrm{CH}(\mathrm{OH}) \mathrm{CH}_{2} \mathrm{OCF}_{2} \mathrm{CF}_{2} \mathrm{SO}_{2} \mathrm{~F}$ and $\mathrm{O}=\mathrm{C}=\mathrm{NCH}_{2} \mathrm{CH}_{2} \mathrm{CH}_{2} \mathrm{CH}_{2} \mathrm{CH}_{2} \mathrm{CH}_{2} \mathrm{~N}=\mathrm{C}=\mathrm{O}$ urethane polymer $(\mathrm{XXII})$. . . . . . . . . 147

19 Infrared spectrum of polyacrylate $\left[\mathrm{H}_{2} \mathrm{C}-\mathrm{CH}\left(\mathrm{C}(\mathrm{O}) \mathrm{OCH}_{2} \mathrm{CH}_{2} \mathrm{CF}_{2} \mathrm{CF}_{2} \mathrm{OCF}_{2} \mathrm{CF}_{2} \mathrm{SO}_{2} \mathrm{~F}\right)\right] n$ (XXIII) . . 148 
CHAPTER I

INT'RODUCTION

FUEL CELLS AND SOLID POLYMER ELECTROLYTE BATTERIES

The production of energy world-wide is largely accounted for by the use of fossil fuel, hydroelectric and nuclear technologies. These methods of energy production not only greatly impact the environment, but are also limited by mechanical energy losses and Carnot efficiencies of the systems.

An alternative source for primary energy production is the fuel cell. Unlike systems/driven by energy that is released in a thermal or mechanical process, fuel cells operate in a manner similar to that of batteries; electrons from oxidation/reduction reactions are transferred through external circuits. The operating efficiency of a fuel cell, therefore, is not limited by mechanical or thermal constraints.

A fuel cell consists of an anode, a cathode and an electrolyte separating the two electrodes. In a hydrogenoxygen fuel cell with an acidic electrolyte, hydrogen is passed over or through a catalytic anode releasing protons and electrons. The protons migrate through the electrolyte to the cathode where they react with oxygen, water and the 
electrons that have passed through an external circuit. Water and heat are produced as the only by-products (1). The compromise choice for the hydrogen-oxygen fuel cell electrolyte has been phosphoric acid. With phosphoric acid several improvements are desirable for better fuel cell performance. These include: conductivity; kinetics of oxygen reduction at the cathode; oxygen solubility, and control of the electrolyte water content.

Early research indicated that these improvements could potentially be achieved by using fluoroalkyl sulfonic acids as the supporting electrolyte (2). Compared to phosphoric acid, these acids are more highly dissociated, giving higher conductivity, and do not appear to adsorb onto the cathode. Furthermore, the high solubility of oxygen in fluorocarbons is recognized to be dependant in part on the structure of the molecules, involving such factors as chain length and branching (3), which also influences volatility. Thus, highly acidic, non-adsorbing electrolytes with greater oxygen solubility and higher operating temperatures are possible with these acids.

Solid polymer electrolyte (SPE) fuel cells using strongly acidic fluorinated polysulfonic acid membranes have been developed (4). The perfluorinated polymer backbone of the ionomers resembles Teflon and possesses a similar chemical inertness. Aside from the favorable chemical properties of these membranes, the use of solid electrolytes 
allows for easier fabrication, transportation and location of these fuel cells since accidental spills and leakage are of no concern. These types of fuel cells are being investigated for the use in electric vehicles (4). Domestically, Du Pont markets such ionomeric membranes under the trade name of Nafion, while Dow Chemical is currently developing a similar product. Two Japanese companies currently produce and market similar ionomer membranes as well $(5,6)$. Post-production modification of Nafion, both on the surface and in the bulk of the material, has been investigated as a way to increase ion transport and hydration characteristics of the polymer for use in fuel cells (7).

The use of batteries and storage cells as secondary energy sources is of environmental and technological concern as well. Currently, the most widely used batteries and storage cells are limited in the number of efficient chargedischarge series through which they can be cycled and rely on the use of toxic or corrosive components. Solid polymer electrolytes have also found use in newly developed high energy density lithium batteries. This type of battery is based on two reversible|lithium electrodes and a thin film lithium conducting polymer serving both as electrolyte and electrode separating material. During discharge, one electrode acts as a lithium cation source and the other as a sink with a thin film polymer as the lithium ion carrier. 
During recharging the electrodes act in reverse. In practice lithium foil or alloys of lithium doped materials are used as the ion source while compounds capable of forming lithium ion-insertion composites are used as the ion sink. The lithium ion carrier, or solid polymer electrolyte, is formed by dissolving a lithium salt in an aprotic polymer (8).

The advantages offered by these batteries include:

the solid state nature leads to easy packaging and no chance of leakage; (ii) a large surface area-to-thickness ratio allows for low current densities during charge and discharge, favorable for reversible electrochemical reactions and energy efficiency; and (iii) lithium has a low density, making this type of battery very light weight. Performance of typical cells is characterized by flat discharge plateaus giving steady cell voltages of about 2 volts, with full discharge-recharge capability of 600 times at temperatures of -10 to $130^{\circ} \mathrm{C}$ (9).

Currently, most research on the development of these batteries is concentrated on the composition of the polymer electrolyte composition. Poly (ethylene oxide) (PEO) has been found to exhibit excellent lithium cation solvating capability and is the polymer used almost without exception. Lithium perchlorate or lithium trifluoromethane sulfonate dissolved in PEO have been the most widely used electrolytes. The anions do not form Lewis acid-base complexes 
with the oxygen atoms in the polymer chain and are stable under typical recharge potentials of about 4 volts. Conductivity in these systems are in the range of $10^{-5}$ to $10^{-4} \Omega^{-1} \mathrm{~cm}^{-1}$ (9).

FLUOROALKYL SULFONYL FLUORIDES, SULFONATE SALTS AND SULFONIC ACIDS

The utilization of fluorocarbon sulfonyl fluorides and derivatives as ion exchange resins, surface active agents and in the production of strong sulfonic acids makes them the subject of considerable interest (10-13). As a group fluoroalkyl sulfonyl fluorides, sulfonate salts and sulfonic acids are non-corrosive, possess low vapor pressure and excellent thermal, chemical and electrochemical stability. These characteristics, along with good ionic conductivity found in the sulfonate salts and sulfonic acids, make these compounds ideal candidates for use in fuel cells and polymer electrolyte batteries.

\section{General Preparation}

A convenient method for the preparation of fluoroalkyl sulfonyl fluorides involves reactions of $\beta$-fluorosultones. $\beta$-Fluorosultones are cyclic esters of $\beta$-hydroxyfluoraalkyl sulfonic acids formed from the addition of sulfur trioxide to fluoro-olefins: 


$$
\mathrm{CF}_{2}=\mathrm{CXZ}+\mathrm{SO}_{3} \longrightarrow \mathrm{F}_{2} \mathrm{C}-\mathrm{CXZ}^{\mathrm{O}}
$$

where $\mathrm{X}=\mathrm{Z}=\mathrm{F}$ or $\mathrm{X}=\mathrm{F}, \mathrm{Z}=$ a variety of fluoroalkyl groups.

In the presence of catalytic amounts of various

nucleophiles (metal fluorides, amines, alcohols, water), the sultones undergo rearrangement to the isomeric fluorosulfonyl fluoroalkyl carbonyl fluorides:

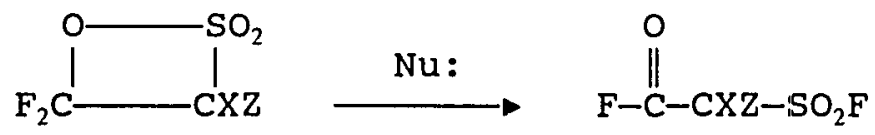

which with stoichiometric amounts of metal fluorides in aprotic solvents results in the formation of fluorosulfonyl metal alkoxides:

$$
\begin{aligned}
& \stackrel{\mathrm{O}}{\|} \mathrm{C}-\mathrm{CXZ}-\mathrm{SO}_{2} \mathrm{~F}+\mathrm{MF} \longrightarrow \mathrm{MO}^{-} \mathrm{CF}_{2}-\mathrm{CXZ}-\mathrm{SO}_{2} \mathrm{~F} \\
& \mathrm{M}=\mathrm{Na}, \mathrm{K}, \mathrm{Ca}, \mathrm{Ag}
\end{aligned}
$$

The alkoxides can be used as intermediates for further reactions. Two important examples shown below are nucleophilic substitution using alkyl and fluoroalkyl halides:

$$
\mathrm{RX}+\mathrm{MO}-\mathrm{CF}_{2}-\mathrm{CXZ}-\mathrm{SO}_{2} \mathrm{~F} \longrightarrow \mathrm{RO}-\mathrm{CF}_{2}-\mathrm{CXZ}-\mathrm{SO}_{2} \mathrm{~F}+\mathrm{MF}
$$

and in the presence of iodine or iodine monochloride for addition to fluoro-olefins as illustrated using tetrafluoroethylene: 
$\mathrm{CF}_{2}=\mathrm{CF}_{2}+\mathrm{MO}-\mathrm{CF}_{2}-\mathrm{CXZ}-\mathrm{SO}_{2} \mathrm{~F}+\mathrm{I}_{2} \longrightarrow \mathrm{ICF}_{2} \mathrm{CF}_{2} \mathrm{OCF}_{2} \mathrm{CF}_{2} \mathrm{SO}_{2} \mathrm{~F}+\mathrm{MI}$

Conversion of fluoroalkyl sulfonyl fluorides to the corresponding sulfonate salts and acids can be readily accomplished using metal hydroxides followed by reactions with strong acids:

$\mathrm{n} \mathrm{R}_{\mathrm{f}} \mathrm{SO}_{2} \mathrm{~F}+2 \mathrm{M}^{\mathrm{n}+}(\mathrm{OH})_{\mathrm{n}} \rightarrow\left(\mathrm{R}_{\mathrm{f}} \mathrm{SO}_{3}^{-}\right)_{\mathrm{n}} \mathrm{M}^{\mathrm{n}+}+\mathrm{M}^{\mathrm{n}+} \mathrm{F}_{\mathrm{n}}+\mathrm{n} \mathrm{H}_{2} \mathrm{O}$

$\mathrm{M}=\mathrm{Na}, \mathrm{Li}, \mathrm{Ca}$

$R_{r}=$ partially fluorinated or perfluorinated groups

and:

$$
\left(\mathrm{R}_{\mathrm{f}} \mathrm{SO}_{3}{ }^{-}\right)_{n} \mathrm{M}^{\mathrm{n}+} \stackrel{\text { excess } \mathrm{HA}}{\longrightarrow} \mathrm{n} \mathrm{R}_{\mathrm{f}} \mathrm{SO}_{3} \mathrm{H}+\mathrm{M}^{\mathrm{n}+} \mathrm{A}
$$

where HA represents a strong mineral acid or a strong cation exchange resin in the acidic form.

These methods along with others for the synthesis of $\beta-$ fluorosultones, fluoroalkyl sulfonyl fluorides, sulfonate salts and sulfonic acids are the subjects of a recent review (14) .

Monomeric Compounds for Possible use as Fuel cell Electrolytes

Previous testing of a variety of fluoroalkyl sulfonic acids prepared in this laboratory for possible use as fuel cell electrolytes showed the disulfonic acid $\mathrm{HOSO}_{2} \mathrm{CF}_{2} \mathrm{CF}_{2} \mathrm{SO}_{2} \mathrm{OH}$ exhibited an excellent combination of solubility, conductivity and oxygen reduction kinetics on platinum 
cathodes (15). Since the fluoraalkyl group contributes to the acidity and high oxygen solubility in these compounds, these properties can be modified by the nature of the group. New monomeric fluoroalkyl sulfonyl fluorides, sulfonate salts and sulfonic acids possessing differing degrees of fluorination and branching in the alkyl chain were prepared as a portion of this work.

\section{Lithium Sulfonates for Possible use in Solid Polymer}

\section{Electrolyte Batteries}

Fluoroalkyl sulfonate salts and their derivatives have been investigated for use as the lithium counter ions in poly(ethylene oxide) electrolyte batteries. Lithium trifluoromethane sulfonate $\left(\mathrm{LiCF}_{3} \mathrm{SO}_{3}\right.$, or lithium triflate) is recognized as being thermally and electrochemically stable, but gives a lower conductivity $\left(10^{-5} \Omega^{-1} \mathrm{~cm}^{-1}\right)$ than lithium perchlorate, $\mathrm{LiClO}_{4}\left(3 \times 10^{-3} \Omega^{-1} \mathrm{~cm}^{-1}\right)(8)$. However, reduced crystallinity of the polymer electrolyte and result-ing higher conductivity measurements were found using $\mathrm{Li}\left[\left(\mathrm{CF}_{3} \mathrm{SO}_{2}\right)_{3} \mathrm{C}\right]$ and $\mathrm{Li}\left[\left(\mathrm{CF}_{3} \mathrm{SO}_{2}\right)_{2} \mathrm{~N}\right]$, giving conductivities of $10^{-3}$ $\Omega^{-1} \mathrm{~cm}^{-1}(16)$.

Two new lithium fluoroalkyl sulfonate salts were prepared and characterized in this work. Conductivity measurements in poly(ethylene oxide) for these salts ranged from $1 \times 10^{-4}$ to $1 \times 10^{-3} \Omega^{-1} \mathrm{~cm}^{-1}$ at temperatures of 60 and $100^{\circ} \mathrm{C}$, comparable to the best results yet obtained (16). 
Polymeric Compounds for Possible use as Electrolytes and coatings

In addition to solid polymer electrolytes in fuel cells, polymeric fluoroalkyl sulfonic acids find use as membranes in chlor-alkali cells, and as catalysts in novel heterogeneous reactions (17). Along with thermal, chemical and biological inertness, fluorinated compounds in general possess low refractive indices making them ideal for use in certain optical applications. The low surface energy of nonpolar fluoroalkyl polymers, however, interferes with cladding ability of other polymers and color-coding inks (18) .

In electrochemical cells, good contact between the polymer electrolyte and the electrodes is an essential feature for optimal performance (7). While a number of commercial fluoroalkyl ionomers exist, their uses as coatings are somewhat limited. Polymerization is performed prior to application resulting in the need for exotic or hazardous solvents in coating applications (7). Furthermore, commercially available polymeric fluoroalkyl sulfonic acid membranes are linear systems. With equivalent weights less than about 800 , the ionomers possess water solubility and so are not usable as membranes in aqueous applications. While cross-linking could alleviate this problem, its presence could also lower solubility in a coating process. 
In addition to the aforesaid sulfonyl fluorides, salts and acids, new fluoroalkyl sulfonyl fluorides possessing polymerizable groups were synthesized in this work. These compounds were polymerized or copolymerized, either in bulk or directly as coatings on glass and metal substrates, to give linear and cross-linked systems. Low refractive indices were obtained for liquid products while measurement of water contact angles on solid film products indicated the presence of polar groups on the surface of some films. 
CHAPTER II

\section{REVIEW OF POLYMERIC FLUOROALKYL SULFONYL FLUORIDES AND DERIVATIVES}

Fluoroalkyl sulfonyl fluorides $\left(\mathrm{R}_{\mathrm{f}} \mathrm{SO}_{2} \mathrm{~F}\right.$; where $\mathrm{R}_{\mathrm{f}}$ is a partially or perfluorinated organic group) have wide spread use and interest (10-13). Tremendous commercial values are realized for polymeric compounds of this type. In this research, fluoroalkyl sulfonyl fluorides were made as precursors to sulfonic acids and/or sulfonate salts for use in electrochemical devices. Also, polymeric compounds were sought for possible use as solid polymer fuel cell electrolytes.

Polymeric sulfonyl fluorides can be prepared by a variety of methods, including introduction of fluoroalkyl sulfonyl fluoride groups into pre-existing polymers. However, most methods involve the initial reaction of a fluoroalkene with sulfur trioxide to yield a cyclic sultone intermediate, which upon addition of a metal fluoride results in rearrangement to give a fluorosulfonyl acyl fluoride as shown in equations [1] and [2] in chapter I. At this point two general paths are followed: Reactions of the acyl fluoride itself; or formation of a metal alkoxide for use in subsequent addition or substitution reactions 
shown in equation [3] in Chapter I.

Following is a review of the synthesis and, in some cases, properties of polymeric fluorpalkyl sulfonyl

fluorides and derivatives. Due to the commercial interests in these types of compounds much of the information is proprietary.

\section{COMMERCIALLY AVAILABLE FLUORQALKYL SULFONATE IONOMERS, DERIVATIVES AND PRECURSORS}

Three companies currently market solid perfluoroalkyl sulfonate ionomers or derivatives under different trade names: Du Pont Company, Nafion; Tokuyama Soda Company, Neosepta-F; Asahi Chemical Company, Membrane $\mathrm{C}$; and Dow Chemical is currently developing a similar product $(5,6,19-$ 21). All of these products are non-crystalline solid copolymers based on tetrafluoroethylene and perfluorovinyl ether sulfonyl fluorides.

DuPont's Nafion, developed in the late 1960's, was the first of these products to be produced (20). The fluorosulfonyl alkoxide from tetrafluoroethylene and sulfur trioxide with a metal fluoride (equations [1]-[3] in chapter I) is successively reacted with hexafluoropropylene oxide to give sulfonyl fluoride adducts:

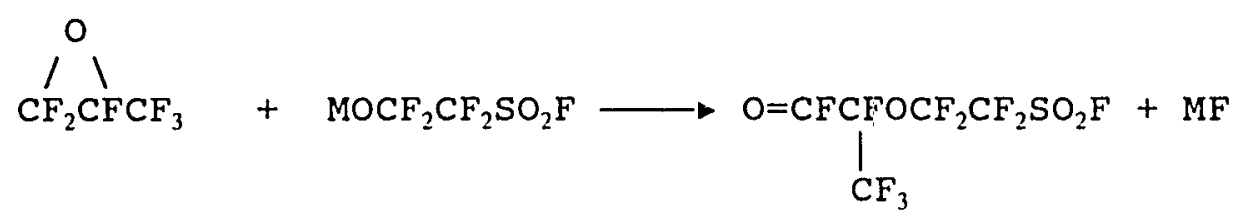


$\underset{\mathrm{CF}_{2} \mathrm{CFCF}_{3}}{\mathrm{O}}+\underset{\mathrm{O}=\mathrm{CFCFOCF}}{\mathrm{CF}_{3}} \mathrm{CF}_{2} \mathrm{SO}_{2} \mathrm{~F} \longrightarrow$

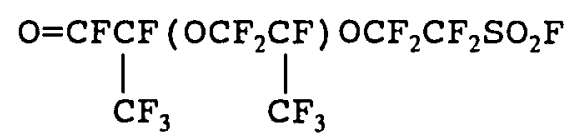

repeat $x-1$ times

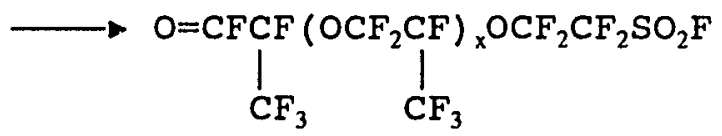

The final' adduct, where $x$ is about 7 , is heated with sodium carbonate to form a vinyl ether. This is next copolymerized with tetrafluoroethylene under free-radical conditions:

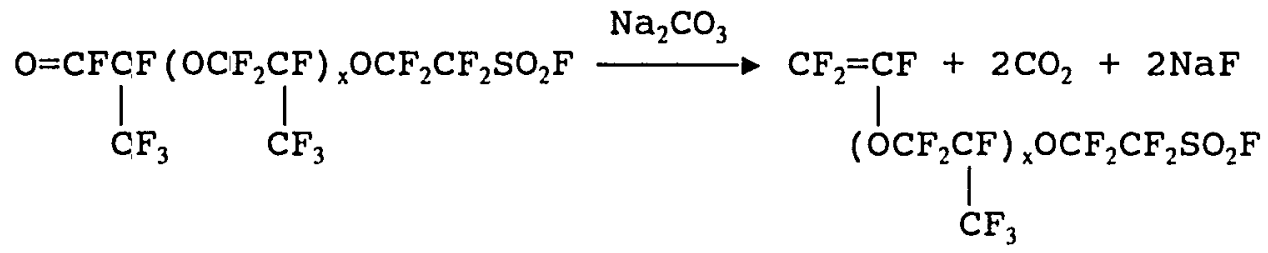

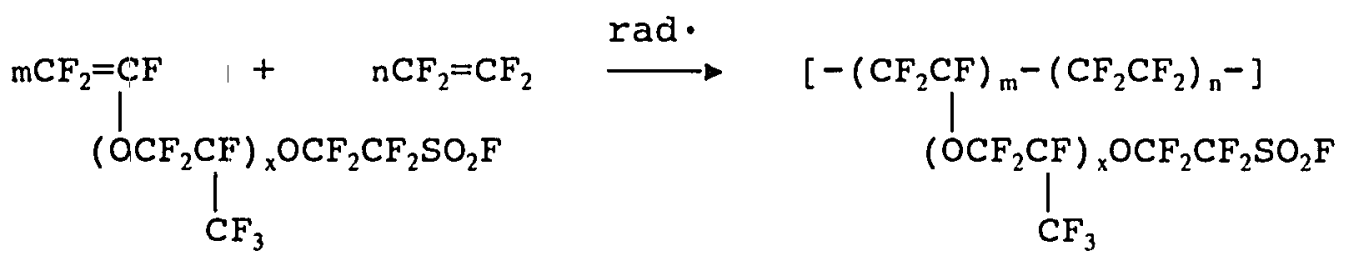

The polymeric sulfonyl fluoride is hydrolyzed under basic conditions to give the potassium salt ionomer, which is then converted to the acidic form by treatment with strong acid. Nafion membranes with 1100 and 1500 equivalent weights, controlled by the ratio of $\mathrm{n} / \mathrm{m}$, are sold in the acidic form both as free-standing films and as composites 
heat fused to Teflon mesh. Strong cation exchange resin beads are offered in the potassium salt form with 1100 equivalent weight. The resins can be readily converted to the sulfonic acid form for use as solid super acid catalysts. Nafion ionomers with equivalent weight less than 800 possess hydrophilicity great enough to render the salt and acid forms water soluble, thus limiting their use in solid polymer applications (22).

In the 1970's it was realized that fluoroalkyl sulfonate ionomers used in chlor-alkali cells showed excessive hydroxide ion back transfer. Tokuyama soda Company developed Neosepta-F, made from Dupont Nafion. Initially, the reaction of Nafion with phosphorus pentachloride results in conversion of the sulfonic acid groups to sulfonyl chlorides. Formation of $/$ methyl esters followed by controlled oxidation at elevated temperatures results in a polymer chain structurally identical to Nafion but possessing surface carboxylate groups. The structure of the polymer is well characterized:

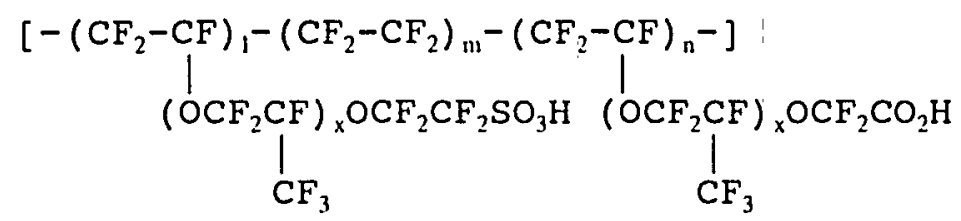

where $14<1 / \mathrm{n}<21$.

Dow Chemical is developing a fluoropolymer similar to Nafion but possessing a shorter side/chain, resulting in a 
lower equivalent weight ionomer. Again, the process begins with formation of the metal alkoxide from tetrafluoroethylene sultone, equations [1-3]. The reaction with 3chloro-1, 1,2,3,3-pentafluoropropylene oxide followed by heating with sodium carbonate results in a vinyl ether that is copolymerized with tetrafluoroethylene:

$\stackrel{\mathrm{O}}{\mathrm{CF}_{2} \mathrm{CFCF}_{2} \mathrm{Cl}}+\mathrm{MOCF}_{2} \mathrm{CF}_{2} \mathrm{SO}_{2} \mathrm{~F} \longrightarrow \mathrm{O}=\mathrm{CFCFOCF}_{2} \mathrm{CF}_{2} \mathrm{SO}_{2} \mathrm{~F}+\mathrm{MF}$

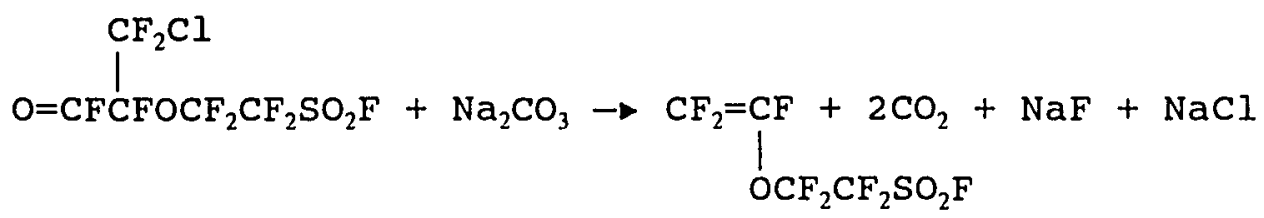

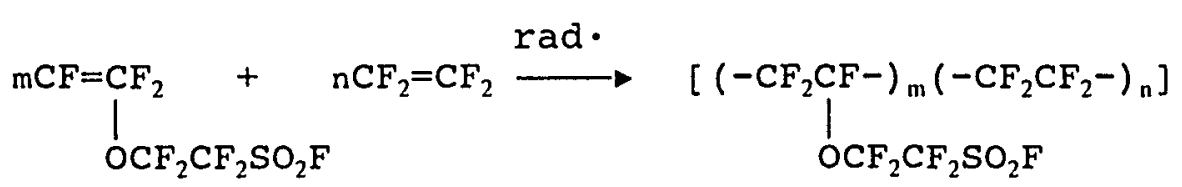

The resulting sulfonyl fluoride is hydrolyzed and offered as the potassium salt with an equivalent weight range of $800-$ $1000 \mathrm{~g} / \mathrm{eq}$.

Asahi Chemical of Japan offers a similar product, but with shorter side chains and resulting a lower equivalent weight. The process used in this synthesis varies from that of the others in that a sultone is not used. Instead, sulfuryl chloride fluoride is used to give an addition product with tetrafluoroethylene. Further reaction with more tetrafluoroethylene gives 4 -chloro-1, 1,2,2,3,3,4,4octafluoro-1-butane sulfonyl fluoride: 


$$
\begin{gathered}
\mathrm{CF}_{2}=\mathrm{CF}_{2}+\mathrm{SO}_{2} \mathrm{ClF} \longrightarrow \mathrm{ClCF}_{2} \mathrm{CF}_{2} \mathrm{SO}_{2} \mathrm{~F} \\
\mathrm{CF}_{2}=\mathrm{CF}_{2}+\mathrm{ClCF}_{2} \mathrm{CF}_{2} \mathrm{SO}_{2} \mathrm{~F} \longrightarrow \mathrm{ClCF}_{2} \mathrm{CF}_{2} \mathrm{CF}_{2} \mathrm{CF}_{2} \mathrm{SO}_{2} \mathrm{~F}
\end{gathered}
$$

oxidation at elevated temperatures in the presence of chlorine results in an acyl fluoride that is successively reacted with hexafluoropropylene oxide:

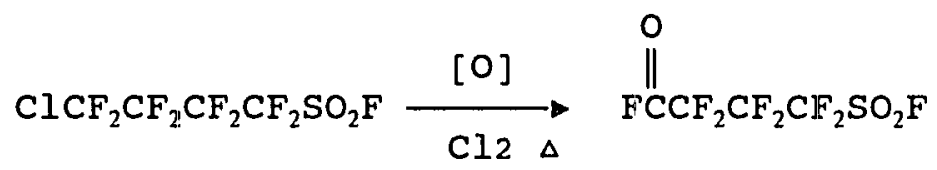

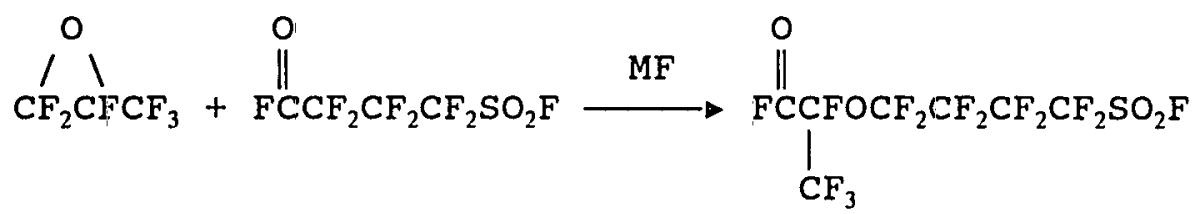

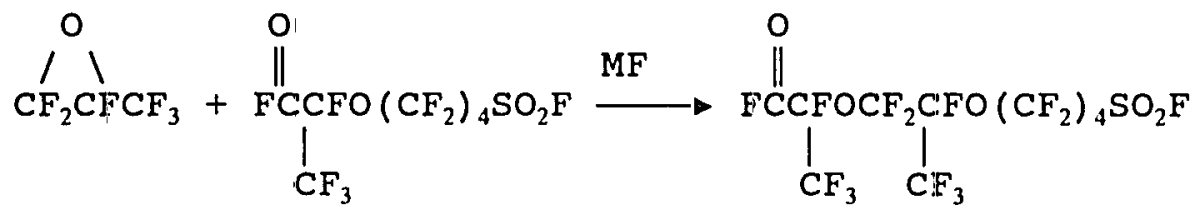

The resulting long-chain acyl fluorides are then used to form fluorinated alkenes, in a reaction similar to that used in the preparation of Nafion, and copolymerized with tetrafluoroethylene:

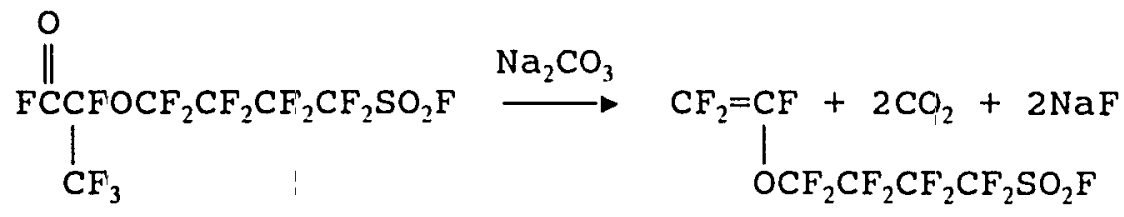



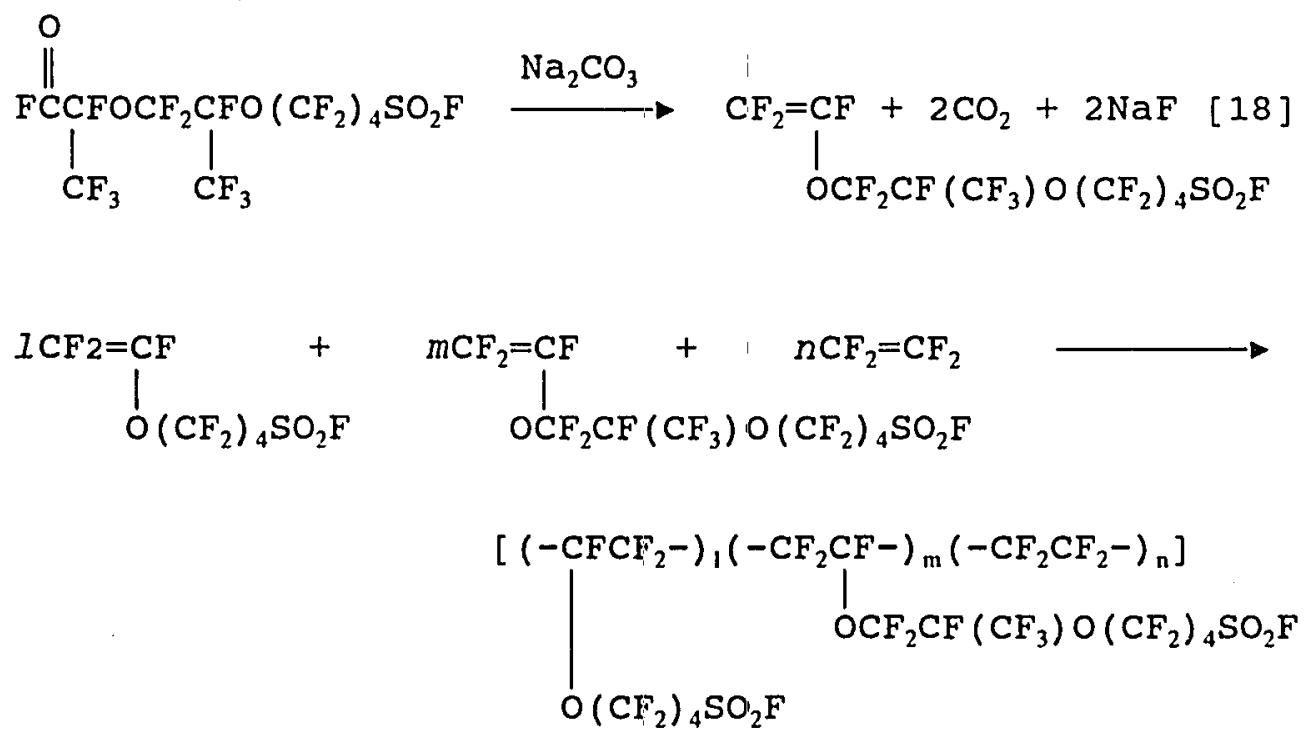

Then, in a process similar to that used in the oxidation of NEOSEPTA-F, the surface is oxidized to give carboxylate groups.

OTHER FLUORO-OLEFIN AND VINYL ETHER POLYMERS AND COPOLYMERS

Much of the developmental work performed by the companies that offer commercial polymers of these types lead to other polymeric fluoroalkyl sulfonyl fluorides and derivatives. Most of these polymers are based on copolymerization of a vinyl ether compound and fluorinated olefins, usually tetrafluoroethylene. As with the commercial products, the majority of the information is proprietary. since comonomer ratios and precise polymer compositions are not available for these compounds, no attempts will be made to show the exact polymer structures. Instead, the monomer structures, approximate polymer structures and chemical 
properties of the polymers, where available, will be presented.

Early research at DuPont led to a polymer designed for use as chlor-alkali membranes (23). Perfluoro(2-fluorosulfonyl-3,6-dioxa-7-octene) was prepared from perfluoro (ethylene glycol)divinyl ether and sulfuryl fluoride:

$\mathrm{CF}_{2}=\mathrm{CFOCF}_{2} \mathrm{CF}_{2} \mathrm{OCF}=\mathrm{CF}_{2}+\mathrm{SO}_{2} \mathrm{~F}_{2} \longrightarrow \mathrm{SF}_{2}=\mathrm{CFOCF}_{2} \mathrm{CF}_{2} \mathrm{OCF}-\mathrm{CF}_{3}$

Subsequent radical polymerization by unspecified means with tetrafluoroethylene:

$\operatorname{mCF}_{2}=\mathrm{CFOCF}_{2} \mathrm{CF}_{2} \mathrm{OCFCF}_{3}+n \mathrm{SO}_{2}=\mathrm{CF}_{2} \rightarrow\left(-\mathrm{CF}_{2}-\mathrm{CF}_{\mathrm{n}}-\left(\mathrm{CF}_{2}-\mathrm{CF}_{2}-\right)_{\mathrm{m}}\right.$

resulted in a comonomer which was thermally stable to $375^{\circ} \mathrm{C}$. The polymer was then hydrolyzed in aqueous sodium hydroxide to give the sodium sulfonate salt. A similar product was obtained by free-radical copolymerization in solution of the fluoroalkene obtained from the following reaction:

$$
\begin{aligned}
\mathrm{CF}_{2}=\mathrm{CFCF}_{2} \mathrm{OSO}_{2} \mathrm{~F}+\mathrm{KOCF}_{2} \mathrm{CF}_{2} \mathrm{SO}_{2} \mathrm{~F} \longrightarrow \mathrm{CF}_{2}=\mathrm{CFCF}_{2} \mathrm{OCF}_{2} \mathrm{CF}_{2} \mathrm{SO}_{2} \mathrm{~F} \\
+\mathrm{KOSO}_{2} \mathrm{~F} \\
m \mathrm{MF}_{2}=\mathrm{CFCF}_{2} \mathrm{OCF}_{2} \mathrm{CF}_{2} \mathrm{SO}_{2} \mathrm{~F}+n \mathrm{CF}_{2}=\mathrm{CF}_{2} \rightarrow\left[-\left(\mathrm{CF}_{2}-\mathrm{CF}_{\mathrm{m}}-\left(\mathrm{CF}_{2}-\mathrm{CF}_{2}-\right)_{\mathrm{n}}\right]\right. \\
\left.\right|_{\mathrm{CF}_{2} \mathrm{OCF}_{2} \mathrm{CF}_{2} \mathrm{SO}_{2} \mathrm{~F}}
\end{aligned}
$$


The product contained $3.5 \mathrm{~mol} \% \mathrm{CF}_{2}=\mathrm{CFCF}_{2} \mathrm{OCF}_{2} \mathrm{CF}_{2} \mathrm{SO}_{2} \mathrm{~F}$ giving an equivalent weight of 9400 (24). The same comonomers were polymerized in bulk to give a polymer that was hydrolyzed with aqueous potassium hydroxide to give the potassium sulfonate salt. In addition, the following sulfonyl fluorides were copolymerized in bulk, solutions or emulsions under free-radical conditions with some or all of the listed olefins $(25,26)$ :

SULFONYL FLUORIDES

$\mathrm{CF}_{2}=\mathrm{CFCF}_{2} \mathrm{OCF}_{2} \mathrm{CF}_{2} \mathrm{SO}_{2} \mathrm{~F}$

$\mathrm{CF}_{2}=\mathrm{CFCF}_{2} \mathrm{OCF}_{2} \mathrm{CF}_{2} \mathrm{CF}_{2} \mathrm{SO}_{2} \mathrm{~F}$

$\mathrm{CF}_{2}=\mathrm{CFCF}_{2} \mathrm{OCF}_{2} \mathrm{CF}\left(\mathrm{CF}_{3}\right) \mathrm{SO}_{2} \mathrm{~F}$

$\mathrm{CF}_{2}=\mathrm{CFCF}_{2} \mathrm{OCF}\left(\mathrm{CF}_{3}\right) \mathrm{CF}_{2} \mathrm{SO}_{2} \mathrm{~F}$

$\mathrm{CF}_{2} \mathrm{CF}=\mathrm{CFCFOCF} \mathrm{CF}_{2} \mathrm{SO}_{2} \mathrm{~F}$
OLEFINS

$\mathrm{CF}_{2}=\mathrm{CFCF}_{2} \mathrm{O}\left(\mathrm{CF}_{2}\right)_{6} \mathrm{OCF}_{2} \mathrm{CF}=\mathrm{CF}_{2}$

$\mathrm{CF}_{2}=\mathrm{CFCF}_{2} \mathrm{O}\left(\mathrm{CF}_{2}\right)_{3} \mathrm{OCF}_{2} \mathrm{CF}=\mathrm{CF}_{2}$

$\mathrm{CF}_{2}=\mathrm{CFCF}_{2} \mathrm{OCF}_{2} \mathrm{CF}_{2} \mathrm{CF}_{2} \mathrm{CF}_{3}$

$\mathrm{CF}_{2}=\mathrm{CFCF}_{2} \mathrm{OCF}\left(\mathrm{CF}_{3}\right) \mathrm{CF}_{2} \mathrm{Cl}$

$\mathrm{CF}_{2}=\mathrm{CF}_{2}$

In developing the short side-chain product available from Dow, copolymerization of tetrafluoroethylene and $1,1,2,2$-tetrafluoro-1-fluorosulfony 1-3-oxa-4-pentene resulted in a sulfonyl fluoride polymer with an equivalent weight of around 720 (27):

$m \mathrm{CF}_{2}=\mathrm{CF}_{2}+\mathrm{nCH}_{2}=\mathrm{CHOCF}_{2} \mathrm{CF}_{2} \mathrm{SO}_{2} \mathrm{~F} \longrightarrow\left(-\mathrm{CF}_{2}-\mathrm{CF}_{2}-\right)_{\mathrm{n}}-\left(\mathrm{CH}_{2}-\mathrm{CH}-\right)_{\mathrm{n}}$

Subsequent hydrolysis under basic conditions followed by boiling in concentrated hydrochloric acid gave the sulfonic 
acid polymer. Other vinyl ethers copolymerized with tetrafluoroethylene include: $\mathrm{CH}_{2}=\mathrm{CHOCF}(\mathrm{R}) \mathrm{CF}_{2} \mathrm{SO}_{2} \mathrm{~F}$, where $\mathrm{R}$ represents chlorine, or perfluoro normal alkanes ranging from $C_{3}$ to $C_{10} F_{21}$. Sulfonate salts and sulfonic acid esters where also prepared from some of the polymers.

Asahi Glass of Japan, which currently does not offer a commercial product, performed developmental work on a another polymer possessing a short side-chain:

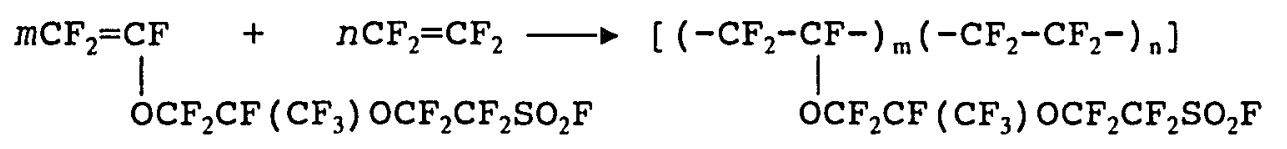

Polymerization as emulsions resulted in polymeric materials with equivalent weights ranging from 925 to 833 depending upon the emulsifying agent used $(28-31)$.

Caproriccio et al. prepared telomers based on the addition of $1,1,2,2,4,4,5,5$-octafluoro-5-iodo-3-oxa-pentane sulfonyl fluoride to tetrafluoroethylene and hexafluoropropene:

$$
\text { equations }[1-3] \longrightarrow \mathrm{KOCF}_{2} \mathrm{CF}_{2} \mathrm{SO}_{2} \mathrm{~F}
$$

$\mathrm{KOCF}_{2} \mathrm{CF}_{2} \mathrm{SO}_{2} \mathrm{~F}+\mathrm{CF}_{2}=\mathrm{CF}_{2}+\mathrm{I}_{2} \longrightarrow \mathrm{ICF}_{2} \mathrm{CF}_{2} \mathrm{OCF}_{2} \mathrm{CF}_{2} \mathrm{SO}_{2} \mathrm{~F}+\mathrm{KI}$

$\mathrm{ICF}_{2} \mathrm{CF}_{2} \mathrm{OCF}_{2} \mathrm{CF}_{2} \mathrm{SO}_{2} \mathrm{~F}+x \mathrm{XF}_{2}=\mathrm{CF}_{2} \rightarrow \mathrm{I}\left(\mathrm{CF}_{2} \mathrm{CF}_{2}\right)_{x} \mathrm{CF}_{2} \mathrm{CF}_{2} \mathrm{OCF}_{2} \mathrm{CF}_{2} \mathrm{SO}_{2} \mathrm{~F}$

and

$\left.\mathrm{ICF}_{2} \mathrm{CF}_{2} \mathrm{OCF}_{2} \mathrm{CF}_{2} \mathrm{SO}_{2} \mathrm{~F}+\left.x\right|_{\mathrm{CF}_{3}} \mathrm{CF}_{\mathrm{CF}_{3}} \rightarrow \mathrm{CF} \mathrm{CF}_{2} \rightarrow \mathrm{CF}_{2}\right)_{x} \mathrm{CF}_{2} \mathrm{CF}_{2} \mathrm{OCF}_{2} \mathrm{CF}_{2} \mathrm{SO}_{2} \mathrm{~F}$ 
Reacting the telemers with ethylmagnesium bromide resulted in terminal fluoroalkenes which were copolymerized with tetrafluoroethylene (32):

$\mathrm{I}\left(\mathrm{CF}_{2} \mathrm{CF}_{2}\right)_{x} \mathrm{CF}_{2} \mathrm{CF}_{2} \mathrm{OCF}_{2} \mathrm{CF}_{2} \mathrm{SO}_{2} \mathrm{~F}+\mathrm{CH}_{3} \mathrm{CH}_{2} \mathrm{MgBr}$

$$
\mathrm{CF}_{2}=\mathrm{CF}\left(\mathrm{CF}_{2} \mathrm{CF}_{2}\right)_{x-1} \mathrm{CF}_{2} \mathrm{CF}_{2} \mathrm{OCF}_{2} \mathrm{CF}_{2} \mathrm{SO}_{2} \mathrm{~F}+\mathrm{CH}_{3} \mathrm{CH}_{2} \mathrm{I}+\mathrm{MgBrF}
$$

and

$\stackrel{I\left(\mathrm{CFCF}_{2}\right)_{\mathrm{x}} \mathrm{CF}_{2} \mathrm{CF}_{2} \mathrm{OCF}_{2} \mathrm{CF}_{2} \mathrm{SO}_{2} \mathrm{~F}+\mathrm{CH}_{3} \mathrm{CH}_{2} \mathrm{MgBr}}{\quad \mathrm{CF}_{3}}$ $\mathrm{CF}_{2}=\mathrm{CFCF}_{2}\left(\mathrm{CFCF}_{3}\right)_{x-1} \mathrm{CF}_{2} \mathrm{CF}_{2} \mathrm{OCF}_{2} \mathrm{CF}_{2} \mathrm{SO}_{2} \mathrm{~F}$
(II)

$$
\begin{aligned}
m(I)+n C F_{2}=C F_{2} \longrightarrow \quad & {\left[-\left(C F_{2}-C F\right)_{n-1}-\left(C F_{2}-C F_{2}\right)_{n}-\right] } \\
& \left(C F_{2} C F_{2}\right)_{x-1} C F_{2} C F_{2} \mathrm{OCF}_{2} C F_{2} \mathrm{SO}_{2} F
\end{aligned}
$$

and

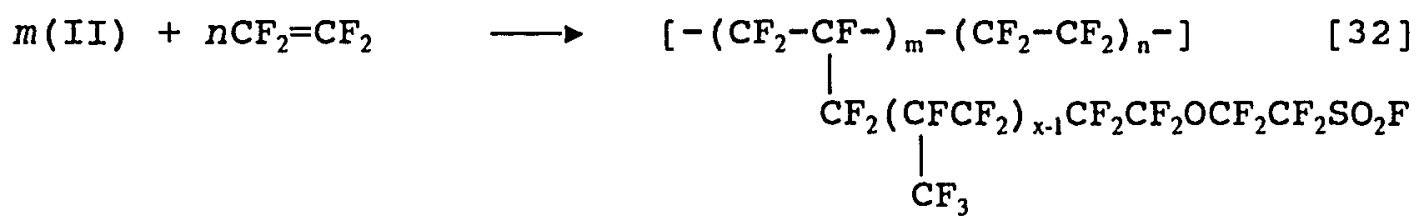

Work performed by the Imperial Chemical Industries group involved copolymerization of tetrafluoroethylene with two similar perfluorinated vinyl ethers;

$$
\begin{aligned}
& m \mathrm{CF}_{2}=\mathrm{CF}_{2}+n C F_{2}=\mathrm{CF}-\left[\mathrm{OCF_{2 }} \mathrm{CF}\left(\mathrm{CF}_{3}\right)\right]_{\mathrm{x}}-\mathrm{OCF}_{2} \mathrm{CF}_{2} \mathrm{CF}_{2} \mathrm{CFCF}_{2} \mathrm{CF}_{3} \longrightarrow \\
& \mathrm{SO}_{2} \mathrm{~F} \\
& {\left[-\left(\mathrm{CF}_{2}-\mathrm{CF}_{2}-\right)_{m}-\left(\mathrm{CF}_{2}-\mathrm{CF}\right)_{n}-\right]} \\
& {\left[\mathrm{OCF}_{2} \mathrm{CF}\left(\mathrm{CF}_{3}\right)\right]_{\mathrm{x}}-\mathrm{OCF}_{2} \mathrm{CF}_{2} \mathrm{CF}_{2} \mathrm{CFCF}_{2} \mathrm{CF}_{3}} \\
& \mathrm{SO}_{2} \mathrm{~F}
\end{aligned}
$$


where $\mathrm{x}=0$ or 1 . The polymers were hydrolyzed with sodium hydroxide solutions resulting in sodium sulfonate salt polymers with equivalent weights of 1100 (33).

Academic research at Burgas Technological University of Bulgaria involved initial reactions of perfluoroalkenes with sulfur trioxide:

$$
\begin{gathered}
\mathrm{CF}_{2}=\mathrm{CF}_{2}+\mathrm{SO}_{3} \longrightarrow \mathrm{FCCF}_{2} \mathrm{SO}_{2} \mathrm{~F} \\
\mathrm{CF}_{3} \mathrm{CF}=\mathrm{CF}_{2}+\mathrm{SO}_{3} \longrightarrow \mathrm{CF}_{2}=\mathrm{CFCF}_{2} \mathrm{OSO}_{2} \mathrm{~F}
\end{gathered}
$$

Further reaction of the two products in the presence of an unspecified metal fluoride resulted in a perfluorinated vinyl ether which was copolymerized in bulk under freeradical conditions:

$$
\begin{aligned}
\mathrm{CF}_{2}=\mathrm{CFCF}_{2} \mathrm{OSO}_{2} \mathrm{~F}+\mathrm{FCCF}_{2} \mathrm{SO}_{2} \mathrm{~F} \longrightarrow \mathrm{CF}_{2}=\mathrm{CFCF}_{2} \mathrm{OCF}_{2} \mathrm{CF}_{2} \mathrm{SO}_{2} \mathrm{~F}+\mathrm{MSO}_{3} \mathrm{~F} \\
\mathrm{mCF}_{2}=\mathrm{CFCF}_{2} \mathrm{OCF}_{2} \mathrm{CF}_{2} \mathrm{SO}_{2} \mathrm{~F}+\mathrm{n} \mathrm{CF}=\mathrm{CF}_{2} \rightarrow\left[-\left(\mathrm{CF}_{2} \mathrm{CF}\right)_{\mathrm{m}}-\left(\mathrm{CF}_{2} \mathrm{CF}_{2}-\right)_{\mathrm{n}}\right] \\
\mathrm{CF}_{2} \mathrm{OCF}_{2} \mathrm{CF}_{2} \mathrm{SO}_{2} \mathrm{~F}
\end{aligned}
$$

Equivalent weights ranging from 1200 to 1400 were found for the polymer, which was thermally stable to an excess of $300^{\circ} \mathrm{C}(34)$.

Developmental work at Tokuyama Soda Company investigated copolymerization of three monomers; a perfluorodivinyl ether, a fluorovinyl ether and a perfluorocyclic compound: 
$\left(\mathrm{CF}_{2}=\mathrm{CFOCF}_{2}\right)_{2} \mathrm{CF} ; \quad \mathrm{CF}_{2}=\mathrm{CFOCF}_{2} \mathrm{CFCF}_{2} \mathrm{CFHCF}_{3}$ and $\mathrm{CF}_{2}=\mathrm{CFOCF}_{2} \mathrm{CFCF}_{2} \mathrm{OCFCF}_{3}$ $\mathrm{OCF}_{2} \mathrm{CF}_{2} \mathrm{SO}_{2} \mathrm{~F} \quad \mathrm{OCF}_{2} \mathrm{CF}_{2} \mathrm{SO}_{2} \mathrm{~F} \quad$ OCF $\mathrm{CF}_{2} \mathrm{SO}_{2}$

The composition of the polymer was not specified, but hydroIysis with 1 molar sodium hydroxide resulted in a sulfonate salt polymer with an equivalent weight of 560 (35).

OTHER ROUTES TO POLYMERS

WITH FLUOROALKYL SULFONYL FLUORIDE GROUPS OR DERIVATIVES

Development of polymers containing fluoroalkyl sulfonyl fluoride groups or derivatives is not limited to reactions involving copolymerization of fluoro-olefins and fluorovinyl ethers. Literature reports include copolymerization of an acid fluoride with tetrafluoroethylene, polymerization of allyl alcohol esters and grafting of fluoroalkly sulfonyl compounds to existing non-fluorinated polymers.

\section{Copolymerization of an Acid Fluoride}

A perfluoro polymer having a fluorosulfonyl side-chain group and ether linkages in the main polymer chain was prepared from fluorosulfonyl difluoroacetyl fluoride and tetrafluoroethylene under free-radical conditions in solution:

$$
\left.m \mathrm{FC}(\mathrm{O}) \mathrm{CF}_{2} \mathrm{SO}_{2} \mathrm{~F}+n \mathrm{CF}_{2}=\mathrm{CF}_{2} \longrightarrow \underset{\mathrm{CF}_{2} \mathrm{SO}_{2} \mathrm{~F}}{\left[-(\mathrm{CF}-\mathrm{O}-)_{\mathrm{m}}\right.}\left(-\mathrm{CF}_{2}-\mathrm{CF}_{2}-\right)_{\mathrm{n}}\right]
$$


As reported by the group at Tejin Limited, the polymer was formed in $71 \%$ yield and contained 37 mole\% $-\mathrm{CF}\left(\mathrm{CF}_{2} \mathrm{SO}_{2} \mathrm{~F}\right)-$ units (36). This indicates practically a one-to-one ratio of monomers, giving an equivalent weight of 250 . Conversion of the sulfonyl fluoride group to a salt or acid was not described so the solubility of the polymer cannot be addressed.

\section{Polymerization of Allyl Alcohol Esters}

Although the polymers described by Terjeson et al. are not based on a fluorinated polymer chain, theirs is the only work reported involving reactions of compounds possessing pentafluorosulfur groups (13).

Monomers were prepared using allyl alcohol and fluorinated $B$-sultones:

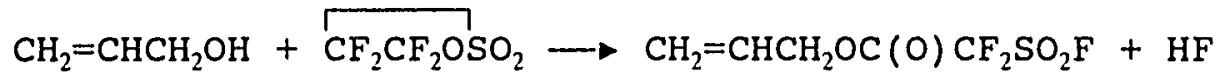

$\mathrm{CH}_{2}=\mathrm{CHCH}_{2} \mathrm{OH}+\mathrm{SF}_{5} \mathrm{CXCF}_{2} \mathrm{OSO}_{2} \mathrm{~F} \rightarrow \operatorname{SO}_{2} \mathrm{~F}$ $\mathrm{X}=\mathrm{F}, \mathrm{H}$

Polymerization of the esters under ultraviolet light resulted in viscous oils and solid waxy products obtained in yields ranging from 44 to $100 \%$ :

$$
n \mathrm{CH}_{2}=\mathrm{CHCH}_{2} \mathrm{OC}(\mathrm{O}) \mathrm{CF}_{2} \mathrm{SO}_{2} \mathrm{~F} \stackrel{h V}{\longrightarrow}-\left(\mathrm{CH}_{2}-\mathrm{CH}-\right)_{n}
$$




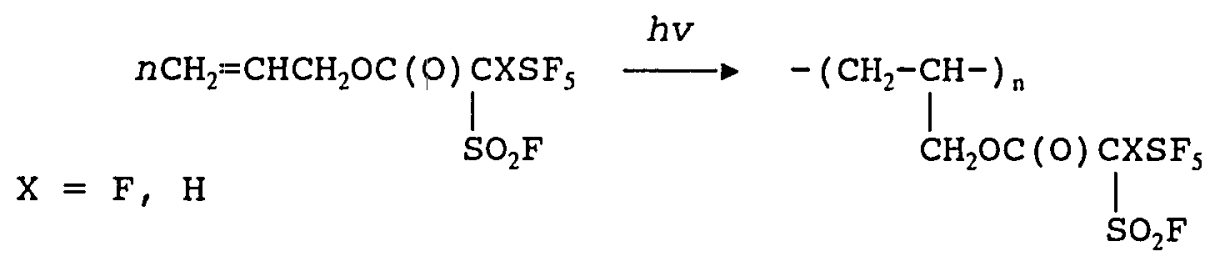

These polymers possessed poor thermal stability, decomposing in the range of 150 to $170^{\circ} \mathrm{C}$.

Fluoroalkyl sulfonyl Fluorides and Pre-existing Polymers

Two methods have been reported for incorporating fluoroalkyl sulfonyl fluoride groups into pre-existing polymers. The first method involves grafting 1,1,2,2tetraflucroethane sulfonyl fluoride onto polyethylene under ultraviolet light as reported by Momose et al. (37):

$$
\left(-\mathrm{CH}_{2}-\mathrm{CH}_{2}-\right)_{\mathrm{n}}+\mathrm{mHCF}_{2} \mathrm{CF}_{2} \mathrm{SO}_{2} \mathrm{~F} \stackrel{\mathrm{hV}}{\longrightarrow}\left(-\mathrm{CH}_{2}-\underset{\mathrm{CF}_{2} \mathrm{CF}_{2} \mathrm{SO}_{2} \mathrm{~F}}{\mathrm{CH}-)_{\mathrm{m}}}\left(-\mathrm{CH}_{2}-\mathrm{CH}_{2}\right)_{\mathrm{n}-\mathrm{m}}\right.
$$

No characterization of equivalent weight, thermal stability or surface versus bulk incorporation of the sulfonyl fluoride group was reported. The second method described by Terjeson and coworkers involves grafting of $B-f l u o r o s u l t o n e s$ to polyvinyl alcohol forming ester linkages between the polymer chain and the sulfonyl fluoride (13): 


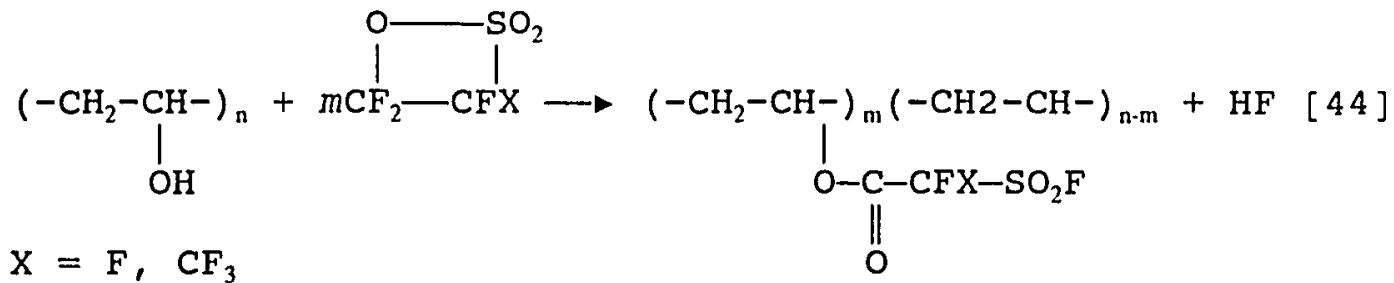

Yields of products incorporating the fluorinated groups ranged from 29 to $30 \%$. The products decomposed at relatively low temperatures (123 to $\left.170^{\circ} \mathrm{C}\right)$. As with their work involving allyl alcohol discussed above, compounds possessing sulfur pentafluoride groups were investigated as well. However, no polymeric materials containing the $\mathrm{SF}_{5}$ group could be isolated. 
CHAPTER III

EXPERIMENTAL METHODS

VACUUM SYSTEMS

\section{Glass System}

The glass vacuum system used with all gases except hydrogen fluoride consisted of a manifold connected to a Welch Dou-Seal rotary pump. The manifold was constructed of $8 \mathrm{~mm}$ and $22 \mathrm{~mm}$ I.D. Pyrex glass connected to the pump by a concentric liquid nitrogen cooled trap. The manifold had four Kontes high vacuum stopcocks to which $10 / 30$ standard taper female joints were attached. Pressure was monitored using a two leg mercury manometer or a Felevac thermocouple gauge. All joints were lubricated with either Flourolube GR-290 or Apiezon-N greases. Pressures of $10^{-2}$ torr or less were usually obtained.

\section{Metal System}

Work involving anhydrous hydrogen fluoride was performed using a manifold constructed of $3 / 8$ inch refrigeration grade copper tubing. Four Whitey Monel stopcocks fitted with female 10/30 standard taper copper joints were attached by brazing with silver solder. All other connections were made using copper compression fittings. The manifold was connected to a Welch Dou-seal 
rotary pump through a concentric liquid nitrogen cooled trap. Pressure was monitored with an ACCD Helicoid Gage vacuum gauge. Pressures of 1 torr or less were obtained.

\section{ELECTROCHEMICAL FLUORINATION SYSTEM}

The reaction cell consisted of a $60 \mathrm{ml}$ PFA Teflon digestion vessel with molded ferrule fittings. Cylindrical electrodes (anode $22 \mathrm{~cm}^{2}$, cathode $11 \mathrm{~cm}^{2}$ ) were fabricated using 40 gauge nickel mesh. Current was supplied using an EE\&G Princeton Applied Research model 363 potentiostat operating with controlled potential. The cell was fitted with a copper reflux condenser followed by a concentric liquid nitrogen cooled trap and a mercury bubbler. Reflux temperature was obtained using a Lauda circulating thermostat using a methanol/water coolant. Anhydrous hydrogen fluoride was directly introduced in the liquid state.

\section{PHOTOINITIATED POLYMERIZATION SYSTEM}

Photoinitiated polymerizations were performed using a 450 watt Hanovia mercury lamp cooled by a quartz jacket. The lamp was mounted in a horizontal position under a parabolic aluminum reflector. The lamp and reflector were housed in a box fashioned from $3 / 4$ inch RMP board with a white melamine interior. The distance from the center axis of the lamp to the irradiated surface was 10 inches. 
REACT:LON VESSELS

Pyrex-glass Vessels

Low temperature or low / pressure reactions were

performed in 75 to $100 \mathrm{ml}$ Pyrex-glass vessels equipped with

$2 \mathrm{~mm}$ high vacuum Kontes Teflon stopcocks fitted with male 10/30 standard taper joints. Moderate temperature or pressure reactions were performed using heavy walled Pyrexglass Carius tubes fitted with similar stopcocks and joints.

\section{Metal High pressure Vessels}

High pressure reactions were performed using 25 to 75 ml stainless steel vessels equipped with whitey stainless steel valves fitted with male 10/30 standard taper brass joints.

\section{PHYSICAL METHODS AND INSTRUMENTATION}

\section{Distillation}

Liquid products were purified by short path distillation at atmospheric pressure or under vacuum with a liquid nitrogen cooled trap to collect volatile products.

\section{Vapor Phase Chromatography}

Analysis of purity or separation of products determined by VPC was performed using an Aerograph Autoprep model A-700 gas chromatograph. Separations were carried out using a $10^{\prime} \times 3 / 8 "$ column containing $20 \%$ Carbowax on Chromosorb $W$. 


\section{Infrared spectroscopy}

Infrared spectra were obtained on potassium bromide, sodium chloride, silver chloride or KRS-5 plates for liquids and solids using a Nicolet 20 DX spectrometer. Gas spectra were obtained using a $10 \mathrm{~cm}$ path length Pyrex cell fitted with a Kontes Teflon high vacuum stopcock and sodium chloride or KRS-5 windows.

\section{Nuclear Magnetic Resonance}

NMR spectra were recorded with a Varian model EM-390 spectrometer operating at $90.0 \mathrm{MHz}$ for proton and $84.67 \mathrm{MHz}$ for fluorine resonances or on a Bruker AMX400 spectrometer operating at $400 \mathrm{MHz}$ for proton, $376.5 \mathrm{MHz}$ for fluorine-19 and $100.6 \mathrm{MHz}$ for carbon-13 resonances.

\section{Mass Spectrometry}

Mass spectra were recorded with Varian MAT CH5 and Finnigan MAT 8230 systems operating at $30 \mathrm{eV}$ or a HewlettPackard HP58901 Series II gas chromatograph with a 5970 mass selective detector utilizing a 15 meter $D B-5$ column.

\section{Elemental Analysis}

Elemental analyses were determined by Beller Mikroanalytisches Laboratorium, Gottingen, Germany.

\section{Melting Point}

Melting points were determined using a Mel-Temp capillary melting point apparatus. Temperatures are 
uncorrected.

\section{Refractive Index}

Refractive indices were determined using a Bausch \& Lomb Abbe-31 refractometer at ambient temperatures.

\section{Contact Angle}

Contact angles were obtained using a Kayness model 1060 contact angle analyzer.

\section{Conductivity Measurements}

Conductivity measurements were determined by Dr. M.M. Lerner, Department of Chemistry and Center for Advanced Materials Research, Oregon State University, Corvallis, oregon.

\section{REAGENTS AND SOLVENTS}

The following specialty chemicals were obtained from commercial sources and used without further purification except where noted in the Experimental sections of CHAPTERS IV and $\mathrm{V}: \mathrm{CF}_{2}=\mathrm{CF}_{2}, \quad\left(\mathrm{CF}_{3}\right)_{2} \mathrm{C}=\mathrm{O}, \mathrm{CF}_{3} \mathrm{C}(\mathrm{O}) \mathrm{CF}_{2} \mathrm{Cl}, \mathrm{CF}_{3} \mathrm{C}(\mathrm{O}) \mathrm{O}(\mathrm{O}) \mathrm{CCF}_{3}$, $\mathrm{O}=\mathrm{CCF}_{2} \mathrm{CF}_{2} \mathrm{C}_{\mathrm{F}} 2 \mathrm{C}=\mathrm{O}$ ，(PCR, InC.); $\mathrm{HF}, \mathrm{BF}_{3}$ ， (Matheson Gas Products); $\mathrm{C}_{6} \mathrm{H}_{5} \mathrm{CH}_{2} \mathrm{OH}, \mathrm{C}_{6} \mathrm{H}_{5} \mathrm{OH}, \mathrm{Br}_{2},(\mathrm{MCB}) ; \mathrm{LiOH} \cdot \mathrm{H}_{2} \mathrm{O}$ ， $\mathrm{CH}_{2}=\mathrm{CHC}(\mathrm{O}) \mathrm{OH}, \mathrm{O}=\mathrm{C}=\mathrm{NCH}_{2} \mathrm{CH}_{2} \mathrm{CH}_{2} \mathrm{CH}_{2} \mathrm{CH}_{2} \mathrm{CH}_{2} \mathrm{~N}=\mathrm{C}=\mathrm{O}$, Dowex $50 \mathrm{~W}-\mathrm{X} 12$ cation exchange resin, Nafion NR50 beads 10-50 mesh, $\mathrm{SO}_{3}$ trimer, (Aldrich); $\mathrm{CH}_{2}=\mathrm{CHC}(\mathrm{O}) \mathrm{ONa},($ Pfaltz \& Bauer); $\mathrm{N} \equiv \mathrm{CC}\left(\mathrm{CH}_{3}\right)_{2} \mathrm{~N}=\mathrm{NC}\left(\mathrm{CH}_{3}\right)_{2} \mathrm{C} \equiv \mathrm{N},(\mathrm{ICN}) ; \mathrm{I}_{2}, \mathrm{NaF}$, (Mallinckrodt); 
$\mathrm{SO}_{3}$ as oleum (DuPont), $\mathrm{Al}_{2} \mathrm{O}_{3}, \mathrm{CaO}, \mathrm{CsF}$, (J.T. Baker); $\mathrm{AgF}$, (Pennwalt); UVI-6974 and CYRACURE UVR-6110 were gifts from Radcure Specialties.

The intermediate reactants; $\mathrm{CH}_{2} \mathrm{CHCH}_{2} \mathrm{OCF}_{2} \mathrm{CF}_{2} \mathrm{SO}_{2} \mathrm{~F}$, $\mathrm{CH}_{2}\left(\mathrm{OCF}_{2} \mathrm{CF}_{2} \mathrm{SO}_{2} \mathrm{~F}\right)_{2}, \quad \mathrm{BrCH}_{2} \mathrm{CH}_{2} \mathrm{OCF}_{2} \mathrm{CF}_{2} \mathrm{SO}_{2} \mathrm{~F}$ ， $\mathrm{SF}_{5} \mathrm{CFHSO}_{2} \mathrm{~F}, \mathrm{SF}_{5} \mathrm{CF}_{2} \mathrm{SO}_{2} \mathrm{~F}$ ， $\mathrm{HOCH}_{2} \mathrm{CH}_{2} \mathrm{CF}_{2} \mathrm{CF}_{2} \mathrm{OCF}_{2} \mathrm{CF}_{2} \mathrm{SO}_{2} \mathrm{~F}, \mathrm{FC}(\mathrm{O}) \mathrm{CF}_{2} \mathrm{SO}_{2} \mathrm{~F}$ and $\mathrm{CF}_{2} \mathrm{CF}_{2} \mathrm{OSO} \mathrm{O}_{2}$ were prepared according to literature procedures (38-43). All solvents, other than deuterated solvents for NMR and freshly opened analytical grades, were purified according to literature procedures prior to use (44). 
CHAPTER IV

SIMPLE FLUOROALKYL SULFONYL FLUORIDES, SULFONATE SALTS AND SULFONIC ACIDS

The utilization of fluorocarbon sulfonyl fluorides and derivatives as ion exchange resins, surface active agents and in the production of strong sulfonic acids makes them the subject of considerable interest. As mentioned in CHAPTER I, fluoroalkyl sulfonic acids and lithium sulfonate salts are also being investigated for possible use in fuel cells and lithium batteries.

The preparation of new fluoroalkyl sulfonyl fluorides, sulfonate salts and sulfonic acids discussed in this chapter resulted in compounds with increased fluorine content, branching in the alkyl chain and the incorporation of the $\mathrm{SF}_{5}$ functional group.

\section{INCREASING FLUORINE CONTENT}

Several desirable properties of fluoroalkyl sulfonic acids for use as fuel cell electrolytes are enhanced as the fluorine content in these compounds is increased. In this work, highly fluorinated and perfluorinated fluoroalkylsulfonyl fluorides, sulfonate salts and a disulfonic acid were prepared using electrochemical fluorination, while a 
branched fluoroalkyl sulfonyl fluoride was synthesized utilizing a reaction incorporating the perfluoroisopropyl group.

\section{Electrochemical Fluorination}

Electrochemical fluorination was developed by Joseph Simons at the 3M Company in the mid 1940's. The Simons process involves electrolyzing organic compounds dissolved or dispersed in anhydrous hydrogen fluoride. Typically, nickel electrodes are used. Partial loss of product due to carbon chain rearrangement and decomposition is usually observed in this process; this loss is less severe when the chain length and the number of hydrogens to be replaced are small. Simons electrochemical fluorination is used commercially as a synthetic route to many highly fluorinated and perfluorinated organic compounds including alkanes, ethers, ketones, amines, carbonyl fluorides and alkylsulfonyl fluorides $(45,46)$.

Although the mechanism for this reaction is not completely understood, it is believed to involve carbocation intermediates and high-valence nickel fluoride species in a four step electrochemical/chemical/electrochemical/chemical (ECEC) reaction $(46,47)$ :

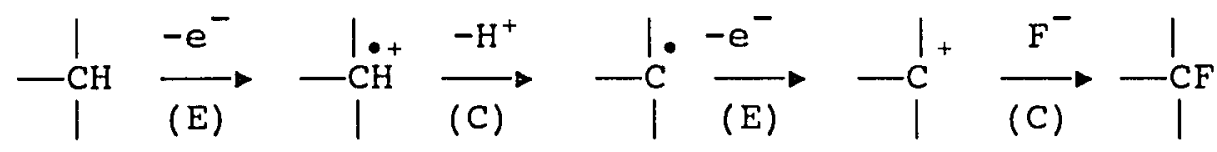


In the first electrochemical step, the reactant is oxidized to a radical cation which then under goes an acid-base chemical reaction. The resulting neutral radical is again electrochemically oxidized to give a carbocation which undergoes nucleophilic addition by fluoride ion. The exact nature of the source of fluoride ion is not understood, but is believed to be from a high-valence nickel fluoride species formed on the anode. Hydrogen is evolved at the cathode by reduction of the liberated protons.

As a route to synthesizing totally fluorinated alkyl sulfonyl fluorides, sulfonate salts and sulfonic acids, an electrochemical fluorination cell was designed and built inhouse to prepare from $\mathrm{CH}_{2}\left(\mathrm{OCF}_{2} \mathrm{CF}_{2} \mathrm{SO}_{2} \mathrm{~F}\right)_{2}$ (I), the new fluorinated sulfonyl fluorides $\mathrm{CHF}\left(\mathrm{OCF}_{2} \mathrm{CF}_{2} \mathrm{SO}_{2} \mathrm{~F}\right)_{2}$ (II), and $\mathrm{CF}_{2}\left(\mathrm{OCF}_{2} \mathrm{CF}_{2} \mathrm{SO}_{2} \mathrm{~F}\right)_{2}$ (III):

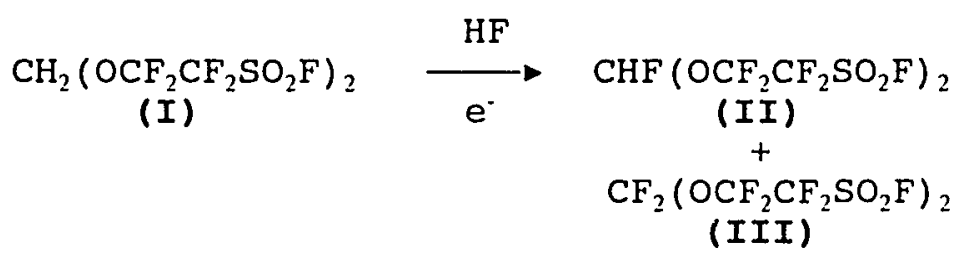

The high boiling liquid products were obtained in $19 \%$ and $16 \%$ yields, respectively, based on coulombs of charge used during fluorination.

The fluoroalkyl sulfonyl fluorides (I) and (III) undergo basic hydrolysis to give stable calcium and sodium sulfonate salts: 
$\mathrm{CH}_{2}\left(\mathrm{OCF}_{2} \mathrm{CF}_{2} \mathrm{SO}_{2} \mathrm{~F}\right)_{2}+4 \mathrm{NaOH} \rightarrow \mathrm{CH}_{2}\left(\mathrm{OCF}_{2} \mathrm{CF}_{2} \mathrm{SO}_{3} \mathrm{Na}\right)_{2}+2 \mathrm{NaF}+2 \mathrm{H}_{2} \mathrm{O}$ (I) (IV) $\underset{(\mathrm{III})}{\mathrm{CF}_{2}\left(\mathrm{OCF}_{2} \mathrm{CF}_{2} \mathrm{SO}_{2} \mathrm{~F}\right)_{2}}+2 \mathrm{Ca}(\mathrm{OH})_{2} \rightarrow \underset{\text { (V) }}{\mathrm{CF}_{2}\left(\mathrm{OCF}_{2} \mathrm{CF}_{2} \mathrm{SO}_{3}\right)_{2} \mathrm{Ca}}+\mathrm{CaF}_{2}+2 \mathrm{H}_{2} \mathrm{O}$

These salts were stable to high temperatures with (IV) clecomposing at a lower temperatures than ( $V$ ) and possibly liberating $H F$ as suggested by etching of the glass melting point capillary tube.

Attempts to prepare the sulfonic acids $\mathrm{CH}_{2}\left(\mathrm{OCF}_{2} \mathrm{CF}_{2} \mathrm{SO}_{3} \mathrm{H}\right)_{2}$ and $\mathrm{CF}_{2}\left(\mathrm{OCF}_{2} \mathrm{CF}_{2} \mathrm{SO}_{3} \mathrm{H}\right)_{2}$ from the corresponding salts by distillation from sulfuric acid failed. For $\mathrm{CH}_{2}\left(\mathrm{OCF}_{2} \mathrm{CF}_{2} \mathrm{SO}_{3} \mathrm{Na}\right)_{2}$, the acid labile acetal group may have been hydrolyzed giving an unstable $\alpha$-fluoro alcohol, which then lost hydrogen fluoride to give the acid fluoride:

$$
\begin{gathered}
\underset{\quad \mathrm{CH}_{2}\left(\mathrm{OCF} \mathrm{CF}_{2} \mathrm{SO}_{3} \mathrm{Na}\right)_{2}}{(\mathrm{IV})} \stackrel{\mathrm{H}^{+}}{\mathrm{H}_{2} \mathrm{O}} \longrightarrow 2 \mathrm{HOCF}_{2} \mathrm{CF}_{2} \mathrm{SO}_{3} \mathrm{Na}+\mathrm{CH}_{2}=\mathrm{O} \\
\mathrm{HOCF}_{2} \mathrm{CF}_{2} \mathrm{SO}_{3} \mathrm{Na} \\
\longrightarrow \mathrm{FC}(\mathrm{O}) \mathrm{CF}_{2} \mathrm{SO}_{3} \mathrm{Na}+\mathrm{HF}
\end{gathered}
$$

while with $\mathrm{CF}_{2}\left(\mathrm{OCF}_{2} \mathrm{CF}_{2} \mathrm{SO}_{3} \mathrm{H}\right)_{2}$ formation of a tarry brown residue in the still pot resulted. However, using a strong cation exchange column the hydrated acid, $\mathrm{CF}_{2}\left(\mathrm{OCF}_{2} \mathrm{CF}_{2} \mathrm{SO}_{3} \mathrm{H}\right)_{2} \cdot \mathrm{nH}_{2} \mathrm{O}$ (VI), was formed in good yield as a clear oily liquid:

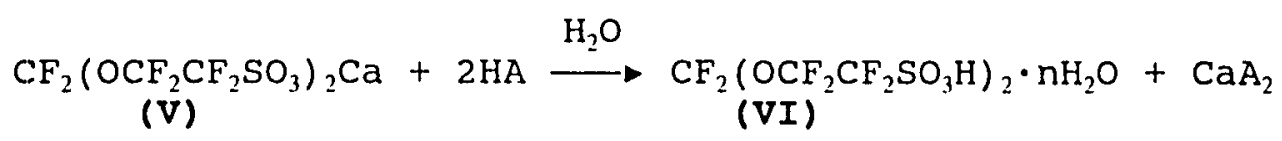


where $\mathrm{HA}=$ cation exchange resin in protonated form and $\mathrm{CaA}_{2}=$ resin with exchanged calcium cation.

Complete IR and mass spectra data for these compounds may be found in the Experimental section of this chapter. The ${ }^{19} \mathrm{~F}$ nmr spectrum of $\mathrm{CHF}\left(\mathrm{OCF}_{2} \mathrm{CF}_{2} \mathrm{SO}_{2} \mathrm{~F}\right)_{2}$ (II) (TABLE I) is interesting in two respects; the CHF resonance is shifted downfield, $\phi=-88.9 \mathrm{ppm}$, from the usual region for geminal $\mathrm{H}-\mathrm{F}$ groups in fluorohydrocarbons (48), and the $\mathrm{OCF}_{2}$ group appears as an $A B$ portion of the spin system with resonances at $\phi=-82.4$ and $\phi=-84.3 \mathrm{ppm}$ with a coupling of $145 \mathrm{~Hz}$. The deshielding of the CHF group may be attributable to electron withdrawal by neighboring oxygens. The $A B$ pattern of the $\mathrm{OCF}_{2}$ group is consistent with the diastereotopic nature of these two fluorines.

In other compounds containing perfluoroacetal groups a fluorine resonance at $\phi=-55.3 \mathrm{ppm}$ was attributed to the -OCF $\mathrm{CF}_{2} \mathrm{group}(49)$. For (III), (V) and (VI), (TABLE I), these resonances were found at $\phi=-51.4,-51.2$ and -51.6 ppm respectively. The chemical shifts for the $\mathrm{CF}_{2} \mathrm{SO}_{2} \mathrm{~F}$ groups in (II) and (III) agree with values found for the similar groups in $\mathrm{FSO}_{2}\left(\mathrm{CF}_{2}\right)_{3} \mathrm{SO}_{2} \mathrm{~F}(50)$. In the salts and acid, (IV), (v) and (VI), the $\mathrm{CF}_{2} \mathrm{SO}_{3}$ resonances were found at similar chemical shifts of $\phi=-118.0,-119.3$ and $-120.2 \mathrm{ppm}$ respectively.

For the perfluorinated compounds (III), (V) and (VI), the magnitude of the coupling between the $\mathrm{OCF}_{2} \mathrm{O}$ and $\mathrm{OCF}$ ? 
groups was similar with values ranging from 10.6 to $11.6 \mathrm{~Hz}$. However, coupling between the $\mathrm{OCF}_{2}$ and $\mathrm{CF}_{2} \mathrm{~S}$ groups in (III) was found to be $6.1 \mathrm{~Hz}$ while in the salt (V) and acid (VI) no measurable coupling was observed. No coupling between these groups was observable the sodium salt (IV) (TABLE I). The NMR chemical shifts and coupling constants/for the other groups fall in the ranges of previously reportied values for related compounds $(48,51,52)$.

\section{TABLE I}

${ }^{19} \mathrm{~F}$ AND 'H NMR DATA FOR COMPOUNDS CHF (OCF2CF2SO2F) 2 (II), CF2 (OCF2CF2SO2F) 2 (III), $\mathrm{CH} 2$ (OCF2CF2SO3) $2 \mathrm{Na} 2$ (IV), [CF2 (OCF2 $\left.\left.\mathrm{CF} 2 \mathrm{SO}_{3}\right) 2\right] \mathrm{Ca}$ (V) AND $\mathrm{CF} 2(\mathrm{OCF} 2 \mathrm{CF} 2 \mathrm{SO} 3 \mathrm{H}) 2$ (VI)

\begin{tabular}{|c|c|c|c|}
\hline $\mathrm{CXY}^{\mathrm{a}}$ & $O C F 2^{b \& b^{\prime}}$ & $\mathrm{CF} 2^{\mathrm{c}}$ & $\mathrm{SO}_{2} \mathrm{~F}^{\mathrm{d}}$ \\
\hline $\begin{array}{l}\text { CHF (OCF2CF2SO } \\
F-88.9(\mathrm{~d}, \mathrm{p}) \\
\mathrm{H} 7.0 \quad(\mathrm{~d}) \\
J H^{\mathrm{a}}-F^{a}=63.4 \\
J F^{\mathrm{a}}-F^{b \& b^{b}}=6.2\end{array}$ & 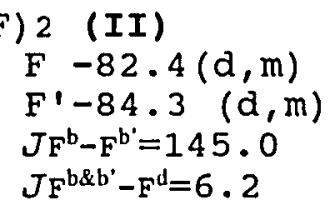 & $\begin{array}{l}-112.8(\mathrm{~m}) \\
J F^{\mathrm{c}}-F^{d}=6.2\end{array}$ & $45.0(t, t)$ \\
\hline $\begin{array}{l}C F 2 \text { (OCF2CF2SO } \\
F-51.4 \quad(p) \\
J F^{a}-F^{b \& b^{\prime}}=10.6\end{array}$ & $\begin{array}{l}2 \quad(I I I) \\
-84 \cdot 0 \quad(m) \\
J F^{b \& b^{b}}-F^{c}=6.1\end{array}$ & $\begin{array}{l}-112.6 \quad(d, t) \\
J F^{c}-F^{d}=6.1\end{array}$ & $45.6(t, t)$ \\
\hline $\begin{array}{l}\mathrm{CH} 2 \text { (OCF } 2 \text { CF } 2 \mathrm{SO} \\
\mathrm{H} \quad 5.2(\mathrm{~s})\end{array}$ & $\begin{array}{l}2 \mathrm{Na} 2 \quad(\mathrm{IV}) \\
-85.0 \quad(\mathrm{~S}) \\
J \mathrm{~F}^{\mathrm{b} \& b^{b}-F^{c}<1.5}\end{array}$ & $-118.0 \quad(\mathrm{~s})$ & \\
\hline
\end{tabular}


TABLE I

${ }^{19} \mathrm{~F}$ AND 'H NMR DATA' FOR COMPOUNDS CHF(OCF2CF2SO2F) 2 (II), $\mathrm{CF} 2(\mathrm{OCF} 2 \mathrm{CF} 2 \mathrm{SO} 2 \mathrm{~F}) 2$ (III), $\mathrm{CH} 2(\mathrm{OCF} 2 \mathrm{CF} 2 \mathrm{SO} 3$ ) $2 \mathrm{Na} 2$ (IV), [CF2 (OCF2CF2SO3) 2 ] Ca (V) AND $\mathrm{CF} 2(\mathrm{OCF} 2 \mathrm{CF} 2 \mathrm{SO} 3 \mathrm{H}) 2$ (VI)*

continued

\begin{tabular}{llll}
\hline $\mathrm{CXY}^{\mathrm{a}}$ & $\mathrm{OCF}^{\mathrm{b} \& \mathrm{~b}^{\prime}}$ & $\mathrm{CF}^{\mathrm{c}}$ & $\mathrm{SO} 2 \mathrm{~F}^{\mathrm{d}}$ \\
\hline
\end{tabular}

[CF2 (OCF2 $\left.\left.\mathrm{CF}_{2} \mathrm{SO}_{3}\right) 2\right] \mathrm{Ca}:(\mathrm{v})$

$\mathrm{F}-51.2(\mathrm{~m}) \quad-85.2(\mathrm{t}) \quad-119.3(\mathrm{~s})$

$\mathrm{CF} 2\left(\mathrm{OCF} 2 \mathrm{CF} 2 \mathrm{SO} 3 \mathrm{H}^{* *}\right) 2$ (VI)

$\mathrm{F}-51.6$ (p) $\quad-85.3$ (t) $\quad-120.2$ (s) $\cdots$

$J F^{a}-F^{b \& b^{\prime}}=11.6$

"Chemical shifts in ppm; coupling constants in $\mathrm{Hz}$. " Chemical shift $=10.8$ in $\mathrm{CD}_{3} \mathrm{CN}$. " Broad signal.

The ${ }^{13} \mathrm{C}$ NMR protion decoupled spectra of compounds (I), (II), (III), (IV) and (VI), (TABLE II) show variations in the coupling between the $\mathrm{OCF}_{2}$ fluorines and the acetal carbon. Values of $5.3,4.9$ and $5.8 \mathrm{~Hz}$ were obtained for (I), (II) and (IV), respectively, while with the perfluoro compounds (III) and (VI) no similar coupling was observed. The ${ }^{13} \mathrm{C}$ NMR proton coupled spectrum of the $\mathrm{CH}_{2}$ group in (I) and (IV) was found to have the expected triplet-pentet pattern with a coupling of 178.8 and $177.4 \mathrm{~Hz}$, respectively; for (II) the CHF group exhibited a d,d,p pattern with a 'JC-H value of $214.8 \mathrm{~Hz}$. 
TABLE II

${ }^{13} \mathrm{C}$ NMR DATA FOR COMPOUNDS CH2(OCF2CF2SO2F) 2 (I), $\mathrm{CHF}(\mathrm{OCF} 2 \mathrm{CF} 2 \mathrm{SO} 2 \mathrm{~F}) 2$ (II), $\mathrm{CF} 2(\mathrm{OCF} 2 \mathrm{CF} 2 \mathrm{SO} 2 \mathrm{~F}) 2$ (III), $\mathrm{CH} 2(\mathrm{OCF} 2 \mathrm{CF} 2 \mathrm{SO} 3$ ) $2 \mathrm{Na} 2$ (IV) AND CF2 (OCF2CF2SO3H) 2 (VI)

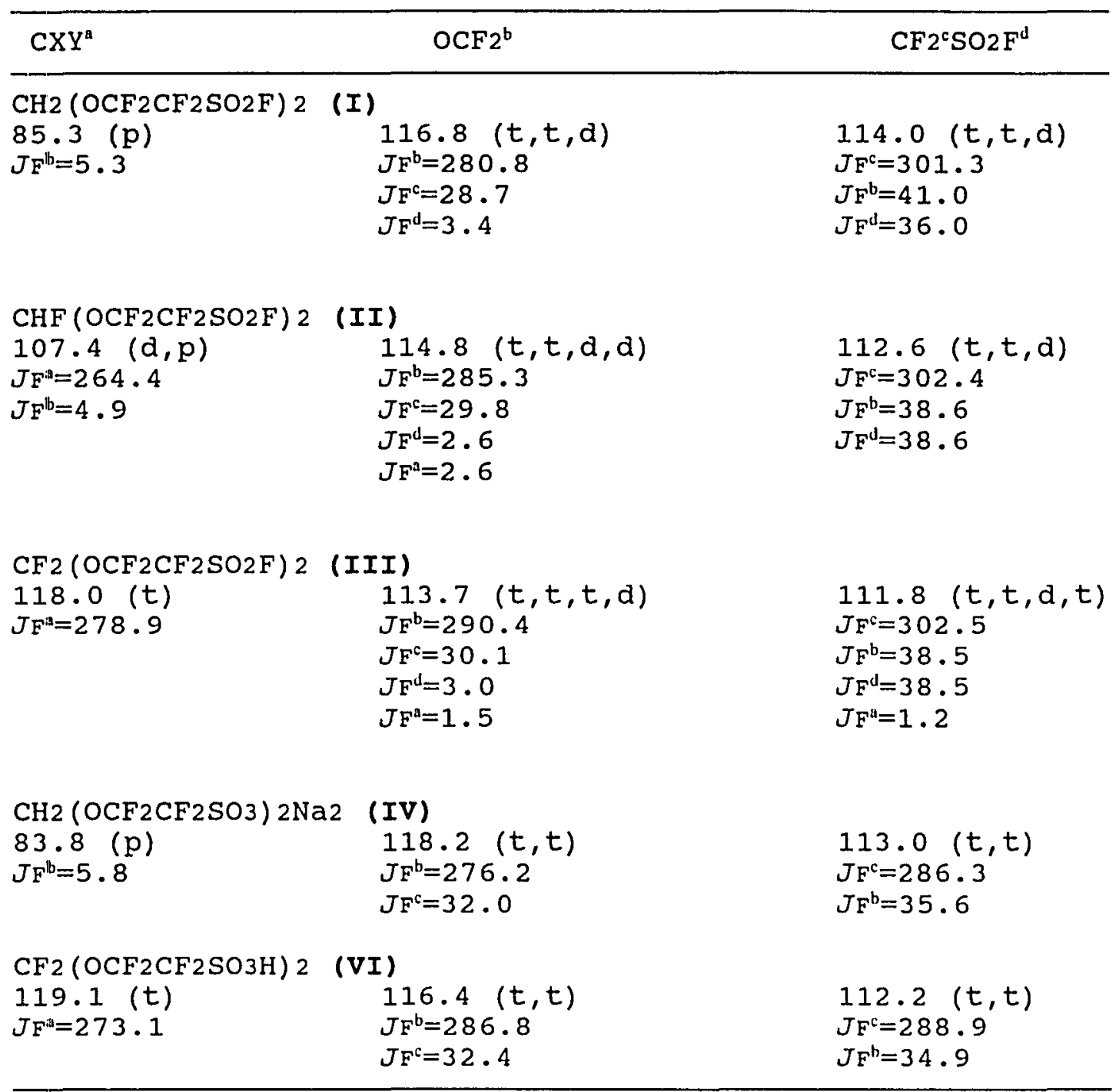

'Chemical shifts in ppm; coupling constants in $\mathrm{Hz}$. Splitting patterns listed for (I), (II), (IV) and (VI) are for proton-decoupled spectra. In the coupled spectra, the following splitting patterns and coupling constants were found: (I), CH2 (t,p), JH $H^{\mathrm{a}}=178.8$ and $\mathrm{OCF}_{2}(t, t, d, t), J H^{\mathrm{a}}=5.3$ $\mathrm{Hz} ;(I I), \operatorname{CHF}(d, d, p), J H^{a}=214.8$ and $\mathrm{OCF}_{2}(t, t, d, d, d)$, $J H^{\mu}=2.6 \mathrm{~Hz} ;(I V), \mathrm{CH}_{2}(t, p), J \mathrm{H}^{\mathrm{a}}=177.4$ and $\mathrm{OCF}_{2}(t, t, t)$ $J H^{\mathrm{b}}=5.0$. 
The infrared spectra of the new compounds, given in the APPENDIX, have common features. The characteristic $\mathrm{SO}_{2}$ asym and $\mathrm{SO}_{2}$ sym stretching frequencies were found for the sulfonyl fluorides (II) and (III) in the 1466-1464 and 1246-1245 $\mathrm{cm}^{-1}$ regions, respectively. The strong $\mathrm{S}-\mathrm{F}$ absorptions in these compounds, which are not present in the salts and acid, were seen at 804 and $809 \mathrm{~cm}^{-1}$. These assignments agree well with the results obtained in other fluorosulfonyl derivatives (51-53). The asym and sym $\mathrm{SO}_{3}$ stretching bands of the salts (IV) and (V) were found in the 1250-1267 and 1054-1032 $\mathrm{cm}^{-1}$ regions. For salts containing the $\mathrm{CF}_{3} \mathrm{SO}_{3}^{-}$group, the corresponding assigned regions are 1270-1290 and 1036-1038 $\mathrm{cm}^{-1}(53)$. The corresponding bands for the hydrated acid (VI) appeared in the 1250-1103 $\mathrm{cm}^{-1}$ range along with broad $\mathrm{OH}$ envelopes at 3458 and $1750 \mathrm{~cm}^{-1}$. The strong carbon fluorine absorption bands found at 1040-1267 $\mathrm{cm}^{-1}$ can be attributed to the $\mathrm{CF}_{2}$ groups and was present in all the compounds (54).

In the mass spectra, molecular ions were not detected for any of these compounds. However, M-F and other appropriate fragments were found and are supportive of the assigned structures.।

\section{Reactions with Fluorinated Species}

A literature review of reactions involving the fluorinated carbanyl group showed that fluorinated ketones 
and acid fluorides are very useful synthons for introducing highly fluorinated groups into organic compounds. The formation of adducts using hexafluoroacetone and various metal fluorides in aprotic solvents was first reported by Evans et al. (55):

$\left(\mathrm{CF}_{3}\right)_{2}=\mathrm{O}+\mathrm{MF} \longrightarrow\left(\mathrm{CF}_{3}\right)_{2} \mathrm{CFOM}(\mathrm{M}=\mathrm{Cs}, \mathrm{K}$ or $\mathrm{Ag})$

Howard and coworkers reported polyfluoroketones participate in free-radical chain addition reaction with carbon-hydrogen bonds in many substrates including cycloalkanes and dioxanes (56):

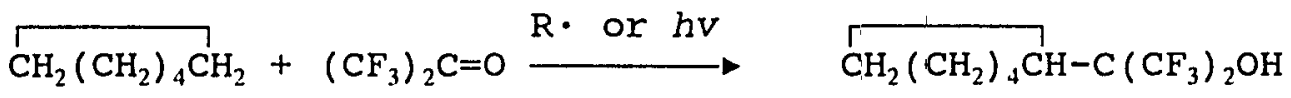

$$
\begin{aligned}
& \stackrel{+}{\mathrm{CH}_{2}\left(\mathrm{CH}_{2}\right)_{4} \mathrm{CH}}-\mathrm{OCH}\left(\mathrm{CF}_{3}\right)_{2}
\end{aligned}
$$

and

$\mathrm{OCH}_{2} \mathrm{CH}_{2} \mathrm{OCH}_{2} \mathrm{CH}_{2}+\left(\mathrm{CF}_{3}\right)_{2} \mathrm{C}=\mathrm{O} \stackrel{\mathrm{R}}{\longrightarrow} \overbrace{\mathrm{OCH}_{2} \mathrm{CH}_{2} \mathrm{OCH}} \mathrm{CH}-\mathrm{C}\left(\mathrm{CF}_{3}\right)_{2} \mathrm{OH}$

Graham and Weinmayr (57) found that tetrafluoroethylene (TFE) in the presence of metal fluorides will condense with perfluoro acid fluorides to give perfluoro tertiary alcohols through intermediate perfluoroketones via an additionelimination reaction:

$$
\mathrm{CF}_{3} \mathrm{C}(\mathrm{O}) \mathrm{F}+\mathrm{CF}_{2}=\mathrm{CF}_{2}+\mathrm{CsF} \longrightarrow \mathrm{CF}_{3}-\mathrm{CF}^{\mathrm{OCS}}-\mathrm{CF}_{2}-\mathrm{CF}_{3}
$$




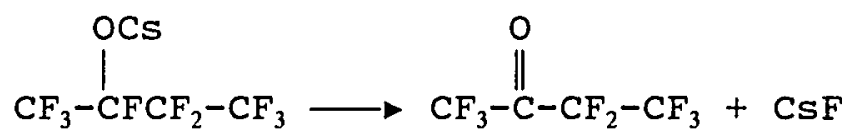

$\stackrel{O}{\|} \mathrm{CF}_{3}-\mathrm{C}-\mathrm{CF}_{2}-\mathrm{CF}_{3}+\mathrm{CF}_{2}=\mathrm{CF}_{2}+\mathrm{CsF} \longrightarrow \mathrm{CF}_{3}-\mathrm{C}_{\left(\mathrm{CF}_{2} \mathrm{CF}_{3}\right)_{2}}$

$\mathrm{CF}_{3}-\mathrm{C}\left(\mathrm{CF}_{2} \mathrm{CF}_{3}\right)_{2} \stackrel{\mathrm{HCl}}{\longrightarrow} \mathrm{CF}_{3}-\mathrm{C}_{\left(\mathrm{CF}_{2} \mathrm{CF}_{3}\right)_{2}+\mathrm{CsCl}}^{\mathrm{OH}}$

These reactions of polyfluorinated ketones suggested their use in the synthesis of branched fluorinated ethers, alcohols and ketones containing the $\mathrm{SO}_{2} \mathrm{~F}$ group.

Method 1. The formation of the adduct between silver fluoride and hexafluoroacetone was used to incorporate the perfluoroisopropoxide group into 5-bromo-1,1,2,2,-tetrafluoro-3-oxa-pentanesulfony fluoride:

$$
\begin{aligned}
&\left(\mathrm{CF}_{3}\right)_{2} \mathrm{C}=\mathrm{O}+\mathrm{AgF} \longrightarrow\left(\mathrm{CF}_{3}\right)_{2} \mathrm{CFOAg} \\
&\left(\mathrm{CF}_{3}\right)_{2} \mathrm{CFOAg}+\mathrm{BrCH} \mathrm{CH}_{2} \mathrm{OCF}_{2} \mathrm{CF}_{2} \mathrm{SO}_{2} \mathrm{~F} \longrightarrow \\
&\left(\mathrm{CF}_{3}\right)_{2} \mathrm{CFOCH}_{2} \mathrm{CH}_{2} \mathrm{OCF}_{2} \mathrm{CF}_{2} \mathrm{SO}_{2} \mathrm{~F}+\mathrm{AgBr} \\
&(\mathrm{VII})
\end{aligned}
$$

While the hexafluoroacetone-silver fluoride adduct gave a clear high boiling liquid product in $49 \%$ yield under conditions of mild temperature and pressure, the use of cesium fluoride resulted in only isolation of starting material. This trend in reactivity using metal fluorides 
has been observed in other reactions $(38,39,51)$.

Complete IR and mass spectra data for (VII) are presented in the Experimental section of this chapter. The ${ }^{1} \mathrm{H}$ NMR spectrum of (VII) (TABLE III) obtained at $60 \mathrm{MHz}$ was an unresolved $A_{2} B_{2}$ pattern with a chemical shift of $4.6 \mathrm{ppm}$. In the ${ }^{19} \mathrm{~F}$ NMR spectrum (TABLE III) resonances and coupling constants for the $\mathrm{OCF}_{2}, \mathrm{CF}_{2} \mathrm{~S}$, and $\mathrm{SO}_{2} \mathrm{~F}$ groups agree well with those values reported for $\mathrm{BrCH}_{2} \mathrm{CH}_{2} \mathrm{OCF}_{2} \mathrm{CF}_{2} \mathrm{SO}_{2} \mathrm{~F}$ (39). For the perfluoroisopropoxide group an unresolved resonance at -146.0 appeared for the Ione fluorine while a doublet at $81.0 \mathrm{ppm}$ with a coupling of $2.3 \mathrm{~Hz}$ was found for the $\left(\mathrm{CF}_{3}\right)_{2}$ group. Similar chemical shift values ranging from -137.4 to $-142.6 \mathrm{ppm}$ and -75.7 to $-78.8 \mathrm{ppm}$ for these groups with coupling of $2.0 \mathrm{~Hz}$ have been reported $(58-60)$.

TABLE III

${ }^{1} \mathrm{H}$ AND ${ }^{19} \mathrm{~F}$ NMR DATA FOR (CF3) $2 \mathrm{CFOCH}_{2} \mathrm{CH}_{2} \mathrm{OCF} 2 \mathrm{CF}_{2} \mathrm{SO}_{2} \mathrm{~F}$ (VII)

\begin{tabular}{lccccc}
\hline$\left(\mathrm{CF} 3^{\mathrm{a}}\right) 2$ & $\mathrm{CF} \mathrm{F}^{\mathrm{b}} \mathrm{O}$ & $\mathrm{OCH} 2 \mathrm{CH} 2 \mathrm{O}$ & $\mathrm{OCF}^{\mathrm{c}}$ & $\mathrm{CF} 2^{\mathrm{d} S}$ & $\mathrm{SO}_{2} F^{\mathrm{c}}$ \\
\hline$-81.0(\mathrm{~d})$ & $-146.0(\mathrm{~m})$ & $* *$ & $-86.5(d, t)$ & $-113.3(\mathrm{~d}, t)$ & $44.2(t, t)$ \\
$J F^{\mathrm{a}}-\mathrm{F}^{\mathrm{b}}=2.3$ & & & $J F^{\mathrm{c}}-\mathrm{F}^{\mathrm{d}}=5.1$ & $J F^{\mathrm{d}}-F^{\mathrm{c}}=5.6$ & $J F^{\mathrm{c}}-\mathrm{F}^{\mathrm{c}}=5.6$
\end{tabular}

"Chemical shifts in ppm; coupling constants in $\mathrm{Hz}$. "Unresolved A2B2 pattern at $4.6 \mathrm{ppm}$.

The infrared spectrum of (VII) revealed characteristic group frequencies similar to the starting material (39). The asymmetric and symmetric $\mathrm{SO}_{2}$ and $\mathrm{S}-\mathrm{F}$ stretches were found at 1458,1238 and $790 \mathrm{~cm}^{-1}$. Fluorocarbon groups were 
indicated by bands at 1049 to $1183 \mathrm{~cm}^{-1}$ and $\mathrm{CH}_{2}$ group bands occurring at 2975 and $2905 \mathrm{~cm}^{-1}$. Some notable differences supporting the displacement of bromine are the appearance of a new strong fluorocarbon band at $1124 \mathrm{~cm}^{-1}$ in (VII) and the absence of the $\mathrm{C}-\mathrm{Br}$ stretch at $581 \mathrm{~cm}^{-1}$ present in the starting material.

No molecular ion: was detected in the mass spectrum of (VII). Important fragments observed supporting the structure include; $\mathrm{M}-\mathrm{SO}_{2} \mathrm{~F}, \mathrm{M}-\left(\mathrm{CF}_{3}\right)_{2} \mathrm{FCO}$ and $\left(\mathrm{CF}_{3}\right)_{2} \mathrm{FC}$.

Method 2. In order to utilize a radical chain addition reaction of a fluoroketone, a suitable substrate possessing a minimum number of possibly labile sites was desired. The successful synthesis of $\mathrm{CH}_{3} \mathrm{OCF}_{2} \mathrm{CF}_{2} \mathrm{SO}_{2} \mathrm{~F}$ (IIX), gave an apparently suitable substrate:

$$
\begin{gathered}
\stackrel{\mathrm{CF}_{2} \mathrm{CF}_{2} \mathrm{OSO}_{2}+\mathrm{AgF} \longrightarrow \mathrm{AgOCF} \mathrm{CF}_{2} \mathrm{SO}_{2} \mathrm{~F}}{ } \\
\mathrm{CH}_{3} \mathrm{I}+\mathrm{AgOCF} \mathrm{CF}_{2} \mathrm{SO}_{2} \mathrm{~F} \longrightarrow \underset{(\mathrm{IIX})}{\mathrm{CH}_{3} \mathrm{OCF}_{2} \mathrm{CF}_{2} \mathrm{SO}_{2} \mathrm{~F}+\mathrm{AgI}}
\end{gathered}
$$

Attempts were made to incorporate chloropentafluoroacetone into (IIX) using azo(bisisobutyronitrile) (AIBN) as a radical initiator to give both the ether and alcohol products : 


$$
\begin{aligned}
& \stackrel{\stackrel{O}{\|}}{\mathrm{CClF}_{2} \mathrm{CCF}_{3}}+\mathrm{CH}_{3} \mathrm{OCF}_{2} \mathrm{CF}_{2} \mathrm{SO}_{2} \mathrm{~F} \stackrel{\mathrm{AIBN}}{\longrightarrow} \mathrm{H}\left(\mathrm{CClF}_{2}\right) \mathrm{C}\left(\mathrm{CF}_{3}\right) \mathrm{OCH}_{2} \mathrm{OCF}_{2} \mathrm{CF}_{2} \mathrm{SO}_{2} \mathrm{~F} \quad[20] \\
& \mathrm{HO}\left(\mathrm{CClF}_{2}\right) \odot\left(\mathrm{CF}_{3}\right) \mathrm{CH}_{2} \mathrm{OCF}_{2} \mathrm{CF}_{2} \mathrm{SO}_{2} \mathrm{~F}
\end{aligned}
$$

Analysis of the crude product by ${ }^{19} \mathrm{~F}$ NMR revealed presence of only starting materials.

Method 3. The addition/elimination reaction between tetrafluoroethylene (TFE) and the acid fluoride $\mathrm{FC}(\mathrm{O}) \mathrm{CF}_{2} \mathrm{SO}_{2} \mathrm{~F}$ in the presence of cesium fluoride was attempted in order to give the ketone intermediate:

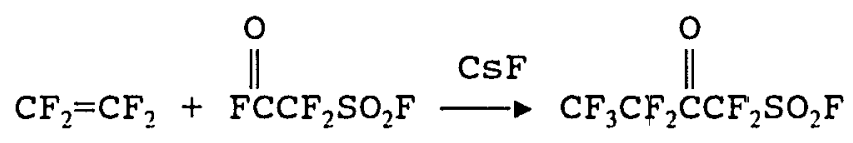

The ${ }^{19} \mathrm{~F}$ NMR spectrum of the crude product revealed mostly unreacted $\mathrm{FC}(\mathrm{O}) \mathrm{CF}_{2} \mathrm{SO}_{2} \mathrm{~F}$. The formation of telomers of TFE was suggested by the presence of complex, unresolved resonances in the regions of -80 to -90 and $-120 \mathrm{ppm}$. Similar results have been observed in cesium fluoride catalyzed telomerization reactions of TFE in the absence of fluorinated ketones $(60)$. The perfluorocarbanion initially formed was demonstrated to have added to TFE followed by loss of fluoride:

$$
\begin{gathered}
\mathrm{CF}_{2}=\mathrm{CF}_{2}+\mathrm{CsF} \longrightarrow \mathrm{CF}_{3}-\mathrm{CF}_{2}^{-} \mathrm{Cs}^{+} \\
\mathrm{CF}_{3}-\mathrm{CF}_{2} \mathrm{Cs}^{+}+\mathrm{CF}_{2}=\mathrm{CF}_{2} \longrightarrow \mathrm{CF}_{3}-\mathrm{CF}_{2}-\mathrm{CF}_{2}-\mathrm{CF}_{2}^{-} \mathrm{Cs}^{+}
\end{gathered}
$$




$$
\mathrm{CF}_{3}-\mathrm{CF}_{2}-\mathrm{CF}_{2}-\mathrm{CF}_{2}^{-} \mathrm{Cs}^{+} \longrightarrow \mathrm{CF}_{3}-\mathrm{CF}_{2}-\mathrm{CF}_{2}=\mathrm{CF}_{2}+\mathrm{CsF}
$$

Further addition - elimination reactions resulted in formation of cis and trans perfluoro-3,4-dimethyl-3-hexene in 58\% yield with higher oligomers also present.

$$
\mathrm{SF}_{5} \text { CONTAINING SALTS }
$$

Similar to $\mathrm{CF}_{3}$ groups, $\mathrm{SF}_{5}$ groups show little tendency to react at the central atom. Both possess a group electronegativity greater than 3.0 and are thus capable of stabilizing nearby anionic sites. The $\mathrm{SF}_{5}$ group also imparts higher dielectric strength to compounds in which it is found (61). These features suggest that a pentafluorosulfur compound may be desirable in such applications as lithium solid polymer electrolyte batteries. Two such compounds, $\mathrm{SF}_{5} \mathrm{CHFSO}_{3} \mathrm{Li}$ (IX) and $\mathrm{SF}_{5} \mathrm{CF}_{2} \mathrm{SO}_{3} \mathrm{Li}(\mathrm{X})$, were prepared and characterized in this work.

Conductivity measurements of solid polymer electrolytes prepared from poly(ethylene oxide) and these salts were performed by Dr. Michael Lerner of Oregon State University. In weight ratios giving eight oxygens in the poly(ethylene oxide) to one lithium of the salts, conductivities of $2 \times 10^{-4}$ and $1 \times 10^{-4} \Omega^{-1} \mathrm{~cm}^{-1}$ for (IX) and (X) were measured at $60^{\circ} \mathrm{C}$. At $100^{\circ} \mathrm{C}$, conductivities of $1 \times 10^{-3}$ and $3 \times 10^{-4} \Omega^{-1} \mathrm{~cm}^{-1}$ were obtained. These represent some of the best conductivities ever determined in these types of solid polymer 
electrolytes, rivaling those of $\mathrm{N}\left(\mathrm{CF}_{3} \mathrm{SO}_{2}\right)_{2} \mathrm{Li}$ and $\mathrm{C}\left(\mathrm{CF}_{3} \mathrm{SO}_{2}\right)_{3} \mathrm{Li}$ which are being aggressively investigated for use in lithium batteries $(16)$.

The lithium sulfonates were prepared from the corresponding sulfonyl fluorides by treatment with lithium hydroxide monohydrate in either water or anhydrous methanol:

$$
\mathrm{SF}_{5} \mathrm{CFXSO}_{2} \mathrm{~F}+2 \mathrm{LiOH} \underset{\mathrm{CH}_{3} \mathrm{OH}}{\stackrel{\mathrm{H}_{2} \mathrm{O} \text { or }}{\longrightarrow}} \begin{aligned}
& \mathrm{SF}_{5} \mathrm{CFXSO}_{3} \mathrm{Li} \\
& \text { (IX) } \mathrm{X}=\mathrm{H}
\end{aligned} \text { (XiF }+\mathrm{H}_{2} \mathrm{O}
$$

Isolation of the products was accomplished by filtration to remove precipitated lithium fluoride followed by removal of the solvent under vacuum. Complexation of the salts by oxygen containing solvents was a difficulty encountered in the work up, and in the case of (IX), the crude product was triturated with hexane in order to remove the last traces of solvent. The salts were powdery white compounds stable to high temperatures with (IX) possibly liberating hydrogen fluoride as etching of the glass melting point capillary tube was observed.

The infrared spectra for these compounds are given in the Experimental section of this chapter and have common features. The $\mathrm{SF}_{5}$ group $\mathrm{S}-\mathrm{F}$ stretching modes were assigned to the strongest bands in both spectra at 858 and $880 \mathrm{~cm}^{-1}$, respectively for $(\mathrm{IX})$ and $(\mathrm{X})$. The $\mathrm{S}-\mathrm{F}$ deformation mode was assigned to a strong band at $597 \mathrm{~cm}^{-1}$ for (X), while for (IX) 
no specific assignment could be made but several medium strength bands fell in the region of 568 to $602 \mathrm{~cm}^{-1}$. Similar values ranging from $832-914$ and $586-598 \mathrm{~cm}^{-1}$ for this group have been reported for $\mathrm{SF}_{5} \mathrm{CHF}-$ and $\mathrm{SF}_{5} \mathrm{CF}_{2}-$ containing sulfonyl fluorides, sulfonate salts and acids $(41,61)$. The asymmetric and symmetric $\mathrm{SO}_{3}$ stretching bands appeared at 1310 and $1088 \mathrm{~cm}^{-1}$ for (X) and at 1296 and $1085 \mathrm{~cm}^{-1}$ for (IX), while the CF motions for both compounds gave strong bands at 1246 and $1228 \mathrm{~cm}^{-1}$ for both. These values agree well with reported values $(41,61)$. The $\mathrm{SO}_{2} \mathrm{~F}$ bands reported to be present in the starting materials were not present in the salts (41).

The NMR spectra of these salts consisted of complex multiplets, however most first-order coupling constants were determined and are presented in TABLE IV along with chemical shifts. The ${ }^{1} \mathrm{H}$ NMR spectrum of (IX) consisted of a doublet of pentets $6.15 \mathrm{ppm}$ from which the ${ }^{2} J_{\mathrm{F}-\mathrm{H}}$ geminal coupling of $44.1 \mathrm{~Hz}$ and ${ }^{3} \mathcal{J}_{\mathrm{F}-\mathrm{H}}$ coupling to the four equatorial $\mathrm{SF}_{5}$ fluorines of $5.6 \mathrm{~Hz}$ were determined. No ${ }^{3} J_{\mathrm{F}-\mathrm{H}}$ coupling to the axial fluorine was observed.

For both compounds, the ${ }^{19} \mathrm{~F}$ NMR showed an $\mathrm{AB}_{4}$ pattern for the $\mathrm{SF}_{5}$ groups. The equatorial fluorine doublets in both spectra possessed extensive fine structure due to second-order effects which could not be directly analyzed. The axial fluorine resonances were observed as nine-line patterns of multiplets, in which for $(x),{ }^{3} J_{F \cdot F}$ coupling to 
the $-\mathrm{CF}_{2}-$ fluorines gave rise to a triplet structure in each branch while for (IX) the fine structure could not be determined. For $(x)$, complete analysis of the spectrum was possible as the $\mathrm{CF}_{2}$ fluorine resonance clearly showed both ${ }^{3} J_{\mathrm{F}-\mathrm{F}}$ couplings to the axial and equatorial $\mathrm{SF}_{5}$ fluorines. The spectrum of (IX) could not be resolved completely, however ${ }^{2} J_{F(A) \text { F(B) }}$ couplings and all chemical shifts were assigned.

For both compounds the centers of the B doublets were assigned for the four equatorial fluorine chemical shifts, while the axial fluorine chemical shifts were determined as the centers (line six) of the nine-line patterns. For (IX), 51.8 and $75.0 \mathrm{ppm}$ were determined for these chemical shifts, while for $(x)$ the corresponding values of 45.0 and $68.4 \mathrm{ppm}$ were found. It should be noted that increased shielding of the $\mathrm{SF}_{5}$ fluorines, upon replacement of hydrogen by fluorine on the adjacent carbon, has occurred. This has been observed in similar systems. For the progression $\mathrm{SF}_{5} \mathrm{CH}_{2} \mathrm{SO}_{2} \mathrm{~F}$, $\mathrm{SF}_{5} \mathrm{CHFSO}_{2} \mathrm{~F}$ and $\mathrm{SF}_{5} \mathrm{CF}_{2} \mathrm{SO}_{2} \mathrm{~F}$, the corresponding values have been reported: $\quad \mathrm{SF}_{(\mathrm{ax})}, 71.4,65.2$ and $60.6 \mathrm{ppm} ; \mathrm{SF}_{4(\mathrm{e}) \mathrm{l})}, 71.4,55.2$ and $47.2 \mathrm{ppm} ;$ and in the calcium salts of $\mathrm{SF}_{5} \mathrm{CH}_{2} \mathrm{SO}_{3}{ }^{\circ}$, $\mathrm{SF}_{5} \mathrm{CHFSO}_{3}{ }^{-}$and $\mathrm{SF}_{5} \mathrm{CF}_{2} \mathrm{SO}_{3}{ }^{\circ}$, the values of: $76.7,77.5,69.5$ and $64.3,55.6,45.0 \mathrm{ppm}$ were reported $(41,61)$.

While the ${ }^{13} \mathrm{C}$ NMR (TABLE V) chemical shift and coupling constants ${ }^{1} J_{C-F}$ and ${ }^{2} J_{C \cdot F((\mathrm{eq})}$ found for (X) $(124.2 \mathrm{ppm}, 334.2$ and $21.4 \mathrm{~Hz}$ ) agree well with those of $127.2 \mathrm{ppm}, 336.3$ and 18.8 
$\mathrm{Hz}$ reported for the acid $\mathrm{SF}_{5} \mathrm{CF}_{2} \mathrm{SO}_{3} \mathrm{H}$ (41) ${ }^{2} J_{\mathrm{C}-\mathrm{F}(\mathrm{ax})}$ coupling could not be determined from the spectral data. For (IX) the ${ }^{2} J_{\text {C-F(cq) }}$ coupling constant was found to be $17.2 \mathrm{~Hz}$, similar to the value of $18.8 \mathrm{~Hz}$ reported for $\mathrm{SF}_{5} \mathrm{CFHSO}_{3} \mathrm{H}$.

TABLE IV

${ }^{1} \mathrm{H}$ AND ${ }^{19} \mathrm{~F}$ NMR DATA FOR SF5CHFSO3Li (IX) AND SF5CF2SO3Li (X)*

\begin{tabular}{|c|c|c|c|}
\hline SF4 (eq) & $\mathrm{CHF}^{\mathrm{a}}$ & $\mathrm{SF}_{4}(\mathrm{eq})$ & $C F 2^{a}$ \\
\hline $\begin{array}{l}75.0(\mathrm{~m}) * * 51.8(\mathrm{~d}, \mathrm{~m}) \\
J F_{(\mathrm{ax})}-F_{(\mathrm{cq})}=153.8\end{array}$ & $\begin{array}{l}F-155.5(\mathrm{~d}, \mathrm{~m}) \\
J F^{2}-H=44.1 \\
H \quad 6.15(\mathrm{~d}, \mathrm{p}) \\
J \mathrm{H}-F_{(\mathrm{eq})}=5.6\end{array}$ & $\begin{array}{l}68.4(\mathrm{~m})^{b} 45.0(\mathrm{~d}, \mathrm{~m}) \\
J F_{(\mathrm{ax})}-\mathrm{F}_{(\mathrm{eq})}=149.6\end{array}$ & $\begin{array}{l}-88.7(\mathrm{~d}, \mathrm{p}) \\
J F^{\mathrm{a}}-F_{(\mathrm{ax})}=4.9 \\
J F^{\mathrm{a}}-F_{(\mathrm{cq})}=14.1\end{array}$ \\
\hline
\end{tabular}

"Chemical shifts in ppm; coupling constants in $\mathrm{Hz}$. "Chemical shift for line six of nine-line pattern.

TABLE V

13C NMR DATA FOR SF5CHFSO3Li (IX) AND SF5CF2SO3Li (X)

\begin{tabular}{lll}
\hline$F(a x) S F 4(e q) C H F^{a} S O 3 L i$ & $F(a x) S F 4(e q) C F 2^{a} S O 3 L i$ \\
\hline$C H F \quad 115.1(d, d, p)$ & $C F 2 \quad 124.2(t, p)$ \\
& $J F^{a}=267.3$ & $J F_{d}=334.2$ \\
& $J H^{a}=178.7$ & $J F_{(e q)}=21.4$ \\
& $J F_{(e q)}=17.2$ &
\end{tabular}

Chemical shifts in ppm; coupling constants in $\mathrm{Hz}$.

The major FAB mass spectrum fragments for $(\mathrm{X})$ are listed in the Experimental Section that follows. A molecular ion was observed as well as several dimer species and fragments that support the structure. 
EXPERIMENTAL

\section{$\mathrm{CHF}\left(\mathrm{OCF} 2 \mathrm{CF} 2 \mathrm{SO}_{2} \mathrm{~F}\right) 2$ (II) and $\mathrm{CF}_{2}(\mathrm{OCF} 2 \mathrm{CF} 2 \mathrm{SO} 2 \mathrm{~F}) 2$ (III)}

A description of the electrochemical fluorination cell used to prepare these compounds can be found in CHAPTER II. The cell electrodes were washed with concentrated nitric acid, rinsed with distilled water and air dried. After assembly, the cell was evacuated, purged with dry nitrogen and the condenser brought to $-15{ }^{\circ} \mathrm{C}$. Anhydrous hydrogen fluoride was then introduced. The cell and electrodes were conditioned at a potential of $5.5 \mathrm{~V}$ until a lsteady base line current of $15 \mathrm{Ma}$ was achieved. Following the addition of $18.8 \mathrm{mmol}(7.76 \mathrm{~g})$ of $\mathrm{CH}_{2}\left(\mathrm{OCF}_{2} \mathrm{CF}_{2} \mathrm{SO}_{2} \mathrm{~F}\right)_{2}$, a $5.5^{\prime} \mathrm{V}$ potential was again applied resulting in an initial current of $60 \mathrm{Ma}$. The potential was removed after passing $5.0 \times 10^{3}$ coulombs of charge or $69 \%$ of the theoretical current required for total fluorination [equation 1]. The hydrogen fluoride was removed by allowing the reflux condenser to/warm to ambient temperature and reducing the pressure in the cell to ca. 400 torr. The oily brown contents of the cell were filtered and then extracted with diethyl ether. Removal of the ether gave $4.43 \mathrm{~g}$ of a clear oil. Analysis by vapor phase chromatography, ${ }^{19} \mathrm{~F}$ and ${ }^{1} \mathrm{H} \mathrm{nmr}$ showed the product to be a mixture of $31 \%(3.1 \mathrm{mmol}, 16 \%$ yield) of the perfluorinated product, $34 \%(3.5 \mathrm{mmol}, 19 \%$ yield) of the monofluorinated product and $34 \%(3.5 \mathrm{mmol}, 20 \%$ recovery $)$ starting material. 
Pure fractions of $\mathrm{CHF}\left(\mathrm{OCF}_{2} \mathrm{CF}_{2} \mathrm{SO}_{2} \mathrm{~F}\right)_{2}$ (II) and $\mathrm{CF}_{2}\left(\mathrm{OCF}_{2} \mathrm{CF}_{2} \mathrm{SO}_{2} \mathrm{~F}\right)_{2}$ (III) were obtained by vapor phase chromatography for nmr, ir and elemental analysis.

The infrared spectrum of $\mathrm{CHF}\left(\mathrm{OCF}_{2} \mathrm{CF}_{2} \mathrm{SO}_{2} \mathrm{~F}\right)_{2}$ had the following bands $\left(\mathrm{cm}^{-1}\right): 1464$ (vs), 1406 (w), 1338 (ms), 1245 (vs), 1210 (vs), 1172 (vs, br), 1143 (vs), 1102 (s, sh. at 1069), 981 (m), 809 (vs, sh at 851), 657 (mw), 643 (w), 608 (s, sh. at 576), $512(\mathrm{w}), 4$ s $(\mathrm{mw}), 464$ (mw).

${ }^{1} \mathrm{H}$ NMR data $\left(\mathrm{CDCl}_{3}\right.$, int. TMS): Chemical shifts and coupling constants are located in TABLE I.

${ }^{19} \mathrm{~F}$ NMR data $\left(\mathrm{CDCl}_{3}\right.$, int. $\left.\mathrm{CFCl}_{3}\right):$ chemical shifts and coupling constants are found in TABLE I; relative integration areas $\mathrm{CFH}(1.0), \mathrm{OCF}_{2}(4.0), \mathrm{CF}_{2} \mathrm{SO}_{2}(4.0)$ and $\mathrm{SO}_{2} \mathrm{~F}$ (2.1)

${ }^{13} \mathrm{C}$ NMR data $\left(\mathrm{CDCl}_{3}\right.$, int. TMS): Chemical shifts and coupling constants are in TABLE II.

The infrared spectrum of $\mathrm{CF}_{2}\left(\mathrm{OCF}_{2} \mathrm{CF}_{2} \mathrm{SO}_{2} \mathrm{~F}\right)_{2}$ had the following bands $\left(\mathrm{cm}^{-1}\right)$ : 1466 (vs, sh. at 1451), 1341 (Vs), 1246 (vs, sh. at 1267), 1213 (vs, sh. at 1195), 1171 (vs), 1138 (vs), 1102 (vs), 1025 (m, sh. at 1001), 991 (m), 888 $(w), 872$ (w), 804 (s, sh. at 839), 709 (vw), 669 (w), 655 (w) .

${ }^{19} \mathrm{~F}$ NMR data $\left(\mathrm{CDCl}_{3}\right.$, int. $\left.\mathrm{CFCl}_{3}\right):$ Chemical shifts and coupling constants are in TABLE $I$; relative integration area $\mathrm{CF}_{2}(1.0), \mathrm{OCF}_{2}(2.0), \mathrm{CF}_{2} \mathrm{SO}_{2}(2.0)$ and $\mathrm{SO}_{2} \mathrm{~F}(1.1)$. ${ }^{13} \mathrm{C}$ NMR data $\left(\mathrm{CDCl}_{3}\right.$, int. TMS ): Chemical shifts and 
coupling constants are in TABLE II.

Mass spectral data (m/e, species): $\mathrm{FAB}^{+} ; 315$ (M$\left.\mathrm{CF}_{2} \mathrm{SO}_{2} \mathrm{~F}\right)^{+}, 198\left(\mathrm{CF}_{2} \mathrm{OCF}_{2} \mathrm{CF}_{2} \mathrm{~S}\right)^{+}, 182\left(\mathrm{C}_{3} \mathrm{~F}_{6} \mathrm{O}_{2}\right)^{+}, 166\left(\mathrm{CF}_{2} \mathrm{OCF}_{2} \mathrm{CF}_{2}\right)^{+}$, $163\left(\mathrm{C}_{3} \mathrm{~F}_{5} \mathrm{O}_{2}\right)^{+}, 147\left(\mathrm{C}_{3} \mathrm{~F}_{5} \mathrm{O}\right)^{+}, 132\left(\mathrm{C}_{2} \mathrm{~F}_{4} \mathrm{O}_{2} \text { or } \mathrm{C}_{2} \mathrm{~F}_{4} \mathrm{~S}\right)^{+}, 116\left(\mathrm{C}_{2} \mathrm{~F}_{4} \mathrm{O}\right)^{+}$, $94\left(\mathrm{C}_{2} \mathrm{~F}_{2} \mathrm{O}_{2} \text { or } \mathrm{C}_{2} \mathrm{~F}_{2} \mathrm{~S}\right)^{+}, 83\left(\mathrm{SO}_{2} \mathrm{~F}\right)^{+} ; \mathrm{EI}^{+} ; 429(\mathrm{M}-\mathrm{F})^{+}$, $314\left(\mathrm{C}_{5} \mathrm{~F}_{10} \mathrm{SO}_{2}\right)^{+}, 265\left(\mathrm{C}_{3} \mathrm{~F}_{7} \mathrm{SO}_{4}\right)^{+}, 249\left(\mathrm{C}_{3} \mathrm{~F}_{7} \mathrm{SO}_{3}\right)^{+}, 213\left(\mathrm{C}_{4} \mathrm{~F}_{7} \mathrm{O}_{2}\right)^{+}$, among other peaks.

Anal. Calcd. for $\mathrm{C}_{5} \mathrm{~F}_{12} \mathrm{~S}_{2} \mathrm{O}_{6}: \mathrm{C}, 13.40 ; \mathrm{F}, 50.9 ; \mathrm{S}$, 14.31. Found: C, 13.39; F, 51.3; S, 14.42\%.

\section{$\mathrm{CH} 2(\mathrm{OCF} 2 \mathrm{CF} 2 \mathrm{SO} 3 \mathrm{Na}) 2$ (IV)}

Into a $100 \mathrm{ml}$ Pyrex round-bottom flask equipped with a reflux condenser, a Teflon stirring bar and a dropping funnel charged with $19.7 \mathrm{mmol}(8.10 \mathrm{~g})$ of $\mathrm{CH}_{2}\left(\mathrm{OCF}_{2} \mathrm{CF}_{2} \mathrm{SO}_{2} \mathrm{~F}\right)_{2}$ were added $103 \mathrm{mmol}(4.10 \mathrm{~g})$ of $\mathrm{NaOH}$ and $50 \mathrm{ml} \mathrm{H}_{2} \mathrm{O}$. The sulfonyl fluoride was added over a 25 minute period with stirring. The reaction flask was heated to reflux with stirring for 2 days. After cooling, the contents were filtered to give $10.20 \mathrm{~g}$ of crude product which was purified by continuous extraction with diethyl ether giving $17.9 \mathrm{mmol}$ $(8.07 \mathrm{~g})$ of $\mathrm{Na}_{2}\left[\mathrm{CH}_{2}\left(\mathrm{OCF}_{2} \mathrm{CF}_{2} \mathrm{SO}_{3}\right)_{2}\right](90.8 \%$ yield) which melted at $267-270^{\circ} \mathrm{C}$.

The infrared spectrum of $\mathrm{CH}_{2}\left(\mathrm{OCF}_{2} \mathrm{CF}_{2} \mathrm{SO}_{3} \mathrm{Na}\right)_{2}$ had the following bands $\left(\mathrm{cm}^{-1}\right): 1328$ (wm), 1293 (vs), 1279 (Vs), 1250 (vs, sh. at 1202), 1145 (vs), 1117 (vs), 1068 (s), $1040(\mathrm{~m}), 1019(\mathrm{~m}), 984$ (ms), $963(\mathrm{~m}), 941$ (m), 899 (Wm, 
br), 829 (w), 766 (w), 660 (s), 625 (ms), 590 (wm), 541 (m). ${ }^{1} \mathrm{H}$ NMR data $\left(\mathrm{CDCl}_{3}\right.$, int. TMS): Chemical shifts and coupling constants in are TABLE I.

${ }^{19} \mathrm{~F}$ NMR data $\left(\mathrm{CDCl}_{3}\right.$, int. $\left.\mathrm{CFCl}_{3}\right) ;$ Chemical shifts and coupling constants are in TABLE I; relative integration areas $\mathrm{OCF}_{2}(1.0), \mathrm{CF}_{2} \mathrm{SO}_{3}(1.0)$.

${ }^{13} \mathrm{C}$ NMR data $\left(\mathrm{CDCl}_{3}\right.$, int. TMS): Chemical shifts and coupling constants are in TABLE II.

Anal. Calcd. for $\mathrm{Na}_{2} \mathrm{C}_{5} \mathrm{~F}_{8} \mathrm{~S}_{2} \mathrm{O}_{8}: \mathrm{C}, 13.28 ; \mathrm{H}, 0.45 ; \mathrm{S}$, 14.16; F, 33.6. Found: C, 13.48; H, 0.74; S, 12.72; F, $32.8 \%$

$\mathrm{CF}_{2}\left(\mathrm{OCF} 2 \mathrm{CF} 2 \mathrm{SO}_{3}\right) 2 \mathrm{Ca}$ (V)

Into a three-neck $100 \mathrm{ml}$ Pyrex round-bottom flask equipped with a Teflon stirring bar, a dropping funnel containing $10.4 \mathrm{mmol}(4.68 \mathrm{~g})$ of $\mathrm{CF}_{2}\left(\mathrm{OCF}_{2} \mathrm{CF}_{2} \mathrm{SO}_{2} \mathrm{~F}\right)_{2}$ and attached to a reflux condenser connected to a trap cooled to $-78^{\circ} \mathrm{C}, 42.1 \mathrm{mmol}(2.36 \mathrm{~g})$ of $\mathrm{CaO}$ and $50 \mathrm{ml} \mathrm{H}_{2} \mathrm{O}$ were added. The sulfonyl fluoride was added ovef a 25 minute period with stirring. The reaction flask was heated at $95-100^{\circ} \mathrm{C}$ with stirring for 5 days. After cooling, the contents were filtered and the filtrate was heated to dryness and then dried in vacuo to give $9.57 \mathrm{mmol}(4.61 \mathrm{~g})$ of $\mathrm{Ca}\left[\mathrm{CF}_{2}\left(\mathrm{OCF}_{2} \mathrm{CF}_{2} \mathrm{SO}_{3}\right)_{2}\right] ; 92 \%$ yield. The product was stable to $>360^{\circ} \mathrm{C}$. 
The infrared spectrum of $\mathrm{CF}_{2}\left(\mathrm{OCF}_{2} \mathrm{CF}_{2} \mathrm{SO}_{3}\right)_{2} \mathrm{Ca}$ had the following bands $\left(\mathrm{cm}^{-1}\right): 1349$ (m, sh. at 1333), 1267 (vs, sh. at 1247), 1181 (s), 1149 (ms), 1097 (s), 1054 (wm), 988 (m, sh. at 999), 838(w), $703(\mathrm{vw}), 677(\mathrm{wm}), 662(\mathrm{w}), 636(\mathrm{~m})$, $522(w)$.

${ }^{19} \mathrm{~F}$ NMR data $\left(\mathrm{CDCl}_{3}\right.$, int. $\left.\mathrm{CFCl}_{3}\right):$ Chemical shifts and coupling constants are in TABLE I; relative integration areas $\mathrm{OCF}_{2} \mathrm{O}(1.0), \mathrm{OCF}_{2}(2.1), \mathrm{CF}_{2} \mathrm{SO}_{3}(2.2)$.

${ }^{13} \mathrm{C}$ NMR data $\left(\mathrm{CDCl}_{3}\right.$, int. TMS): Chemical shifts and coupling constants are in TABLE II.

Mass spectral data (m/e, species): FAB $; 705\left[\mathrm{M}_{2} \mathrm{H}_{2}-\right.$ $\left.\mathrm{C}_{4} \mathrm{~F}_{7} \mathrm{SO}_{3}\right]^{+}, 613\left(\mathrm{M}_{2} \mathrm{H}-\mathrm{CaSO}_{3} \mathrm{C}_{2} \mathrm{~F}_{4} \mathrm{OCF}_{2} \mathrm{OCF}_{2}\right)^{+}, 587\left(\mathrm{M}_{2} \mathrm{H}-\right.$ $\left.\mathrm{CaSO}_{3} \mathrm{C}_{2} \mathrm{~F}_{4} \mathrm{OCF}_{2} \mathrm{OCF}_{4}\right)^{+}, 401\left(\mathrm{MH}-\mathrm{CF}_{2} \mathrm{O}_{2}\right)^{+}, 347\left(\mathrm{M}-\mathrm{OC}_{2} \mathrm{~F}_{5}\right)^{+}$, $314\left(\mathrm{C}_{5} \mathrm{~F}_{10} \mathrm{O}_{2} \mathrm{SO}\right)^{+}, 295\left(\mathrm{C}_{5} \mathrm{~F}_{9} \mathrm{O}_{2} \mathrm{SO}\right)^{+}, 233\left(\mathrm{M}-\mathrm{O}_{5} \mathrm{C}_{3} \mathrm{~F}_{7}\right)^{+}, 132\left(\mathrm{C}_{2} \mathrm{~F}_{4} \mathrm{O}_{2}\right)^{+}$, $114\left(\mathrm{CF}_{2} \mathrm{SO}_{2}\right)^{+}, 98\left(\mathrm{CF}_{2} \mathrm{SO}^{+}, 40(\mathrm{Ca})^{+}, \mathrm{FAB}^{-} ; 925(2 \mathrm{MH}-\mathrm{Ca})^{-}\right.$, $845\left(2 \mathrm{MH}-\mathrm{Ca}-\mathrm{SO}_{3}\right)^{\circ}, 825\left(2 \mathrm{M}-\mathrm{Ca}-\mathrm{SO}_{3} \mathrm{~F}\right)^{\circ}, 659\left(2 \mathrm{M}-\mathrm{Ca}-\mathrm{CF}_{2} \mathrm{OC}_{2} \mathrm{~F}_{4} \mathrm{SO}_{3}-\mathrm{F}\right)^{-}$, $573\left[2 \mathrm{MH}-2\left(\mathrm{OC}_{2} \mathrm{~F}_{4} \mathrm{SO}_{3}\right)\right]^{\circ}, 562\left(\mathrm{M}+\mathrm{SO}_{3}\right)^{\circ}, 501[\mathrm{MF}]^{\circ}, 483(\mathrm{MH})^{\circ}, 443$ $(\mathrm{MH}-\mathrm{Ca})^{-}, 423(\mathrm{M}-\mathrm{Ca}-\mathrm{F})^{\circ}, 362\left[\mathrm{OCF}_{2}\left(\mathrm{OC}_{2} \mathrm{~F}_{4} \mathrm{~S}\right)_{2}\right]^{\circ}, 316\left(\mathrm{M}-\mathrm{CF}_{2} \mathrm{OC}_{2} \mathrm{~F}_{4}\right)^{\circ}$, $180\left(\mathrm{OC}_{2} \mathrm{~F}_{4} \mathrm{SO}_{2}\right)^{\circ}, 177\left(\mathrm{OC}_{2} \mathrm{~F}_{3} \mathrm{SO}_{3}\right)^{\circ}, 161\left(\mathrm{OC}_{2} \mathrm{~F}_{3} \mathrm{SO}_{2}\right)^{-}$.

Anal. Calcd. for $\mathrm{CaC}_{5} \mathrm{~F}_{10} \mathrm{~S}_{2} \mathrm{O}_{8}: \mathrm{Ca}, 8.31 ; \mathrm{C}, 12.45 ; \mathrm{F}$, $39.40 ; \mathrm{S}, 13.30$. Found: $\mathrm{Ca}, 8.90 ; \mathrm{S}, 12.70 ; \mathrm{F}, 37.5 \%$.

\section{CF2 (OCF2CF2SO3H) 2 (VI)}

An 0.23 mmol quantity $(0.1119 \mathrm{~g})$ of $\mathrm{CF}_{2}\left(\mathrm{OCF}_{2} \mathrm{CF}_{2} \mathrm{SO}_{2} \mathrm{~F}\right)_{2} \mathrm{Ca}$ dissolved in $5 \mathrm{ml}$ of distilled water was passed through an $8.0 \mathrm{~cm}$ long $\times 1.0 \mathrm{~cm}$ diameter bed of Dowex $50 \mathrm{~W}-\mathrm{X} 12$ cation 
exchange resin in the protonated form (14 meq exchange capacity). Elution with distilled water gave a $5 \mathrm{ml}$ fraction that was highly acidic. Removal of the water by heating in an oven at $110^{\circ} \mathrm{C}$ followed by desiccation over $\mathrm{P}_{4} \mathrm{O}_{10}$ resulted in $0.0938 \mathrm{~g}$ of clear viscous highly acidic product.

The infrared spectrum of $\mathrm{CF}_{2}\left(\mathrm{OCF}_{2} \mathrm{CF}_{2} \mathrm{SO}_{3} \mathrm{H}\right)_{2}$ as a capillary film on Agcl had the following bands $\left(\mathrm{cm}^{-1}\right): 3458$ (s, broad) ; 1750 (m, broad) ; 1335 (s); 1250 (vs); 1166 (vs, shldr at 1181); 1103 (vs); 1060 (s); 1000 (m); 984 (m); 971 (s); 882 (w); 834 (w); 638 (s, shldr at 658); 538 (m). ${ }^{\text {'H }} \mathrm{NMR}$ data $\left(\mathrm{CDCl}_{3}\right.$, int. TMS): Chemical shifts and coupling constants are in TABLE I.

${ }^{19} \mathrm{~F}$ NMR data $\left(\mathrm{CDCl}_{3}\right.$, int. $\left.\mathrm{CFCl}_{3}\right):$ Chemical shifts and coupling constants are in TABLE I; relative integration areas $\mathrm{DCF}_{2} \mathrm{O}(1.0), \mathrm{OCF}_{2}(2.1), \mathrm{CF}_{2} \mathrm{~S}(2.1)$.

${ }^{13} \mathrm{C}$ NMR data $\left(\mathrm{CDCl}_{3}\right.$, int. TMS): Chemical shifts and coupling constants are in TABLE II.

\section{$\mathrm{FC}(\mathrm{CF} 3) 2 \mathrm{OCH} 2 \mathrm{CH} 2 \mathrm{OCF} 2 \mathrm{CF} 2 \mathrm{SO} 2 \mathrm{~F}$ (VII)}

Into a $130 \mathrm{ml}$ Pyrex-glass Carius tube equipped with a Kontes Teflon stopcock and containing a Teflon stirring bar and $15.1 \mathrm{mmol}(1.92 \mathrm{~g})$ of dry AgF was added $10 \mathrm{ml}$ of distilled acetonitrile. The carius tube was wrapped in aluminum foil to exclude light and $17.5 \mathrm{mmol}(2.90 \mathrm{~g})$ of $\left(\mathrm{CF}_{3}\right)_{2} \mathrm{CO}$ was added. The mixture was stirred for $10 \mathrm{~h}$ at 
ambient temperature and $5.86 \mathrm{mmol}(1.80 \mathrm{~g})$ of $\mathrm{BrCH}_{2} \mathrm{CH}_{2} \mathrm{OCF}_{2} \mathrm{CF}_{2} \mathrm{OCF}_{2} \mathrm{CF}_{2} \mathrm{SO}_{2} \mathrm{~F}$ was then added. The carius tube was placed on a shaking apparatus at ambient temperature for 24 $\mathrm{h}$ and then the contents were heated to $40^{\circ} \mathrm{C}$ with stirring for an additional $10 \mathrm{~h}$. The light brown reaction mixture was filtered, washed with water then dried over magnesium sulfate. Distillation gave $2.86 \mathrm{mmol}(1.18 \mathrm{~g})$ of a clear oily product in $49 \%$ yield: b.p. $71-72^{\circ} \mathrm{C} / 25$ torr.

The infrared spectrum of $\mathrm{FC}\left(\mathrm{CF}_{3}\right)_{2} \mathrm{OCH}_{2} \mathrm{CH}_{2} \mathrm{OCF}_{2} \mathrm{CF}_{2} \mathrm{SO}_{2} \mathrm{~F}$ had the following bands $\left(\mathrm{cm}^{-1}\right): 2973$ (w), 1547 (vs), 1392 (m), 1331 (vs), 1299 (s), 1233 (vs), 1184 (vs), 1146 (vs), 1123 (vs), 1049 (s), 1033 (s), 992 (vs), 857 (w), 812 (s), 790 (s), 732 (s), 655 (m), 610 (s), 546 (w), 488 (w).

'H NMR data $\left(\mathrm{CCl}_{4}\right.$ ext. TMS): chemical shifts are in TABLE III; no relative integration areas found for the unresolved $\mathrm{A}_{2} \mathrm{~B}_{2}$ pattern.

${ }^{19} \mathrm{~F}$ NMR data $\left(\mathrm{CCl}_{4}\right.$, ext $\left.\mathrm{CFCl}_{3}\right)$ : chemical shifts and coupling constants are in TABLE III; relative integration area FC (1.0), $\left(\mathrm{CF}_{3}\right)_{2}(6.1), \mathrm{OCF}_{2}(2.1), \mathrm{CF}_{2} \mathrm{~S}(2.1), \mathrm{SO}_{2} \mathrm{~F}$ (1.1)

Mass spectral data (m/e, species): $\mathrm{EI}^{+} ; 329\left(\mathrm{M}-\mathrm{SO}_{2} \mathrm{~F}\right)^{+}$, $227\left(\mathrm{CH}_{2} \mathrm{CH}_{2} \mathrm{OCF}_{2} \mathrm{CF}_{2} \mathrm{SO}_{2} \mathrm{~F}\right)^{+}, 213\left(\mathrm{FC}\left(\mathrm{CF}_{3}\right)_{2} \mathrm{OCH}_{2} \mathrm{CH}_{2}\right)^{+}, 199$ $\left(\mathrm{FC}\left(\mathrm{CF}_{3}\right)_{2} \mathrm{OCH}_{2}\right)^{+}, 169\left(\mathrm{FC}(\mathrm{CF} 3)_{2}{ }^{+}, 100\left(\mathrm{CF}_{2} \mathrm{CF}_{2}\right)^{+}, 97\left(\mathrm{C}_{2} \mathrm{~F}_{3} \mathrm{O}\right)^{+}, 69\right.$ $\left(\mathrm{CF}_{3}\right)^{+}, 67\left(\mathrm{CF}_{2} \mathrm{OH}\right)^{+}, 47(\mathrm{COF})^{+}$.

Anal. Calcd. for $\mathrm{C}_{7} \mathrm{H}_{4} \mathrm{~F}_{12} \mathrm{SO}_{4}: \mathrm{C}, 20.40 ; \mathrm{H}, 0.98 ; \mathrm{F}, 55.3$; S, 7.78. Found: C, $20.57 ; \mathrm{H}, 0.95 ; \mathrm{F}, 55.0 ; \mathrm{S}, 7.92 \%$. 


\section{CH3OCF2CF2SO2F (IIX)}

To a $75 \mathrm{ml}$ pyrex glass reaction vessel containing a Teflon coated stirring bar and fitted with a high vacuum stopcock was placed $91.9 \mathrm{mmol}(11.67 \mathrm{~g}) \mathrm{mmol}$ of dry AgF and $30 \mathrm{ml}$ of diglyme. To this was added via vacuum $99.5 \mathrm{mmol}$ $(17.91 \mathrm{~g})$ of $\mathrm{CF}_{2} \mathrm{CF}_{2} \mathrm{OSO}_{2}$. The reaction vessel was placed in a $35^{\circ} \mathrm{C}$ oil bath and the contents stirred for one day. $\mathrm{CH}_{3} \mathrm{I}$ $(84.5 \mathrm{mmol}, 12.00 \mathrm{~g})$ was added and the mixture stirred in a $45^{\circ} \mathrm{C}$ oil bath for three days. The contents of the vessel were removed via vacuum and washed eight times with $10 \mathrm{ml}$ of water, dried over $\mathrm{MgSO}_{4}$ to give $61.8 \mathrm{mmol}(13.22 \mathrm{~g}$ ) of $\mathrm{CH}_{3} \mathrm{OCF}_{2} \mathrm{CF}_{2} \mathrm{SO}_{2} \mathrm{~F}$ obtained by distillation (b.p. 87-88 $\mathrm{C} / 1 \mathrm{~atm}$; $73 \%$ yield).

The infrared spectrum of $\mathrm{CH}_{3} \mathrm{OCF}_{2} \mathrm{CF}_{2} \mathrm{SO}_{2} \mathrm{~F}$ had the following bands $\left(\mathrm{cm}^{-1}\right): 3030(\mathrm{vw}) ; 2980(\mathrm{w}) ; 2875(\mathrm{w}) ; 1460(\mathrm{vs})$; 1342 (vs)； 1242 (vs)； 1199(vs)；1178(vs)；1136(vs)；1110(vs); $1047(\mathrm{~m}) ; 1005(\mathrm{vs}) ; 942(\mathrm{~m}) ; 804(\mathrm{vs}) ; 770(\mathrm{vs}) ; 655(\mathrm{~s}) ;$ 611 (vs).

${ }^{1} \mathrm{H}$ NMR data $\left(\mathrm{CDCl}_{3}\right.$, int. TMS ): chemical shifts and coupling constants are in TABLE IV.

${ }^{19} \mathrm{~F}$ NMR data $\left(\mathrm{CDCl}_{3}\right.$, int. $\left.\mathrm{CFCl}_{3}\right)$ : chemical shifts and coupling constants are in TABLE IV; relative integration area $\mathrm{OCF}_{2}(2.1), \mathrm{CF}_{2}(2.0), \mathrm{SO}_{2} \mathrm{~F}(1.0)$. 
TABLE VI

${ }^{1} \mathrm{H}$ AND ${ }^{19} \mathrm{~F}$ NMR DATA FOR CH3OCF2CF2SO2F (IIX)

\begin{tabular}{|c|c|c|c|}
\hline $\mathrm{CH} 3^{\mathrm{a}}$ & $O C F 2^{b}$ & $C F 2^{c}$ & $\mathrm{SO} 2 \mathrm{~F}^{\mathrm{d}}$ \\
\hline 4.18 (s) & $\begin{array}{c}+88.3(d, t) \\
J F^{b}-F^{c}=4.8\end{array}$ & $\begin{array}{l}-92.6 \quad(d, t) \\
J F^{c}-F^{d}=4.8\end{array}$ & $\begin{array}{l}44.0(t, t) \\
J F^{d}-F^{b}=5.1\end{array}$ \\
\hline
\end{tabular}

'Chemical shifts in ppm; coupling constants in $\mathrm{Hz}$.

TABLE VII

${ }^{13} \mathrm{C}$ NMR DATA FOR CH3OCF2CF2SO2F (IIX)

\begin{tabular}{lll}
\hline $\mathrm{CH}^{\mathrm{a}}$ & \multicolumn{1}{c}{$\mathrm{OCF}^{\mathrm{b}}$} & \multicolumn{1}{c}{$C F 2^{\mathrm{c} S O 2 F^{\mathrm{d}}}$} \\
\hline $52.8(q, t)$ & $116.9(t, t, d)$ & $114.3(t, t, d)$ \\
$J H^{\mathrm{a}}=149.7$ & $J F^{\mathrm{b}}=274.4$ & $J F^{\mathrm{c}}=114.3$ \\
$J F^{\mathrm{b}}=6.1$ & $J F^{\mathrm{c}}=27.9$ & $J F^{\mathrm{b}}=34.7$ \\
& $J F^{\mathrm{d}}=3.7$ & $J F^{\mathrm{d}}=41.9$ \\
\hline
\end{tabular}

"Chemical shifts in ppm; coupling constants in $\mathrm{Hz}$.

\section{$\mathrm{CH}_{30 \mathrm{OCF}} 2 \mathrm{CF} 2 \mathrm{SO}_{2} \mathrm{~F}$ with $\mathrm{ClCF} 2(\mathrm{O}) \mathrm{CF}_{3}$}

To a dried $100 \mathrm{ml}$ Carius tube was added $23.5 \mathrm{mmol}$ (5.03 g) of $\mathrm{CH}_{3} \mathrm{OCF}_{2} \mathrm{CF}_{2} \mathrm{SO}_{2} \mathrm{~F}$ and $1.2 \mathrm{mmol}(0.19 \mathrm{~g})$ of azo(bis-isobutyronitrile). After the addition of $18.4 \mathrm{mmol}(3.35 \mathrm{~g}$ ) of $\mathrm{CF}_{3} \mathrm{C}(0) \mathrm{CF}_{2} \mathrm{Cl}$ via/vacuum, the carius tube was placed in a $40^{\circ}$ $C$ oil bath, heated to $80^{\circ} \mathrm{C}$ over a two hour period and maintained at this temperature for 25 hours.

Analysis of the ${ }^{19} \mathrm{~F}$ NMR spectrum of the crude product revealed presence of starting material only. 


\section{CF2CF2 with $\mathrm{FC}(\mathrm{O}) \mathrm{CF} 2 \mathrm{SO} 2 \mathrm{~F}$}

To a $50 \mathrm{~mL}$ Carius tube containing a Tefion coated stirring bar was added $61.6 \mathrm{mmol}(93.5 \mathrm{~g})$ of dry CsF, $20 \mathrm{~mL}$ of diglyme and $60.2 \mathrm{mmol}(10.8 \mathrm{~g})$ of $\mathrm{CF}_{2} \mathrm{CF}_{2} \mathrm{OSO}_{2}$. The slurry was stirred at room temperature for $1 \mathrm{~h}$ at which time the CSF was dissolved. Tetrafluoroethylene was introduced from an external storage vessel fitted with a pressure gauge. The mixture was stirred at $100^{\circ} \mathrm{C}$ for 5 days while maintaining a pressure of 30 psig of TFE. After this time the pressure was released and the contents allowed to cool. The ${ }^{19} \mathrm{~F}$ NMR spectrum of the crude product revealed mostly unreacted $\mathrm{FC}(\mathrm{O}) \mathrm{CF}_{2} \mathrm{SO}_{2} \mathrm{~F}$.

The filtered solution was acidified, the lower layer separated, washed with water and dried over $\mathrm{MgSO}_{4}$ Distillation resulted in $2.33 \mathrm{~g}$ of recovered sultone, $1.11 \mathrm{~g}$ of an oily product (b.p. $100^{\circ} \mathrm{C} / 10$ torr) possibly identified as telomers of TFE as suggested by complex, unresolved ${ }^{19} \mathrm{~F}$ NMR resonances in the regions of -80 to -90 and $-120 \mathrm{ppm}$ and $4.97 \mathrm{~g}$ of tarry pot residue.

\section{SF5CHFSO3Li (IX)}

To a $100 \mathrm{ml}$ three-neck flask containing a Teflon stirring bar and fitted with an addition funnel, a reflux condenser and a thermometer was added $40 \mathrm{ml}$ of anhydrous methanol and $43.9 \mathrm{mmol}(1.84 \mathrm{~g})$ of $\mathrm{LiOH} \cdot \mathrm{H}_{2} \mathrm{O}$. The flask was cooled in an ice bath and $18.9 \mathrm{mmol}(4.58 \mathrm{~g})$ of $\mathrm{SF}_{5} \mathrm{CHFSO}_{2} \mathrm{~F}$ 
was added with stirring at such a rate that the temperature was kept below $20^{\circ} \mathrm{C}$. The turbid mixture was stirred at room temperature for $16 \mathrm{hr}$ then heated to reflux for $4 \mathrm{hr}$. The mixture was cooled in an ice bath and filter to remove the flocculent precipitate. The filtrate was evaporated via vacuum to give $4.48 \mathrm{~g}$ of crude product which was dissolved in tetrahydrofuran and filtered. Removal of the tetrahydrofuran via vacuum resulted a paste which was triturated with hexane and dried via vacuum for 2 days to give $16.7 \mathrm{mmol}(4.12 \mathrm{~g})$ of $\mathrm{SF}_{5} \mathrm{CHFSO}_{3} \mathrm{Li}$ in $89 \%$ yield. M.p. $295^{\circ} \mathrm{C}$ sintering, $315^{\circ} \mathrm{C}$ darkening and m.p. tube etched. The infrared spectrum of $\mathrm{SF}_{5} \mathrm{CHFSO}_{3} \mathrm{Li}$ had the following bands $\left(\mathrm{cm}^{-1}\right): 3001(\mathrm{Vw}) ; 1321(\mathrm{~s}) ; 1296(\mathrm{vs}) ; 1228(\mathrm{vs})$; $1135(\mathrm{~m}) ; 1083(\mathrm{~m}) ; 917(\mathrm{sh}) ; 881(\mathrm{sh}) ; 857(\mathrm{vs}) ; 828(\mathrm{~m}) ; 732(\mathrm{~m}) ;$ $678(\mathrm{w}) ; 646(\mathrm{~m}) ; 603(\mathrm{~m}) ; 567(\mathrm{w})$.

${ }^{1} \mathrm{H}$ NMR data $\left(\mathrm{CD}_{3} \mathrm{CN}\right.$, ext. TMS $)$ chemical shifts and coupling constants are in TABLE VI.

${ }^{19} \mathrm{~F}$ NMR data $\left(\mathrm{CD}_{3} \mathrm{CN}\right.$, ext. $\left.\mathrm{CFCl}_{3}\right):$ chemical shifts and coupling constants are in TABLE VI; relative integration area $\mathrm{FS}_{(\mathrm{ax})}(1.0), \mathrm{SF}_{4(\mathrm{eq})}(4.0), \mathrm{CHF}(1.1)$.

${ }^{13} \mathrm{C}$ NMR spectral data $\left(\mathrm{CD}_{3} \mathrm{CN}\right.$, int. TMS $):$ chemical shifts and coupling constants are in TABLE VII.

Anal. Calcd. $\mathrm{CHF}_{6} \mathrm{SO}_{3} \mathrm{Li}: \mathrm{C}, 4.48 ; \mathrm{H}, 0.41 ; \mathrm{F}, 46.3 ; \mathrm{S}$, 26.06. Found: C, 5.03; H, 0.53; F, 45.5; S, 26.74\%. Conductivity measurements of dried product in poly(ethylene oxide) for stoichiometric ratio $\left(\mathrm{CH}_{2} \mathrm{CH}_{2} \mathrm{O}\right)_{x} \mathrm{Li}$ 
$\mathrm{x}=8: 2 \times 10^{-4} \Omega^{-1} \mathrm{Cm}^{-1}\left(60^{\circ} \mathrm{C}\right) ; 1 \times 10^{-3} \Omega^{-1} \mathrm{~cm}^{-1}\left(100^{\circ} \mathrm{C}\right)$

SF5CF2SO3Li (X)

To a $100 \mathrm{ml}$ round bottom flask containing a Tefion coated stirring bar and fitted with a reflux condenser and an addition funnel was added $40 \mathrm{ml}$ of water and $26.9 \mathrm{mmol}$ $(1.13 \mathrm{~g})$ of $\mathrm{LiOH} \cdot \mathrm{H}_{2} \mathrm{O}$. Over a $20 \mathrm{~min}$ period $13.4 \mathrm{mmol}$ (3.49 g) of $\mathrm{SF}_{5} \mathrm{CF}_{2} \mathrm{SO}_{2} \mathrm{~F}$ was added with stirring. The mixture was heated to reflux in a $70^{\circ} \mathrm{C}$ oil bath for two days at which time the lower phase was no longer present. The cloudy solution was then heated to reflux at $100^{\circ} \mathrm{C}$ for $4 \mathrm{hr}$ and allowed to cool. Filtration gave a clear solution from which the water was removed by rotary evaporation followed by dynamic vacuum for 10 days. This resulted in $6.5 \mathrm{mmol}$ $(1.72 \mathrm{~g})$ of white powdery $\mathrm{SF}_{5} \mathrm{CF}_{2} \mathrm{SO}_{3} \mathrm{Li}$ in $49 \%$ yield, m.p. 270 ${ }^{\circ} \mathrm{C}$ sintering, stable to $>350^{\circ} \mathrm{C}$.

The infrared spectrum of $\mathrm{SF}_{5} \mathrm{CF}_{2} \mathrm{SO}_{3} \mathrm{Li}$ had the following bands $\left(\mathrm{cm}^{-1}\right)$ : $1310(\mathrm{vs}) ; 1246(\mathrm{vs}) ; 1194(\mathrm{~s}) ; 1140(\mathrm{~s})$; $1088(\mathrm{~s}) ; 967(\mathrm{w}) ; 905(\mathrm{sh}) ; 880(\mathrm{vs}) ; 840(\mathrm{vs}) ; \quad 676(\mathrm{~m})$; $628(\mathrm{w}) ; 597(\mathrm{~m}) ; 574(\mathrm{w}) ; 542(\mathrm{w})$.

${ }^{19} \mathrm{~F}$ NMR data $\left(\mathrm{CD}_{3} \mathrm{CN}\right.$, ext. $\left.\mathrm{CFCl}_{3}\right):$ chemical shifts and coupling constants are in TABLE VI.; relative integration area $\mathrm{FS}_{(\mathrm{ax})}(1.0), \mathrm{SF}_{4(\mathrm{eq})}(4.1), \mathrm{CF}_{2}(1.9)$.

${ }^{13} \mathrm{C}$ NMR data $\left(\mathrm{CD}_{3} \mathrm{CN}\right.$, int. TMS $)$ : chemical shifts and coupling constants are in TABLE VII.

Mass spectral data (m/e, species): $\mathrm{FAB}^{\prime} ; 785$ $\left(2 \mathrm{M} \cdot \mathrm{SF}_{5} \mathrm{CF}_{2} \mathrm{SO}_{3}\right), 547(2 \mathrm{M} \cdot \mathrm{F}), 521\left(\mathrm{SF}_{5} \mathrm{CF}_{2} \mathrm{SO}_{3}\right)_{2} \mathrm{Li}, 283(\mathrm{M} \cdot \mathrm{F}), 264$ 
(M), $257\left(\mathrm{SF}_{5} \mathrm{CF}_{2} \mathrm{SO}_{3}\right), 149\left(\mathrm{CF}_{3} \mathrm{SO}_{3}\right), 130\left(\mathrm{CF}_{2} \mathrm{SO}_{3}\right), 127\left(\mathrm{SF}_{5}\right), 80$ $\left(\mathrm{SO}_{3}\right)$.

Anal. Calcd. for $\mathrm{CF}_{7} \mathrm{SO}_{3} \mathrm{Li} \cdot \mathrm{H}_{2} \mathrm{O}: \mathrm{C}, 4.26 ; \mathrm{H}, 0.71 ; \mathrm{F}$, 47.1; S, 22.73. Found: C, 4.31; H, 0.55; F, 46.3; S, $23.6 \%$

Conductivity measurements of dried product in poly(ethylene oxide) for stoichiometric ratio $\left(\mathrm{CH}_{2} \mathrm{CH}_{2} \mathrm{O}\right)_{x} \mathrm{Li}$ $\mathrm{x}=8: 1 \times 10^{-4} \Omega^{-1} \mathrm{~cm}^{-1}\left(60^{\circ} \mathrm{C}\right) ; 3 \times 10^{-4} \Omega^{-1} \mathrm{~cm}^{-1}\left(100^{\circ} \mathrm{C}\right)$. 
CHAPTER V

REACTIVE INTERMEDIATES AND POLYMERIC COMPOUNDS

As discussed in CHAPTERS I and II, a limited variety of polymeric fluoroalkyl sulfonic acids exist. While these polymers are of great technological and commercial importance, they find limited use in coating applications. The polymers are formed in bulk or as emulsions using gaseous intermediates requiring free-radical polymerization conditions of high temperature and pressure. Applying these polymers as coatings is difficult, since the fluoroalkyl backbone which gives these polymers their outstanding properties also renders them practically insoluble in most common solvents.

For optimum performance in electrochemical devices, good mechanical and electrical contact between the electrodes and the polymer electrolyte is essential. In fuel cells utilizing Nafion as a solid polymeric electrolyte, the polymer is usually hot-pressed to the electrodes in order to achieve good contact. The bulk polymer may also be dissolved to a limited extent in DMso or sulfolane at elevated temperature and pressure. The resulting solutions have been used to apply thin polymer coatings over platinized carbon on fuel cell electrodes (62). 
In order to prepare polymeric fluoroalkyl sulfonyl fluorides, sulfonate salts and sulfonic acids for use as coatings, intermediate compounds possessing both a fluoroalkyl sulfonyl fluoride group and a reactive site capable of in situ polymerization were sought. Compounds investigated included epoxides, halohydrins, diols, acrylic esters and olefins.

\section{Ring-opening Reactions of Epoxides}

only one fluorocarbon system containing both a sulfonyl fluoride and an alcohol group has been reported, $\mathrm{HOCH}_{2} \mathrm{CH}_{2} \mathrm{CF}_{2} \mathrm{CF}_{2} \mathrm{OCF}_{2} \mathrm{CF}_{2} \mathrm{SO}_{2} \mathrm{~F}$ (42). The syntheses of this alcohol require inherently dangerous high temperature and high pressure reactions involving tetrafluoroethylene. By use of ring-opening reactions of the epoxide $\mathrm{OCH}_{2} \mathrm{CHCH}_{2} \mathrm{OCF}_{2} \mathrm{CF}_{2} \mathrm{SO}_{2} \mathrm{~F}$ (XI), two new isomeric alcohols, a chlorohydrin and a diol, were added to this novel class of compounds. Some of these were further derivatized and polymerized.

Epoxides offer a wide variety of possibilities in synthesis through ring-opening reactions. Nucleophilic cleavage of an epoxide $\mathrm{C}-\mathrm{O}$ bond can be achieved under basic, neutral or acidic conditions. In studying ring-opening reactions of this epoxide only reactions in acidic media gave desired products, while basic conditions resulted in loss of the sulfonyl fluoride group. Unsymmetrical epoxides can lead to two different 
products, depending on which $\mathrm{C}-\mathrm{O}$ bond is broken. These possibilities, with the overall addition of a protic nucleophile to a simple monosubstituted epoxide can be illustrated as:

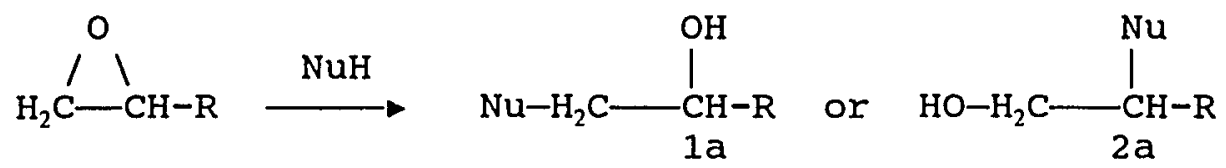

One or the other product usually predominates, depending on the reagents and conditions employed. The regioselectivity of these reactions has been reviewed, and is described in terms of a borderline $S_{N} 2$ transition state in which the C-O bond breaking runs slightly ahead of the Nu-C bond making (63). For cases where $\mathrm{R}$ is electron-withdrawing (as is $O \mathrm{CF}_{2} \mathrm{CF}_{2} \mathrm{SO}_{2} \mathrm{~F}$ ) products of type $1 \mathrm{a}$ predominate, or may be formed exclusively. This is explained through charge distribution and steric effects in the transition states for nucleophilic attack at either site of the protonated epoxide:

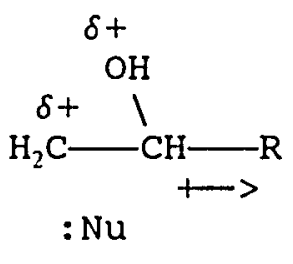

$1 b$

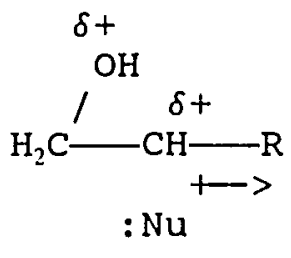

$2 b$

Reaction through the transition state $1 \mathrm{~b}$ is more favorable 
with the developing partial positive charge being farther away from the inductively destabilizing electron withdrawing group. This transition state is also less stericly hindered toward nucleophilic attack.

\section{Fluoroalkyl Acrylate Esters}

other than the new alcohols prepared in this work and discussed below, only one compound containing both alcohol and fluoroalkyl sulfonyl fluoride functional groups has been reported (42). Furthermore, there are no reported acrylate esters containing fluoroalkyl sulfonyl fluoride groups. Extensive work has been performed investigating other fluoroalkyl containing acrylates, mostly at the Minnesota Mining and Manufacturing Company (3M) and DuPont. Many commercial products of this type are available for formulation use in weather-, oil-, and stain-resistant films and coatings; commercially the most important example being $\mathrm{CH}_{2}=\mathrm{CHC}(\mathrm{O}) \mathrm{OCH}_{2} \mathrm{CF}_{2} \mathrm{CF}_{2} \mathrm{CF}_{3}$, used by $3 \mathrm{M}$ to make the product Fluororubber $2 F h(64)$. Exact information about the synthesis of this and other similar commercial products is proprietary and not available.

Esterification of $\mathrm{HOCH}_{2} \mathrm{CH}_{2} \mathrm{CF}_{2} \mathrm{CF}_{2} \mathrm{OCF}_{2} \mathrm{CF}_{2} \mathrm{SO}_{2} \mathrm{~F}$ with acrylic acid was seen as a way to incorporate a fluoroalkyl sulfonyl fluoride group into a readily polymerizable monomer to give a new class of polyacrylates. The reactive intermediate, $\mathrm{CH}_{2}=\mathrm{CHC}(\mathrm{O}) \mathrm{OCH}_{2} \mathrm{CH}_{2} \mathrm{CF}_{2} \mathrm{CF}_{2} \mathrm{OCF}_{2} \mathrm{CF}_{2} \mathrm{SO}_{2} \mathrm{~F}$ (XVI), was successfully 
synthesized. Subsequent polymerization of the product is discussed in a later section.

RING-OPENING REACTIONS OF OCH2CHCH2OCF2CF2SO2F

Using the epoxide $\mathrm{OCH}_{2} \mathrm{CHCH}_{2} \mathrm{OCF}_{2} \mathrm{CF}_{2} \mathrm{SO}_{2} \mathrm{~F}$ (XI), new compounds containing both the $-\mathrm{OCF}_{2} \mathrm{CF}_{2} \mathrm{SO}_{2} \mathrm{~F}$ and hydroxyl groups were prepared. The addition of $\mathrm{HCl}$ lead to the isolation of a single product in $80 \%$ yield, with the orientation as described above: ।

$$
(\mathrm{XI})+\mathrm{HCl} \frac{\mathrm{Et} 2 \mathrm{O}}{\text { reflux }} \longrightarrow \mathrm{ClCH}_{2} \mathrm{CH}(\mathrm{OH}) \mathrm{CH}_{2} \mathrm{OCF}_{2} \mathrm{CF}_{2} \mathrm{SO}_{2} \mathrm{~F}
$$

(XII)

This orientation of ring-opening has been observed in the addition of $\mathrm{HCl}$ to other propylene oxide derivatives with electron withdrawing substituents (62). Analysis of the mass spectrum and infrared data provides support for this structure. The $(\mathrm{m} / \mathrm{z})^{+}$fragments: of 243 and 51 can be unambiguously assigned to $\left(\mathrm{M}-\mathrm{ClCH}_{2}\right)^{+}$and $\left(\mathrm{ClCH}_{2}\right)^{+}$by lack of and presence of a $\mathrm{Cl}$ isotope peak, respectively. The infrared spectrum of (XII), as a neat film, showed a broad hydroxyl band at $3423 \mathrm{~cm}^{-1}$ while the $\mathrm{C}-\mathrm{Cl}$ stretch was found at $710 \mathrm{~cm}^{-1}$ and was is in the reglion expected for a primary alkylchloride (65).

The addition of benzyl alcohol to epoxide (XI), under experimental conditions used in this work, appears to be 
equally favorable at either the terminal or internal site as shown by the product composition:

$$
\begin{aligned}
& (\mathrm{XI})+\mathrm{C}_{6} \mathrm{H}_{5} \mathrm{CH}_{2} \mathrm{OH} \underset{\text { reflux }}{\stackrel{\mathrm{H} 2 \mathrm{SO} / \mathrm{Et} 2 \mathrm{O}}{\mathrm{HOCH}_{2} \mathrm{CHCH}_{2} \mathrm{OCF}_{2} \mathrm{CF}_{2} \mathrm{SO}_{2} \mathrm{~F}}}{\underset{\mathrm{OCH}}{\mathrm{OCH}_{6} \mathrm{H}_{5}} \text { (XIII) }}_{55 \%}^{\mathrm{HIII}} \\
& \mathrm{C}_{6} \mathrm{H}_{5} \mathrm{CH}_{2} \mathrm{OCH}_{2} \mathrm{CHCH}_{2} \mathrm{OCF}_{2} \mathrm{CF}_{2} \mathrm{SO}_{2} \mathrm{~F} \\
& !_{\mathrm{OH}}(\mathrm{XIV}) \quad 45 \%
\end{aligned}
$$

The GC-MS data of the distilled product gave the molecular ion peaks for both products. For one product fraction, the molecular ion had a relative intensity of $27 \%$ and a fragment ion, $(\mathrm{m} / \mathrm{z})^{+}$of $31\left(\mathrm{CH}_{2} \mathrm{OH}\right)^{+}$, which was assigned to product (XIII). The second product fraction had a smaller molecular ion intensity of $2.5 \%$ and had a fragment ion, $(\mathrm{m} / \mathrm{z})^{+}$of 243 $\left(\mathrm{CH}(\mathrm{OH}) \mathrm{CH}_{2} \mathrm{OCF}_{2} \mathrm{CF}_{2} \mathrm{SO}_{2} \mathrm{~F}\right)^{+}$, which was assigned to product (XIV). The ratio of products (XIII) and (XIV) in the mixture is also revealed in the ${ }^{1} \mathrm{H}$ NMR spectrum; at $400 \mathrm{Mhz}$ two distinct pentets at 4.01 and $3.87 \mathrm{ppm}$ for the methine protons with relative integration values of one proton each were found (TABLE IIX). The ${ }^{19} \mathrm{~F}$ NMR spectrum did not show any differences for the two components in the mixture (TABLE IX), while the ${ }^{13} \mathrm{C}$ NMR spectrum revealed separate signals for (XIII) and (XIV) for all but the fluorinated alkyl and aromatic carbons (TABLE X).

The infrared spectrum of the mixture contained a broad hydroxyl band at $3416 \mathrm{~cm}^{-1}$, and weak $\mathrm{C}-\mathrm{H}$ stretches at 3093 
and $3064 \mathrm{~cm}^{-1}$, overtone bands at 1955, 1836, 1810 and 1724 $\mathrm{cm}^{-1}$, and out of plane bending motions at 745 and $700 \mathrm{~cm}^{-1}$ for the aromatic group.

Acid catalyzed hydration of epoxide (XI) by two methods resulted in the diol $\mathrm{HOCH}_{2} \mathrm{CH}(\mathrm{OH}) \mathrm{CH}_{2} \mathrm{OCF}_{2} \mathrm{CF}_{2} \mathrm{SO}_{2} \mathrm{~F}$ (XV):

$$
(\mathrm{XI})+\mathrm{H}_{2} \mathrm{O} \underset{\mathrm{THF} / \text { reflux }}{\stackrel{\mathrm{H} 2 \mathrm{SO} 4}{\mathrm{or}} \text { Nafion }} \rightarrow \mathrm{HOCH}_{2} \mathrm{CHCH}_{2} \mathrm{OCF}_{2} \mathrm{CF}_{2} \mathrm{SO}_{2} \mathrm{~F}
$$

Using Nafion as a solid acid catalyst resulted in a more direct work up of the product and better yield (57\% vs $36 \%$ ). The infrared spectrum of diol (xV) showed the broad hydraxyl stretch at $3381 \mathrm{~cm}^{-1}$ and $\mathrm{C}-\mathrm{H}$ stretches at 2966, 2946 and $2898 \mathrm{~cm}^{-1}$. This diol was a valuable intermediate in the preparation of unique polymeric materials containing the $-\mathrm{OCF}_{2} \mathrm{CF}_{2} \mathrm{SO}_{2} \mathrm{~F}$ group and will be discussed in a later section.

The structures of the ring-opening products were determined, in part, from their ${ }^{1} \mathrm{H},{ }^{19} \mathrm{~F}$, and ${ }^{13} \mathrm{C}$ NMR spectra which are listed in TABLES IIX, IX and $\mathrm{X}$. The ${ }^{1} \mathrm{H}$ NMR spectra of chlorohydrin (XII) and diol (XV), which exhibited second order:effects, were analyzed as an ABMXY spin systems using computer aided simulation in order to determine their respective chemical shifts and coupling constants. For the product mixture of (XIII) and (XIV) this was not done and the tabulated data only specify the designated groups corresponding to each compound. 
The ${ }^{19} \mathrm{~F}$ NMR spectra of the $\mathrm{OCF}_{2} \mathrm{CF}_{2} \mathrm{SO}_{2} \mathrm{~F}$ grouping were very similar in all the products with chemical shift values of 44.2 to $43.0 \mathrm{ppm},-82.9$ to $-85.5 \mathrm{ppm}$ and -113.3 to -116.7 ppm for the $\mathrm{SO}_{2} \mathrm{~F}, \mathrm{OCF}_{2}$, and $\mathrm{CF}_{2} \mathrm{~S}$ groups respectively. These results agree with literature values for other compounds containing these groups $(38,39,51,52,66)$.

All ${ }^{13} \mathrm{C}$ NMR spectra were similar in that the methylene groups nearest the fluoroalkyl groups had chemical shifts ranging from 66.6 to $68.9 \mathrm{ppm}$ and exhibited ' $J_{1}$ coupling of 4.0-4.5 Hz. The methine carbons, recognized as the only doublets in the 'H-coupled spectra, were found in the range of 68.5 to $70.1 \mathrm{ppm}$ and showed similar ${ }^{\prime} J_{H}$ coupling of 141.4 to $143.3 \mathrm{~Hz}$. For the mixture of (XIII) and (XIV) the chemical shift value of $70.0 \mathrm{ppm}$ was assigned to the ether group ( $\mathrm{HCOCH}_{2} \mathrm{C}_{6} \mathrm{H}_{5}$ ) while the value of $68.5 \mathrm{ppm}$ was assigned to the alcohol portion ( $\mathrm{HCOH})$. The $\mathrm{OCF}_{2} \mathrm{CF}_{2} \mathrm{SO}_{2} \mathrm{~F}$ portions of the spectra are all quite similar and agree with published results $(66)$.

The infrared spectra of all the compounds are listed below in the Experimental section. All exhibit the features of the tetrafluoroethyl sulfonyl fluoride group $(38,39,51-$ $53,66)$. The characteristic $\mathrm{SO}_{2}$ asymmetric and symmetric stretching frequencies were found in the $1455-1456$ and 1243 - $1250 \mathrm{~cm}^{-1}$ regions. The $\mathrm{S}-\mathrm{F}$ absorption was found between $810-817 \mathrm{~cm}^{-1}$. The strong carbon fluorine absorption bands found at $1202-1043 \mathrm{~cm}^{-1}$ are attributed to 
the $\mathrm{CF}_{2}$ groups. Bands characteristic of the epoxide ring at 3069 and 3016 (terminal C-H stretch), 1270 (symmetric ring stretch) and $907 \mathrm{~cm}^{-1}$ (asymmetric ring stretch) (67) present in the epoxide (XI) were absent in all products. Mass spectra fragments listed in the experimental section were supportive of the assigned structures. For most compounds the molecular ion peaks were not found. However, the relative instability of the halogenated and hydroxy compounds towards fragmentation was quite helpful in assigning structural isomers as addressed above for these compounds.

Several other ring-opening reactions were attempted for the addition of alcohols to epoxide (XI). Use of alumina doped with alcohols has been reported as being an effective method of incorporating alcohols into epoxides. Activation of the ring system by formation of a Lewis acid-base complex is proposed to be operating in these reactions (68). Near quantitative yields and ease of solution work-up (filtering and washing the $\mathrm{Al}_{2} \mathrm{O}_{3}$ followed by distillation) makes this an attractive synthetic method.

This method was attempted in hopes of isolating a single isomer of the product mixture (XIII) and (XIV), but no desired product was obtained. However, distillation resulted in the isolation of a viscous product for which ${ }^{19} \mathrm{~F}$ NMR spectral data showed loss of the $\mathrm{SO}_{2} \mathrm{~F}$ group suggesting possible formation of a benzyl sulfonate ester. 
Iranpoor and Baltork report the use of cerium(IV) ammonium nitrate catalyst in nucleophilic ring-opening reactions of oxiranes in alcohols give a high degree of regioselectivity (69). A proposed reaction scheme involves the formation of an epoxonium radical cation as shown:

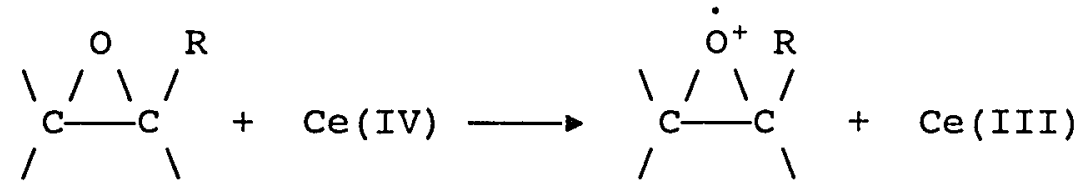

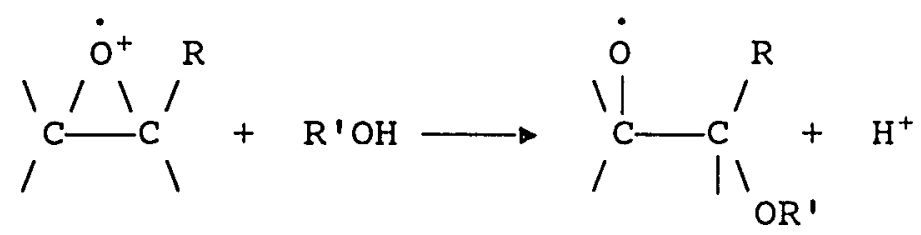

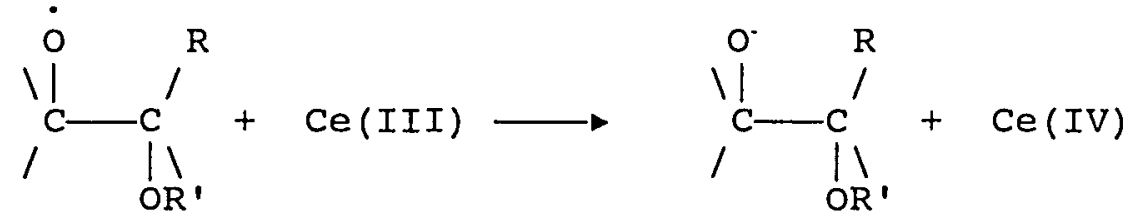<smiles>[R]C([R])([OH2+])C([R])(C)[CH-][IH+]C</smiles>

Reactions of epoxide (XI) with phenol and benzyl alcohol using cerium (IV) ammonium nitrate resulted in the isolation of only unreacted starting materials. 
TABLE IIX

${ }^{1} \mathrm{H}$ NMR DATA FOR COMPOUNDS $\mathrm{R}^{1} \mathrm{CH} 2 \mathrm{CH}\left(\mathrm{R}^{2}\right) \mathrm{CH} 2 \mathrm{OCF} 2 \mathrm{CF} 2 \mathrm{SO} 2 \mathrm{~F}$ : $\mathrm{ClCH} 2 \mathrm{CH}(\mathrm{OH}) \mathrm{CH} 2 \mathrm{OCF} 2 \mathrm{CF} 2 \mathrm{SO} 2 \mathrm{~F}$ (XII);

$\mathrm{HOCH} 2 \mathrm{CH}$ (OCH2 $6 \mathrm{H} 5$ ) $\mathrm{CH}_{2} \mathrm{OCF} 2 \mathrm{CF} 2 \mathrm{SO} 2 \mathrm{~F}$ (XIII); $\mathrm{C} 6 \mathrm{H} 5 \mathrm{CH} 2 \mathrm{OCH} 2 \mathrm{CH}(\mathrm{OH}) \mathrm{CH} 2 \mathrm{OCF} 2 \mathrm{CF} 2 \mathrm{SO} 2 \mathrm{~F}$ (XIV); AND $\mathrm{HOCH} 2 \mathrm{CH}(\mathrm{OH}) \mathrm{CH} 2 \mathrm{OCF} 2 \mathrm{CF} 2 \mathrm{SO} 2 \mathrm{~F}(\mathrm{XV})^{\mathrm{a}}$

\begin{tabular}{|c|c|c|c|c|c|}
\hline $\mathrm{R}^{1}$ & $\mathrm{R}^{2}$ & $\mathrm{R}^{1} \mathrm{CH} 2$ & CHR2 & & $\mathrm{CH} 2 \mathrm{O}$ \\
\hline \multicolumn{6}{|c|}{$\mathrm{ClCH} 2 \mathrm{CH}(\mathrm{OH}) \mathrm{CH} 2 \mathrm{OCF} 2 \mathrm{CF} 2 \mathrm{SO} 2 \mathrm{~F}$ (XII) } \\
\hline Cl & $\mathrm{HO}^{b}$ & $\begin{array}{l}X 3.68(d, d) \\
Y 3.66(d, d) \\
J X-Y=11.2 \\
J X-C=0.7 \\
J Y-C=5.7\end{array}$ & $M: 4.15(d, d, d, d)$ & $\begin{array}{l}A \\
B\end{array}$ & $\begin{array}{l}4.23(d, d) \\
4.21(d, d) \\
J A-B=9.9 \\
J A-C=7.5 \\
J B-C=3.6\end{array}$ \\
\hline
\end{tabular}
$\begin{array}{ll}\mathrm{HOCH} 2 \mathrm{CH}(\mathrm{OCH} 2 \mathrm{C} 6 \mathrm{H} 5) \mathrm{CH} 2 \mathrm{OCF} 2 \mathrm{CF} 2 \mathrm{SO} 2 \mathrm{~F} & \text { (XIII) and } \\ \mathrm{C} 6 \mathrm{H} 5 \mathrm{CH} 2 \mathrm{OCH} 2 \mathrm{CH}(\mathrm{OH}) \mathrm{CH} 2 \mathrm{OCF} 2 \mathrm{CF} 2 \mathrm{SO} 2 \mathrm{~F} & \text { (XIV) }^{c}\end{array}$
( $\left.6 \mathrm{H}_{5} \mathrm{CH} 2 \mathrm{O}\right)$
$3.54(\mathrm{~m})$
$14.01(\mathrm{p})$
$4.22(\mathrm{~m})$
aromatic
$3.53(\mathrm{~m})$
$13.87(\mathrm{p})$
$4.16(\mathrm{~m})$
$7.35(\mathrm{~m})$
benzylic
$4.55(\mathrm{~s})$
$4.53(\mathrm{~s})$
$\mathrm{HO}^{\mathrm{d}}$

$\mathrm{HOCH} 2 \mathrm{CH}(\mathrm{OH}) \mathrm{CH} 2 \mathrm{OCF} 2 \mathrm{CF} 2 \mathrm{SO} 2 \mathrm{~F}$ (XV)
$\mathrm{HO} \mathrm{HO}^{\mathrm{e}}$
A $4.19(d, d)$
B $4.11(d, d)$
$J_{A-B}=10.2$
$J_{A}-M=4.4$
$J \mathrm{~B}-\mathrm{M}=6.0$
$M \mid 3.86(d, d, d, d)$
$X 3.55(d, d)$
Y 3.51
$J X-Y=11.4$
$J X-M=4.9$
$J Y-M=5.7$

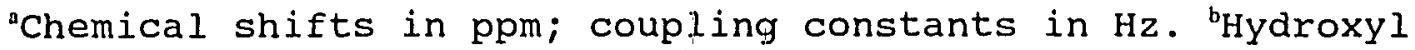
proton observed at $2.85 \mathrm{ppm}$ in $C D C l_{3}$. ${ }^{\mathrm{c}} \mathrm{From}$ unseparated mixture of (XIII) and (XIV). "Hydroxyl proton observed at $3.2 \mathrm{ppm}$ in $\mathrm{CD}_{3} \mathrm{CN}$. "Hydroxyl protons observed at $4.3 \mathrm{ppm}$ in $\mathrm{CDCl}_{3}$ and under $\mathrm{H}^{\mathrm{X}}$ and $\mathrm{H}^{\mathrm{Y}}$ peaks in $\mathrm{CD}_{3} \mathrm{CN}$. 
TABLE IX

${ }^{19} \mathrm{~F}$ NMR DATA FOR COMPOUNDS $\mathrm{R}^{1} \mathrm{CH} 2 \mathrm{CH}\left(\mathrm{R}^{2}\right) \mathrm{CH} 2 \mathrm{OCF} 2 \mathrm{CF} 2 \mathrm{SO} 2 \mathrm{~F}$ :

$\mathrm{ClCH} 2 \mathrm{CH}(\mathrm{OH}) \mathrm{CH} 2 \mathrm{OCF} 2 \mathrm{CF} 2 \mathrm{SO} 2 \mathrm{~F}$ (XII);

$\mathrm{HOCH} 2 \mathrm{CH}$ (OCH2C6H5) $\mathrm{CH} 2 \mathrm{OCF} 2 \mathrm{CF} 2 \mathrm{SO} 2 \mathrm{~F}$ (XIII); $\mathrm{C} 6 \mathrm{H} 5 \mathrm{CH} 2 \mathrm{OCH} 2 \mathrm{CH}(\mathrm{OH}) \mathrm{CH} 2 \mathrm{OCF} 2 \mathrm{CF} 2 \mathrm{SO} 2 \mathrm{~F}$ (XIV); AND $\mathrm{HOCH} 2 \mathrm{CH}(\mathrm{OH}) \mathrm{CH} 2 \mathrm{OCF} 2 \mathrm{CF} 2 \mathrm{SO} 2 \mathrm{~F}$ (XV)

\begin{tabular}{|c|c|c|c|c|}
\hline $\mathrm{R}^{1}$ & $\mathrm{R}^{2}$ & $O C F 2^{a}$ & $\mathrm{CF} 2 \mathrm{~b}^{\mathrm{S}}$ & $\mathrm{SO} 2 \mathrm{~F}^{\mathrm{c}}$ \\
\hline \multicolumn{5}{|c|}{$\mathrm{C} 1 \mathrm{CH} 2 \mathrm{CH}(\mathrm{OH}) \mathrm{CH} 2 \mathrm{OCF} 2 \mathrm{CF} 2 \mathrm{SO} 2 \mathrm{~F}$ (XII) } \\
\hline $\mathrm{Cl}$ & $\mathrm{OH}$ & $\begin{array}{l}-82.9(d, t) \\
J F^{b}=5.1\end{array}$ & $\begin{array}{l}-113.6(d, t) \\
J F^{c}=5.1\end{array}$ & $\begin{array}{l}44.2(t, t) \\
J F^{n}=4.8\end{array}$ \\
\hline \multicolumn{3}{|c|}{$\begin{array}{l}\mathrm{HOCH} 2 \mathrm{CH}(\mathrm{OCH} 2 \mathrm{C} 6 \mathrm{H} 5) \mathrm{CH} 2 \mathrm{OCF} 2 \mathrm{CF} 2 \mathrm{SO} 2 \mathrm{~F} \\
\mathrm{C} 6 \mathrm{H} 5 \mathrm{CH} 2 \mathrm{OCH} 2 \mathrm{CH}(\mathrm{OH}) \mathrm{CH} 2 \mathrm{OCF} 2 \mathrm{CF} 2 \mathrm{SO} 2 \mathrm{~F}\end{array}$} & $\begin{array}{l}(\mathrm{XIII}) \text { and } \\
(\mathrm{XIV})\end{array}$ & \\
\hline (C6) & $5 \mathrm{CH} 2 \mathrm{O} / \mathrm{HO})$ & $\begin{array}{l}-82.9(d, t) \\
J F^{b}=4.0\end{array}$ & $\begin{array}{l}-116.7(d, t) \\
J F^{c}=5.2\end{array}$ & $\begin{array}{l}43.9(t, t) \\
J F^{a}=5.4\end{array}$ \\
\hline
\end{tabular}

$\mathrm{HOCH} 2 \mathrm{CH}(\mathrm{OH}) \mathrm{CH} 2 \mathrm{OCF} 2 \mathrm{CF} 2 \mathrm{SO} 2 \mathrm{~F}$ (XV)

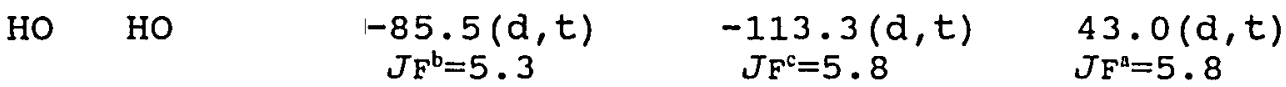

"Chemical shifts in ppm; coupling constants in $\mathrm{Hz}$.

* From unseparated mixture of (XIII) and (XIV). 
TABLE X

${ }^{13} \mathrm{C}-\mathrm{NMR}$ DATA FOR COMPOUNDS $\mathrm{R}^{1} \mathrm{CH} 2 \mathrm{CH}\left(\mathrm{R}^{2}\right) \mathrm{CH} 2 \mathrm{OCF} 2 \mathrm{CF} 2 \mathrm{SO} 2 \mathrm{~F}: \mathrm{ClCH} 2 \mathrm{CH}(\mathrm{OH}) \mathrm{CH} 2 \mathrm{OCF} 2 \mathrm{CF} 2 \mathrm{SO} 2 \mathrm{~F}$ (XII); $\mathrm{HOCH} 2 \mathrm{CH}(\mathrm{OCH} 2 \mathrm{C} 6 \mathrm{H} 5) \mathrm{CH} 2 \mathrm{OCF} 2 \mathrm{CF} 2 \mathrm{SO} 2 \mathrm{~F}$ (XIII); $\mathrm{C} 6 \mathrm{H} 5 \mathrm{CH} 2 \mathrm{OCH} 2 \mathrm{CH}(\mathrm{OH}) \mathrm{CH} 2 \mathrm{OCF} 2 \mathrm{CF} 2 \mathrm{SO} 2 \mathrm{~F}$ (XIV); AND $\mathrm{HOCH} 2 \mathrm{CH}(\mathrm{OH}) \mathrm{CH} 2 \mathrm{OCF} 2 \mathrm{CF} 2 \mathrm{SO}_{2} \mathrm{~F}$ (XV)

\begin{tabular}{|c|c|c|c|c|c|c|}
\hline $\mathrm{R}^{1}$ & $\mathrm{R}^{2}$ & $\mathrm{R}^{1} \mathrm{CH} 2^{2}$ & $\mathrm{CH}^{\mathrm{b}} \mathrm{R}^{2}$ & $\mathrm{CH} 2^{\mathrm{c} O}$ & $C F 2^{d}$ & $\mathrm{CF}_{2}{ }^{\mathrm{eSO}} 2 \mathrm{~F}^{\mathrm{e}}$ \\
\hline \multicolumn{7}{|c|}{$\mathrm{C} 1 \mathrm{CH} 2 \mathrm{CH}(\mathrm{OH}) \mathrm{CH}_{2} \mathrm{OCF} 2 \mathrm{CF} 2 \mathrm{SO} 2 \mathrm{~F}$ \{XII\} } \\
\hline $\mathrm{Cl}$ & но & $44.9(s)$ & $68.9(s)$ & $\begin{array}{l}66.6(t) \\
J F^{d}=4.2\end{array}$ & $\begin{array}{l}116.0(t, t, d) \\
J F^{d}=275.9 \\
J F^{c}=28.0 \\
J F^{f}=3.8\end{array}$ & $\begin{array}{l}113.7(t, t, d) \\
J F^{e}=301.8 \\
J F^{d}=41.6 \\
J F^{f}=34.4\end{array}$ \\
\hline \multicolumn{7}{|c|}{$\mathrm{HOCH} 2 \mathrm{CH}(\mathrm{OCH} 2 \mathrm{C} 6 \mathrm{H} 5) \mathrm{CH} 2 \mathrm{OCF} 2 \mathrm{CF} 2 \mathrm{SO} 2 \mathrm{~F}$ (XIII) ${ }^{*}$} \\
\hline но & $\begin{array}{l}\mathrm{C} 6 \mathrm{H} 5 \mathrm{CH} 2 \\
\text { benzylic } \\
73.9(\mathrm{~s}) \\
\text { aromatic } \\
129.2(\mathrm{~s}) \\
128.6(\mathrm{~s}) \\
128.5(\mathrm{~s}) \\
128.4(\mathrm{~s})\end{array}$ & $62.9(s)$ & $70.0(s)$ & $\begin{array}{l}68.8(t) \\
J F^{d}=4.0\end{array}$ & $\begin{array}{l}116.9(t, t, d) \\
J F^{d}=271.3 \\
J F^{c}=27.5 \\
J F^{f}=3.5\end{array}$ & $\begin{array}{l}114.5(t, t, d) \\
J F^{e}=291.7 \\
J F^{d}=42.8 \\
J F^{f}=30.2\end{array}$ \\
\hline \multicolumn{7}{|c|}{$\mathrm{C} 6 \mathrm{H} 5 \mathrm{CH} 2 \mathrm{OCH} 2 \mathrm{CH}(\mathrm{OH}) \mathrm{CH} 2 \mathrm{OCF} 2 \mathrm{CF} 2 \mathrm{SO} 2 \mathrm{~F}$ (XIV) ${ }^{*} ;$} \\
\hline $\begin{array}{l}\mathrm{C} 6 \mathrm{H} 5 \mathrm{CH} 2 \\
\text { benzylic } \\
72.8(\mathrm{~s}) \\
\text { aromatic } \\
\text { same as }\end{array}$ & III) & $71.7(\mathrm{~s})$ & $68.5(s)$ & $68.9(t)$ & same as & $(X I I I)$ \\
\hline
\end{tabular}


TABLE X

${ }^{13} \mathrm{C}-\mathrm{NMR}$ DATA FOR COMPOUNDS $\mathrm{R}^{1} \mathrm{CH} 2 \mathrm{CH}\left(\mathrm{R}^{2}\right) \mathrm{CH} 2 \mathrm{OCF} 2 \mathrm{CF} 2 \mathrm{SO} 2 \mathrm{~F}: \mathrm{ClCH} 2 \mathrm{CH}(\mathrm{OH}) \mathrm{CH} 2 \mathrm{OCF} 2 \mathrm{CF} 2 \mathrm{SO} 2 \mathrm{~F}$ (XII); $\mathrm{HOCH} 2 \mathrm{CH}(\mathrm{OCH} 2 \mathrm{C} 6 \mathrm{H} 5$ ) $\mathrm{CH} 2 \mathrm{OCF} 2 \mathrm{CF} 2 \mathrm{SO} 2 \mathrm{~F}$ (XIII); $\mathrm{C} 6 \mathrm{H} 5 \mathrm{CH} 2 \mathrm{OCH} 2 \mathrm{CH}(\mathrm{OH}) \mathrm{CH} 2 \mathrm{OCF} 2 \mathrm{CF} 2 \mathrm{SO} 2 \mathrm{~F}$ (XIV); AND $\mathrm{HOCH} 2 \mathrm{CH}(\mathrm{OH}) \mathrm{CH} 2 \mathrm{OCF} 2 \mathrm{CF} 2 \mathrm{SO} 2 \mathrm{~F}$ (XV)

continued

\begin{tabular}{|c|c|c|c|c|c|c|}
\hline $\mathrm{R}^{1}$ & $\mathrm{R}^{2}$ & $\mathrm{R}^{\prime} \mathrm{CH} 2^{\mathrm{a}}$ & $\mathrm{CH}^{\mathrm{b}} \mathrm{R}^{2}$ & $\mathrm{CH} 2^{\mathrm{c}} \mathrm{O}-$ & $\mathrm{CF}_{2}{ }^{\mathrm{d}}$ & $\mathrm{CF}_{2}{ }^{\mathrm{C}} \mathrm{SO} 2 \mathrm{~F}^{\mathrm{f}}$ \\
\hline \multicolumn{7}{|c|}{$\mathrm{HOCH} 2 \mathrm{CH}(\mathrm{OH}) \mathrm{CH} 2 \mathrm{OCF} 2 \mathrm{CF} 2 \mathrm{SO} 2 \mathrm{~F}$ (XV) } \\
\hline Ho & HO & $63.0(5)$ & $70.1(\mathrm{~s})$ & $\begin{array}{l}68.7(t) \\
J F^{c}=4.1\end{array}$ & $\begin{array}{l}116.9(t, t, d) \\
J F^{d}=273.4 \\
J F^{c}=27.9 \\
J F^{f}=3.7\end{array}$ & $\begin{array}{l}114.6(t, t, d) \\
T F^{c}=300.5 \\
J F^{f}=42.7 \\
J F^{d}=34.3\end{array}$ \\
\hline
\end{tabular}

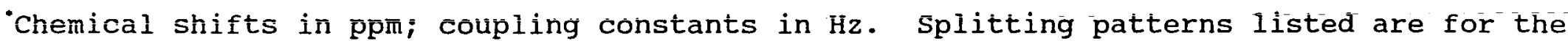
proton-decoupled spectra. In the coupled spectra the following additional splitting patterns and coupling constants found were: (XII) $C_{1 C H}(t, d, t) J H^{a}=151.5, J H^{b}<2.0$, $J H^{c}=3.5, C H(O H) \quad(d, p) J H^{b}=141.4, J H^{c}=J H^{b}=3.0, C_{H} \mathrm{O}(t, d) J H^{c}=151.1, J H^{b}=10.3 ;$

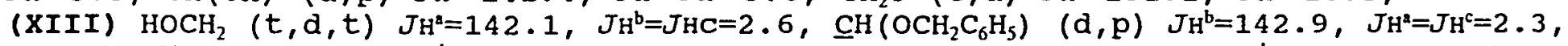

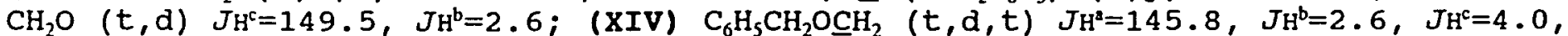

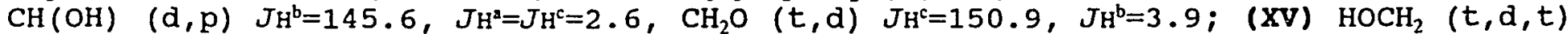
$J H^{a}=142.3, J H^{b}=J H^{c}=2.6, C H(O H)(d, p) J H^{b}=143.3, J H^{a}=J H^{c}=2.4, C H_{2} \mathrm{O}(t, d) J H^{c}=149.4, J H^{b}=5.5$. "From unseparated mixture of (XIII) and (XIV). 
FLUOROACRYLATE ESTER $\mathrm{CH} 2=\mathrm{CHC}(\mathrm{O}) \mathrm{OCH} 2 \mathrm{CH} 2 \mathrm{CF} 2 \mathrm{CF} 2 \mathrm{OCF} 2 \mathrm{CF} 2 \mathrm{SO} 2 \mathrm{~F}$ (XVI)

Due to the acidic character of fluoroalcohols, direct esterification is usually not used in the synthesis of their esters. Two methods for the preparation of acrylate esters from fluoroalcohols are: 1) the use of acrylyl chloride with an amine or other proton acceptor; and 2) the use of equimolar amounts of trifluoroacetic anhydride with acrylic acid (70). The acrylate reported here was successfully synthesized by the latter method:

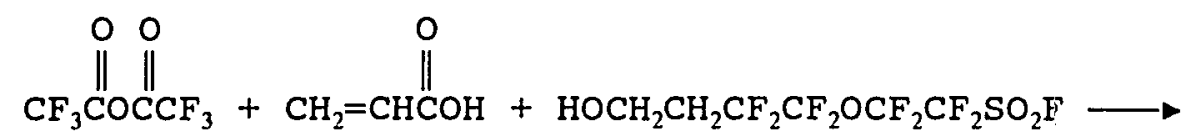

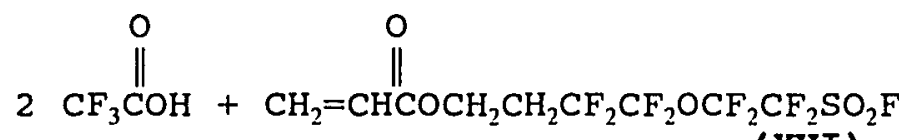

The use of acryloyl chloride and pyridine did not produce the desired product but instead loss of the sulfonyl fluoride group with possible formation of a pyridinium fluoride occurred:

$\mathrm{HOCH}_{2} \mathrm{CH}_{2} \mathrm{CF}_{2} \mathrm{CF}_{2} \mathrm{OCF}_{2} \mathrm{CF}_{2} \mathrm{SO}_{2} \mathrm{~F}+\mathrm{C}_{5} \mathrm{H}_{5} \mathrm{~N}: \longrightarrow$

$$
\mathrm{HOCH}_{2} \mathrm{CH}_{2} \mathrm{CF}_{2} \mathrm{CF}_{2} \mathrm{OCF}_{2} \mathrm{CF}_{2} \mathrm{SO}_{2} \mathrm{~N}^{+} \mathrm{C}_{5} \mathrm{H}_{5} \quad \mathrm{~F}^{-}
$$

as suggested by loss of the $\mathrm{SO}_{2} \mathrm{~F}{ }^{19} \mathrm{~F}$ NMR signal and appearance of a possible fluoride ion signal at $-126.2 \mathrm{ppm}$. Spectral data for (XVI) is listed in the Experimental 
Section and confirms the structure of the ester. The infrared spectrum was similar to that of the alcohol with the exception that no $\mathrm{O}-\mathrm{H}$ stretching or bending was observed. The carbon-oxygen stretching motion seen as a medium band at $1051 \mathrm{~cm}^{-1}$ in the alcohol was also absent; no new band attributable for a similar motion in the ester could be assigned due to many intense bands in this region. Very weak and medium bands at 3044 and $1411 \mathrm{~cm}^{-1}$ were assigned to olefinic carbon-hydrogen stretching and scissoring motions, respectively. The conjugated carbonoxygen and carbon-carbon stretchings were seen at 1735 and $1639 \mathrm{~cm}^{-1}$. The characteristic features of the tetrafluoroethyl sulfonyl fluoride group $(38,39,51-53,66)$ include: the $\mathrm{SO}_{2}$ asymmetric and symmetric stretching frequencies found at 1464 and $1247 \mathrm{~cm}^{-1}$; the S-F absorption at $811 \mathrm{~cm}^{-1}$; the strong carbon fluorine absorption bands at 1210-1082 $\mathrm{cm}^{-1}$ attributed to the $\mathrm{CF}_{2}$ groups.

The NMR spectra of (XVI) are conisistent with the structure. In the ${ }^{1} \mathrm{H}$ spectrum, (TABLE XI), the olefinic protons appeared in the range of $6: 2-7.0 \mathrm{ppm}$ as an unresolved second-order multiplet. The remaining signals showed similar chemical shifts and coupling constants as the alcohol with the notable shift of the $\mathrm{C}(\mathrm{O}) \mathrm{OC} \mathrm{H}_{2}$ protons to $4.8 \mathrm{ppm}$ in the ester as compared to $3.6 \mathrm{ppm}$ for the $\mathrm{HOCH}_{2}$ protons in the alcohol. The ${ }^{19} \mathrm{~F}$ spectrum was very similar to that reported for the alcohol and is presented in TABLE XI. 
The ${ }^{13} \mathrm{C}$ NMR spectrum, listed in TABLE XII, revealed chemical shifts and coupling constants for the $-\mathrm{OCF}_{2} \mathrm{CF}_{2} \mathrm{SO}_{2} \mathrm{~F}$ carbons similar to those reported for other compounds with this group (66). The $\mathrm{CH}_{2}=\mathrm{CHC}(0) \mathrm{OCH}_{2} \mathrm{CH}_{2} \mathrm{CF}_{2} \mathrm{CF}_{2}$ - portion showed the ${ }^{1} J_{H}$ and ${ }^{1} J_{F}$ splitting patterns expected for the structure. ${ }^{2} J_{\mathrm{F}}$ couplings were found for the $-\mathrm{CH}_{2} \mathrm{CF}_{2} \mathrm{CF}_{2} \mathrm{O}-$ carbons as well. Mass spectral data showed a molecular fragment. Other important fragments are listed in the experimental section. Another route towards the synthesis of a different acrylate ester not involving the use of a fluoroalcohol was attempted. Pfeffer and silbert report high yields by direct esterifications of alkyl halides using sodium, mercury or silver carboxylates in polar aprotic solvent (71). Esterification of 5-bromo-1,1,2,2, tetrafluoro-3-oxa-1sulfonyl fluoride with sodium acrylate was attempted using hexamethylphosphoramide as solvent:<smiles>C=CC(=O)O[18CH]CBr</smiles><smiles>C=CC(=O)OCCOC(F)F</smiles>

No product was isolated. Instead a thick brown oily residue was formed. Loss of the $\mathrm{SO}_{2} \mathrm{~F}{ }^{19} \mathrm{~F}$ NMR signal suggests possible formation of a sulfonamide type product: 


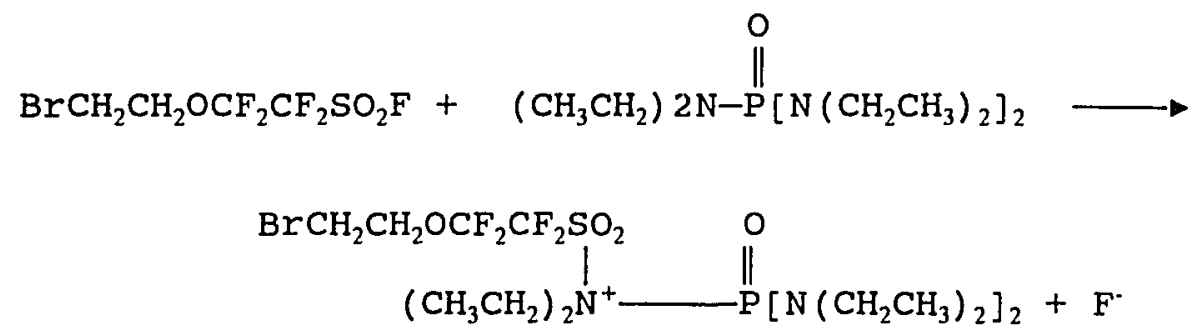


TABLE XI

${ }^{1} \mathrm{H}$ and ${ }^{19} \mathrm{~F}$ NMR data for $\mathrm{CH} 2=\mathrm{CHC}(\mathrm{O}) \mathrm{OCH} 2 \mathrm{CH} 2 \mathrm{CF} 2 \mathrm{CF} 2 \mathrm{OCF} 2 \mathrm{CF} 2 \mathrm{SO} 2 \mathrm{~F}$ (XVI)・

\begin{tabular}{|c|c|c|c|c|c|c|c|}
\hline $\mathrm{CH} 2^{\mathrm{a}}=\mathrm{CH}^{\mathrm{b}}$ & $\mathrm{OCH} 2^{\mathrm{c}}$ & $\mathrm{CH}_{2}{ }^{\mathrm{d}}$ & $\mathrm{CF}^{\mathrm{e}}$ & $C F 2^{\mathrm{f} O}$ & $\mathrm{CF}_{2}{ }^{\mathrm{B}}$ & $\mathrm{CF} 2^{\mathrm{h} S}$ & $\mathrm{SO}_{2} \mathrm{~F}^{\mathrm{i}}$ \\
\hline $7.0-6.2(\mathrm{~m})$ & $\begin{array}{l}4.8(t) \\
J H^{d}=6.6\end{array}$ & $\begin{array}{l}2.8(t, t) \\
J F^{c}=18.2\end{array}$ & $\begin{array}{c}-118.7(t, t) \\
J F^{f}=17.8\end{array}$ & $\begin{array}{c}-89.1(t, t) \\
J F^{g}=6.2\end{array}$ & $-83.5(\mathrm{~m})$ & $\begin{array}{l}-113.5(d, t) \\
J F^{8}=5.1\end{array}$ & $\begin{array}{l}45.7(t, t) \\
J F^{g}=6.3 \\
J F^{i}=6.3\end{array}$ \\
\hline
\end{tabular}

- Chemical shifts in ppm; coupling constants in $\mathrm{Hz}$.

TABLE XII

${ }^{13} \mathrm{C}$ NMR data for $\mathrm{CH} 2=\mathrm{CHC}(\mathrm{O}) \mathrm{OCH} 2 \mathrm{CH} 2 \mathrm{CF} 2 \mathrm{CF} 2 \mathrm{OCF} 2 \mathrm{CF} 2 \mathrm{SO} 2 \mathrm{~F}$ (XVI) ${ }^{*}$

\begin{tabular}{|c|c|c|c|c|c|c|c|c|}
\hline $\mathrm{CH} 2^{\mathrm{a}}=$ & $=\mathrm{CH}^{\mathrm{b}}$ & $c(0)$ & $\mathrm{OCH} 2^{\mathrm{C}}$ & $\mathrm{CH}_{2}{ }^{\mathrm{d}}$ & $C F 2^{e}$ & $C F 2^{f O}$ & $\mathrm{CF}{ }^{\mathrm{B}}$ & $\mathrm{CF} 2^{\mathrm{h}} \mathrm{SO}_{2} \mathrm{~F}^{\mathrm{i}}$ \\
\hline \multirow[t]{2}{*}{$131.1(5)$} & 127.7 (s) & $164.6(5)$ & $55.9(\mathrm{~s})$ & $30.0(t)$ & $114.9(t, t)$ & $117.4(t, t)$ & $114.8(t, t)$ & $112.4(t, t, d)$ \\
\hline & & & & $J_{F^{c}}=21.7$ & $\begin{array}{l}J F^{c}=270.8 \\
J F^{f}=34.0\end{array}$ & $\begin{aligned} J F^{l} & =289.3 \\
J F^{e} & =35.0\end{aligned}$ & $\begin{array}{l}J_{F^{B}}=289.1 \\
J_{F^{h}}=31.0\end{array}$ & $\begin{array}{l}J F^{\mathrm{h}}=302.8 \\
J F^{\mathrm{g}}=38.1 \\
J F^{i}=38.1\end{array}$ \\
\hline
\end{tabular}

- Chemical shifts in ppm; coupling constants in $\mathrm{Hz}$. Splitting patterns listed are for the proton-decoupled spectrum. In the proton-coupled spectrum the 'JH splitting

patterns and coupling constants were: $\mathrm{CH}_{2}=(t), 155.9 ;=\mathrm{CH}(d), 161.1 ; \mathrm{OCH}_{2}(t), 150.4$; $\mathrm{CH}_{2}(t), 130.9$. 
POLYMERIC COMPOUNDS

While the desired polymeric products formed from the reactive intermediates described in this work were films formed in situ, not all products were solids. Polymerization of the epoxide monomer $\mathrm{CH}_{2} \mathrm{CHCH}_{2} \mathrm{OCF}_{2} \mathrm{CF}_{2} \mathrm{SO}_{2} \mathrm{~F}$ (XI) under various conditions lead to viscous liquid products. Using a diepoxide as a cross-linking agent, however, gave freestanding films formed in situ via photo-initiated copolymerization. The diol, $\mathrm{HOCH}_{2} \mathrm{CH}(\mathrm{OH}) \mathrm{CH}_{2} \mathrm{OCF}_{2} \mathrm{CF}_{2} \mathrm{SO}_{2} \mathrm{~F}$ (XV), was used to form two polymeric materials.। A polyester based on the diol and hexafluoroglutaric anhydride was obtained as a viscous liquid, while the successful synthesis of a solid polyurethane resulted from the in situ thermal polymerization of the diol and 1,6-diisocyanohexane. The acrylate ester $\mathrm{CH}_{2}=\mathrm{CHC}(\mathrm{O}) \mathrm{OCH}_{2} \mathrm{OCH}_{2} \mathrm{CH}_{2} \mathrm{CF}_{2} \mathrm{CF}_{2} \mathrm{OCF}_{2} \mathrm{CF}_{2} \mathrm{SO}_{\mathrm{F}}$ (XVI) was polymerized with a free-radical initiator in solution and bulk to give a viscous liquid product and as an in situ formed film.

\section{Polymerization of Epoxides}

Epoxide polymers possess a unique combinations of properties (easy polymerization, low shrinkage, high adhesive strength, good mechanical properties, and chemical resistance) (72). Ethylene oxide and many of its derivatives polymerize in the presence of anionic, cationic, 
and Lewis acid catalysts (73).

Anionic catalysts include alkoxides, hydroxides, metal oxides, and organometallic species such as zinc alkyl compounds. Anionic polymerization can be depicted as shown below using sodium hydroxide as catalyst, where the alkoxide intermediates formed subsequently act as nucleophiles and attack unreacted rings as the polymer chain grows:

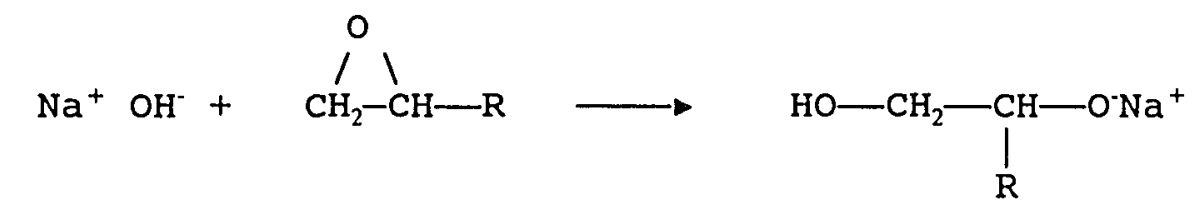<smiles>[R]C(CO)OCC([R])O[18O]C([R])CO</smiles><smiles>[R]C(COC([R])CO)O[Na]</smiles>

Cationic polymerization, depicted below using a general acid HA, is believed to follow two possible mechanisms. The first involves activation of the ring to form an epoxonium ion which is then attacked by oxygen in another ring:

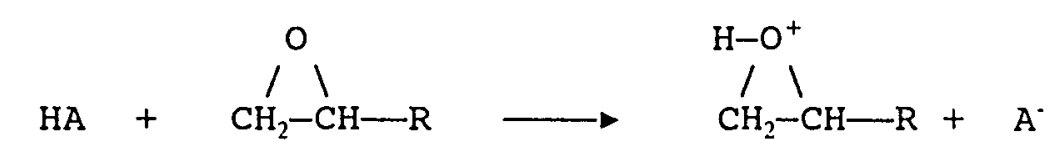<smiles>[R]C(O)C[O+]1CC1[R]</smiles> 
etc

$\mathrm{A}-\left(\mathrm{CH}_{2}-\mathrm{CH}-\mathrm{O}\right)_{\mathrm{n}}-\mathrm{CH}_{2}-\mathrm{CH}-\mathrm{OH}$

The other possible mechanism involves addition of the acid to give an initial ring-opened product which then undergoes typical nucleophilic attack by oxygen in another ring:

$$
\begin{aligned}
& \mathrm{HA}+\stackrel{/}{\stackrel{\mathrm{O}}{\mathrm{CH}}-\mathrm{CH}-\mathrm{R}} \longrightarrow \mathrm{A}-\mathrm{CH}_{2}-\left.\right|_{\mathrm{R}} ^{\mathrm{CH}}-\mathrm{OH}
\end{aligned}
$$

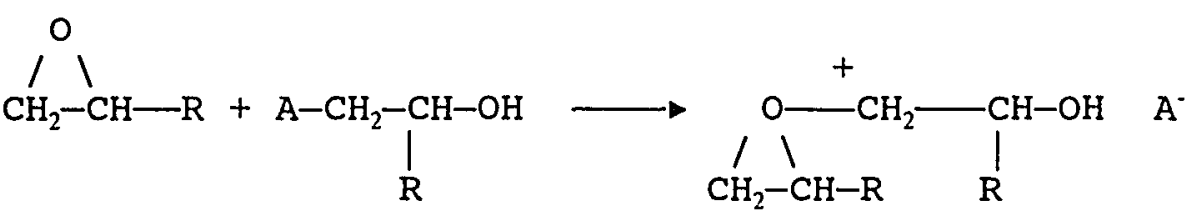

$$
\begin{aligned}
& \text { etc. } \longrightarrow \mathrm{A}-\left(\mathrm{CH}_{2}-\left.\right|_{\mathrm{R}} ^{\mathrm{CH}}-\mathrm{O}\right)_{\mathrm{n}}-\mathrm{CH}_{2}-\mathrm{CH}-\mathrm{OH}
\end{aligned}
$$

Polymerization using Lewis acid catalysts is also believed to follow two possible mechanisms depending on the presence of co-catalytic amounts of trace water. The first mechanism depicted below represents the use of boron trifluoride with water as co-catalyst. The initially formed boron trifluoride-water adduct acts as the protic acid shown above:

$$
\mathrm{H}_{2} \mathrm{O}+\mathrm{BF}_{3} \longrightarrow \mathrm{H}_{2} \mathrm{O}^{+}-\mathrm{B}^{-} \mathrm{F}_{3}
$$

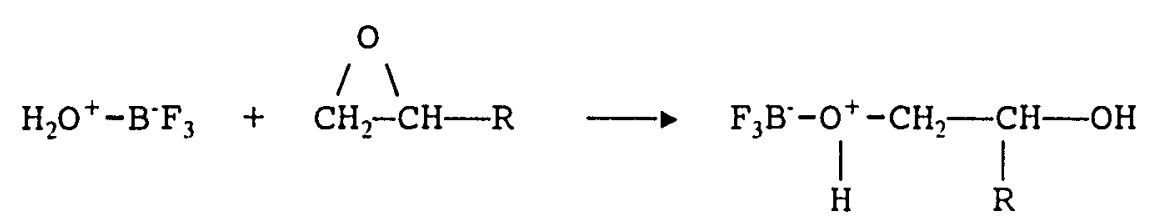




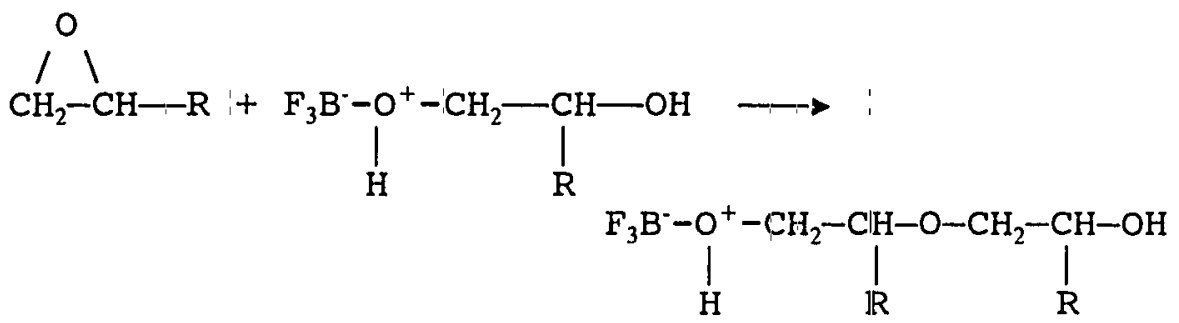

etc $\left.\longrightarrow\right|_{\mathrm{H}} \mathrm{F}_{3} \mathrm{~B}_{\mathrm{R}}^{-}-\mathrm{O}^{+}-\mathrm{CH}_{2}-\mathrm{CH}-\mathrm{O}-\left(\mathrm{CH}_{2}-\left.\right|_{\mathrm{R}} ^{\mathrm{CH}-\mathrm{O})_{\mathrm{n}}-\mathrm{H}}\right.$

In the absence of water, formation of a Lewis acid-base adduct invalving the ring-oxygen is proposed to be the active species:

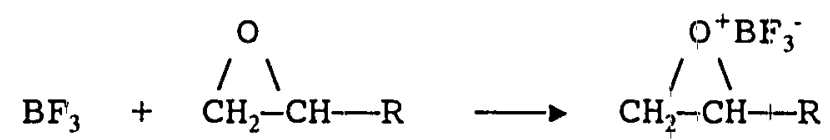

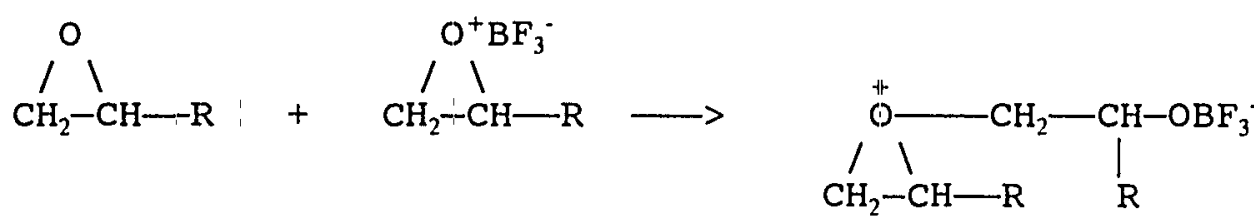

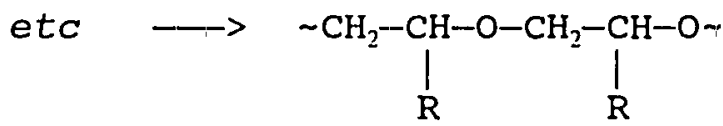

\section{Polyesters:}

Polyesters find use in a variety of fields including fibers, coatings, plastisizers and adhesives. Polyesters are synthesized by typical esterification reactions, which can be generalized as shown: 
$\mathrm{Nu}:+\stackrel{\mathrm{O}}{\|} \stackrel{\mathrm{C}-\mathrm{X}}{\longrightarrow} \stackrel{\mathrm{O}}{\|} \stackrel{\mathrm{C}-\mathrm{Nu}}{\longrightarrow}+\mathrm{X}$

where $\mathrm{Nu}$ : is a nucleophilic reactant and the substrate, $\mathrm{RC}(0) \mathrm{x}$, is a carboxylic acid or derivative. The major synthesis methods for preparing polyesters are represented below in TABLE XIII showing the various nucleophilic species and the carboxylic acid or derivative (74). Functionality greater than two in the nucleophile or substrate leads to cross-linked polymers referred to as alkyd resins. Polyesters usually have good thermal and oxidative stability (up to $200^{\circ} \mathrm{C}$ ), but have poor hydrolytic stability at elevated temperatures.

Hydrolytic degradation follows the typical ester hydrolysis mechanism, while thermal degradation involves a cyclic transition state to give the free acid and an olefin as depicted below for a six-membered ring (75):

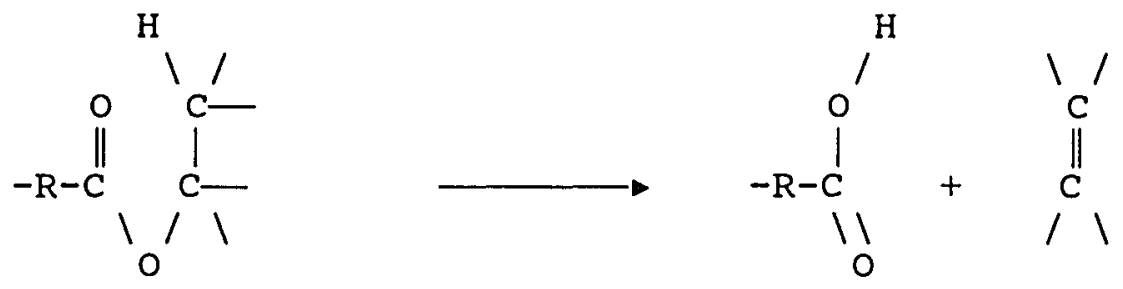

Replacement of some or all of the $\beta$ and $\gamma$ hydrogens in the alkyl portion by fluorine has been shown to increase thermal stability of various polyesters to over $450^{\circ} \mathrm{C}$ (76). 
TABLE XIII

MAJOR NUCLEOPHILES AND SUBSTRATES USED IN POLYESTER SYNTHESIS

\begin{tabular}{|c|c|c|}
\hline nucleophile & substrate & polymer structure \\
\hline$\stackrel{\mathrm{O}}{\mathrm{HO}-\mathrm{R}-\mathrm{C}-\mathrm{OH}}$ & (intramolecular) & $\stackrel{0}{\|} \|_{(-O-R-C-) n}$ \\
\hline $\mathrm{HO}-\mathrm{R}-\mathrm{OH}$ & $\stackrel{O}{\|}^{\prime}(\mathrm{C}-\mathrm{O}-\mathrm{H}) 2$ & $\stackrel{O}{\|} \stackrel{O}{\|} \stackrel{O}{\|}$ \\
\hline $\mathrm{HO}-\mathrm{R}-\mathrm{OH}$ & ${ }_{R^{\prime}} \stackrel{O}{\left.\|\left(C-O-R^{\prime}\right)^{\prime}\right) 2}$ & 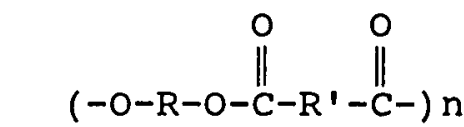 \\
\hline $\mathrm{HO}-\mathrm{R}-\mathrm{OH}$ & $\frac{O}{\|} R^{\prime}-O-C-O-R^{\prime}$ & $\stackrel{\stackrel{O}{\|}}{\stackrel{(-O-R-O-C-) n}{C}}$ \\
\hline $\mathrm{HO}-\mathrm{R}-\mathrm{OH}$ & $\mathrm{R}^{\prime}(\stackrel{\mathrm{O}-\mathrm{Cl}) 2}{\|}$ & 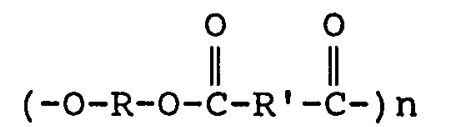 \\
\hline $\mathrm{NaO}-\mathrm{R}-\mathrm{ONa}$ & $\mathbb{R}^{\|}\left(C_{C-C l}\right) 2$ & 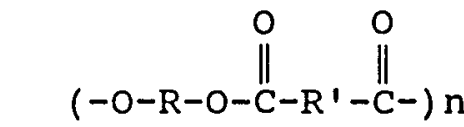 \\
\hline $\mathrm{HO}-\mathrm{R}-\mathrm{OH}$ & $\stackrel{O}{\|} \underset{R^{\prime} C-O-C-R^{\prime}}{O}$ & $\underset{(-O R O C O R \cdot C-) n}{O}$ \\
\hline
\end{tabular}

\section{Polyurethanes}

Applications of polyurethanes include coatings, flexible and rigid foams, elastomers, fibers, molded objects and as 
blends with other polymers. The three commercially important methods for preparing polyurethanes are reactions of; diisocyanates with diols, dichloroformates with diamines, and ester exchange reactions of urethanes and diols (77). These methods can be illustrated as shown below.

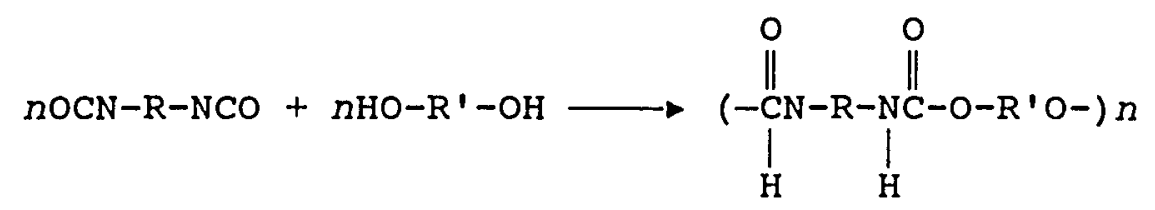

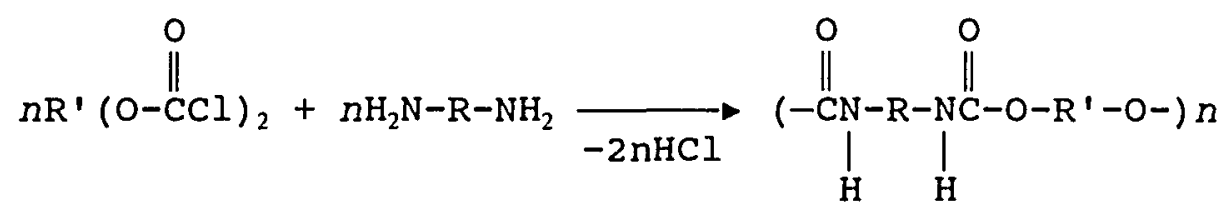

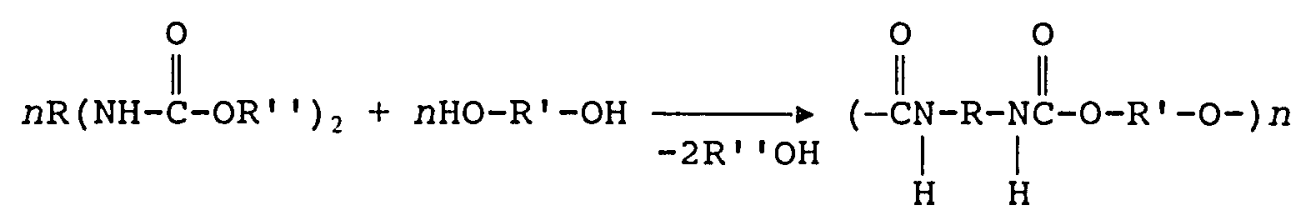

The latter two methods are simple formations of carboxylic acid derivatives and are driven to completion by removal of hydrogen chloride or alcohol using an acid acceptor or distillation, while the first method involves reaction of the isocyanate group.

The reactivity of the isocyanate group (78) is determined by the highly pronounced positive character of the central carbon atom which can be shown in various contributing resonance structures: 


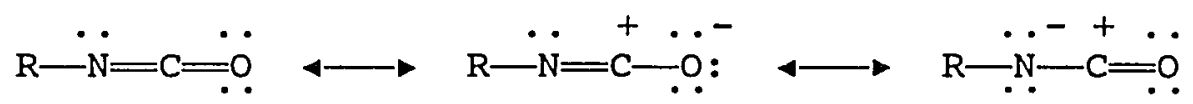

The reaction of alcohols with isocyanates is believed to proceed by initial nucleophilic attack by oxygen at the central carbon atom followed by deprotonation of the oxygen and protonation of the nitrogen:

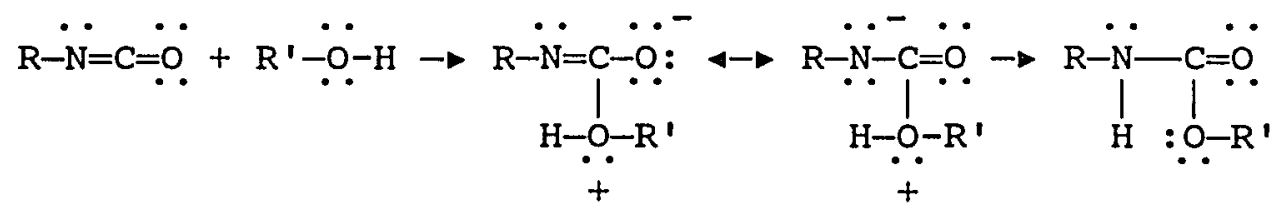

The trivial name, urethane, for ethyl carbamate $(\mathrm{R}=\mathrm{H}$, $\mathrm{R}^{\prime}=\mathrm{CH}_{2} \mathrm{CH}_{3}$ ) is applied to monomers and polymers possessing the above general structures.

The high reactivity of the isocyanate group can lead to various side reactions during the formation of urethanes and polyurethanes. Trace quantities of water can lead to the formation of unstable carbamic acids which decompose giving carbon dioxide and amines:

$\mathrm{R}-\mathrm{N}=\mathrm{C}=\mathrm{O}+\mathrm{H}_{2} \mathrm{O} \longrightarrow \stackrel{\mathrm{O}}{\|} \longrightarrow[\mathrm{R}-\mathrm{NH}-\mathrm{C}-\mathrm{OH}] \longrightarrow \mathrm{R}_{-} \mathrm{NH}_{2}+\mathrm{CO}_{2}$

Further reaction between the amine and the isocyanate results in urea derivatives:

$$
\mathrm{R}-\mathrm{N}=\mathrm{C}=\mathrm{O}+\mathrm{R}-\mathrm{NH}_{2} \longrightarrow \mathrm{R}-\mathrm{NH}-\mathrm{C}-\mathrm{NH}-\mathrm{R}
$$


The urethanes and urea derivatives formed in equations [34] and [36] are capable of reacting with the starting isocyanate as well, leading to formation of allophanates and biurets, respectively:<smiles>[R]NC(=O)N([R])C(=O)N[R7]</smiles><smiles>[R]NC(=O)N([R])C(=O)N[R]</smiles>

In the preparation of linear polyurethanes formed from diols and disocyanates these side reactions can lead to extensive branching and cross-linking.

\section{Polyacrylates}

The largest application of acrylic polymers is as window glazings. The polymer principally used for this purpose is poly (methyl methacrylate), sold under various trade names including Plexiglas. Other uses include coatings, adhesives, elastomers, films and in textile manufacturing $(80)$.

Acrylate ester are almost exclusively polymerized by free-radical processes. Free-radical polymerization can be brought about through thermal or photolytic decomposition of 
radical initiators such as azo compounds $(\mathrm{R}-\mathrm{N}=\mathrm{N}-\mathrm{R})$ or peroxides (R-O-O-R). A general reaction mechanism can be shown as below:

decomposition of initiator (I):

$$
\mathrm{I}-\mathrm{I} \longrightarrow 2 \mathrm{I} \text {. }
$$

initiation:<smiles>[R17]OC(=O)C([R])=C</smiles>

propagation:

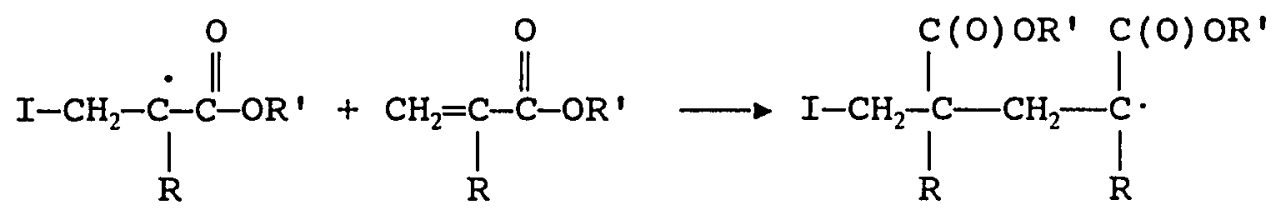

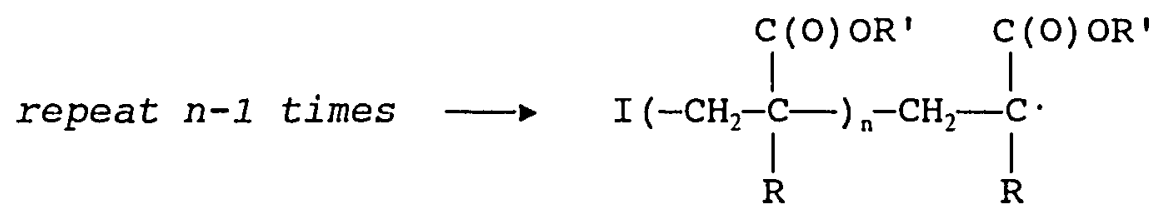

Termination of polymerization may occur by methods common to radical reactions; coupling two radicals, disproportionation of two radicals, or by chain-transfer (81).

The use of polyacrylates as films and coatings is a result of the general properties of acrylate polymers: high electrical resistance, the surface resistance of poly(methyl methacrylate) is on the order of $10^{-17}$ ohms; photochemical stability, most of the polymers absorb light at 
wavelengths well below $290 \mathrm{~nm}$; and thermal stability, most do not depolymerize when heated to decomposition. These properties and others vary depending on the nature of $R$ and $R^{\prime}$. Polymers possessing carboxylate groups have excellent anti-static properties and are readily dyable, 'while the presence of halogens result in a lower refractive index (81).

POLYMERIZATION REACTIONS INVOLVING $\mathrm{OCH}_{2} \mathrm{CHCH}_{2} \mathrm{OCF}_{2} \mathrm{CF}_{2} \mathrm{SO}_{2} \mathrm{~F}$ (XI)

Homopolymerization of the epoxide monomer

$\mathrm{OCH}_{2} \mathrm{CHCH}_{2} \mathrm{OCF}_{2} \mathrm{CF}_{2} \mathrm{SO}_{2} \mathrm{~F}(\mathrm{XI})$, and copolymerization with a commercially available diepoxide cross-linkinglagent was examined as a means of preparing epoxide polymers containing the $-\mathrm{OCF}_{2} \mathrm{CF}_{2} \mathrm{SO}_{2} \mathrm{~F}$ group. Polymerizations were performed under cationic conditions only in order to preserve the base labile $\mathrm{SO}_{2} \mathrm{~F} \mid$ group. The results obtained indicate the incorporation of the low surface energy and refractive index properties of the fluorinated alkyl sulfonyl fluoride group into these polymers. The sulfonate salt and sulfonic acid were also prepared from the homopolymer.

Cationic ring opening polymerization of $\mathrm{OCH}_{2} \mathrm{CHCH}_{2} \mathrm{OCF}_{2} \mathrm{CF}_{2} \mathrm{SO}_{2} \mathrm{~F},(\mathrm{XI})$, in the presence of mineral acids $\left(\mathrm{H}_{2} \mathrm{SO}_{4}\right.$ or $\left.\mathrm{H}_{3} \mathrm{PO}_{4}\right)$ a Lewis acid $\left(\mathrm{BF}_{3}\right)$ and a photoinitiated catalyst (UVI-6974, a commercially available triarylsulfonium hexafluoroantimonate) resulted in viscous liquid 
polymers in very good yields.

$$
\begin{aligned}
& n \mathrm{OCH}_{2} \mathrm{CHCH}_{2} \mathrm{OCF}_{2} \mathrm{CF}_{2} \mathrm{SO}_{2} \mathrm{~F} \underset{\mathrm{UVI}-6974, \mathrm{hV}}{\mathrm{acid} \text { catalyst }} \text { or }\left[\mathrm{CH}_{2} \mathrm{CHO}_{\mathrm{A}}\right. \\
& \mathrm{CH}_{2} \mathrm{OCF}_{2} \mathrm{CF}_{2} \mathrm{SO}_{2} \mathrm{~F} \\
& \text { (XVII) }
\end{aligned}
$$

The reaction between the homopolymer (XVII) and sodium hydroxide resulted in the formation of a polymeric sodium sulfonate salt:

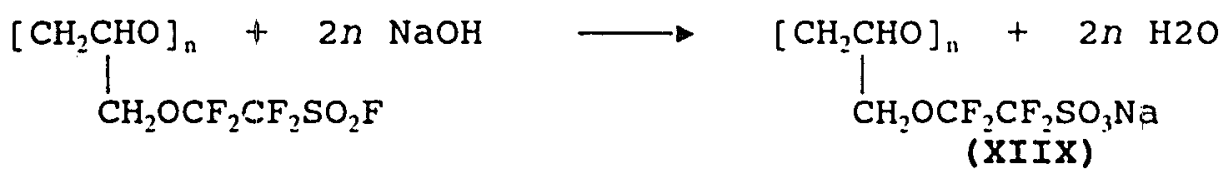

from which the acid was obtained by passing the salt through a strong cation-exchange column:

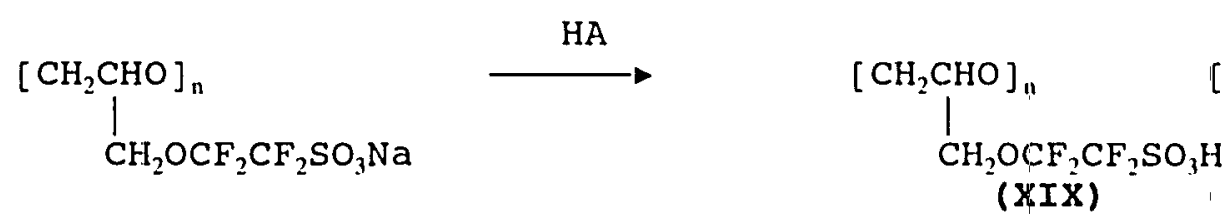

The ${ }^{1} \mathrm{H}$ and ${ }^{19} \mathrm{~F}$ NMR spectra of (XVII), (XIIX) and (XIX) consisted of broad unresolved resonances (TABLE XIV). In the ${ }^{1} \mathrm{H}$ spectra, resonances occurred near in the regions of $4.3-4.0$ and $3.8-3.6 \mathrm{ppm}$ downfield from TMS with linewidths 1 of about $40 \mathrm{Mhz}$. This agrees closely with derivatives of epichlorohydrin polymers $\left[\mathrm{CH}_{2} \mathrm{CH}\left(\mathrm{CH}_{2} \mathrm{Cl}\right)\right]_{n}$ where the polymer chain proton resonances appear as two broad unresolved resonances at about 4 to $3.5 \mathrm{ppm}(82) \cdot$ The acidic proton of $(\mathrm{XIX})$ appeared at $9.7 \mathrm{ppm}$ in $\mathrm{CD} 3 \mathrm{CN}$. In the 
${ }^{19} \mathrm{~F}$ NMR spectra, the $-O \mathrm{C}_{\mathrm{F}} 2$ - chemical shift values in all three compounds were near $-85.6 \mathrm{ppm}$, while the $-\mathrm{CF}_{2} \mathrm{~S}$ values ranged from $-112.1 \mathrm{ppm}$ for (XVII) to -118.3 and $-119.2 \mathrm{ppm}$ for (XIIX) and (XIX). The increased shielding of these fluorines in (XIIX) and (XIX) is consistent with the anionic nature of the salt and acid. The $\mathrm{SO}_{2} \mathrm{~F}$ resonance for (XIIX) occurred at $43.5 \mathrm{ppm}$.

Characteristic epoxide absorbances (67) present in the infrared spectrum of $(X I):(3069, \mathrm{C}-\mathrm{H}$ stretch; 1270, ring breathing; and 950, asymmetrical ring stretch) were absent in the polymer (XVII), salt (XIIX) and acid (XIX). The strong $\mathrm{SO}_{2} \mathrm{~F}$ asymmetric and symmetric stretches at 1455 and 1244 and a strong SO2F band at $815 \mathrm{~cm}^{-1}$ were observed for (XI) and were absent in (XIIX) and (XIX), while the corresponding frequencies for the $\mathrm{SO}_{3}$ group appeared in the regions of 1240 and $1098 \mathrm{~cm}^{-1}$ in (XIIX) and (XIX). Also present in the acid (XIX) were bands at 3191 and $1722 \mathrm{~cm}^{-1}$ corresponding to the $\mathrm{SO}_{3} \mathrm{H}$ group of the acid. 
TABLE XIV

${ }^{1} \mathrm{H}$ AND ${ }^{19} \mathrm{~F}$ NMR DATA FOR EPOXIDE HOMOPOLYMER [-OCH2CH (CH2OCF2CF2SO2F) - ] n (XVII) POLYMERIC SULFONATE SALT $[-\mathrm{OCH} 2 \mathrm{CH}(\mathrm{CH} 2 \mathrm{OCF} 2 \mathrm{CF} 2 \mathrm{SO} 3 \mathrm{Na})-] n$ (XIIX) AND POLYMERIC SULFONIC ACID [-OCH2CH (CH2OCF2CF2SO3Na)-]n (XIX)*

\begin{tabular}{|c|c|c|c|c|}
\hline $\mathrm{OCH} 2 \mathrm{CHCH} 2 \mathrm{O}$ & OCF2 & CF2S & $\mathrm{SO} 2 \mathrm{~F}$ & $\mathrm{SO} 3 \mathrm{H}$ \\
\hline \multicolumn{5}{|c|}{$[-\mathrm{OCH} 2 \mathrm{CH}(\mathrm{CH} 2 \mathrm{OCF} 2 \mathrm{CF} 2 \mathrm{SO} 2 \mathrm{~F})-] n$ (XVII) } \\
\hline $\begin{array}{c}4.2 \text { and } 3.7 \\
\text { unresolved } \\
\text { (broad) }\end{array}$ & $\begin{array}{c}-85.6 \\
\text { (broad) }\end{array}$ & $\begin{array}{l}-112.1 \\
\text { (broad) }\end{array}$ & $\begin{array}{c}43.5 \\
\text { (broad) }\end{array}$ & -- \\
\hline \multicolumn{5}{|c|}{$[-\mathrm{OCH} 2 \mathrm{CH}(\mathrm{CH} 2 \mathrm{OCF} 2 \mathrm{CF} 2 \mathrm{SO} 3 \mathrm{Na})-] n(\mathrm{XIIX})$} \\
\hline $\begin{array}{c}4.3 \text { and } 3.8 \\
\text { unresolved } \\
\text { (broad) }\end{array}$ & $\begin{array}{c}-85.7 \\
\text { (broad) }\end{array}$ & $\begin{array}{l}-118.3 \\
\text { (broad) }\end{array}$ & -- & -- \\
\hline \multicolumn{5}{|c|}{$[-\mathrm{OCH} 2 \mathrm{CH}(\mathrm{CH} 2 \mathrm{OCF} 2 \mathrm{CF} 2 \mathrm{SO} 3 \mathrm{Na})-] n \quad(\mathrm{XIX})$} \\
\hline $\begin{array}{c}4.0 \text { and } 3.6 \\
\text { unresolved } \\
\text { (broad) }\end{array}$ & $\begin{array}{c}-85.6 \\
\text { (broad) }\end{array}$ & $\begin{array}{l}-119.2 \\
\text { (broad) }\end{array}$ & -- & 9.7 \\
\hline
\end{tabular}

"Chemical shifts in ppm; coupling constants in $\mathrm{Hz}$.

Photoinitiated catalyzed copolymerization of epoxide (XI) with Cyracure UVR-6110, a commercially available cycloaliphatic diepoxide, resulted in copolymeric film coatings which were formed in situ:

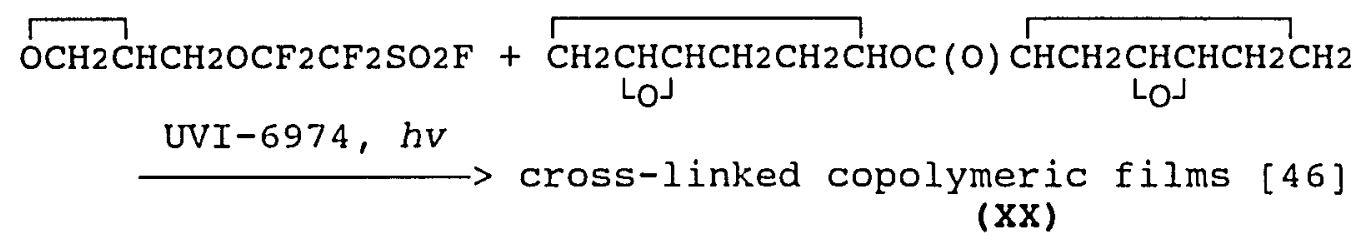


Polymerization of comonomers with sites of differing hydrophobicity often leads to phase separation (83). The results in TABLE XV indicate that phase separation may be occurring in the copolymeric films.

TABLE XV

OPTICAL CLARITY AND CONTACT OF DISTILLED WATER FOR POLYMERIC FILMS (XX) COMPOSED OF

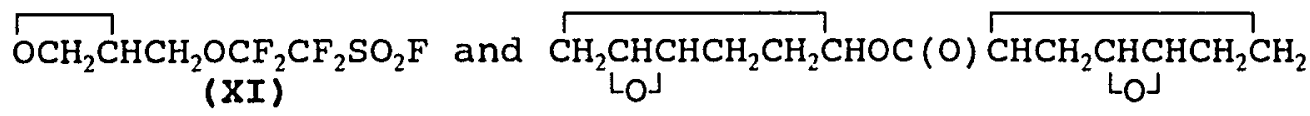

\begin{tabular}{lllllll}
\hline Film sample & A & B & C & D & E & F \\
\hline $\begin{array}{l}\text { Composition } \\
\text { wt\% of (XI) }\end{array}$ & 67 & 60 & 50 & 33 & 17 & 0 \\
$\begin{array}{l}\text { Contact } \\
\text { anglea }\end{array}$ & $66(2)$ & $65(1)$ & $66(1)$ & $65(2)$ & $63(1)$ & $41(0)$ \\
$\begin{array}{l}\text { optical } \\
\text { clarity }\end{array}$ & opaque opaque slightly clear clear & clear \\
opaque
\end{tabular}

${ }^{a}$ Average of three measurements(std.dev.)

Films $\mathbf{D}$ and $E$, containing lower proportions of (XI) are transparent, indicating that no major phase separation has occurred between the fluorinated and cycloaliphatic components. Films $\mathbf{A}$ and $\mathbf{B}$, on the other hand, are opaque with film $\mathbf{c}$ being only slightly opaque. Analysis of the contact angle measurements show that all the copolymeric films possess lower surface energies than film $\mathbf{F}$ which contains no fluorinated copolymer. A possible explanation is that in films $\mathbf{D}$ and $\mathbf{E}$ polymerization leads to a single 
phase in the bulk of the product and at the surface the fluorinated groups are oriented along the air interface. In films $A$ and $B$ phase separation is occurring in the bulk, resulting in significant loss of optical clarity.

\section{POLYMERIZATION REACTIONS INVOLVING $\mathrm{HOCH} 2 \mathrm{CH}(\mathrm{OH}) \mathrm{CH} 2 \mathrm{OCF} 2 \mathrm{CF} 2 \mathrm{SO} 2 \mathrm{~F} \quad(\mathrm{XV})$}

The diol $\mathrm{HOCH}_{2} \mathrm{CH}(\mathrm{OH}) \mathrm{CH}_{2} \mathrm{OCF}_{2} \mathrm{CF}_{2} \mathrm{SO}_{2} \mathrm{~F}$ (XV) was a valuable intermediate in the preparation of polymeric materials containing the $-\mathrm{OCF}_{2} \mathrm{CF}_{2} \mathrm{SO}_{2} \mathrm{~F}$ grouping. The condensation polymerization with hexafluoroglutaric anhydride as a bulk mixture resulted in a viscous liquid polyester:

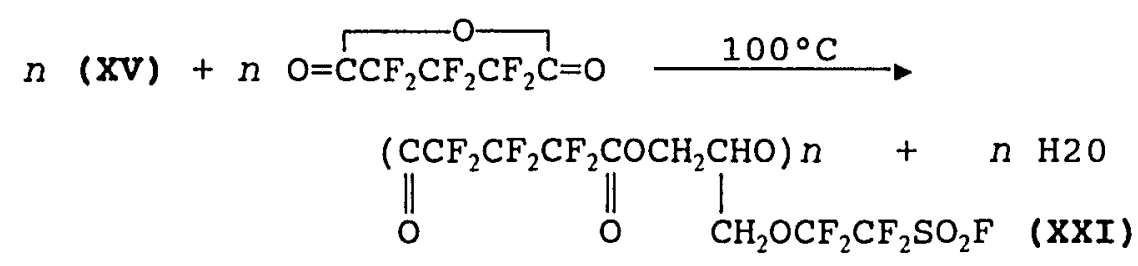

The product showed two broad unresolved 'H NMR resonances in $\mathrm{CD}_{3} \mathrm{CN}$, with chemical shift values of 5.5 and $5.3 \mathrm{ppm}$ (TABLE $X V I$ ). In the ${ }^{19} \mathrm{~F}$ NMR spectrum (TABLE XVI) a pentet at $-126.6 \mathrm{ppm}$ was found for the internal $\mathrm{CF}_{2}$ group in the polymer backbone, while all other resonances were broad and unresolved. The infrared spectrum showed a strong carbonyl band at $1792 \mathrm{~cm}^{-1}$ and agrees with those reported for fluorocarbon esters $(84,85)$. 
TABLE XVI

${ }^{1} \mathrm{H}$ AND ${ }^{19} \mathrm{~F}$ NMR DATA FOR POLYESTER

$[-\mathrm{OC}(\mathrm{O}) \mathrm{CF} 2 \mathrm{CF} 2 \mathrm{CF} 2 \mathrm{C}(\mathrm{O}) \mathrm{OCH} 2 \mathrm{CH} 2 \mathrm{CH} 2 \mathrm{OCF} 2 \mathrm{CF} 2 \mathrm{SO} 2 \mathrm{~F})-] \Omega(\mathrm{XXI})^{*}$

\begin{tabular}{|c|c|c|c|c|}
\hline$O C(O) C F 2^{a} C F 2^{b} C F 2^{a} C(0) O$ & $\mathrm{CH} 2 \mathrm{CHCH} 2 \mathrm{O}$ & $\mathrm{CF} 2$ & CF2S & $\mathrm{SO} 2 \mathrm{~F}$ \\
\hline $\begin{array}{l}F^{a}-121.3 \\
(\text { broad }) \\
F^{b}-126.6 \quad(p) \\
J F^{a}=16.0\end{array}$ & $\begin{array}{l}5.5-5.3 \\
\text { (broad) } \\
\text { unresolved }\end{array}$ & $\begin{array}{l}-86.8 \\
\text { (broad) }\end{array}$ & $\begin{array}{c}-114.3 \\
\text { (broad) }\end{array}$ & $\begin{array}{l}43.0 \\
\text { (broad) }\end{array}$ \\
\hline
\end{tabular}

"Chemical shifts in ppm; coupling constants in $\mathrm{Hz}$.

Solid polymeric materials were formed from the thermal reaction of diol (XV) with 1,6-diisocyanohexane. This reaction was performed in solution to give a solid bulk product, and as a thin film yielding a solid polymeric film coating formed in situ on a glass substrate. While the product formed from a direct one-to-one reaction would have the following structure:

$n$<smiles>O=C=NCCCCCCN=C=NCOCC(O)CO</smiles>

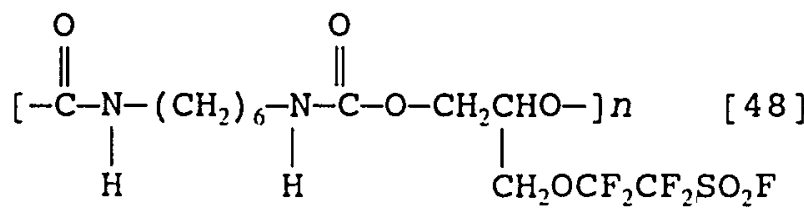

based on the elemental analysis an approximate composition includes one diol to six disocyanate molecules. This composition can be possibly explained by the reaction of the 
amide sites in the product with other isocyanate groups as illustrated below for one site:

$\left.\left.\left.\right|_{\mathrm{H}} ^{\mathrm{O}}\right|_{\mathrm{H}} ^{\mathrm{C}}-\mathrm{N}-\left(\mathrm{CH}_{2}\right)_{6}-\mathrm{N}-\mathrm{C}-\mathrm{O}-\left.\mathrm{CH}_{2}\right|_{\mathrm{CH}_{2} \mathrm{OCF}_{2} \mathrm{CF}_{2} \mathrm{SO}_{2} \mathrm{~F}} ^{\mathrm{O}}\right] \mathrm{N}:+\mathrm{O}=\mathrm{C}=\mathrm{N}-\left(\mathrm{CH}_{2}\right)_{6}-\mathrm{N}=\mathrm{C}=\mathrm{O} \longrightarrow$

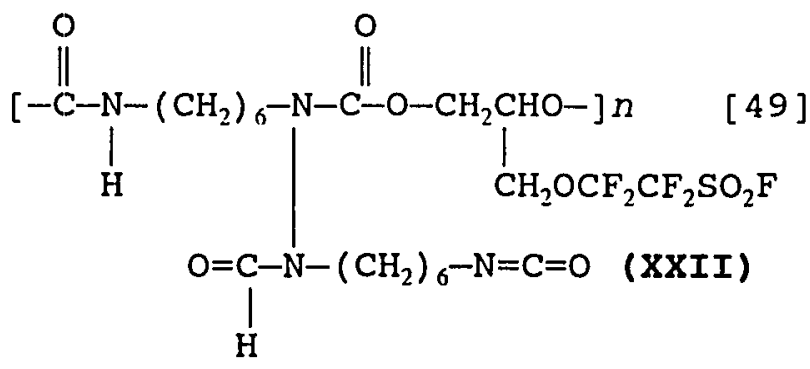

Further reactions of this type would lead to extensive cross-linking, possibly explaining the formation of the solid polymeric products.

The urethane polymer (XXII) was found to be very tough and flexible, insoluble in alcohol, acetone, water, acetonitrile, hexane, hexafluoropropanol, concentrated ammonia and 1 molar potassium hydroxide. It was swelled by trifluoroacetic acid and appeared to dissolve in concentrated hydrochloric or concentrated sulfuric acid. The infrared spectrum or the product, after extraction with acetone, contained no bands attributable to the starting diisocyanate reactant. The bands at 3339,1714 and 1532 and $765 \mathrm{~cm}^{-1}$ can be assigned to the $\mathrm{N}-\mathrm{H}$ stretching, carbonyl stretching, and $\left(\mathrm{CH}_{2}\right)_{6}$ rocking motions, respectively (65). 
The strong $\mathrm{SO}_{2}$ asymmetric and symmetric stretchings and $\mathrm{S}-\mathrm{F}$ band were observed at 1445,1250 and $811 \mathrm{~cm}^{-1}$, respectively, while the carbon-fluorine bands were found at 1145 and $1068 \mathrm{~cm}^{-1}$.

POLYMERIZATION OF $\mathrm{CH} 2=\mathrm{CHC}(\mathrm{O}) \mathrm{CH} 2 \mathrm{CH} 2 \mathrm{CF} 2 \mathrm{CF} 2 \mathrm{OCF} 2 \mathrm{CF} 2 \mathrm{SO} 2 \mathrm{~F}$ (XVI)

Free-radical polymerization of the acrylate ester $\mathrm{CH}_{2}=\mathrm{CHC}(\mathrm{O}) \mathrm{CH}_{2} \mathrm{CH}_{2} \mathrm{CF}_{2} \mathrm{CF}_{2} \mathrm{OCF}_{2} \mathrm{CF}_{2} \mathrm{SO}_{2} \mathrm{~F}$ (XVI) was investigated as a means of preparing a novel class of fluoroalkyl acrylate polymers containing the sulfonyl fluoride group. Polymerization of the monomer was successfully performed in solution, in bulk and as a film formed in situ using azo(bis) isobutyronitrile (AIBN) as a radical initiator.

Solution polymerization was thermally initiated in refluxing acetone while bulk and film-forming polymerizations were achieved using photoinitiation:

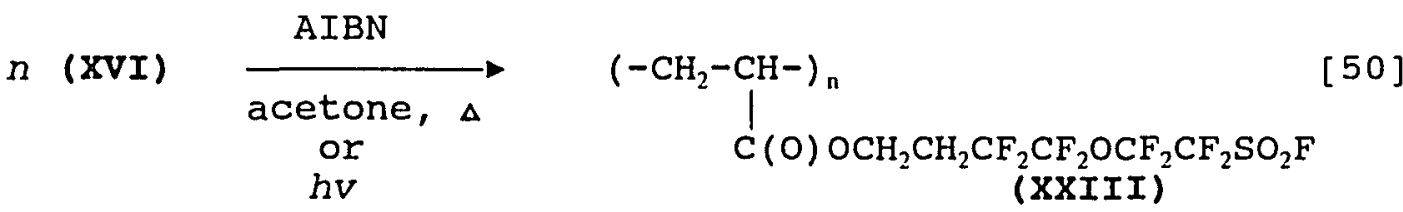

Yields of all polymerizations were in excess of $95 \%$ resulting in viscous liquids or a tacky film.

The ${ }^{1} H$ NMR spectrum of the product is consistent with the polymerized structure. Olefinic protons in the $6.2-7.0 \mathrm{ppm}$ region, present in the monomer, were not observed. Instead, a new broad unresolved resonance at $2.5 \mathrm{ppm}$, indicative of 
aliphatic protons, was present. Resonances for the other protons in the structure were broad and unresolved as well (TABLE XVII). The chemical shifts in the ${ }^{19} \mathrm{~F}$ NMR spectrum were essentially unchanged from those in the monomer. As in the ${ }^{1} \mathrm{H}$ spectrum, the signals were broad and unresolved with the exception of the $\mathrm{CH}_{2} \mathrm{CF}_{2}$ fluorines for which a triplet splitting pattern was observed (TABLE XVII). The bands characteristic of olefinic carbon-hydrogen and carboncarbon stretching (3044 and $1639 \mathrm{~cm}^{-1}$ ) present in the infrared spectrum of the monomer were not present in the spectra of the polymers, supporting the proposed structure. Also absent was the olefinic $\mathrm{CH}_{2}$ scissoring band seen at $1639 \mathrm{~cm}^{-1}$ in the spectrum of the monomer. While no new features could be identified in the spectra of the polymers, due to the presence of many strong bands already present in the aliphatic carbon-carbon region, the above spectral data are consistent with the structure. 
TABLE XVII

${ }^{1} \mathrm{H}$ and ${ }^{19} \mathrm{~F}$ NMR data for $[(-\mathrm{CH} 2-\mathrm{CH}-) \mathrm{C}(\mathrm{O}) \mathrm{OCH} 2 \mathrm{CH} 2 \mathrm{CF} 2 \mathrm{CF} 2 \mathrm{OCF} 2 \mathrm{CF} 2 \mathrm{SO} 2 \mathrm{~F}] \mathrm{n}$ (XXIII)

\begin{tabular}{cccccccc}
\hline$-\mathrm{CH}_{2}{ }^{\mathrm{a}}-\mathrm{CH}^{\mathrm{b}}-$ & $\mathrm{OCH}_{2}{ }^{\mathrm{c}}$ & $\mathrm{CH} 2^{\mathrm{d}}$ & $\mathrm{CF} 2^{\mathrm{e}}$ & $\mathrm{CF} 2^{\mathrm{fO}}$ & $\mathrm{CF}^{\mathrm{g}}$ & $\mathrm{CF} 2^{\mathrm{h} S}$ & $\mathrm{SO} 2 \mathrm{~F}^{\mathrm{i}}$ \\
\hline 2.5 & 4.5 & 1.8 & $\begin{array}{l}-118.0(t) \\
J F^{\mathrm{c}}-\mathrm{H}^{\mathrm{d}}=18.3\end{array}$ & -88.2 & -83.0 & -113.2 & 45.8
\end{tabular}

"Chemical shifts in ppm; coupling constants in $\mathrm{Hz}$. " ${ }^{A} \mathrm{ll}$ other resonances were broad and unresolved. 
EXPERIMENTAL

\section{$\mathrm{C} 1 \mathrm{CH}_{2} \mathrm{CH}(\mathrm{OH}) \mathrm{CH}_{2} \mathrm{OCF} 2 \mathrm{CF}_{2} \mathrm{SO}_{2} \mathrm{~F}$ (XII)}

To a $10 \mathrm{ml}$ round bottom flask containing a Teflon coated stirring bar and fitted with a reflux condenser and calcium chloride drying tube was added 5.66 mol of $\mathrm{OCH}_{2} \mathrm{CHCH}_{2} \mathrm{OCF}_{2} \mathrm{CF}_{2} \mathrm{SO}_{2} \mathrm{~F}, 1.10 \mathrm{~g}$ of $12 \mathrm{M}$ hydrochloric acid and 5 ml of diethyl ether. The contents were heated to reflux with vigorous stirring for $24 \mathrm{~h}$. 1 After addition of $5 \mathrm{ml}$ of water the resulting oily lower phase was separated, washed with water, dried over sodium sulfate then filtered. Distillation at 8 torr resulted in $4.52 \mathrm{mmol}$ ( $80 \%$ yield) of product boiling at $84-86^{\circ} \mathrm{C}$.

The infrared spectrum had the following bands $\left(\mathrm{cm}^{-1}\right)$ :

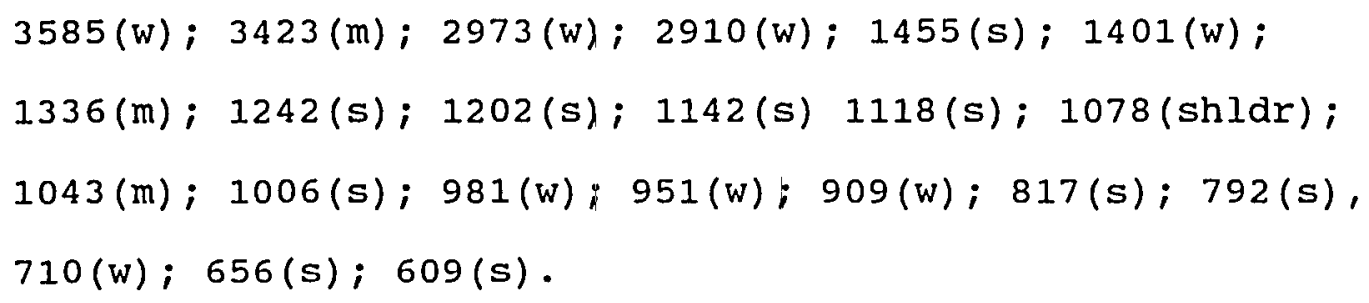

${ }^{1} \mathrm{H}$ NMR data $\left(\mathrm{CDCl}_{3}\right.$, internal TMS): Chemical shifts and coupling constants in TABLE IIX; relative integration area $\mathrm{ClCH}_{2}(1.9), \mathrm{CH}(\mathrm{OH})(1.0), \mathrm{CH}_{2} \mathrm{O}(2.0)$.

${ }^{19} \mathrm{~F}$ NMR data $\left(\mathrm{CDCl}_{3}\right.$, internal TMS): Chemical shifts and coupling constants in TABLE IX; relative integration area $\mathrm{OCF}_{2}(2.1), \mathrm{CF}_{2} \mathrm{~S}(2.1), \mathrm{SO}_{2} \mathrm{~F}(1.0) !$

${ }^{13} \mathrm{C}$ NMR data $\left(\mathrm{CDCl}_{3}\right.$, internal TMS): Chemical shifts and coupling constants in TABLE $x$. 
Mass spectral data (m/e, species): $\mathrm{EI}^{+} 243\left(\mathrm{M}-\mathrm{CH}_{2} \mathrm{Cl}\right)$; $133\left(\mathrm{CF}_{2} \mathrm{SO}_{2} \mathrm{~F}\right) ; 83\left(\mathrm{SO}_{2} \mathrm{~F}\right) ; 81 / 79\left(\mathrm{ClCH}_{2} \mathrm{CHOH}\right) ; 51 / 49\left(\mathrm{CH}_{2} \mathrm{Cl}\right)$.

Anal. Calcd. for $\mathrm{C}_{5} \mathrm{H}_{6} \mathrm{~F}_{5} \mathrm{SClO}_{4}: \mathrm{C}, 20.52 ; \mathrm{H}, 2.07 ; \mathrm{S}, 10.69$; Cl, $12.12 \%$. Found: C, $20.49 ; \mathrm{H}, 2.11 ; \mathrm{S}, 10.89 ; \mathrm{Cl}, 12.19 \%$.

$\mathrm{HOCH} 2 \mathrm{CH}(\mathrm{OCH} 2 \mathrm{C} 6 \mathrm{H} 5) \mathrm{CH}_{2} \mathrm{OCF} 2 \mathrm{CF} 2 \mathrm{SO} 2 \mathrm{~F}$ (XIV) and $\mathrm{C} 6 \mathrm{H}_{5} \mathrm{CH} 2 \mathrm{OCH} 2 \mathrm{CH}(\mathrm{OH}) \mathrm{CH}_{2} \mathrm{OCF} 2 \mathrm{CF}_{2} \mathrm{SO}_{2} \mathrm{~F}(\mathrm{XV})$

To a $15 \mathrm{ml}$ round bottom flask equipped with a Teflon coated stirring bar, reflux condenser and a calcium chloride drying tube was added $7.70 \mathrm{mmol}$ of $\mathrm{OCH}_{2} \mathrm{CHCH}_{2} \mathrm{OCF}_{2} \mathrm{CF}_{2} \mathrm{SO}_{2} \mathrm{~F}, 15.5$ mmol of freshly distilled benzyl alcohol, $8 \mathrm{ml}$ of diethyl ether and three drops of concentrated sulfuric acid. After heating to reflux with vigorous stirring for $24 \mathrm{~h}$ the diethyl ether was removed by distillation at atmospheric pressure. The pot residue was washed five times with $25 \mathrm{ml}$ of water, dried over sodium sulfate and filtered. Distillation at $0.5 \mathrm{~mm} \mathrm{Hg}$ pressure and $138-140^{\circ} \mathrm{C}$ resulted in $2.94 \mathrm{mmol}$ (38\% yield) of a mixture consisting of $55 \%$ (XIII) and $45 \%$ (XIV) as determined by GC-MS and ${ }^{1} \mathrm{H}-\mathrm{NMR}$. No further attempts were made to separate the two components.

The infrared spectrum of the mixture had the following bands $\left(\mathrm{cm}^{-1}\right): 3416(\mathrm{~m}) ; 3093(\mathrm{w}) ; 3064(\mathrm{w}) ; 3036(\mathrm{w}) ; 2917(\mathrm{w})$; $2868(\mathrm{w}) ; 1955(\mathrm{vw}) ； 1836(\mathrm{Vw}) ； 1810(\mathrm{Vw}) ; 1724(\mathrm{Vw}) ; 1495(\mathrm{w})$; $1455(\mathrm{~s}) ； 1391(\mathrm{~m}) ； 1363(\mathrm{~m}) ； 1335(\mathrm{~m}) ； 1243(\mathrm{~s}) ； 1202(\mathrm{~s})$; $1138(\mathrm{~s}) ; 1117(\mathrm{~s}) ； 1005(\mathrm{~m}) ; 948(\mathrm{w}) ; 913(\mathrm{w}) ; 814(\mathrm{~m}) ; 788(\mathrm{~m})$; $745(\mathrm{~m}) ; 700(\mathrm{~m}) ; 654(\mathrm{~m}) ; 609(\mathrm{~m})$. 
${ }^{1} \mathrm{H}$ NMR data for mixture $\left(\mathrm{CD}_{3} \mathrm{CN}\right.$, internal TMS): Chemical shifts and coupling constants in TABLE IIX; relative integration area $\mathrm{C}_{6} \mathrm{H}_{5}$ (XIII) \& (XIV) (10.0), $\mathrm{C}_{6} \mathrm{H}_{5} \mathrm{C}_{2}$ (XIII)\&(XIV) (4.2), $\mathrm{HOCH}_{2}$ (XIII) \& $\mathrm{C}_{6} \mathrm{H}_{5} \mathrm{CH}_{2} \mathrm{OCH}_{2}$ (XIV) (4.3), $\mathrm{CH}$ (XIII) (1.1), $\mathrm{CH}$ (XIV) (1.0), $\mathrm{CH}_{2} \mathrm{OCF}_{2}$ (XIII)\&(XIV) (4.1), OH $(X I I I) \&(X I V)(1.8)$

${ }^{19} \mathrm{~F}$ NMR data $\left(\mathrm{CD}_{3} \mathrm{CN}\right.$, internal TMS $)$ Chemical shifts and coupling constants in TABLE IX: relative integration area $\mathrm{OCF}_{2}$ (XIII)\&(XIV) $2.1, \mathrm{CF}_{2} \mathrm{~S}$ (XIII)\&(XIV) (2.0), $\mathrm{SO}_{2} \mathrm{~F}$ (XIII) $\&(X I V)(1.0)$

${ }^{13} \mathrm{C}$ NMR data $\left(\mathrm{CD}_{3} \mathrm{CN}\right.$, internal TMS): Chemical shifts and coupling constants in TABLE $X$.

Mass spectral data (m/e, species): $\mathrm{EI}^{+} 364$ (molecular ion); $243\left(\mathrm{M}_{-} \mathrm{C}_{6} \mathrm{H}_{5} \mathrm{CH}_{2} \mathrm{OCH}_{2}\right) ; 151\left(\mathrm{C}_{6} \mathrm{H}_{5} \mathrm{CH}_{2} \mathrm{OCH} \mathrm{CHOH}_{2} \mathrm{CHO}\right) 133\left(\mathrm{CF}_{2} \mathrm{SO}_{2} \mathrm{~F}\right)$; $107\left(\mathrm{C}_{6} \mathrm{H}_{5} \mathrm{CH}_{2} \mathrm{O}\right) ; 83\left(\mathrm{SO}_{2} \mathrm{~F}\right) ; 77\left(\mathrm{C}_{6} \mathrm{H}_{5}\right) ; 65\left(\mathrm{C}_{5} \mathrm{H}_{5}\right) ; 51\left(\mathrm{C}_{4} \mathrm{H}_{3}\right) ; 39$ $\left(\mathrm{C}_{3} \mathrm{H}_{3}\right) ; 31\left(\mathrm{CH}_{2} \mathrm{OH}\right)$.

Anal. Calcd. for $\mathrm{C}_{12} \mathrm{H}_{13} \mathrm{~F}_{5} \mathrm{SO}_{4}: \mathrm{C}, 39.57 ; \mathrm{H}, 3.60 ; \mathrm{F}, 26.1$; S, $8.80 \%$. Found: C, $42.64 ; \mathrm{H}, 4.16 ; \mathrm{F}, 24.1 ; \mathrm{S}, 8.20 \%$.

\section{$\mathrm{HOCH} 2 \mathrm{CH}(\mathrm{OH}) \mathrm{CH} 2 \mathrm{OCF} 2 \mathrm{CF} 2 \mathrm{SO} 2 \mathrm{~F}$ (XV) with $\mathrm{H}_{2} \mathrm{SO} 4$}

Into a $25 \mathrm{ml}$ round bottom flask containing a Teflon coated stirring bar and fitted with a reflux condenser topped with a calcium chloride drying tube was added 10.2 mmol of epoxide $\mathrm{OCH}_{2} \mathrm{CHCH}_{2} \mathrm{OCF}_{2} \mathrm{CF}_{2} \mathrm{SO}_{2} \mathrm{~F}, 2.5 \mathrm{ml}$ of water containing $0.1 \mathrm{~g}$ of $95 \%$ sulfuric acid, and $15 \mathrm{ml}$ of tetrahydrofuran. After refluxing for five hours the flask 
was cooled and $25 \mathrm{ml}$ of water added. The lower organic phase was removed and washed five times with $10 \mathrm{ml}$ of water, dried over sodium sulfate and filtered. Distillation at 0.5 torr resulted in $3.65 \mathrm{mmol}$ ( $36 \%$ yield) of product at 100$101^{\circ} \mathrm{C}$.

\section{with Nafion}

Using a similar apparatus, $20 \mathrm{ml}$ of distilled tetrahydrofuran containing $13.7 \mathrm{mmol}$ of $\mathrm{OCH}_{2} \mathrm{CHCH}_{2} \mathrm{OCF}_{2} \mathrm{CF}_{2} \mathrm{SO}^{2} \mathrm{~F}, 2 \mathrm{~g}$ of Nafion NR5O 10-35 mesh beads in the acidic form and $2 \mathrm{ml}$ of water were stirred at room temperature for $24 \mathrm{~h}$. The solution was filtered and the solvent removed by distillation at atmospheric pressure. The product $(7.81 \mathrm{mmol}, 57 \%$ yield), was isolated by distillation at 0.5 torr and $100-101^{\circ} \mathrm{C}$.

The infrared spectrum had the following bands $\left(\mathrm{cm}^{-1}\right)$ : $3381(\mathrm{~m}) ； 2966(\mathrm{w}) ； 2946(\mathrm{w}) ； 2896(\mathrm{w}) ； 1456(\mathrm{~s}) ； 1404(\mathrm{w}) ;$ $1335(\mathrm{~m}) ； 1244(\mathrm{~m}) ； 1202(\mathrm{~m}) ； 1145(\mathrm{~m}) ; 1117(\mathrm{~s}) ； 1047(\mathrm{~m})$; $1005(\mathrm{~m}) ; 944(\mathrm{w}) ; \quad 933(\mathrm{w}) ; 881(\mathrm{w}) ; 814(\mathrm{~m}) ; 791(\mathrm{~m}) ; 657(\mathrm{~m}) ;$ $609(s) ; 523(s)$.

${ }^{1} \mathrm{H}$ NMR data $\left(\mathrm{CDCl}_{3}\right.$, internal TMS): Chemical shifts and coupling constants in TABLE IIX; relative integration area $\mathrm{HO}(2.0), \mathrm{HOCH}_{2}(1.8), \mathrm{CH}(0.9), \mathrm{CH}_{2} \mathrm{OCF}_{2}(1.9)$.

${ }^{19} \mathrm{~F}$ NMR data $\left(\mathrm{CDCl}_{3}\right.$, internal $\left.\mathrm{CCl}_{3} \mathrm{~F}\right)$ : Chemical shifts and coupling constants in Table IX; relative integration area $\mathrm{OCF}_{2}(2.1), \mathrm{CF}_{2} \mathrm{~S}(2.1), \mathrm{SO}_{2} \mathrm{~F}(1.0)$.

${ }^{13} \mathrm{C}$ NMR data $\left(\mathrm{CDCl}_{3}\right.$, internal TMS): Chemical shifts and 
coupling constants in Table $x$.

Mass spectral data (m/e, species): $\mathrm{EI}^{+} 243\left(\mathrm{M}-\mathrm{CH}_{2} \mathrm{OH}\right)$;

$133\left(\mathrm{CF}_{2} \mathrm{SO}_{2} \mathrm{~F}\right) ; 100\left(\mathrm{CF}_{2} \mathrm{CF}_{2}\right) ; 97\left(\mathrm{C}_{2} \mathrm{~F}_{3} \mathrm{O}\right) ; 83\left(\mathrm{SO}_{2} \mathrm{~F}\right) ; 61$

$\left(\mathrm{CH}_{2}(\mathrm{OH}) \mathrm{CH}(\mathrm{OH})\right) ; 31\left(\mathrm{CH}_{2} \mathrm{OH}\right)$.

Analysis: Calculated for $\mathrm{C}_{5} \mathrm{H}_{7} \mathrm{~F}_{5} \mathrm{SO}_{5}: \mathrm{C}, 21.91 ; \mathrm{H}, 2.56 ; \mathrm{F}$, $34.6 ; \mathrm{S}, 11.69 \%$. Found: C, $22.21 ; \mathrm{H}, 2.70 ; \mathrm{F}, 34.2 ; \mathrm{S}$, $11.42 \%$

ACRYLATE ESTER $\mathrm{H}_{2} \mathrm{C}=\mathrm{CHC}(\mathrm{O}) \mathrm{OCH}_{2} \mathrm{CH}_{2} \mathrm{CF}_{2} \mathrm{CF} 2 \mathrm{OCF} 2 \mathrm{CF} 2 \mathrm{SO}_{2} \mathrm{~F}$ (XVI)

To a $10 \mathrm{ml}$ two neck flask containing a Teflon coated stirring bar and fitted with a rubber septum was attached a claisen adaptor with a thermometer reaching to the bottom of the flask and a reflux condenser with a calcium drying tube. The flask was placed in an ice bath and $8.8 \mathrm{mmol}$ of freshly distilled acrylic acid added along with a trace of hydroquinone. Trifluoroacetic anhydride, $8.7 \mathrm{mmol}$, was slowly added with stirring at a rate that kept the solution below $15^{\circ} \mathrm{C}$. The ice bath was removed and the solution was stirred for an additional $15 \mathrm{~min}$. Addition of $8.7 \mathrm{mmol}$ of $\mathrm{HOCH}_{2} \mathrm{CH}_{2} \mathrm{CF}_{2} \mathrm{CF}_{2} \mathrm{OCF}_{2} \mathrm{CF}_{2} \mathrm{SO}_{2} \mathrm{~F}$ over $15 \mathrm{~min}$ caused the mixture to reach $25^{\circ} \mathrm{C}$. The solution was stirred an additional $90 \mathrm{~min}$. The solution was washed two times with $5 \mathrm{ml}$ of water, two times with $5 \%$ sodium bicarbonate and then again with water and a trace of hydroquinone was added. Distillation under dynamic vacuum $\left(0.5 \operatorname{torr} / 35^{\circ} \mathrm{C}\right)$ resulted in $1.02 \mathrm{~g}$ of product containing unreacted $\mathrm{HOCH}_{2} \mathrm{CH}_{2} \mathrm{CF}_{2} \mathrm{CF}_{2} \mathrm{OCF}_{2} \mathrm{CF}_{2} \mathrm{SO}_{2} \mathrm{~F}$, 
$\mathrm{H}_{2} \mathrm{C}=\mathrm{CHC}(\mathrm{O}) \mathrm{OCH}_{2} \mathrm{CH}_{2} \mathrm{CF}_{2} \mathrm{CF}_{2} \mathrm{OCF}_{2} \mathrm{CF}_{2} \mathrm{SO}_{2} \mathrm{~F}$ and polymerized product. Separation by column chromatography using $\mathrm{SiO}_{2}$ and diethyl ether resulted in $0.5 \mathrm{mmol}$ of $\mathrm{H}_{2} \mathrm{C}=\mathrm{CHC}(\mathrm{O}) \mathrm{OCH}_{2} \mathrm{CH}_{2} \mathrm{CF}_{2} \mathrm{CF}_{2} \mathrm{OCF}_{2} \mathrm{CF}_{2} \mathrm{SO}_{2} \mathrm{~F}$ (6\% yield)

The infrared spectrum had the following bands $\left(\mathrm{cm}^{-1}\right)$ : $3044(\mathrm{vw}) ; 2974(\mathrm{w}) ； 2925(\mathrm{w}) ; 2859(\mathrm{w}) ; 1797(\mathrm{w}) ; 1735(\mathrm{~s}) ;$ $1639(\mathrm{w}) ; 1622(\mathrm{w}) ; 1464(\mathrm{vs}) ; 1411(\mathrm{~m}) ; 1352(\mathrm{~m}) ; 1326(\mathrm{~m})$; 1299 (s)； 1273 (s)； 1247 (vs)； 1210 (vs)；1190(vs)；1151(vs); $1115(\mathrm{vs}) ; 1082(\mathrm{~s}) ; 989(\mathrm{~s}) ; 973(\mathrm{~m}) ; 910(\mathrm{w}) ; 821(\mathrm{~s}) ; 811(\mathrm{~s})$; $778(\mathrm{~m}) ; 706(\mathrm{w}) ; 646(\mathrm{~m}) ; 606(\mathrm{~s})$.

${ }^{1} \mathrm{H}$ NMR data $\left(\mathrm{CDCl}_{3}\right.$, int. TMS): Chemical shifts and coupling constants are in TABLE XI; relative integration areas $\mathrm{CH}_{2}=\mathrm{CH}(3.0), \mathrm{C}(0) \mathrm{CH}_{2}(1.9), \mathrm{CH}_{2} \mathrm{CF}_{2}$ (2.1).

${ }^{19} \mathrm{~F}$ NMR data $\left(\mathrm{CDCl}_{3}\right.$, ext. $\left.\mathrm{CFCl}_{3}\right)$ : Chemical shifts and coupling constants are in TABLE XI; relative integration areas $\mathrm{CH}_{2} \mathrm{CF}_{2}(2.1), \mathrm{CF}_{2} \mathrm{O}(2.1), \mathrm{OCF}_{2}(2.1), \mathrm{CF}_{2} \mathrm{~S}(2.1), \mathrm{SO}_{2} \mathrm{~F}$ $(1.0)$.

${ }^{13} \mathrm{C}$ NMR data $\left(\mathrm{CDCl}_{3}\right.$, int. TMS): Chemical shifts and coupling constants are in TABLE XII.

Mass spectral data (m/e, species): $\mathrm{EI}^{+} ; 398(\mathrm{M})^{+}, 127$ $\left(\mathrm{C}_{4} \mathrm{H}_{3} \mathrm{~F}_{4}\right)^{+}, 113\left(\mathrm{C}_{3} \mathrm{H}_{4} \mathrm{~F}_{2} \mathrm{O}\right)^{+}, 105\left(\mathrm{C}_{4} \mathrm{H}_{3} \mathrm{~F}_{2} \mathrm{O}\right)^{+}, 100\left(\mathrm{CF}_{2} \mathrm{CF}_{2}\right)^{+}, 99$ $\left(\mathrm{CH}_{2}: \mathrm{CHCO}_{2} \mathrm{CH}_{2} \mathrm{CH}_{2}\right)^{+}, 85\left(\mathrm{CH}_{2}: \mathrm{CHCO}_{2} \mathrm{CH}_{2}\right)^{+}, 78\left(\mathrm{C}_{3} \mathrm{H}_{4} \mathrm{~F}_{2}\right)^{+}, 73$ $\left(\mathrm{CH}_{2}: \mathrm{CHCO}_{2} \mathrm{H}_{2}\right)^{+}, 64\left(\mathrm{C}_{2} \mathrm{H}_{2} \mathrm{~F}_{2}\right)^{+}, 55\left(\mathrm{CH}_{2}: \mathrm{CHC}: \mathrm{O}\right)^{+}, 44\left(\mathrm{CO}_{2}\right)^{+}$. Anal. Calcd. for $\mathrm{C}_{9} \mathrm{H}_{7} \mathrm{~F}_{9} \mathrm{SO}_{5}: \mathrm{C}, 27.15 ; \mathrm{H}, 1.77 ; \mathrm{F}, 42.9$; S, 8.05\%. Found: C, 26.69; H, 1.99; F, 43.1; S, 7.83\%. 
Homopolymer of $\mathrm{OCH} 2 \mathrm{CHCH} 2 \mathrm{OCF} 2 \mathrm{CF} 2 \mathrm{SO} 2 \mathrm{~F}$ (XVII)

with boron trifluoride. Into a $10 \mathrm{ml}$ round bottom flask containing a Teflon coated stirring bar and fitted with a septum cap was added $0.91 \mathrm{~g}(3.6 \mathrm{mmol})$ of $\mathrm{OCH}_{2} \mathrm{CHCH}_{2} \mathrm{OCF}_{2} \mathrm{CF}_{2} \mathrm{SO}_{2} \mathrm{~F}$. After purging the vessel with dry nitrogen, $5 \mathrm{ml}$ of gaseous $\mathrm{BF}_{3}$ were injected via a gas syringe into the vessel while stirring the contents. Five minutes of continued stirring resulted in a thickening of the contents to which an additional $5 \mathrm{ml}$ of $\mathrm{BF}_{3}$ were added. Stirring ceased after 30 minutes due to the viscosity of the contents. The flask was evacuated for 18 hours to a final pressure of $\approx 5 \mu \mathrm{Hg}$ resulting in $0.89 \mathrm{~g}$ of dark brown viscous liquid.

An $0.23 \mathrm{~g}$ portion of the crude product was taken up in 2 $\mathrm{ml}$ of methylene chloride and washed five times with $2 \mathrm{ml}$ of distilled water. The light honey-colored product was again placed under vacuum for 2.5 days to give $0.21 \mathrm{~g}$ of a nearly colorless viscous product in an $89 \%$ overall yield.

The infrared spectrum of $\left[\mathrm{CH}_{2} \mathrm{CH}\left(\mathrm{CH}_{2} \mathrm{OCF}_{2} \mathrm{CF}_{2} \mathrm{SO}_{2} \mathrm{~F}\right) \mathrm{O}_{\mathfrak{n}}\right.$ had the following bands $\left(\mathrm{cm}^{-1}\right): 2966,2924,2899(w) ; 1455$ (vs); $1406(w) ; 1335(s) ; 1270$ (shoulder)； 1244 , 1202(vs)；1138, $1117(\mathrm{vs}) ; 1040(\mathrm{~m}) ; 1.005(\mathrm{~s}) ; 995(\mathrm{w}) ; 815,794(\mathrm{~s})$.

'H NMR data (CDCl, int TMS): Chemical shifts in TABLE XIV. No coupling constants or relative integration areas for broad unresolved resonances. 
${ }^{19} \mathrm{~F}$ NMR data $\left(\mathrm{CDCl}_{3}\right.$, ext. $\left.\mathrm{CFCl}_{3}\right):$ chemical shifts in TABLE XIV; no coupling constants for broad unresolved resonances. Relative integration areas: $\mathrm{OCF}_{2}(2.0) ; \mathrm{CF}_{2} \mathrm{~S}(2.1) ; \mathrm{SO}_{2} \mathrm{~F}$ $(1.0)$.

Analysis: calculated for $\left[\mathrm{CH}_{2} \mathrm{CH}\left(\mathrm{CH}_{2} \mathrm{OCF}_{2} \mathrm{CF}_{2} \mathrm{SO}_{2} \mathrm{~F}\right) 0\right]_{n}$ : C, $23.45 ; \mathrm{H}, 1.97 ; \mathrm{F}, 37.1 ; \mathrm{S}, 12.52$. Found: C, 23.53; H, 2.01; F, $36.6 ; \mathrm{S}, 12.37 \%$

The refractive index measured at $21^{\circ} \mathrm{C}$ was 1.3847 . with $\mathrm{H}_{2} \underline{\mathrm{SO}}_{4}$. To a $10 \mathrm{ml}$ round bottom flask containing a Teflon coated stirring bar and fitted with a reflux condenser topped by a $\mathrm{CaCl}_{2}$ drying tube was added $0.24 \mathrm{~g}$ of $\mathrm{OCH}_{2} \mathrm{CHCH}_{2} \mathrm{OCF}_{2} \mathrm{CF}_{2} \mathrm{SO}_{2} \mathrm{~F}(0.94 \mathrm{mmol}), 3.0 \mathrm{ml}$ of $\mathrm{CH}_{2} \mathrm{Cl}_{2}$ and thice drops of concentrated sulfuric acid. After heating to reflux with stirring for two hours the contents were cooled and washed ten times with $2 \mathrm{ml}$ of distilled water. Removal of the $\mathrm{CH}_{2} \mathrm{Cl}_{2}$ via vacuum resulted in $0.20 \mathrm{~g}$ of a honeycolored polymer for an $83 \%$ yield.

The NMR and infrared spectra were identical to those above. The refractive index measured at $21^{\circ} \mathrm{C}$ was 1.3976 . with $\mathrm{H}_{3} \mathrm{PO}_{1}$. A mixture of $0.75 \mathrm{~g}$ of $\mathrm{OCH}_{2} \mathrm{CHCH}_{2} \mathrm{OCF}_{2} \mathrm{CF}_{2} \mathrm{SO}_{2} \mathrm{~F}$ $(0.29 \mathrm{mmol})$ and $0.70 \mathrm{~g}$ of $83 \%$ phosphoric acid was stirred at $70-80{ }^{\circ} \mathrm{C}$ for $18 \mathrm{hr}$ in a $25 \mathrm{ml}$ round bottom flask containing a Teflon stirring bar. The reaction mixture was added to $5 \mathrm{ml}$ of distilled water and extracted twice with 25 ml of diethyl ether. Removal of the solvent via vacuum 
after drying over anhydrous sodium sulfate resulted in 0.70 $g$ of the viscous polymer in $100 \%$ yield.

The NMR and infrared spectra were identical to those above.

with photoinitiator UVI-6974. On a large clean watch glass was placed $0.88 \mathrm{~g}$ of $\mathrm{OCH}_{2} \mathrm{CH}_{2} \mathrm{OCF}_{2} \mathrm{CF}_{2} \mathrm{SO}_{2} \mathrm{~F}$ (3.4 mol) containing $2 \%$ by weight photoinitiator UVI-6974. The sample was irradiated 20 minutes with frequent swirling. The dark viscous product was taken up in $5 \mathrm{ml}$ of $\mathrm{CH}_{2} \mathrm{Cl}_{2}$, washed five times with $3 \mathrm{ml}$ of distilled water and placed under vacuum. An $0.81 \mathrm{~g}$ quantity $(92 \%$ yield) of a honey-colored viscous liquid was obtained.

The NMR and infrared spectra were identical to those above. The refractive index measured at $21^{\circ} \mathrm{C}$ was 1.3854 .

Copolymers of ${ }_{\mathrm{OCH}} \mathrm{CHCH}_{2} \mathrm{OCF} 2 \mathrm{CF}_{2} \mathrm{SO}_{2} \mathrm{~F}$ and Cyracure UVR-6110 $(x x)$

Mixtures of Cyracure UVR-6110 and $\mathrm{OCH}_{2} \mathrm{CHCH}_{2} \mathrm{OCF}_{2} \mathrm{CF}_{2} \mathrm{SO}_{2} \mathrm{~F}$, containing $3-4 \%$ by weight photoinitiator UVI-6974, were prepared in the ratios listed in TABLE XV. The cast films were irradiated for two minutes.

Infrared spectra of the copolymer films peeled from the glass substrates showed distinct bands at 3450,1729 and 864 $\mathrm{cm}^{-1}$ which varied in intensity with composition. Also found were bands overlapping with the homopolymer (XVII) at 1455, 
$1398,1363,1258,1181,1089,920$ and $660 \mathrm{~cm}^{-1}$. Subtraction of the bands attributable to the Cyracure UVR-6110 homopolymer resulted in spectra identical to the homopolymer (XVII) listed above.

Polymeric sulfonate salt $\left[\mathrm{OCH} 2 \mathrm{CH}\left(\mathrm{CH} 2 \mathrm{OCF} 2 \mathrm{CF} 2 \mathrm{SO}_{3} \mathrm{Na}\right)\right.$ ]n (XIIX):

Into a $10 \mathrm{Ml}$ round-bottom flask fitted with a reflux condenser topped with a calcium chloride drying tube and containing a T'eflon coated stirring bar was added $0.52 \mathrm{~g}$ (2.0 meq) of the epoxide homopolymer, $0.20 \mathrm{~g}$ ( $5 \mathrm{meq})$ of $\mathrm{NaOH}$ and $5 \mathrm{ml}$ of water. After heating the mixture to reflux for $3 \mathrm{~h}$ the water was removed by distillation. The crude product was dissolved $\mid$ in $1 \mathrm{ml}$ of hot water, slowly cooled then chilled in an ice bath. The flocculent NaF precipitate was remove via craig tube and to the aqueous solution was added $1 \mathrm{ml}$ of $95 \%$ ethanol. The solution was warmed, cooled then chilled in ice to yield more NaF. The solvent was removed and the product dried via vacuum to give $0.41 \mathrm{~g}$ of: solid product (75\% yield).

The infrared spectrum of $\left[\mathrm{OCH}_{2} \mathrm{CH}\left(\mathrm{CH}_{2} \mathrm{OCF}_{2} \mathrm{CF}_{2} \mathrm{SO}_{3} \mathrm{Na}\right)\right]_{\mathrm{n}}$ as a potassium bromide pellet had the following bands $\left(\mathrm{cm}^{-1}\right)$ : $3522(s) ； 2971(w) ； 2945(w) ； 2899(w) ; 1687(s) ； 1638(s) ;$ 1462 (s)；1412(s)；1335(vs)；1265(vs)；1216(vs)；1145(vs); $1096(\mathrm{vs}) ; 1025(\mathrm{~s}) ; 991(\mathrm{~s}) ; 941(\mathrm{~m}) ; 878(\mathrm{w}) ; 814(\mathrm{w}) ; 667(\mathrm{~s}) ;$ $632(s)$.

'H NMR data (CD3CN, ext. TMS): chemical shifts in TABLE XIV; no coupling constants or relative integration areas for 
broad unresolved resonances.

${ }^{19} \mathrm{~F}$ NMR data $\left(\mathrm{D}_{2} \mathrm{O}\right.$, ext. $\left.\mathrm{CFCl}_{3}\right):$ Chemical shifts in TABLE XIV; no coupling constants for broad peaks; relative integration areas $\mathrm{OCF}_{2}(1.0), \mathrm{CF}_{2} \mathrm{~S}(1.1)$. Polymeric sulfonic acid $\left[\mathrm{OCH} 2 \mathrm{CH}\left(\mathrm{CH}_{2} \mathrm{OCF} 2 \mathrm{CF} 2 \mathrm{SO} 3 \mathrm{H}\right)\right.$ ] n (XIX)

A solution containing $0.58 \mathrm{~g}(2.1 \mathrm{meq})$ of the polymeric sulfonate salt in $2 \mathrm{ml}$ of water was passed through a $9 \mathrm{ml}$ bed (200 meq exchange capacity) of Dowex 50W-X12 cation exchange resin in acidic form. The product was eluted in the first three $2 \mathrm{ml}$ fractions. The fractions were pooled and the water removed via vacuum to give $0.51 \mathrm{~g}$ (95\% yield) of a light brown glassy product. The $\mathrm{Ph}$ of an aqueous solution of a small portion of the product was below 2 as measured with $\mathrm{pH}$ paper.

The infrared spectrum of $\left[\mathrm{OCH}_{2} \mathrm{CH}\left(\mathrm{CH}_{2} \mathrm{OCF}_{2} \mathrm{CF}_{2} \mathrm{SO}_{3} \mathrm{H}\right)\right]_{\mathrm{n}}$ as a film cast from $\mathrm{CH}_{3} \mathrm{CN}$ on a potassium bromide window had the following band $\left(\mathrm{cm}^{-1}\right): 3191(\mathrm{~s}$, broad); $1771(\mathrm{~m}) ; 1722(\mathrm{~m})$; $1329(\mathrm{~m}) ; 1269(\mathrm{vs}) ； 1242$ (vs)；1145(s)；1098(s)；1021(s)； $907(\mathrm{~s}) ; 659(\mathrm{~m}) ; 629(\mathrm{~m})$.

${ }^{1} \mathrm{H}$ NMR data $\left(\mathrm{CD}_{3} \mathrm{CN}\right.$, ext. TMS): Chemical shifts in TABLE XIV; no coupling constants for broad unresolved peaks.

${ }^{19} \mathrm{~F}$ NMR data $\left(\mathrm{CD}_{3} \mathrm{CN}\right.$, ext. $\left.\mathrm{CFCl}_{3}\right)$ : chemical shifts in TABLE XIV; no coupling constants for broad resonances; relative integration area $\mathrm{OCF}_{2}(1.1), \mathrm{CF}_{2} \mathrm{~S}$ (1.1). 
Polyester $\left[\mathrm{C}(\mathrm{O}) \mathrm{CF}_{2} \mathrm{CF} 2 \mathrm{CF} 2 \mathrm{C}(\mathrm{O}) \mathrm{OCH} 2 \mathrm{CH}\left(\mathrm{CH}_{2} \mathrm{OCF} 2 \mathrm{CF} 2 \mathrm{SO} 2 \mathrm{~F}\right) \mathrm{O}\right] \mathrm{n}(\mathrm{XXI})$

Into a thick walled polymerization tube was placed $0.43 \mathrm{~g}$ $(1.6 \mathrm{mmol})$ of diol (XV) and $0.35 \mathrm{~g}(1.6 \mathrm{mmol})$ of hexafluoroglutaric anhydride. The contents of the tube were frozen at liquid nitrogen temperature, evacuated and then sealed. After heating to $100^{\circ} \mathrm{C}$ for two hours, the tube was opened and heated to $100^{\circ} \mathrm{C}$ under dynamic vacuum $12 \mathrm{hr}$. The resulting light brown extremely viscous product weighed 0.68 $g\left(87 \%\right.$ yield) and had a refractive index of 1.3818 at $21^{\circ} \mathrm{C}$.

The infrared spectrum of [C(O) $\left.\mathrm{CF}_{2} \mathrm{CF}_{2} \mathrm{CF}_{2} \mathrm{C}(\mathrm{O}) \mathrm{OCH}_{2} \mathrm{CH}\left(\mathrm{CH}_{2} \mathrm{OCF}_{2} \mathrm{CF}_{2} \mathrm{SO}_{2} \mathrm{~F}\right) \mathrm{O}\right]_{\mathrm{n}}$ had the following bands $\left(\mathrm{cm}^{-1}\right): 2973(\mathrm{Vw}) ; 1792(\mathrm{~s}) ; 1455(\mathrm{~s}) ; 1335(\mathrm{~m}) ; 1313(\mathrm{~m})$; $1242(\mathrm{~s}) ; 1201$ (s)；1146(s)；1051(m)；1015(w)；993(w); $946(w) ; 925(w) ; 810(\mathrm{~m}) ; 747(w) ; 717(w) ; 657(\mathrm{~m}) ; 608(\mathrm{~m})$.

${ }^{1} \mathrm{H}$ NMR data $\left(\mathrm{CD}_{3} \mathrm{CN}\right.$, ext. TMS): Chemical shifts in TABLE XVI; no coupling constants for broad unresolved resonances.

${ }^{19} \mathrm{~F}$ NMR data $\left(\mathrm{CD}_{3} \mathrm{CN}\right.$, ext. $\left.\mathrm{CFCl}_{3}\right)$ : chemical shifts and coupling constants in TABLE XVI. Relative integration areas: $O C(O) \mathrm{CF}_{2} \mathrm{CF}_{2} \mathrm{CF}_{2} \mathrm{C}(\mathrm{O}) \mathrm{O}, 4.0 ; \mathrm{OC}(\mathrm{O}) \mathrm{CF}_{2} \mathrm{CF}_{2} \mathrm{CF}_{2} \mathrm{C}(0) 0,1.9$; $\mathrm{CH}_{2} \mathrm{OCF}_{2}, 1.9 ; \mathrm{CF}_{2} \mathrm{~S}, 1.9 ; \mathrm{SO}_{2} \mathrm{~F}, 1.0$.

Anal. Calcd. for $\mathrm{C}_{10} \mathrm{H}_{5} \mathrm{~F}_{11} \mathrm{SO}_{7}: \mathrm{C}, 25.12 ; \mathrm{H}, 1.05 ; \mathrm{F}, 43.7 \%$. Found: C, $24.87 ; \mathrm{H}, 1.05 ; \mathrm{F}, 43.6 \%$.

Urethane Polymer (XXII)

Bulk Method. To a thick walled polymerization tube containing a Teflon coated stirring bar was added $0.56 \mathrm{~g}$ 
(2.0 mmol) of dial (XV), $0.34 \mathrm{~g}(2.0 \mathrm{mmol})$ of $1,6-\mathrm{di}$ isocyanohexane, and $2 \mathrm{ml}$ of chlorobenzene. The contents of the vial were frozen at liquid nitrogen temperature and the tube sealed. Vigorous stirring for $12 \mathrm{hr}$ at $100^{\circ} \mathrm{C}$ resulted in the formation of a slightly yellow polymeric sponge-like product. The product was removed, cut into small pieces, washed 10 times with $5 \mathrm{ml}$ of diethyl ether and dried under vacuum to give $0.60 \mathrm{~g}$ of light yellow product in $67 \%$ yield.

\section{Film Method}

A portion of a mixture of $0.40 \mathrm{~g}(1.4 \mathrm{mmol})$ of diol (XV) and $0.24 \mathrm{~g}(1.4 \mathrm{mmol})$ of 1,6 -diisocyanohexane was spread on a clean glass plate and heated to $95^{\circ} \mathrm{C}$ for thirty minutes under a nitrogen atmosphere. The tough flexible film ias removed from the plate and washed by continuolis extraction with acetone to remove unreacted monom $=r$.

The infrared spectrum of $(X x \geq 1)$ had the following bands $\left(\mathrm{cm}^{1}\right): \quad 3339(\mathrm{w}) ; 2938(\mathrm{~m} ; ; 2681(\mathrm{~m}) ; 1750(\mathrm{~s}) ; 1714(\mathrm{~s}) ;$ $1532(\mathrm{~m}) ; 1455(\mathrm{~s} ; ; 1250(\mathrm{~s}) ; 1145(\mathrm{~s}) ; 1068(\mathrm{~s}) ; 997$ (m with sh. at $811 ; ; 765(\mathrm{~m}) ; 653(\mathrm{~m}) ; 610(\mathrm{w})$.

Anal. Calcd. for 1:6 polymer $\mathrm{C}_{53} \mathrm{H}_{79} \mathrm{~F}_{5} \mathrm{SN}_{12} \mathrm{O}_{17}: \mathrm{C}, 49.60 ; \mathrm{H}$, $26.20 ; \mathrm{F}, 7.4 \%$. Found: C, 46.72; H, 6.90; F, 7.4\%. Polymer of $\mathrm{CH}_{2} \equiv \mathrm{CHC}(\mathrm{O}) \mathrm{OCH}_{2} \underline{\mathrm{CH}}_{2} \underline{\mathrm{CF}}_{2} \mathrm{CF}_{2} \underline{\mathrm{OCF}}_{2} \underline{\mathrm{CF}}_{2} \underline{\mathrm{SO}}_{2} \mathrm{~F}$ (XXIII)

Solution Polymerization. Into a $5 \mathrm{ml}$ round bottom flask fitted with a septum cap and a reflux condenser topped by a calcium chloride drying tube was placed a Teflon coated stirring bar and $2 \mathrm{ml}$ of distilled acetone containing 0.72 
mmol $(0.29 \mathrm{~g})$ of the acrylate monomer (XVI). Half of the initiator solution, prepared from $0.06 \mathrm{mmol}(0.01 \mathrm{~g})$ of $\left[\left(\mathrm{CH}_{3}\right)_{2} \mathrm{C}(\mathrm{CN})\right]_{2} \mathrm{~N}$ (AIBN) in $1 \mathrm{ml}$ of acetone, was added to the solution with stirring. After heating to reflux for two hours the remainder of the initiator was added and the solution was again heated for two hours. Removal of the solvent via vacuum resulted in $0.27 \mathrm{~g}, 93 \%$ yield, of a glassy honey-colored solid.

The infrared spectra of $\left[\mathrm{CH}_{2} \mathrm{CH}\left(\mathrm{CO}_{2} \mathrm{CH}_{2} \mathrm{CH}_{2} \mathrm{CF}_{2} \mathrm{CF}_{2} \mathrm{OCF}_{2} \mathrm{CF}_{2} \mathrm{SO}_{2}\right)\right]_{\mathrm{n}}$ (XXIII) had the following bands $\left(\mathrm{cm}^{-1)} ; 2966(w), 2931\right.$ (w), 1795 (w), 1742 (s), 1463 (vs), 1351 (m), 1325 (m), 1304 (m), 12246 (vs), 12202 (vs), 1149 (vs), 1116 (vs), 1078 (s), 1008 $(\mathrm{m}), 987(\mathrm{~m}), 905(\mathrm{w}), 823(\mathrm{~s}), 779(\mathrm{~m}), 705(\mathrm{w}), 646(\mathrm{~m})$.

${ }^{1} \mathrm{H}$ NMR data (acetone- $d_{6}$, int. TMS): Chemical shifts and coupling constants in TABLE XVII; relative integration area $-\mathrm{CH} 2-\mathrm{CH}-(3.0), \mathrm{CO}_{2} \mathrm{CH}_{2}(1.7), \mathrm{CH}_{2} \mathrm{CF} 2$ (1.9).

${ }^{19} \mathrm{~F}$ NMR data (acetone- $d_{6}$, ext. $\mathrm{CFCl}_{3}$ ): Chemical shifts and coupling constants in TABLE XVII; relative integration area $\mathrm{CH}_{2} \mathrm{CF}_{2}(2.60), \mathrm{CF}_{2} \mathrm{O}(1.9), \mathrm{OCF}_{2}(2.0), \mathrm{CF}_{2} \mathrm{~S}(2.0), \mathrm{SO}_{2} \mathrm{~F}(1.0)$.

Anal. Calcd. for $\mathrm{C}_{9} \mathrm{H}_{7} \mathrm{~F}_{9} \mathrm{SO}_{5}: \mathrm{C}, 27.15 ; \mathrm{H}, 1.77 ; \mathrm{F}, 42.9 ; \mathrm{S}$, $8.05 \%$. Found: C, $23.13 ; \mathrm{H}, 1.53 ; \mathrm{F}, 46.3 ; \mathrm{S}, 6.86$.

Bulk Photopolymerization. An $0.0377 \mathrm{~g}$ portion of a solution prepared from $0.096 \mathrm{mmol}(0.0383 \mathrm{~g})$ of acrylate monomer and $0.0012 \mathrm{mmol}(0.0002 \mathrm{~g}, 0.5 \mathrm{wt} \%)$ of azo(bis) isobutyronitrile was placed in a $5 \mathrm{ml}$ Teflon cup and irradiated with a horizontal 450 watt Hanovia mercury lamp for five 
minutes. A small quantity of the viscous liquid removed for infrared analysis revealed a spectrum identical to that above. Further irradiation for a total of thirty minutes resulted $0.0347 \mathrm{~g}(99 \% \mathrm{yield})$ of a light-brown viscous product.

Film Forming Photopolymerization. A single drop of the above solution was placed between two sodium chloride infrared windows. The windows were placed under a horizontal 450 watt Hanovia mercury lamp for five minutes after which the windows were found to be well adhered. The infrared spectrum was identical to that above for the bulk polymer. 
CHAPTER VI

CONCLUSION

The purpose of this work was to synthesize monomeric and polymeric fluoroalkyl sulfonyl fluorides, sulfonate salts and sulfonic acids suitable for use as electrolytes and coatings. While the synthesis and properties of the individual compounds prepared are discussed in the previous chapters, it seems fitting to summarize the results with a number of conclusions.

The use of $\beta$-fluorosultones and their derivatives led to the synthesis of a variety of simple monomeric fluoroalkyl sulfonyl fluorides, sulfonate salts, and sulfonic acids; $\mathrm{CHF}\left(\mathrm{OCF}_{2} \mathrm{CF}_{2} \mathrm{SO}_{2} \mathrm{~F}\right)_{2}, \mathrm{CF}_{2}\left(\mathrm{OCF}_{2} \mathrm{CF}_{2} \mathrm{SO}_{2} \mathrm{~F}\right)_{2}, \mathrm{CH}_{2}\left(\mathrm{OCF}_{2} \mathrm{CF}_{2} \mathrm{SO}_{3} \mathrm{Na}\right)_{2}$, $\mathrm{CF}_{2}\left(\mathrm{OCF}_{2} \mathrm{CF}_{2} \mathrm{SO}_{3}\right)_{2} \mathrm{Ca}$, and $\mathrm{CF}_{2}\left(\mathrm{OCF}_{2} \mathrm{CF}_{2} \mathrm{SO}_{3} \mathrm{H}\right)_{2}$. Additional compounds included; $\mathrm{FC}\left(\mathrm{CF}_{3}\right)_{2} \mathrm{OCH}_{2} \mathrm{CH}_{2} \mathrm{OCF}_{2} \mathrm{CF}_{2} \mathrm{SO}_{2} \mathrm{~F}$ (prepared using the adduct of hexafluoroacetone and silver fluoride), $\mathrm{CH}_{3} \mathrm{OCF}_{2} \mathrm{CF}_{2} \mathrm{SO}_{2} \mathrm{~F}$ (prepared as a substrate for free-radical substitution reactions of fluorinated species), and the pentafluorosulfur lithium sulfonate salts $\mathrm{SF}_{5} \mathrm{CHFSO}_{3} \mathrm{Li}$ and $\mathrm{SF}_{5} \mathrm{CF}_{2} \mathrm{SO}_{3} \mathrm{Li}$.

of the above compounds, the perfluorinated disulfonic acid $\mathrm{CF}_{2}\left(\mathrm{OCF}_{2} \mathrm{CF}_{2} \mathrm{SO}_{3} \mathrm{H}\right)_{2}$, and the lithium salts $\mathrm{SF}_{5} \mathrm{CHFSO}_{3} \mathrm{Li}$ and 
$\mathrm{SF}_{5} \mathrm{CF}_{2} \mathrm{SO}_{3} \mathrm{Li}$, show promise for use in electrochemical devices. A variety of perfluorinated sulfonic acids have been evaluated for use in fuel cells (2). Long-chain disulfonic acids were found to give the better conductivity and higher oxygen solubility. These characteristics make $\mathrm{CF}_{2}\left(\mathrm{OCF}_{2} \mathrm{CF}_{2} \mathrm{SO}_{3} \mathrm{H}\right)_{2}$ a candidate for further investigation in fuel cell applications. For the lithium salts, $\mathrm{SF}_{5} \mathrm{CHFSO}_{3} \mathrm{Li}$ and $\mathrm{SF}_{5} \mathrm{CF}_{2} \mathrm{SO}_{3} \mathrm{Li}$, conductivity measurements in poly (ethylene oxide) have generated enough interest to warrant additional synthesis of these compounds for lithium battery studies. Novel compounds containing both alcohol and fluoroalkyl sulfonyl functional groups were also prepared; the chlorohydrin $\mathrm{ClCH}_{2} \mathrm{CH}(\mathrm{OH}) \mathrm{CH}_{2} \mathrm{OCF}_{2} \mathrm{CF}_{2} \mathrm{SO}_{2} \mathrm{~F}$, the benzyl ethers $\mathrm{HOCH}_{2} \mathrm{CH}\left(\mathrm{OCH}_{2} \mathrm{C}_{6} \mathrm{H}_{5}\right) \mathrm{CH}_{2} \mathrm{OCF}_{2} \mathrm{CF}_{2} \mathrm{SO}_{2} \mathrm{~F}$ and $\mathrm{C}_{6} \mathrm{H}_{5} \mathrm{CH}_{2} \mathrm{OCH}_{2} \mathrm{CH}(\mathrm{OH}) \mathrm{CH}_{2} \mathrm{OCF}_{2} \mathrm{CF}_{2} \mathrm{SO}_{2} \mathrm{~F}$, and the diol $\mathrm{HOCH}_{2} \mathrm{CH}(\mathrm{OH}) \mathrm{CH}_{2} \mathrm{OCF}_{2} \mathrm{CF}_{2} \mathrm{SO}_{2} \mathrm{~F}$.

The diol was found to be useful for the preparation of two polymeric fluoroalkyl sulfonyl fluorides: the polyester $\left[\mathrm{C}(\mathrm{O}) \mathrm{CF}_{2} \mathrm{CF}_{2} \mathrm{CF}_{2} \mathrm{C}(\mathrm{O}) \mathrm{OCH}_{2} \mathrm{CH}\left(\mathrm{CH}_{2} \mathrm{OCF}_{2} \mathrm{CF}_{2} \mathrm{SO}_{2} \mathrm{~F}\right) \mathrm{O}\right] \mathrm{n}$ and a polyurethane. other polymeric compounds prepared were; the sulfonyl fluoride, sulfonate salt and sulfonic acid $\left[\mathrm{OCH}_{2} \mathrm{CH}\left(\mathrm{CH}_{2} \mathrm{OCF}_{2} \mathrm{CF}_{2} \mathrm{SO}_{2} \mathrm{~F}\right)\right] n,\left[\mathrm{OCH}_{2} \mathrm{CH}\left(\mathrm{CH}_{2} \mathrm{OCF}_{2} \mathrm{CF}_{2} \mathrm{SO}_{3} \mathrm{Na}\right)\right] n$ and $\left[\mathrm{OCH}_{2} \mathrm{CH}\left(\mathrm{CH}_{2} \mathrm{OCF}_{2} \mathrm{CF}_{2} \mathrm{SO}_{3} \mathrm{H}\right)\right] n$ prepared by homopolymerization of the epoxide $\mathrm{OCH}_{2} \mathrm{CHCH}_{2} \mathrm{OCF}_{2} \mathrm{CF}_{2} \mathrm{SO}_{2} \mathrm{~F}$, a cross-linked copolymer of the same epoxide; and the fluoroalkyl sulfonyl fluoride polyacrylate $\left[-\mathrm{CH}_{2}-\mathrm{CH}-\left(\mathrm{CO}_{2} \mathrm{CH}_{2} \mathrm{CH}_{2} \mathrm{CF}_{2} \mathrm{CF}_{2} \mathrm{OCF}_{2} \mathrm{CF}_{2} \mathrm{SO}_{2} \mathrm{~F}\right)\right] n$ prepared from the acrylate ester $\mathrm{H}_{2} \mathrm{C}=\mathrm{CHC}(\mathrm{O}) \mathrm{OCH}_{2} \mathrm{CH}_{2} \mathrm{CF}_{2} \mathrm{CF}_{2} \mathrm{OCF}_{2} \mathrm{CF}_{2} \mathrm{SO}_{2} \mathrm{~F}$. 
The ability to prepare polymers without the use of solvents is highly desirable. The polyacrylate, copolymeric epoxides and polyurethane were formed as bulk polymers or free-standing films generated in situ. The potential applications of these compounds and the synthesis of other similar compounds is being further pursued by this laboratory. 
REFERENCES

1. Gas Research Institute Digest, Volume 7, No.2.

2. (a) Appleby, A.J.; Boruka, A. J. Electrochem. Soc. 1969, 116, 1212. (b) Appleby, A.J.; Baker, B.S. J. Electrochem. Soc. 1978, 125, 424 .

3. Wesseler, E.P.; Iltis, R.; Clark, L.C. J. Fluorine Chem. 1977, 9, 137 .

4. Lemons, R.J. Power Sources 1990, 29, 251.

5. Eisenberg, A.; Yeager, H.L. (eds.) Perfluorinated Ionomer Membranes, ACS Symposium Series 180, American Chemical Society, Washington, D.C., 1982

6. Seko, M.S.; Ogawa, S.; Kimoto, K. Ch. 15, in Ref. 5.

7. McCain, G.H.; Covich, M.J. J. Electrochem. Soc. 1984, 131,1350 .

8. Armand, M.B.; Chabagng, J.M.; Duclot, M.J. in Fast Ion Transport in Solids, Mundy, J.N.; Shenoy, G.K. (eds.), elsevier, North-Holland, New York, 1979, p. 131.

9. Gauthier, M.; Belanger, A.; Kapfer, B.; Vassort, G. in Polymer Electrolyte Reviews 2, MacCallum, J.R.; Vincent, C.A. (eds.), Elsvier Applied Science.

10. Olah, G.A.; Iyer, P.S.; Surya, P. Synthesis 1986, 7, 513 .

11. Bunyagldj, C.; Plotrowska, H.; Aldridge, M.H. J. Chem. Eng. Data 1981, 26, 344 .

12. Canich, J.M.; Ludvig, M.M.; Gard, G.L.; Shreeve, J.M. Inorg. Chem. 1984, 23, 4403 .

13. Terjeson, R.J.; Mohtasham, J.; Sheet's, R.M.; Gard, G.L. J. Fluorine Chem. 1988, 38, 3 .

14. Mohtasham, J.; Gard, G.L. Coprd. Chem. Rev. 1992, 112, 47 .

15. Saffarain, H.; Ross, P.; Behr, F.; Gard, G.L. Electrochem. Soc. 1992, 139, 2391. 
16. Vallee, A, ; Besner, S.; Prud'homme, J. Electrocemica Acta 1992, 37, 1579.

17. Sondheimer, S.J.; Bunce, N.J.; Fyfe, C.A. Rev. Macromol. Chem. Phys. 1986, C26(3), 353.

18. Groh, W.; Zimmerman, A. Macromolecules 1991, 24, 6660.

19. Cisar, A. The proceedings of the Electrochemical society symposium on Modeling of Batteries and Fuel cells, 1991.

20. Grot, W. in Encyclopedia of Polymer science and Engineering, Vol. 6, H.F. Marks, N.M. Bihales, C.G. overgerger, G. Menges, J.I. Kroschwitz (editors), John Wiley \& Sons, New York.

21. Stinson, S.C. Chem! and Eng. News, 1982, 60, 22 .

22. Suhara, M.; Aria, K. United States Patent 4,259,226 (1981), and Grot, W.G. United States Patent 3,692,569 $(1972)$.

23. Cavanaugh, R.J.; Calkins, W.H. U.S. Pat. 3,882,093 (1975).

24, Krespan, C.G. U. S. Pat. 4,394,650 (1982).

25, Krespan, C.G. U. S. Pat. 4,273,729 (1977).

26. Krespan, C.G. Ger! Offen. 2,753,886 (1978), U.S. Pat. App1. 747,029 (1976).

27. Ezzell, B.R.; Carl, W.P. Eur. Pat. Appl. EP 289,869, (1988), U.S. Pat Appl. 47,814 (1987).

28. Miyake, H.; Watakabe, A. ; Oda, Y. Jpn. Kokai Tokkyo Koho Jap. Pat. 60,250,009 [85,250,009], (1985).

29. Miyake, H. ; Watakabe, A. Jpn. Kokai Tokkyo Koho Jap. Pat. 62, 288,614 [87,288,614], (1987).

30. Miyake, H.; Watakabe, A. Jpn. Kokai Tokkyo Koho Jap. Pat. 62, 228,617 [87,228,617], (1987).

31. Miyake, H.; Watakabe, A. Jpn. Kokai Tokkyo Koho Jap. Pat. 62, 288,616 [87,288,616], (1987).

32, Caporiccio, G.; Bargigia G.; Guidetti, G. Ger. Offen. $2,735,210(1978)$.

33. Fielding, H.C.; Gamlen, H.P.; Shirley, I.M. Eur. Pat. 
Appl. EP 331,321 (1989).

34. Kostov, G.K.; Kotov, S.V.; IVanov, G.D.; Todorova, D. J. Appl. Polym. Sci, 1993, 47.

35. Takada, K.; Izeki, Ұ.; Takesue, M. Jpn. Kokai Tokkyo Koho JP $0129,440\left[\begin{array}{lll}89 & 29,440]\end{array}\right.$.

36. Kawaguchi, T.; Hagiwara, T.; Tamura, Y.; Hayashi, Y.; Negishi, S. Jap. Kokai $(7833,296)$.

37. Momose, T.; Ishigaki, I.; Okamoto, J. J. Appl. Polym. SCi. 1988, 36, 1366,

38. Chen, L.F.; Mohtasham, J.; Gard, G.L. J. Fluorine Chem. $1990,46,39$.

39. Chen, L.F.; Mohtasham, J.; Gard, G.L. J. Fluorine Chem. $1990,46,21$.

40. Howells, R.D.; McCown, J.D. Chem. Revs. 1977, 77, 69

41. Gard, G.L.; Waterfeld, A.; Mews, R.; Mohtasham, J.; Winter, R. Inorg. Chem. 1990, 29, 4588 .

42. Chen, L.F.; Mohtasham, J.; Gard, G.L. J. Fluorine Chem. $1989,43,329$.

43. England, D.C.; Dretrich, M.A.; Linsey, R.V. J. Am. Chem. Soc. $1960,82,6181$.

44. Gordon, A.J.; Ford, A.F. in "The Chemists Companion", John Wiley \& Sons, New York, 1972.

45. W.H. Pearlson; J. Fluorine Chem. 1986, 32, 29.

46. Rozhkov, I.N. in "Organic Electrochemistry" 2nd edition, M.M. Baizer, H. Lund (editors)., Marcel Dekker Inc., New York, 1983, pages $\mid 805-825$ and references cited therein.

47. Gambaretto, G.P.; Napoli, M.; Conti, L.; Scipione, A.; Armelli, R.J. Fluorine Chem. 1984, 27, 149.

48. Olah, G.A.; Shih, J.G.; Krishnamurthy, V.V.; Singh, B.P. J. Amer. Chem. Soc. 19814, 106, 4492 .

49. Marchionni, G.; Spartaro, F.; De Pasquale, R.J. J. Fluorine Chem. 1990, 49, 217.

50. Hollitzer, E.; Sartori, P. J. Fluorine Chem. 1987, 35, 329. 
51. Chen, L.F.; Mohtasham, J.; Gard, G.L. J. Fluorine Chem. $1990,48,107$.

52. Chen, L.F.; Mohtasham, J.; Gard, G.L. J. Fluorine Chem. $1990,49,331$.

53. Katsuhara, Y.; Hammaker, R.M.; Des Marteau, D.D. Inorg. Chem. 1980, 19, 607 .

54. Brown, J.K.; Morgan, K.J. in "Advances in Fluorine Chemistry", Vol. 4, (1965), 256.

55. Evans, F.W.; Litt, M.H.; Weider, A.M.; Avonda, F.P. J. Org. Chem., 1968, 33, 1839.

56. Howard, E.G.; Sargeant, P.B. ; Krespan, C.G. J. Amer. Chem. Soc. 1967, 89, 1422 .

57. Graham, D.P.; Weinmayr, V. J. Org.. Chem. 1966, 31, 957.

58. Young, D.E.; Anderson, L.R.; Gould, D.E.; Fox, W.B. Tetrahedron Lett. 1969, 723.

59. Rosenberg, R.M.; Muetterties, E.C. Inorg. Chem. 1962, 1,176 .

60. Prager, J.H.; Thompson, P.G. J. Amer. Chem. Soc. 1965, 87,230 .

61. (a) Shepard, W.A. J. Amer. Chem. Soc. 1962, 62, 3072 (b) Thrasher, J.S.; Nielson, J.B.; Bott, S.G.; McClure, D.J.; Morris, S.A.; Atwood, J.L. Inorg. Chem. $1988,27,570$ (c) Gard, G.L.; Woolf, C. J. Fluorine Chem. 1971/72, 1, 487 (d) Canich, J.M.; Ludvig, M.M.; Paudler, W.W.; Gard, G.L.; Schreeve, J.M. Inorg. Chem. 1985, 24, 3668 (e) Hansen, J.C.; Savu, P.M. U.S. Patent $5,159,105$ (1992).

62. (a) Raistric, I.D. in "Diaphragms, separators, and Ion-Exchange Membranes", Van Zee, J.W.; White, R.E.; Kinoshita, K.; Burney, H.S. (Eds) The Electrochemical Society, Pennington, N.J. 1986, P. 172 . Ticianelli, E.A.; Deruin, C.R.; Srinivasan, S.J. Electroanal.Chem. 1988, 251, 275. (c) Gottesfeld, S.; Raistrick, I.D.; Srinivasan, S.J.; Springer, T.E.; Ticianalli, E.; Deruin, C.R.; Beery, J.; Sherman, R.J. proceedings of the 1988 Fuel cell Seminar, Long Beach, CA. (1988).

63. Parker, R.E.; Issacs, N.S. Chem. Rev. 1959, 59, 737. 
64. (a) Stacey, M.; Tatlow, J.C.; Sharpe A.G. (eds.), in "Advances in Fluorine Chemistry", Vol. 3, Butterworths, London, 595. (b) Hudlicky, M. in "chemistry of Fluorine Compounds", 2nd. Revised Edition, Ellis Harwood, Ltd., West Sussex, England.

65. Socrates, G. in "Infrared Characteristic Group Frequencies", John+Wiley \& Sons, New York, 1980.

66. Gard, G.L.; Hamel, N.N.; Mohtasham, J.; Waterfeld, A. ; Mews, R. J. Fluorine Chem. 1991, 55, 313.

67. Katritzy, A.R.; Rees, C.W. ; Lewars, E.G. Comprehensive Heterocyclic Chemistry, Vol. 7, Pegamon Press, 1984, W. Lwowski, editor, pages 14 and 99 with references cited therein.

68. Posner G.H.; Rogers, D.Z. J. Amer. Chem. Soc. 1977, 99, 8208 .

69. Iranpoor, N.; Baltork, I.M. Synth. Comm. 1990, 20, 2789

70. (a) Codding, D.W.; Reid, T.S.; Ahlbrecht, A.H.; Smith, G.H.; Husted, D.R.|J. Polym. Sci. 1955, 15, 515. (b) Bovey, F.A.; Abere! F.F. J. Polym. Sci. 1955, 15, 537. (C) Abere, J.F.; Rathman, G.B.; Sandberg, C.L. J. Polym. Sci. 1955, 15, 520.

71. Pfeffer, P.E.; Silbert, L.S. J. Org. Chem. 1976, 41, 1373 .

72. Lee, H.; Neville, K. in "Handbook of Epoxy Resins", McGraw-Hill, Inc. New York, (1967).

73. McGrath, J.E. (editor), Ring opening Polymerization, Kinetics, Mechanisins, and synthesis, ACS Symposium Series, 286, 1985.।

74. Polymer synthesis, Vol. I, Sandler, R.S.; Karo, W. editors, Academic Press, New York, (1992) page 70 and references cited threin.

75. Hurd, C.D.; Blunk, C.H. J. Amer. Chem. SoC., 1938, 60, 2419 .

76. Trischler, F.D.; Hollander, J. J. Polym. Sci., Part A-1 $1969,7,971$.

77. Polymer synthesis, Vol. I, Sandler, R.S.; Karo, W. editors, Academic Press, New York, (1992) page 233 and references cited threin. 
78. Dieterich, D.; Grigat, E. ; Hahn, W. in "Polyurethane Handbook", Macmillan Publishing Company, New York, (1985) pages 7-63.

79. Luskin, L.S.; Meyer, R.J. in "Encyclopedia of Polymer Science and Engineering", Vol. 1, second edition, H.F. Marks, N.M. Bihales, C.G. Overgerger, G. Menges, J.I. Kroschwitz (editors), John Wiley \& Sons, New York (1984), pages 234-314.

80. Polymer synthesis, Vol. I, Sandler, R.S.; Karo, W. editors, Academic Press, New York, (1992) page 4 and references cited threin.

81. Polymer synthesis, Vol. I, Sandler, R.S.; Karo, W. editors, Academic Press, New York, (1992) page 320 and references cited threin.

82. Okamoto, $Y$. in Cationic Ring-opening polymerization of Epichlorohydrin in the Presence of Ethylene Glycol, Ring-opnening polymerizations, ACS Symposium Series 286, ACS Publishing, Washington, D.C., (1985).

83. (a) Atlas of Polymer Morphology, oxford University Press, 1989, A.E. Woodward, editor. (b) Handbook of Polymer Scienc and Technology, Vol. 1, Marcell Dekker Inc., 1989, N.P. Cheremisinoff, editor.

84. DeMarco, R.A.; Couch, D.A.; Shreeve, J.M. J. Org. Chem. $1972,37,3332$.

85. Majid, A.; Shreeve, J.M. J. Org. Chem. 1973, 38, 4028. 
APPENDIX A

INFRARED SPECTRA 


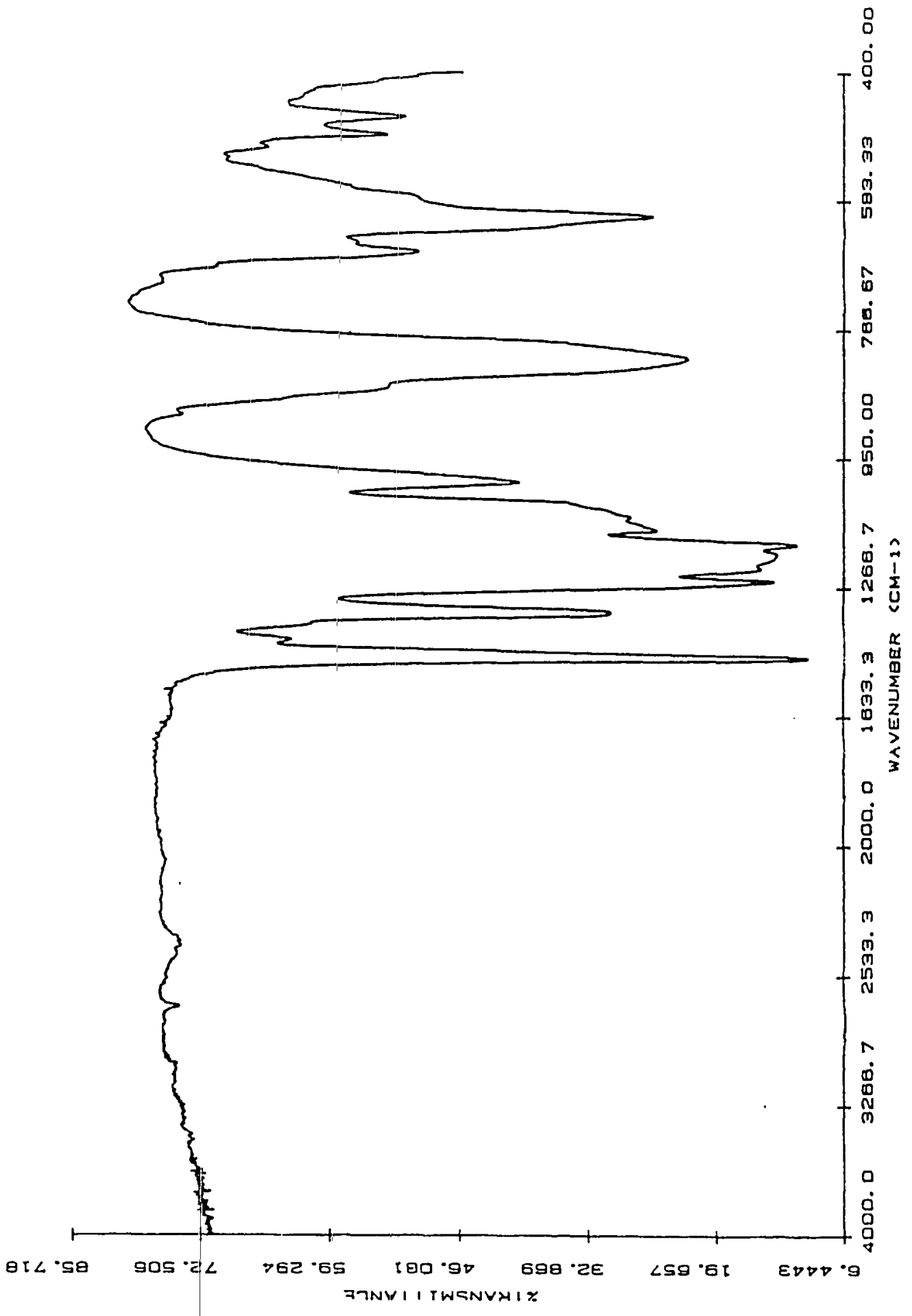

Figure 1. Infrared spectrum of CHF(OCF2CF2SO2F) 2 (II). 


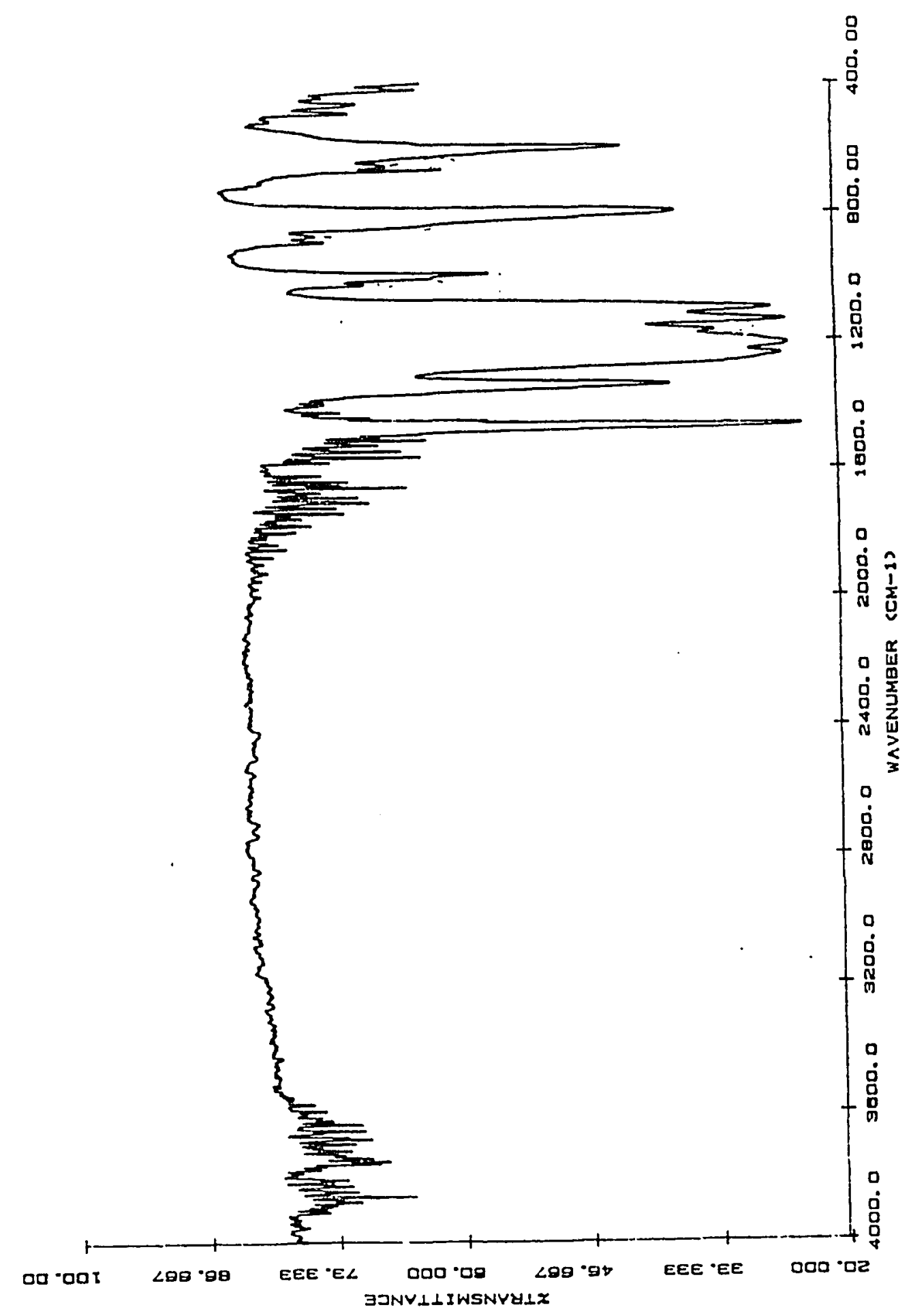

Figure 2. Infrared spectrum of $\mathrm{CF} 2(\mathrm{OCF} 2 \mathrm{CF} 2 \mathrm{SO} 2 \mathrm{~F}) 2$ (III). 


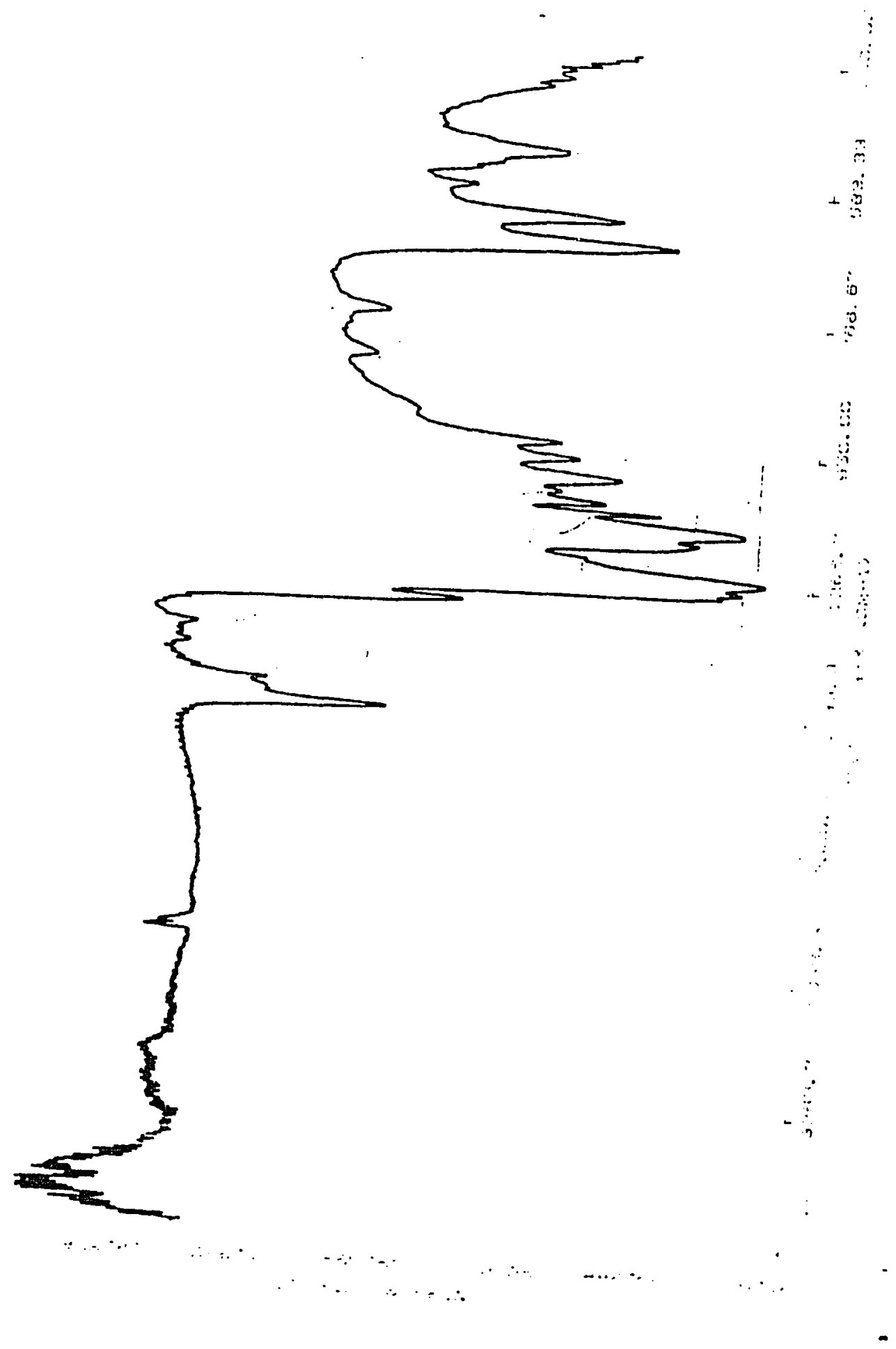

Figure 3. Infrared spectrum of $\mathrm{CH}_{2}$ (OCF2CF2SO3Na) 2 (IV). 


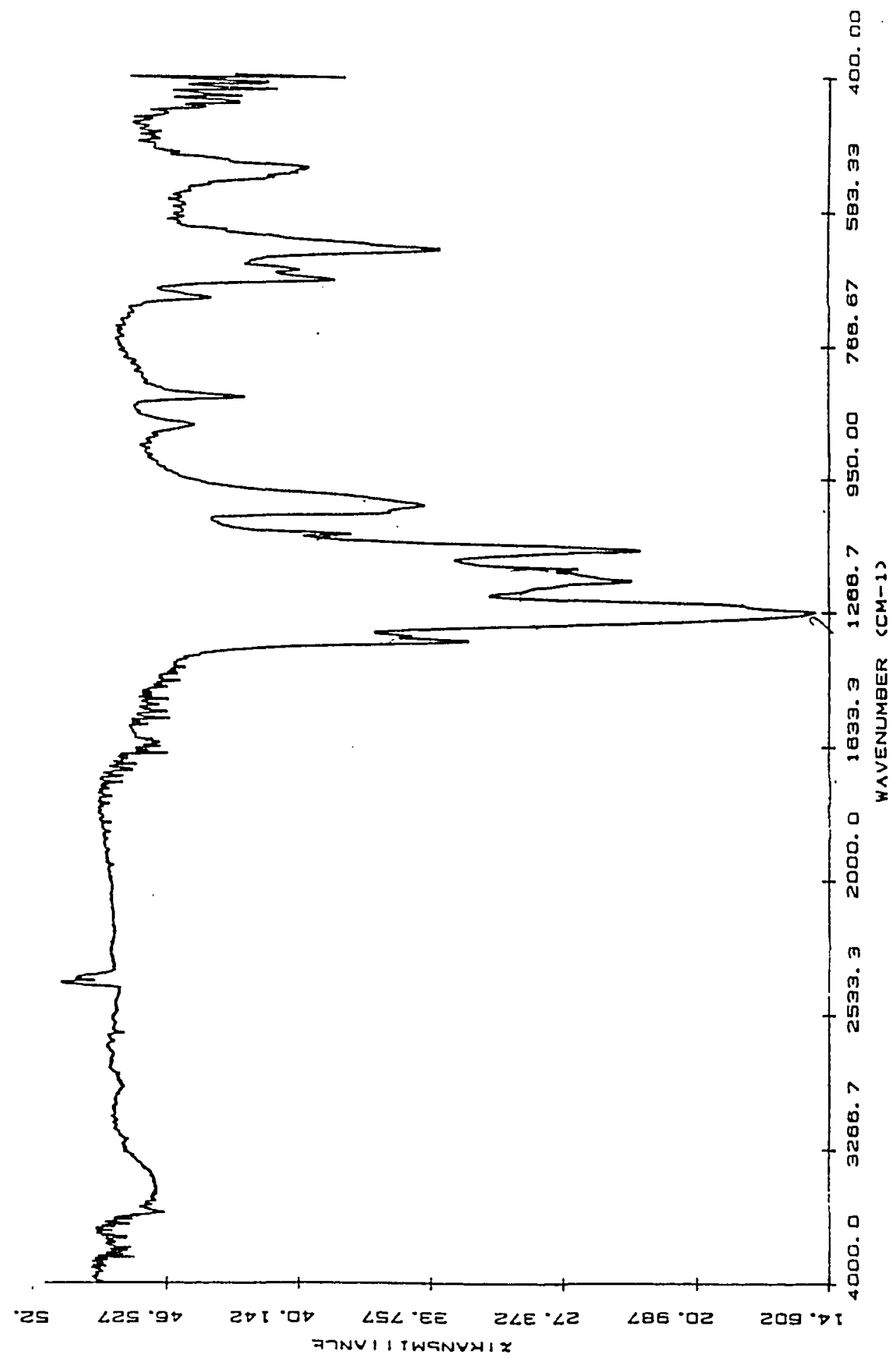

Figure 4. Infrared spectrum of CF2(OCF2CF2SO3) $2 \mathrm{Ca}(\mathrm{V})$. 


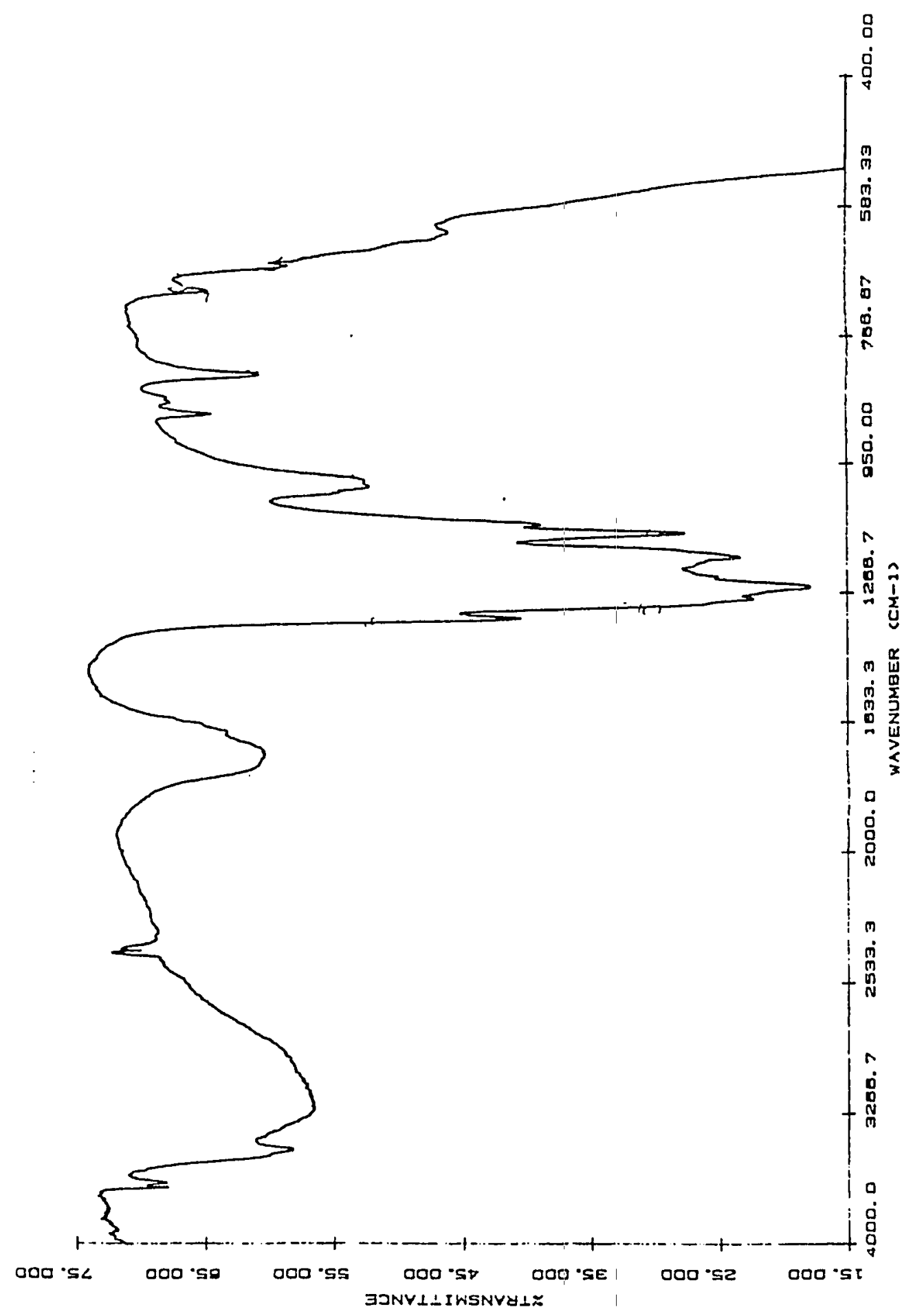

Figure 5. Infrared spectrum of CF2(OCF2CF2SO3H) 2 (VI). 


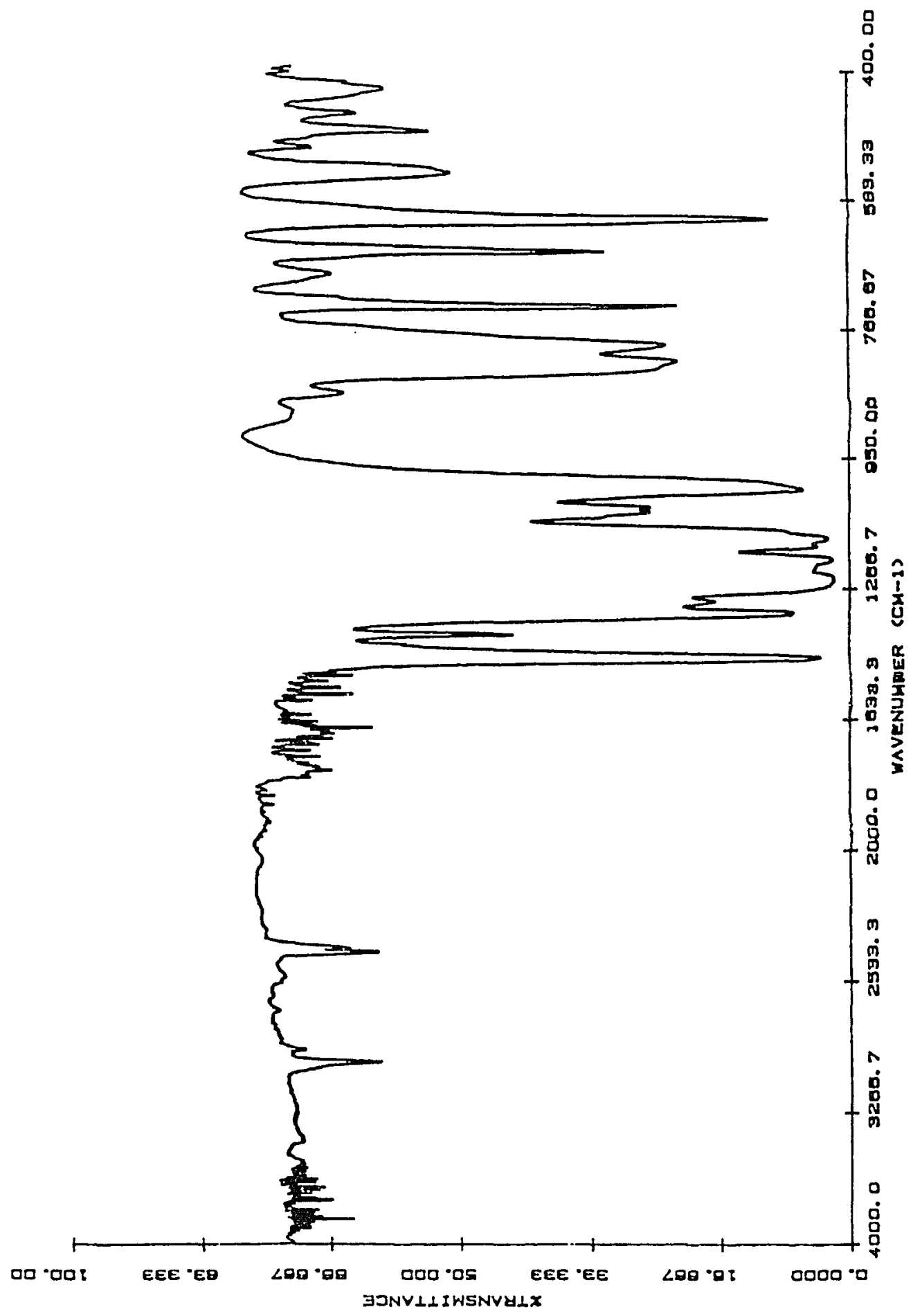

Fiqure 6. Infrared spectrum of $\mathrm{FC}(\mathrm{CF} 3) \mathrm{OCH} 2 \mathrm{CH}_{2} \mathrm{OCF} 2 \mathrm{CF}_{2} \mathrm{SO}_{2} \mathrm{~F}$ (VII). 


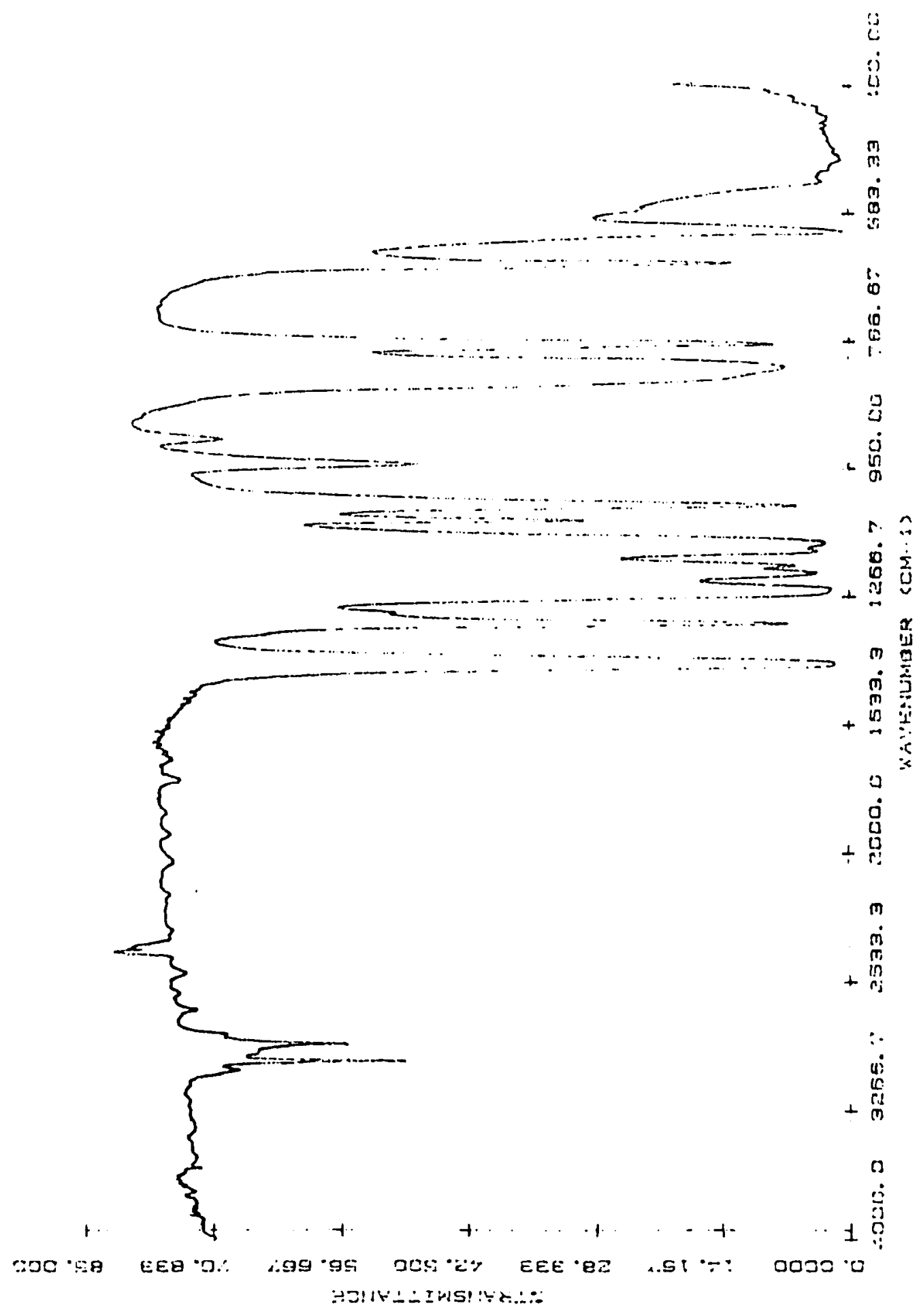

Figure 7. Infrared spectrum of CH3OCF2CF2SO2F (IIX). 


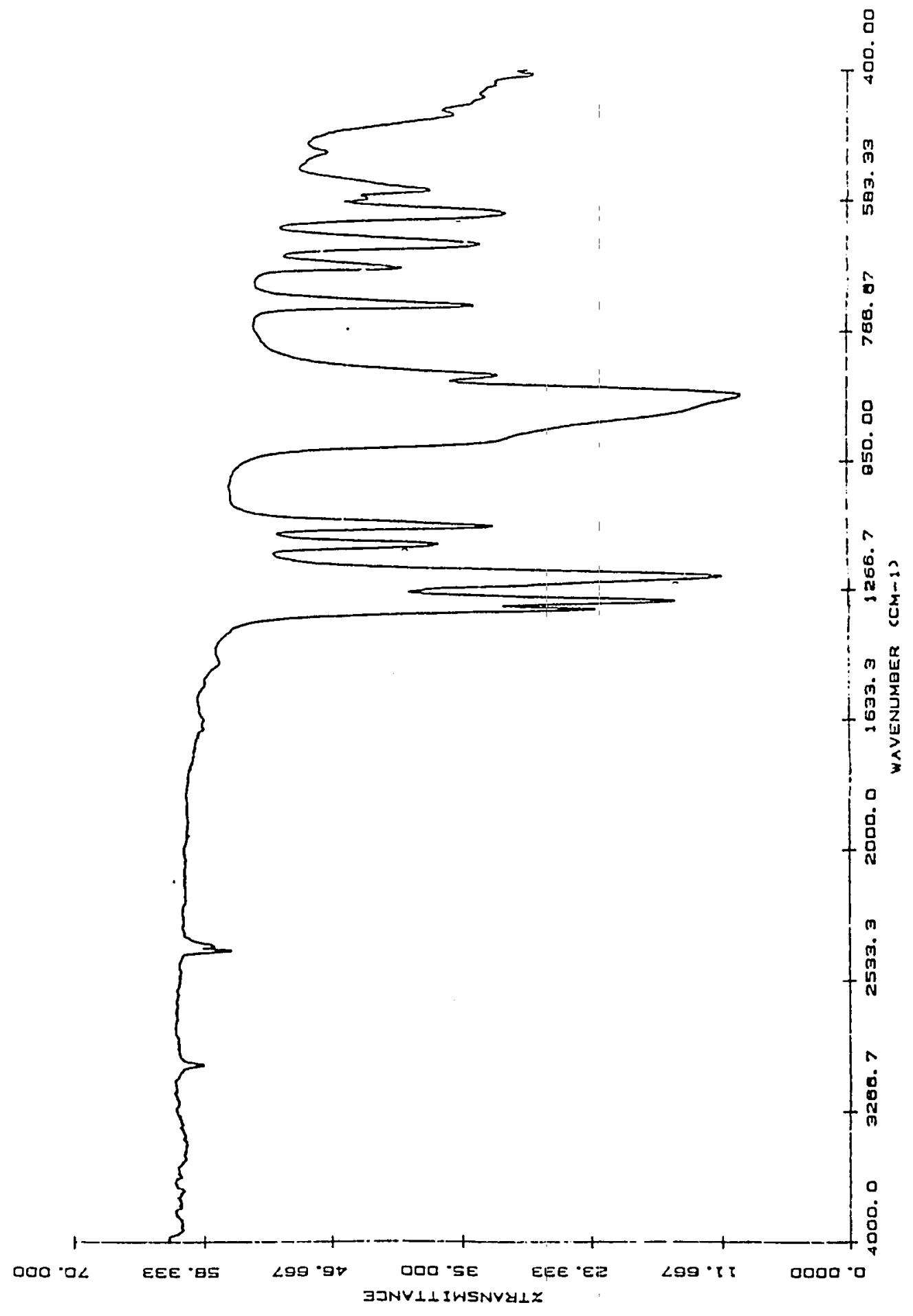

Figure 8. Infrared spectrum of SF5CHFSO3Li (IX). 


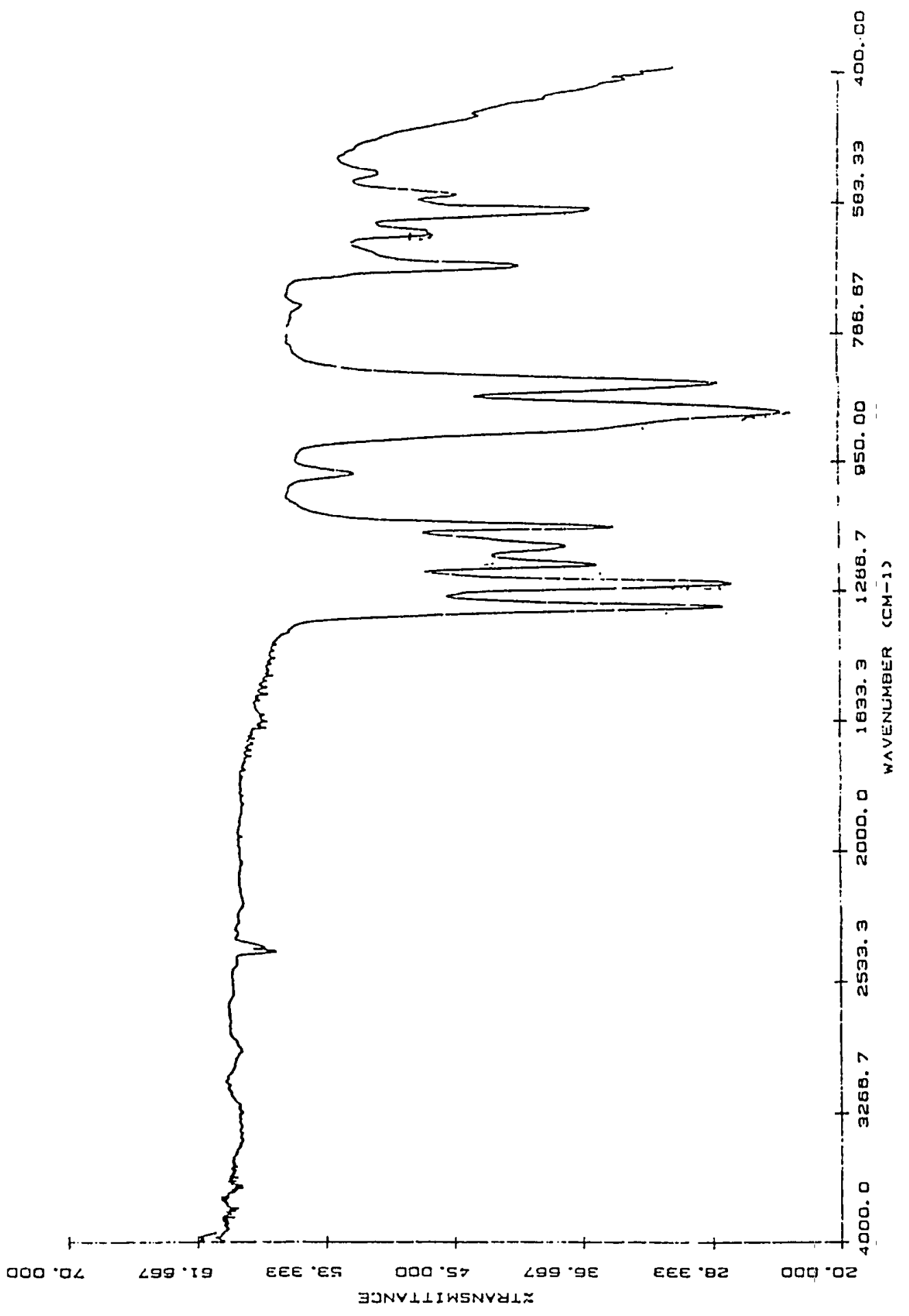

Figure 9. Infrared spectrum of SF5CF2SO3Li (X). 


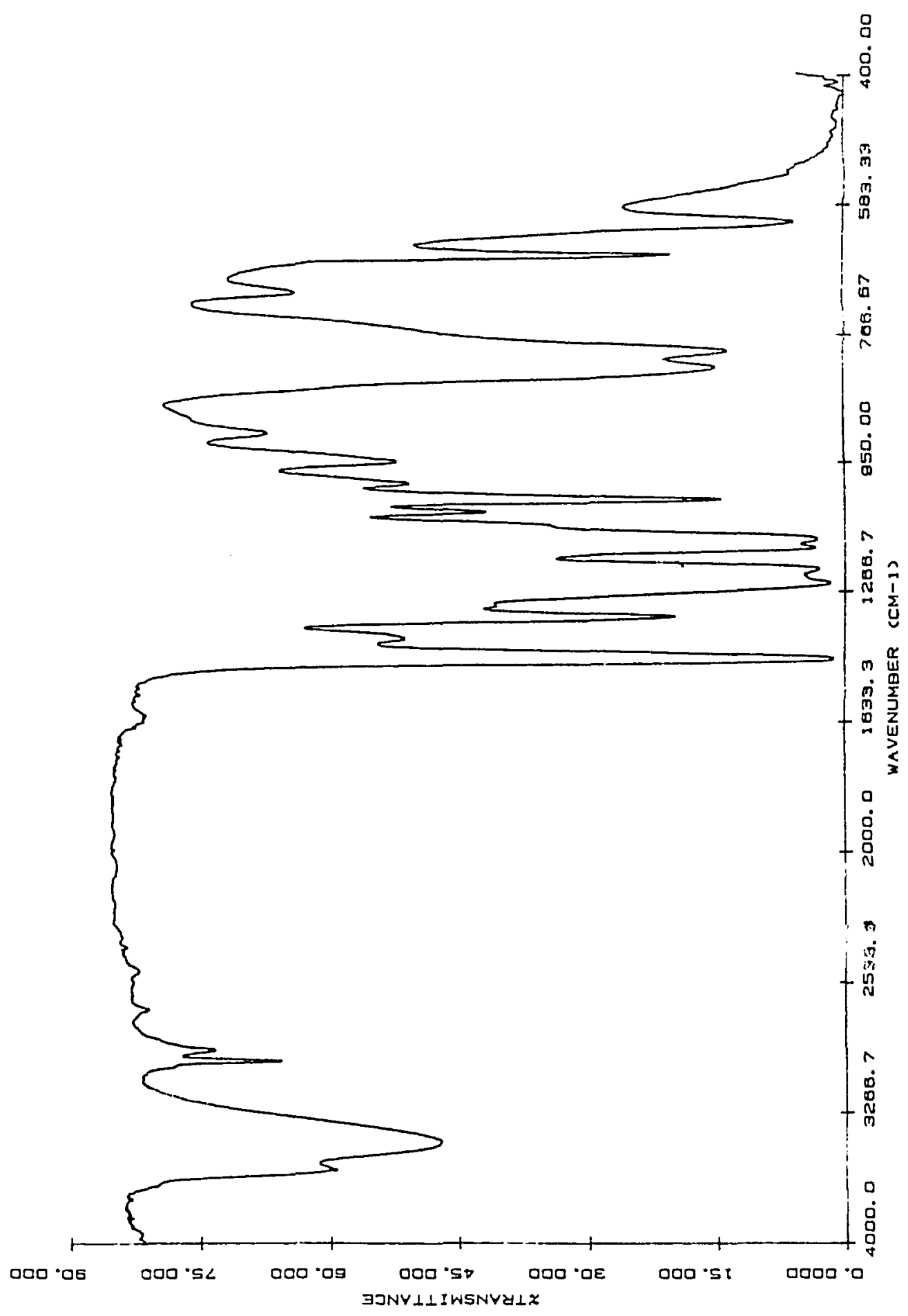

Figure 10. Infrared spectrum of $\mathrm{ClCH} 2 \mathrm{CH}(\mathrm{OH}) \mathrm{CH} 2 \mathrm{OCF} 2 \mathrm{CF} 2 \mathrm{SO} 2 \mathrm{~F}$ (XII). 


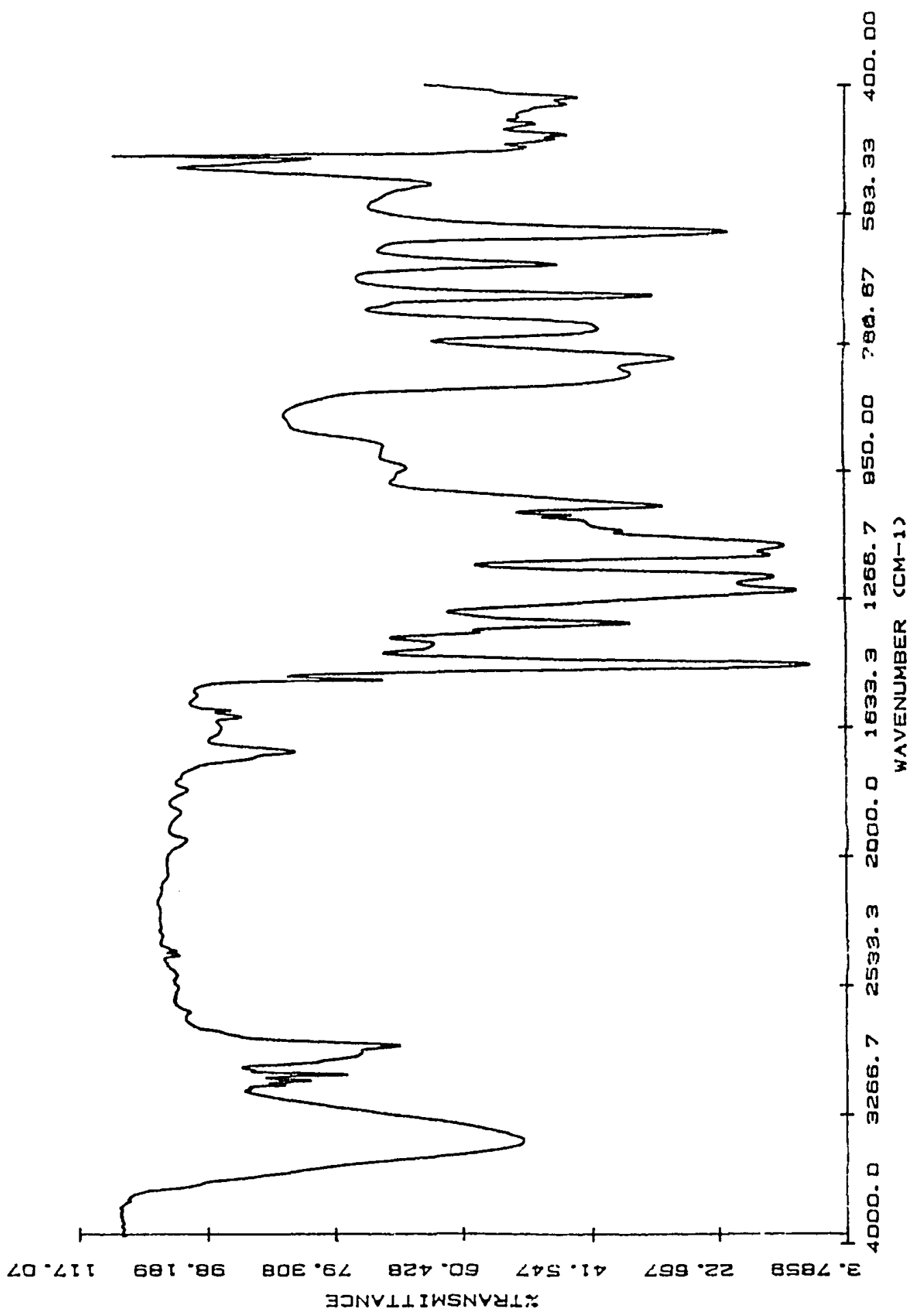

Figure 11. Infrared spectrum of product mixture of $\mathrm{HOCH} 2 \mathrm{CH}(\mathrm{OCH} 2 \mathrm{C}$. H5) OCF2CF2SO2F (XIII) and $\mathrm{C} 6 \mathrm{H} 5 \mathrm{CH} 2 \mathrm{CH}(\mathrm{OH}) \mathrm{CH} 2 \mathrm{OCF} 2 \mathrm{CF} 2 \mathrm{SO} 2 \mathrm{~F}$ (XIV). 


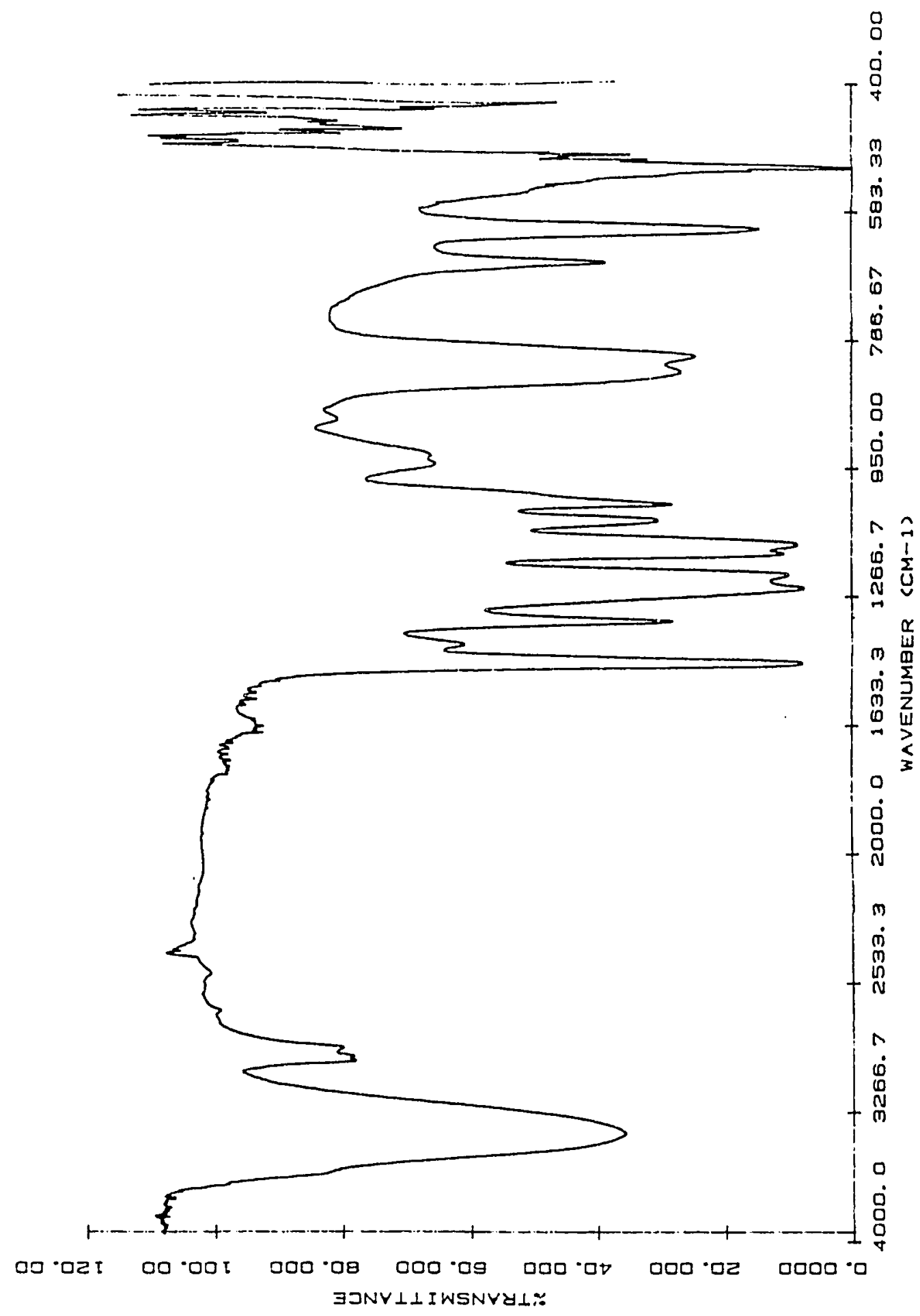

Figure 12. Infrared spectrum of $\mathrm{HOCH} 2 \mathrm{CH}(\mathrm{OH}) \mathrm{CH} 2 \mathrm{OCF} 2 \mathrm{CF} 2 \mathrm{SO} 2 \mathrm{~F}$ (XV). 


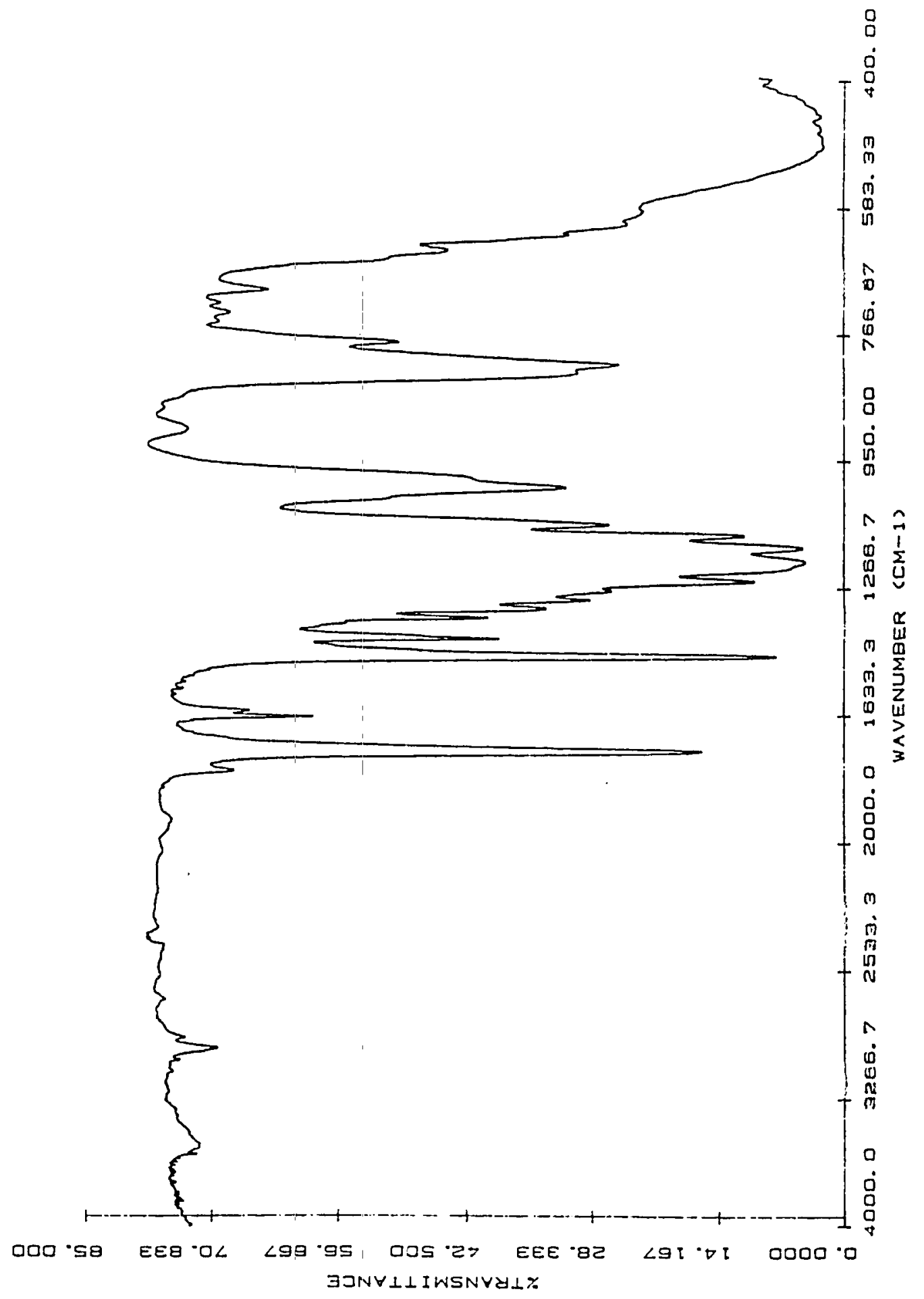

Fiqure 13. Infrared spectrum of acrylate ester $\mathrm{H} 2 \mathrm{C}=\mathrm{CHC}(\mathrm{O}) \mathrm{OCH} 2 \mathrm{CH} 2 \mathrm{CF} 2 \mathrm{CF} 2 \mathrm{OCF} 2 \mathrm{CF} 2 \mathrm{SO} 2 \mathrm{~F}$ (XVI). 


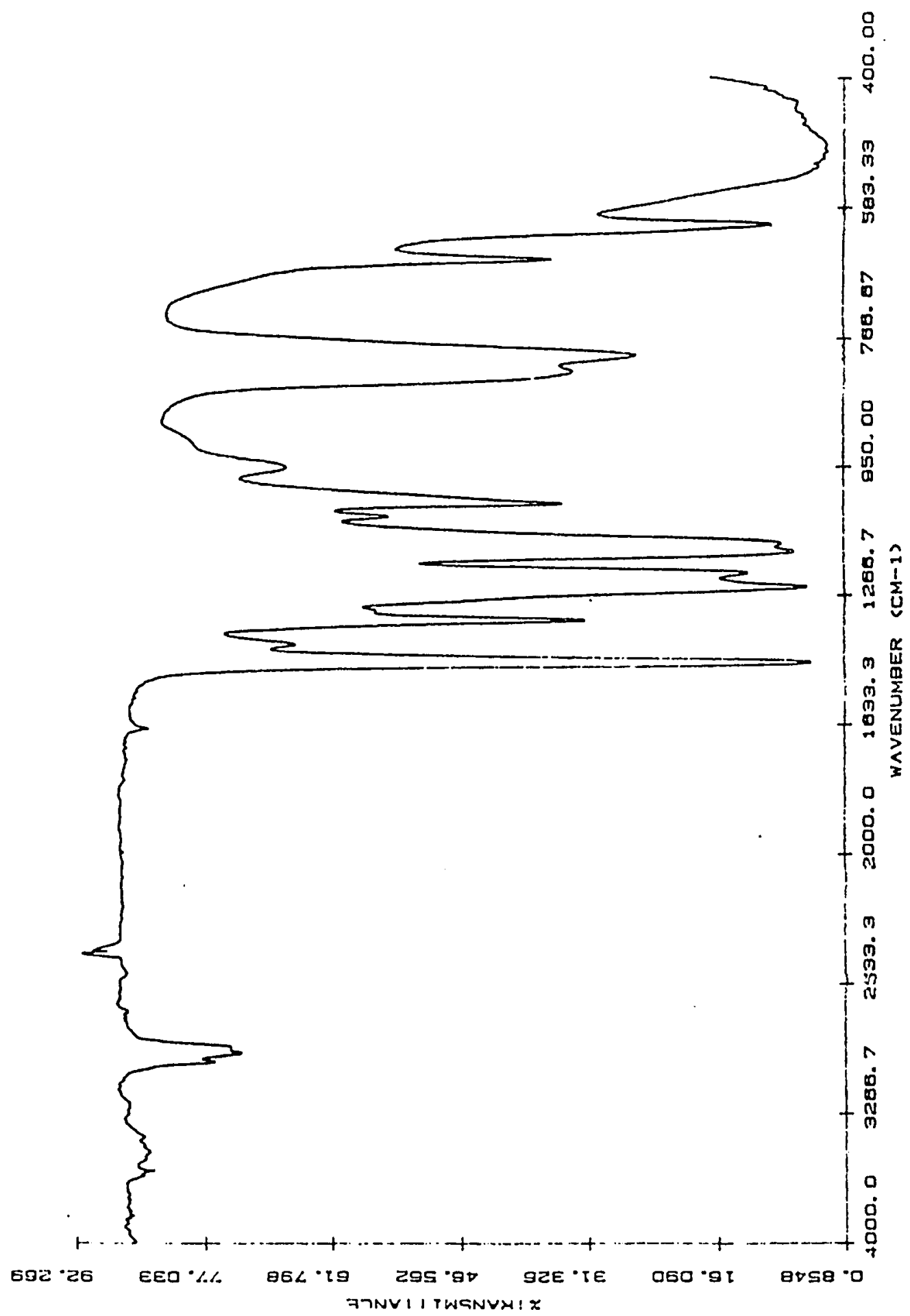

Figure 14. Infrared spectrum of epoxide homopolymer [-OCH2CH $\left.\left(\mathrm{CH}_{2} \mathrm{OCF} 2 \mathrm{CF}_{2} \mathrm{SO} 2 \mathrm{~F}\right)-\right]$ (XVII). 


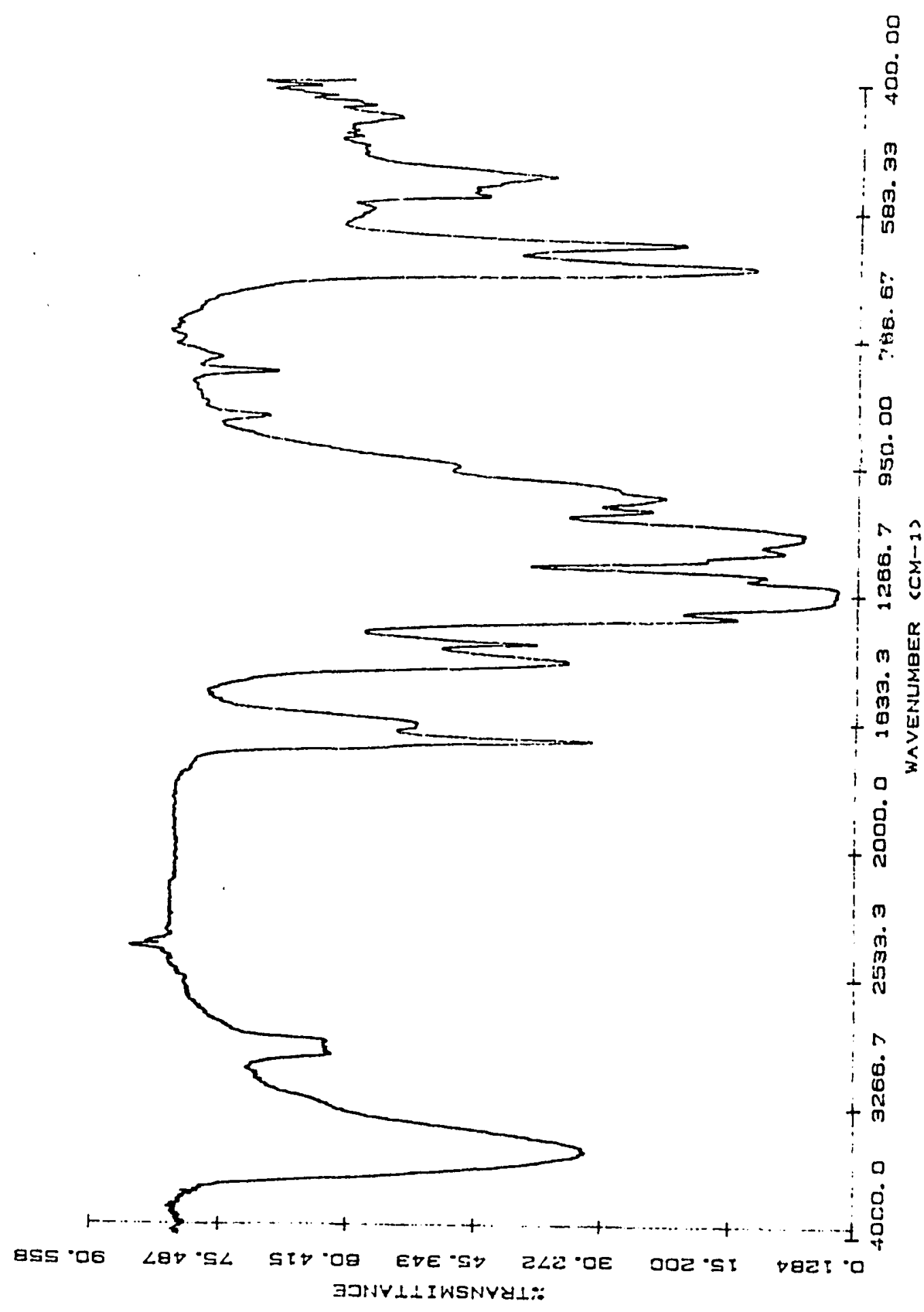

Fiqure 15. Infrared spectrum of polymeric sulfonate salt [-OCH $2 \mathrm{CH}(\mathrm{CH} 2 \mathrm{OCF} 2 \mathrm{CF} 2 \mathrm{SO} 3 \mathrm{Na})-]$ (XIIX). 


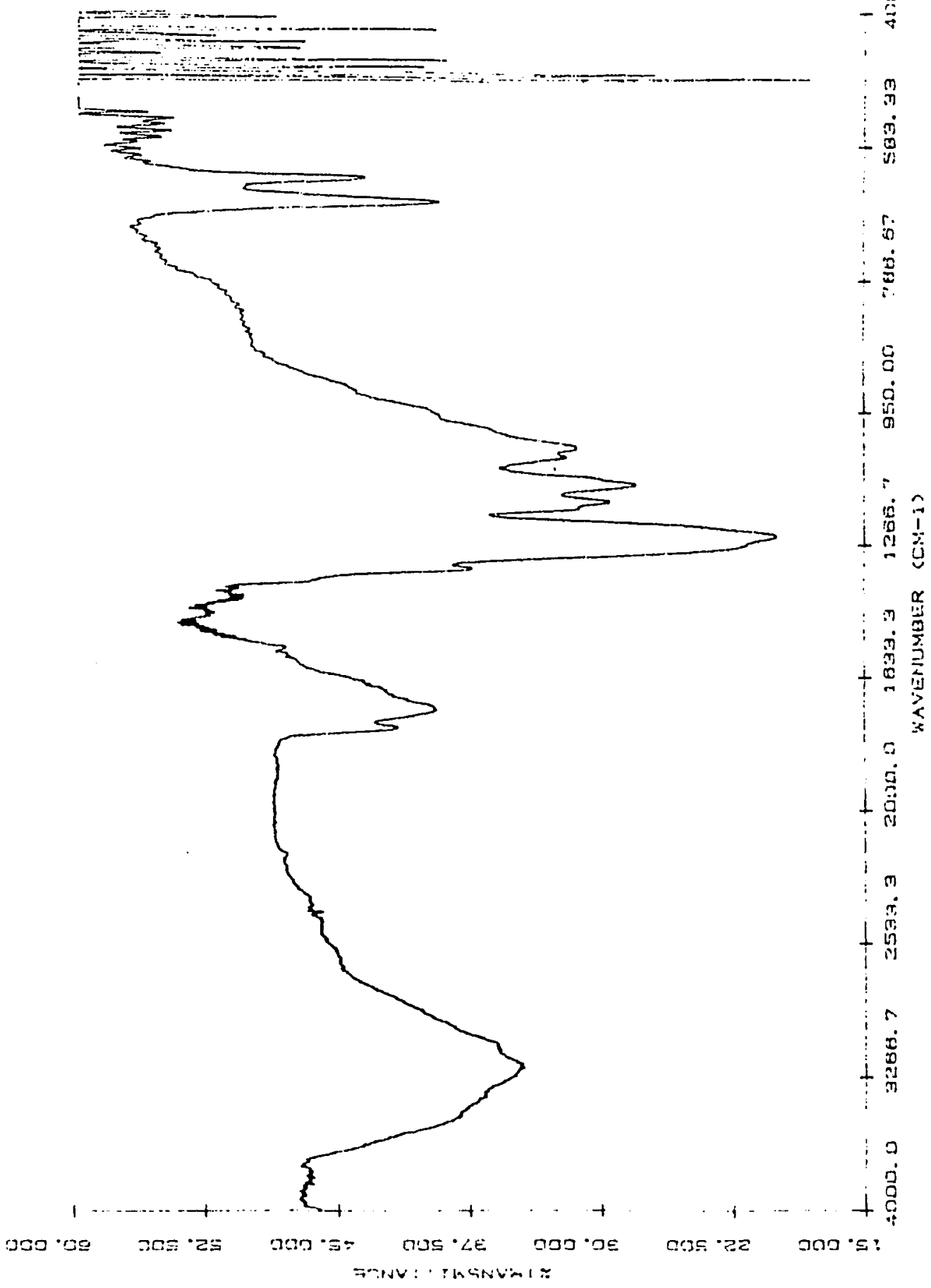

Figure 16. Infrared spectrum of polymeric sulfonic acid [-OCH $\left.2 \mathrm{CH}\left(\mathrm{CH}_{2} \mathrm{OCF} 2 \mathrm{CF}_{2} \mathrm{SO}_{3} \mathrm{H}\right)-\right]$ (XIX). 


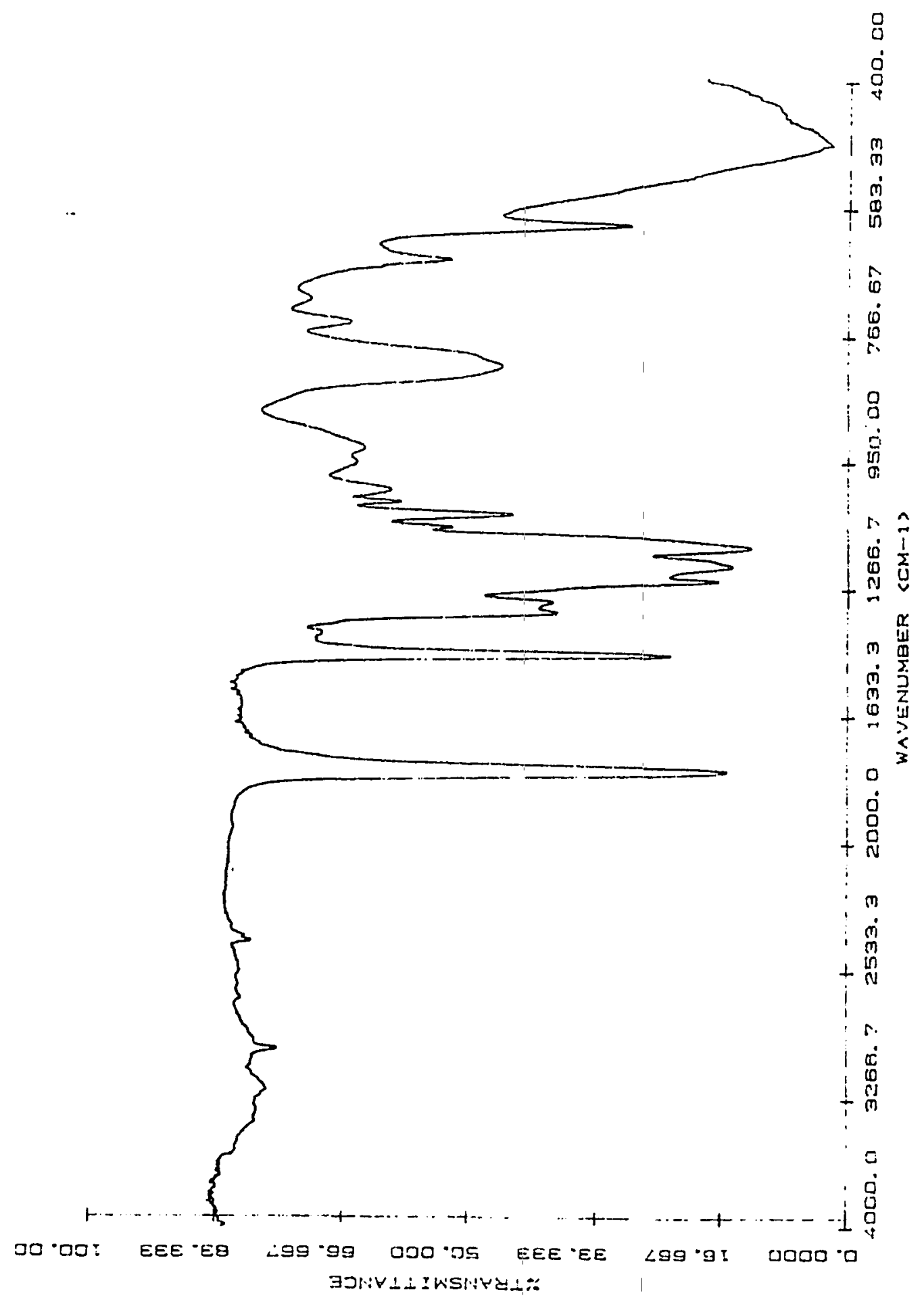

Figure 17. Infrared spectrum of polyester [-C (O) CF2CF2CF2C (O) $\left.\mathrm{CH}_{2} \mathrm{CH}\left(\mathrm{CH}_{2} \mathrm{OCF} 2 \mathrm{CF}_{2} \mathrm{SO}_{2} \mathrm{~F}\right) \mathrm{O}-\right]$ (XXI). 


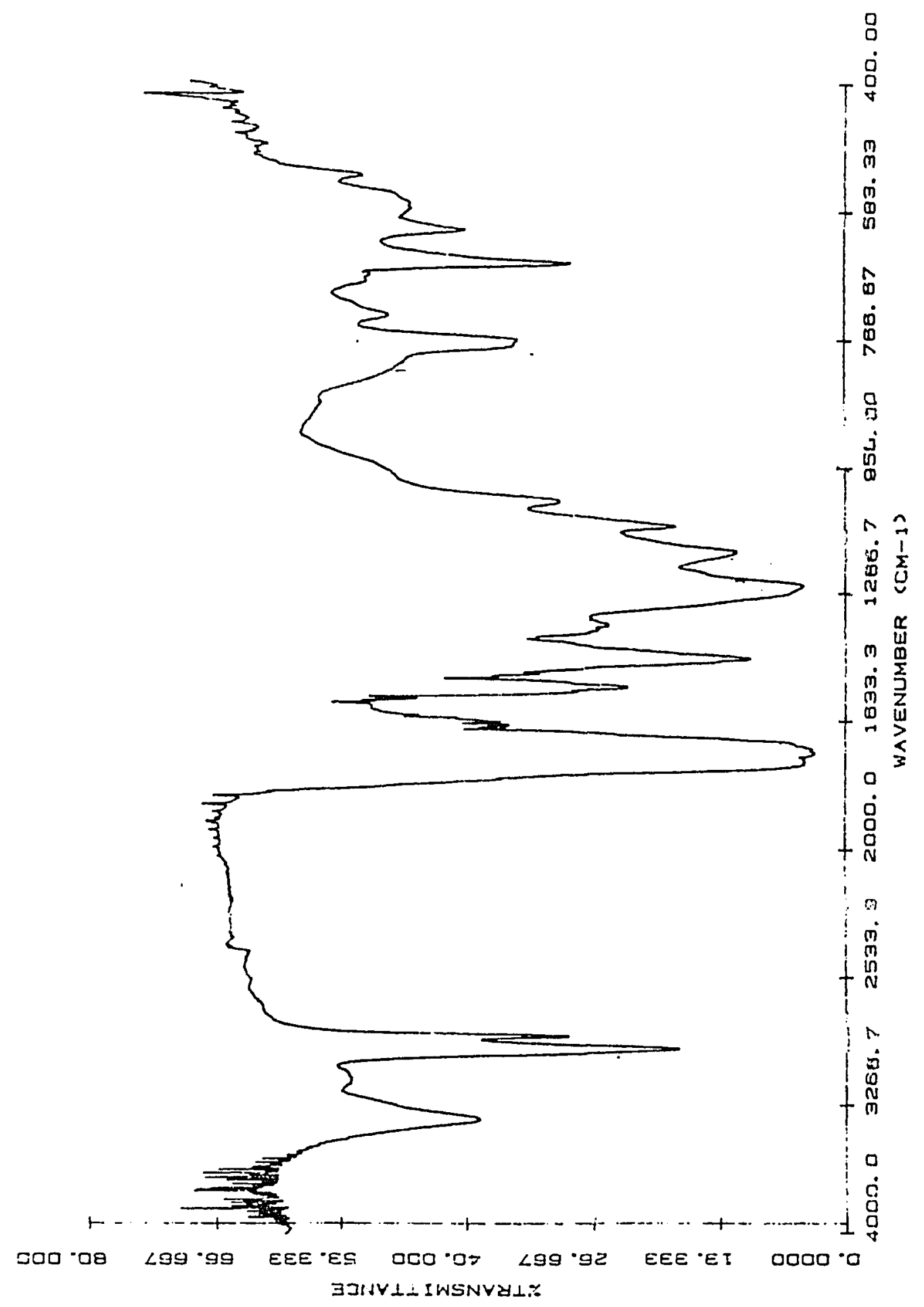

Fiqure 18. Infrared spectrum of $\mathrm{HOCH} 2 \mathrm{CH}(\mathrm{OH}) \mathrm{CH} 2 \mathrm{OCF} 2 \mathrm{CF} 2 \mathrm{SO} 2 \mathrm{~F}$ and $\mathrm{O}=\mathrm{C}=\mathrm{NCH} 2 \mathrm{CH} 2 \mathrm{CH} 2 \mathrm{CH} 2 \mathrm{CH} 2 \mathrm{CH} 2 \mathrm{~N}=\mathrm{C}=\mathrm{O}$ urethane polymer (XXII). 


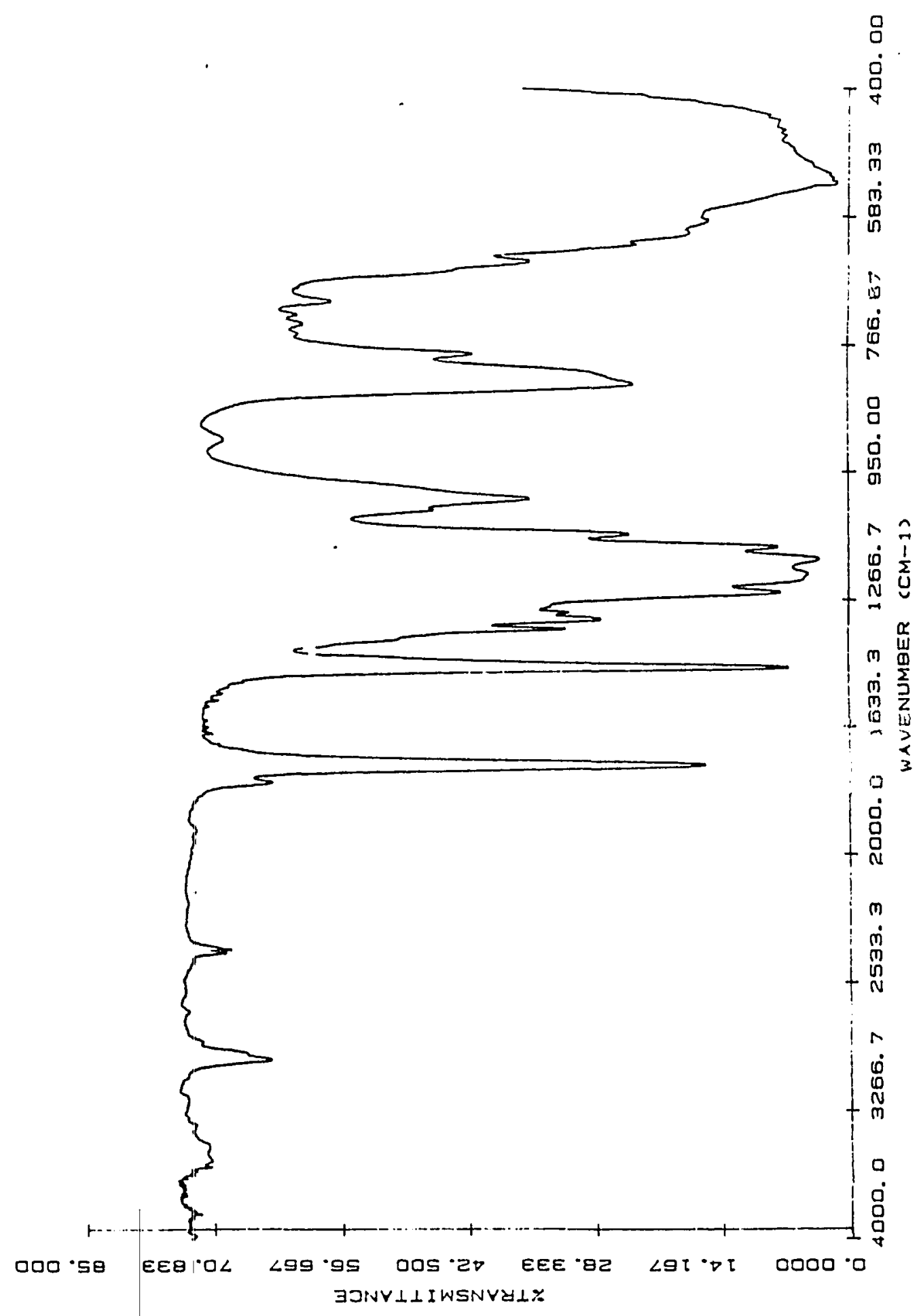

Figure 19. Infrared spectrum of polyacrylate $[-\mathrm{H} 2 \mathrm{C}-\mathrm{CH}(\mathrm{C}(\mathrm{O}) \mathrm{OCH} 2 \mathrm{CH} 2 \mathrm{CF} 2 \mathrm{CF} 2 \mathrm{OCF} 2 \mathrm{CF} 2 \mathrm{SO} 2 \mathrm{~F})-]$ (XXIII). 